\title{
INDIAN SUFISM SINCE THE SEVENTEENTH CENTURY
}

Sufism is often regarded as standing mystically aloof from its wider cultural settings. By turning this perspective on its head, Indian Sufism since the Seventeenth Century reveals the politics and poetry of Indian Sufism through the study of Islamic sainthood in the midst of a cosmopolitan Indian society comprising migrants, soldiers, litterateurs and princes.

Placing the mystical traditions of Indian Islam within their cultural contexts, the study focuses on the shrines of four Sufi saints in the neglected Deccan region and their changing roles under the rule of the Mughals, the Nizams of Haydarabad and, after 1947, the Indian nation. Of particular interest is the book's focus on religion in princely Haydarabad, examining the vibrant intellectual and cultural history of this independent state. However, close attention is also paid to the effects of British colonialism on Sufi individuals and institutions in India. Against these settings, the place of Sufis and their followers in the Indo-Persian and Urdu literary traditions is analysed, showing a popular religious tradition supported by a literature no less than an architecture of sainthood. In this way, an overview of the main developments of devotional Islam in South Asia over the past three centuries is presented from a regional perspective.

Indian Sufism since the Seventeenth Century is essential reading for scholars with interests in Sufism, Islam, India and cultural studies.

Nile Green is Milburn Research Fellow at Lady Margaret Hall, Oxford and Lecturer in South Asian Studies at Manchester University. His wide-ranging research interests focus on Sufism and the history and ethnography of Islam in South Asia, Iran and Afghanistan. 


\section{ROUTLEDGE SUFI SERIES \\ Series Editor: Ian Richard Netton \\ Professor of Arabic Studies \\ University of Leeds}

The Routledge Sufi Series provides short introductions to a variety of facets of the subject, which are accessible both to the general reader and the student and scholar in the field. Each book will be either a synthesis of existing knowledge or a distinct contribution to, and extension of, knowledge of the particular topic. The two major underlying principles of the Series are sound scholarship and readability.

1 BEYOND FAITH AND INFIDELITY

The Sufi poetry and teaching of Mahmud Shabistari

Leonard Lewisham

2 AL-HALLAJ

Herbert W. Mason

3 RUZBIHAN BAQLI

Mysticism and the rhetoric of sainthood in Persian Sufism

Carl W. Ernst

4 ABDULLAH ANSARI OF HERAT

An early Sufi master

A.G. Ravan Farhadi

5 THE CONCEPT OF SAINTHOOD IN EARLY

ISLAMIC MYSTICISM

Bernd Radtke and John O'Kane

6 SUHRAWARDI AND THE SCHOOL OF ILLUMINATION

Mebdi Amin Razavi

7 PERSIAN SUFI POETRY

An introduction to the mystical use of classical poems

J.T.P. de Bruijn 
8 AZIZ NASAFI

Lloyd Ridgeon

9 SUFIS AND ANTI-SUFIS

The defence, rethinking and rejection of Sufism in the modern world

Elizabeth Sirriyeh

10 REVELATION, INTELLECTUAL INTUITION AND REASON

IN THE PHILOSOPHY OF MULLA SADRA

An analysis of the al-hikmah al-'arshiyyah

Zailan Moris

11 DIVINE LOVE IN ISLAMIC MYSTICISM

The teachings of al-Ghâzalî and al-Dabbâgh

Binyamin Abrabamov

12 STRIVING FOR DIVINE UNION

Spiritual exercises for Suhrawardi Sufis

Qamar-ul Huda

13 A PSYCHOLOGY OF EARLY SUFI SAMA

Listening and altered states

Kenneth S. Avery

14 MUSLIM SAINTS OF SOUTH ASIA

The eleventh to fifteenth centuries

Anna Suvorova

15 SUFI VISIONARY OF OTTOMAN DAMASCUS

'Abd al-Ghani al-Nabulusi, 1641-1731

Elizabeth Sirriyeh

16 SUFI RITUAL

The parallel universe

Ian Richard Netton

17 EARLY MYSTICS IN TURKISH LITERATURE

Mehmed Fuad Koprulu

Translated, edited and with an Introduction by Gary Leiser E Robert Dankoff

18 INDIAN SUFISM SINCE THE SEVENTEENTH CENTURY

Saints, books and empires in the Muslim Deccan

Nile Green 



\section{INDIAN SUFISM SINCE THE SEVENTEENTH CENTURY}

Saints, books and empires in the Muslim Deccan

Nile Green

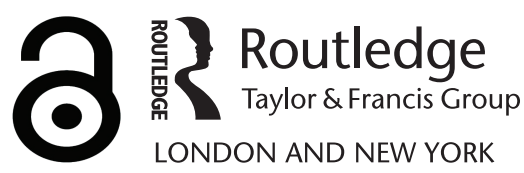


First published 2006

by Routledge

Published 2017 by Routledge

2 Park Square, Milton Park, Abingdon, Oxon OX14 4RN

711 Third Avenue, New York, NY 10017, USA

Routledge is an imprint of the Taylor E Francis Group, an informa business

Copyright (C) 2006 Nile Green

Typeset in Garamond by

Newgen Imaging Systems (P) Ltd, Chennai, India

The Open Access version of this book, available at www.tandfebooks.com, has been made available under a Creative Commons Attribution-Non Commercial-No Derivatives 4.0 license.

British Library Cataloguing in Publication Data A catalogue record for this book is available from the British Library

Library of Congress Cataloging in Publication Data A catalog record for this book has been requested

ISBN13: 978-0-415-39040-8 (hbk) 
FOR MY PARENTS, GEOFFREY AND OLIVIA GREEN 



\section{CONTENTS}

List of figures

Preface xiii

Acknowledgements xvii

A note on transliteration and names $\quad \mathrm{xxi}$

List of abbreviations xxiii

Map $1 \quad$ xxv

1 Muslim mystics in an age of empire: the Sufis of Awrangabad

2 The poetry and politics of sainthood in a Mughal successor state

3 The Sufis in the shadow of a new empire 82

4 Saints, rebels and revivalists 103

5 The Awrangabad saints in the new India 134

Conclusions 158

Glossary $\quad 162$

Notes 164

Bibliography 186

Index 200 



\section{FIGURES}

1.1 The mausoleum of Awrangzeb's wife (Bibi ka Maqbara) in Awrangabad

1.2 Throne (masnad) of Nizām al-Mulk at Nawkhanda Palace, Awrangabad

2.1 Panchakkī, the shrine of Shāh Musāfir and Shāh Palangpōsh 58

2.2 The tombs of Shāh Musāfir and Shāh Palangpōsh 60

3.1 Shrine attendant (khādim) before the tomb of Shāh Musāfir 92

4.1 The mausoleum of Nizām al-dīn Awrangābādī 107

4.2 A Sufi pilgrim at the shrine of Nizām al-dīn Awrangābādī 114

5.1 Miniature painting of Shāh Nūr at the math of Mānpūrī in Dawlatabad

5.2 Sufi musicians singing qawwāt̄̄ at Khuldabad 



\section{PREFACE}

...a qalandar without equal, an enlightened dervish, a griffin on Mount Qaf, a holy hawk in the space of divine intimacy, he was always busy in the remembrance of the Truth and is among the fakirs and great ones of the Sufi path. ${ }^{1}$

The mystical Muslim tradition known in the West as Sufism was intimately associated with the cult of the saints (awliy $\bar{a}$ ) from early in its history. ${ }^{2}$ Yet the dichotomy once drawn by an earlier generation of scholars between an 'authentic' sophisticated and textual Sufi tradition and a 'decadent' popular and non-literate tradition of the veneration of living or dead saints has done much to obscure the actual nature of Sufis and Sufism in the different societies of the past. ${ }^{3}$ In many ways this problem was engendered by an over-reliance upon written materials (especially poetical and doctrinal works) without reference to their wider contexts. But this model of Sufism as primarily (or even ideally) the pursuit of the erudite hermit rather than a shared and collective phenomenon rooted as much in social as in individual dispensations has proven to be as influential as it is distorting. For if 'real' Sufism was this learned and didactic quest for divine union, then any persons and practices linking Sufism with less elevated and more worldly concerns needed necessarily to be marginalized as peripheral or 'inauthentic'. Over time, this individualist model led to a widening of the separation between Sufism and its cultural contexts, for in practice it was often these very 'debased' saintly practices that formed the bonds tying Sufis and their multifarious practices to their wider social environments. While little work has been done on saintly or other shrine cults in the early centuries of Islam, it may have been partly in the face of widespread competition for saintly status and confusion regarding its precise criteria that such early Sufi writers as Tirmidhī (d. c.295/908) wrote their handbooks of the stages of the path to sainthood (walayat). ${ }^{4}$ Both the cultural geography and the religious forms of the Near East prior to the rise of Islam were characterized by an abundance of saintly cults of one kind or another. ${ }^{5}$ However sensitive to the 'originality' and integrity of Islam, the idea of a complete hiatus of such religious activity with the rise of Islam that was only to be followed a few centuries later by a kind of saintly re-awakening runs contrary to the developmental history of religious traditions as extended cultural phenomena as opposed to abstracted sets of limited theological ideals. While sudden religious 
transformations may typify the life of prophets, they rarely characterize the life of whole peoples. While scholars once saw such early texts as those of Tirmidhī as the proof of a chronologically earlier tradition of 'authentic' mystic pursuits, it seems possible that the presence of miracle-working holy men already formed the wider religious context within which such early theorists were writing. At what point Muslim intellectuals chose to dignify such figures in writing, and describe them through the vocabulary of Sufism (tasawwuf), is another matter. Yet Tirmidhï's own tomb soon became the focus of a robust saintly tradition. And by the turn of the eleventh century other early Sufi writers like Sulamī (d. 412/1021) and Hujwīrī (d. 465/1072) were more candidly describing the shrines of earlier Sufis and pilgrimages to them and doing so, moreover, in terms of a normative practice.

With a few notable exceptions, until the 1990s the scholarly marginalization of Sufi shrines and the variety of activities surrounding them continued, phenomena which traditional scholarship had regarded as related only tenuously to Sufism if related to it at all. Yet despite the concentration of many scholars working earlier in the twentieth century upon individual 'mystical' writers as exemplars of the Sufi path, there were relatively few among these great literary luminaries who were not themselves the centre of shrine cults in their own right. While a tradition of singlemindedly textual scholarship almost entirely divorced Sufis and their literary products from the world of shrines and saint veneration, the two were in practice closely linked if not inseparable, with a given Sufi's literary production itself often forming an important criterion in the saint-making process. In regions such as Afghanistan to this day, the connection between poetic inspiration and sainthood remains unbroken. Here is Islam in its fully human trappings, standing firm as both Muslims and nonMuslims attempt to whittle it away into a modernist equation of doctrine and regulation. The roles played by Sufis as litterateurs and seekers of divine transcendence were only two aspects of much more complex personae, with politics, miracle-working and even soldiering forming other roles associated with and often expected of Sufis. Hagiographic no less than ethnographic material thus show Sufis reflecting many of the roles associated with the traditional sabios ('wise ones') of the Andalusian countryside, whose special possession of gracia ('grace') clearly echoes the association of baraka ('blessing, life-force, grace') with charismatic Sufi holy men. ${ }^{6}$ Embodied in the human social world through the presence of its representatives, Sufism was a far more worldly and vital force than a mere inventory of abstract beliefs would suggest.

It is only when the wide range of activities that Sufis performed is acknowledged that the close links between the living Sufi and the dead saint become apparent. For while the scene of pilgrims begging for help with their daily material needs at the shrines of Muslim saints can seem a world away from the image of the Sufi shut definitively away from the world in rapt meditation, the gap between shrine and Sufi seems less unbridgeable if the same Sufi is known to have spent as much time administering the worldly affairs of his clients as with his more solitary and 'mystic' pursuits. Such misconceptions often seem to be the result of a narrow definition of mysticism adopted from intellectualist European milieux, and in more recent times from an Anglo-American neglect of social theory. But in practice, 
saint and Sufi were often overlapping categories, each adapting and informing the other. In this way, the literary imagining of the characters and careers of earlier Sufi saints helped to shape the lives of living Sufis through the widespread reading of hagiographies, while the writing of hagiographies of past saints was in turn informed by the living concerns of the Sufis by and among whom they were written. A sense of the constant interplay between the lived and the written worlds of the Sufis is therefore essential to understanding Sufism both as transcendent ideal and as social reality.

Traced in the following chapters is the evolution and subsequent history of a loosely linked local pantheon of Muslim saints in India. The regional focus for the study is the southern part of India known as the Deccan, whose rich Muslim legacy reaches back to at least the thirteenth century. The specific focus for the study is the city of Awrangabad, whose history from its seventeenth- and eighteenth-century heyday under the Mughal and Āsaf Jāh rulers (the latter better known as the Nizāms of Haydarabad) through to modern times forms the context against which the history of the city's Sufi saints is examined. Particular attention is given to the roles played in the formation of Muslim sainthood by written narrative and sacred space, both in terms of a specific built environment of shrines and a wider cultural geography. Yet such writing and architecture both depended on the patronage born from a specific social order. The transformation from a living holy man to an immortal saint is shown to be heavily dependent upon the construction of a saintly shrine and at all later stages closely connected to its maintenance. In addition to the actual mausoleum of the saint, such shrine complexes included a khanaqah, mosque and residence for the living representative of the saint known as the sajjäda nashin ('he who sits on the prayer rug'). As both lodges for the spiritual retreat of dervishes and pilgrimage-centres for wider clienteles, amid their settings in the human geography of urban or sub-urban life, the shrines reveal the interdependence of Sufism and the cult of the saints along with their common ties to the wider cultural history of their communities.

As a territory newly conquered by the Mughal rulers of North India in a region already possessing a rich Muslim heritage of its own, during the first century after its re-foundation in 1092/1681 Awrangabad and its hinterland was particularly well-placed to exhibit the cosmopolitan diversity of Indo-Muslim life. Looking out from Awrangabad the book charts the social and cultural fissures of Indo-Muslim history from the zenith of Mughal power through the evolution of the Muslim successor state of Haydarabad to the consequences of colonialism for the institutional and intellectual world of devotional Islam. Finally we assess the state of Awrangabad's saintly traditions after the loss of its officially Muslim persona with the collapse of Haydarabad state after Indian independence in 1947. Re-asserting the inevitable politics of spirituality, we show how the careers and indeed characters of the Sufi saints evolved in reflection of the changing fortunes of their clients. Against this background of intractable historical change, memory and its local mechanisms are seen to be at the heart of the cultural functions of the saints and of the literature, legends and monuments that surround them. By mapping the contours of these changes in the social and the written worlds of the Sufis, this study accentuates the diversity and mutability of Islamic tradition through an investigation into the cultural history of one of its more neglected regions. 



\section{ACKNOWLEDGEMENTS}

The research and writing of this book would not have been possible without the financial and other forms of support I have received from a number of academic institutions and learned societies. I would like to express my special gratitude to the Faculty of Theology at Oxford University for electing me to the Gordon Milburn Junior Research Fellowship and to the Principal and Fellows of Lady Margaret Hall for making my years in Oxford so comfortable and congenial. I would also like to acknowledge the Trustees of the Ouseley Memorial Trust at the University of London for granting me the Sir William Ouseley Memorial Scholarship for the doctoral work at the School of Oriental and African Studies from which this monograph developed. I would also like to thank my colleagues in the department of Religions and Theology at Manchester University for their support as I brought this project to completion. My earlier studies of Sufism, and of Persian in particular, were enabled several years earlier by a studentship from the British Academy to study at Pembroke College, Cambridge.

The numerous field trips from which my research developed were also partly funded by a number of bodies. An early field trip to Iran in 1996 was supported by the British Institute of Persian Studies; later field trips to India were supported by the Ouseley Memorial Trust, the Society for South Asian Studies, the Faculty of Theology at Oxford University and the Fellows Travel Fund of Lady Margaret Hall, Oxford. I was also able to collect some final material while researching another project in Hyderabad supported by a Small Research Grant from the British Academy in 2005. In this connection I would also like to thank Brian Wood and Carl Welsby, formerly of Travelbag Adventures, for turning a blind eye while I pursued my intellectual interests on the pretext of running dozens of tours for them during the 1990s in India, Iran and elsewhere in the Middle East. I am also grateful to the librarians at the School of Oriental and African Studies, Cambridge University Library, the Bodleian Library and Indian Institute, Oxford, the archives of the Church Missionary Society at Birmingham University Library, the Bibliothek der Asien-Afrika-Institut der Universität Hamburg, the Salar Jung Library, Hyderabad, and to Roberta Staples at Lady Margaret Hall, Oxford and Nigel James of the map room at the Bodleian Library.

Revised sections from my articles 'Geography, Empire and Sainthood in the Eighteenth Century Muslim Deccan', Bulletin of the School of Oriental and African 
Studies, 67, 2 (2004) and 'Stories of Saints and Sultans: Re-membering History at the Sufi Shrines of Aurangabad', Modern Asian Studies, 38, 2 (2004) are reprinted with permission in Chapters 1 and 5 respectively from the Copyright holders, Cambridge University Press. The map was produced using Collins Bartholomew Ltd 2005 digital data with permission of HarperCollins Publishers.

I would also like to express an evident and lasting debt to my teachers in Sufi, Persian and Indo-Muslim studies, namely Julian Baldick, the late John Cooper and particularly Christopher Shackle. In Aurangabad, my studies in Urdu were guided by the latter-day guardian of the city's learned and cosmopolitan traditions, the poet Bashar Nawaz. As the repercussions of the September 11 attacks on America unfolded, the year I spent working as Research Assistant (or portaborse, as certain friends preferred) to Sir Jack Goody was inspirational on a variety of levels. I would also like to thank the following scholars for their support, advice and conversation: Francis Robinson, Ian Richard Netton, Simon Digby, Omar Khalidi, Bruce Wannell, Jürgen Wasim Frembgen, George Michell, Helen Philon, Alessandro Monsutti, Michel Boivin, Scott Kugle, David Washbrook, Sanjay Subrahmanyam, William Dalrymple, Farhan Nizami, Stuart Blackburn, Crispin Branfoot and Jagdish Mittal. I would like to record my special thanks to Carl Ernst for sending me xerox copies of manuscripts of works by Gul Muhammad Ahmadpuri and Khaksar Sabzawari. Fatima Nejadveisi was generous enough to send me a whole series of books from Iran.

In Aurangabad and elsewhere in the Deccan, I was helped (and occasionally hindered) by a variety of individuals. Along with my dear friend and ustad Bashar Nawaz, I would like to record my special gratitude to Seyyid Hasan, Mirza Agha Beg and Mohammed Abd al-Hayy for their help in supplying copies of manuscript and rare printed works. Prof. Sheikh Ramzan was particularly helpful in supplying me with copies of administrative documents that he has preserved from Panchakki and for allowing me to consult his $\mathrm{PhD}$ thesis on medieval Aurangabad. At Balapur, I was helped by Syed Zahir ul-Islam Naqshbandi, who supplied me with works related to the tradition of Shah 'Inayat Allah of Balapur. I would also like to record my thanks to the Sheikh family; Dr Mirza Khizr of Babasaheb Ambedkar University; Mrs Rizwana Ateeq Kazi, Taqi Ahmad Naqshbandi, Yusuf Maghrebi and Hafez Aqil Maulana of Panchakki; Dada Pir, Mirza Ibrahim 'Lal' Beg, Mohammed Sharafuddin Siddiqi, Athar Siddiqi, Shihabuddin and Usman Bhai at the shrine of Shah Nur; the late Syed Yaqub Ali and the sajjada nashin of Nizam al-din's shrine, Mohammed Miyan, for his exemplary hospitality; Muinuddin Khan, Seyyid Quddus and Kashifuddin Khan at the shrine of Banne Miyan; Riazuddin Nehri and Muazzam Ali Nehri at the shrine of Shah 'Ali Nehri; Iqbal Ahmed Khan and his wife Kaniza at the shrine of Shah Sokhta Miyan; Seyyid Iqbal Ahmed Shattari at the shrine of Shaykhan Awliya; and Maqsud Ali, Namdev Gopinat Perkar, Khajar and Mahdu Gangathar Jadhar at the math of Manpuri at Daulatabad. Samir Khan, Nurul Husnayn, Rafat Nawaz and Shivaji were also among those who recounted legends of the saints to me. Abdul Rashid Wahdati was magnanimous in inviting me to join hands with the golden chain of the saints.

Mercifully, many dear friends have distracted me during the years in which this book was ruminated, written and revised and I would like to record something of 


\section{ACKNOWLEDGEMENTS}

them too. These were my fellow travellers: the Bermondsey Bohemians, the Cambridge Four and the international buccaneers of the Safinat al-Baraka. Salud!

Final thanks must go to my parents, Geoffrey and Olivia Green. And also to my wife, Nushin Arbabzadah, who via London, Aurangabad, the Cotswolds, Hamburg, Cambridge, Oxford and Moratalla was there through every humble hal wa maqam through which this book passed before reaching its present state. 



\section{A NOTE ON TRANSLITERATION AND NAMES}

The system of transliteration adopted in this work for Arabic, Persian and Urdu words consists of a simplified and somewhat modified form of the Encyclopaedia of Islam system, with qaf rendered as $q$, jim as $j$ and zad as $z$. Underdots and hamza have been omitted. The letters $\bar{o}$ and $\bar{e}$ represent the voicing of the long Indo-Persian vowels and have been used in addition to $\bar{u}$ and $\bar{\imath}$ in accordance with standard usage for Indo-Persian and Urdu transliteration.

With the exception of Mecca and Delhi, place names have been given in transliterated form rather than in accordance with modern spelling (e.g. Haydarabad for Hyderabad, Awrangabad for Aurangabad). However, for simplicity's sake I have omitted diacritical marks. All personal names are fully transliterated, with the exception of the names of Indian rulers who are suitably well known. Except for Chapter 5 (which deals with the period after 1947), the term India should be taken in the premodern geographical sense rather than in reference to the modern state of the same name.

Dates are provided according to both the Islamic (bijrī) and Gregorian calendars. 



\section{ABBREVIATIONS}

\begin{tabular}{|c|c|}
\hline $\bar{A} f t \bar{a} b$ & Tārā Sāhib Qurēshī - Āftāb-e-Dakan \\
\hline$A K$ & Muhammad Ismā 'īl Shāh Qādirī - A'zam al-Karāmāt \\
\hline 'Āmira & Ghulām 'Alī Āzād Bilgrāmī - Khazāna-ye-'Āmira \\
\hline Aqtāb & Rawnaq 'Alī-Rawzat al-Aqtāb \\
\hline$A^{\prime} r \bar{a} s$ & Muhammad Najīb Qādirī Nagawrī - Kitāb-e-A'rās \\
\hline$A S$ & $\begin{array}{l}\text { Kāmgār Khān - Absān al-Shamā'il (Malfüzāt-e-Shāh Nizām al-dīn } \\
\text { Awliyā Awrangābādī) }\end{array}$ \\
\hline $\bar{A} t h \bar{a} r$ & Sayyid Ahmad Khan - Āthār al-Sanād̄̄d \\
\hline Barakāt & $\begin{array}{l}\text { Sayyid Imām al-dīn Naqwī-Tadbkira-ye-Buzurgān-e-Dakan: Barakāt } \\
\text { al-Awliyā }\end{array}$ \\
\hline Fakbriyyat & 'Imād al-Mulk Ghāzī al-dīn Khān - Fakbriyyat al-Nizām \\
\hline Hasan & Sayyid Hasan - Hālāt $\bar{u}$ Zindagī-ye-Nizām al-dīn Awliyā Awrangābāad \\
\hline Kashkül & Shāh Kalīm Allāh Jahānābādī - Kashkūl \\
\hline Khaz & Ghulām Sarwar Lāhawrī - Khazīnat al-Asfiy $\bar{a}$ \\
\hline Maktūbāt & Shāh Kalīm Allāh Jahānābādī - Maktūbāt-e-Kalīmī \\
\hline$M K$ & Ghulām 'Alī Āzād Bilgrāmī - Ma'āthir al-Kirām \\
\hline$M N$ & $\begin{array}{l}\text { Shāh Mahmūd Awrangābādī - Malfūzāt-e-Naqshbandiyya: Hālāt- } \\
\text { e-Hazrat Bābā Shāh Musāfir Sābib }\end{array}$ \\
\hline$M U$ & Shah Nawaz Khan - Ma'āthir al-Umarā \\
\hline Nizām & Nizām al-dīn Awliyā Awrangābādī - Nizām al-Qulūb \\
\hline$N A$ & Zahūr Khān Zahūr - Nūr al-Anwār \\
\hline$R A$ & Ghulām 'Alī Āzād Bilgrāmī - Rawzat al-Awliȳa \\
\hline$R H$ & 'Ināyat Allāh Khān Awrangābādī - Tadhkira-ye-Riyāz Husayn̄̄ \\
\hline Saw & Khāksār Sabzawārī - Sawānih \\
\hline Tadh & $\begin{array}{l}\text { 'Abd al-Jabbār Khān Malkāpūrī - Mabbūb-e-Dhì'l-Minan: Tadbkira- } \\
\text { ye-Awliyā-ye-Dakan }\end{array}$ \\
\hline
\end{tabular}

Tadh 2 'Abd al-Jabbār Khān Malkāpūrī - Mabbūb al-Zamān: Tadbkiraye-Shu' arā-ye-Dakan

Takmila Gul Muhammad Ahmadpūrī-Takmila-ye-Siyar al-Awliyā

TK Ghulām Imām Khān - Tārìkh-e-Khürshìd Jāhī wa Tārīkh-e-Khujista Bunyād

Tuhfa Afzal Bēg Qāqshāl Awrangābādī - Tuhfat al-Shu'arā 



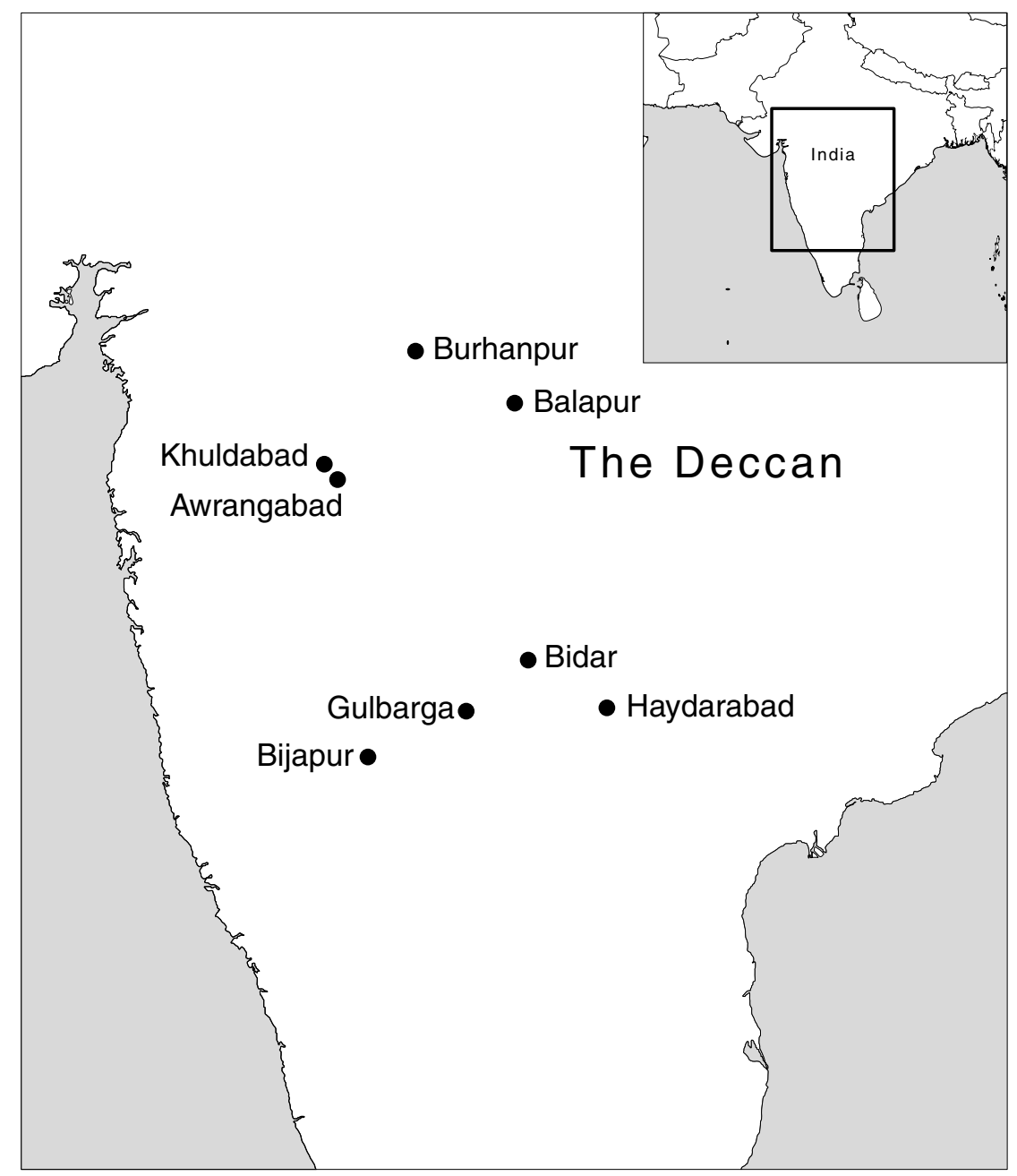

Map 1 The Deccan (inset): India

Source: Courtesy Collins Bartholomew Ltd 2005. Digital data with permission of HarperCollins Publishers. 



\title{
MUSLIM MYSTICS IN AN AGE OF EMPIRE
}

\author{
The Sufis of Awrangabad
}

\begin{abstract}
As soon as he started to build there, Awrangzeb renewed the country of the Deccan with the buildings of Awrangabad, which is one of the great cities of the world. Its suburbs are also beautiful, and they sell gold there as though the sky had asked for a shop to sell its stars. ${ }^{1}$
\end{abstract}

\section{Introduction}

The city of Awrangabad was the heir to a long tradition of urban immigration and cosmopolitanism in the southern region of India known as the Deccan. In 1019/1610 the city was founded in the name of the Nizām Shāh rulers of nearby Ahmadnagar by a former Ethiopian slave, Malik 'Anbar. ${ }^{2}$ In this first incarnation, under the name Khirki, Awrangabad stood as the last major city to be founded by the independent sultanates of the Deccan prior to the region's conquest by the Mughal empire of Hindustan (in precolonial usage, North India as opposed to the Deccan). But in spite of this early history, Awrangabad would owe its fame, name and subsequent architectural as well as broader cultural and religious character to the period beginning with the Mughal defeat of the Nizām Shāhs in 1047/1637. ${ }^{3}$ After the initial Deccan conquests of Shah Jahan (commanded by the youthful Awrangzeb), following his own accession to the Mughal throne Awrangzeb moved his court to the Deccan and refounded the city in 1092/1681. ${ }^{4}$ His choice of the city as the centre for his wider conquests of the independent Muslim kingdoms of the Deccan was perhaps fitting, for the migrant Persian geographer Sādiq Isfahānī (fl.1045/1635) had earlier interpreted its name of Khirki as signifying the 'gateway' opening onto the Deccan. ${ }^{5}$ What was in the eyes of its conquerors the good fortune of the city also soon earned it the sobriquet of Khujista Bunyād, 'the auspiciously founded'. Following Mughal custom, however, Awrangzeb also honoured his new capital with his own name and it was with the royal eponym of Awrangabad that the city eventually settled.

As the royal centre of what was in this period perhaps the richest empire in the world, Awrangabad was quickly endowed with a host of public and private buildings. The most famous of these was to be the last great royal garden-tomb to be the built by the Mughals, the 'second Taj Mahal' built for the wife of Awrangzeb on the northern limits of the city that remains the greatest Mughal monument in the 


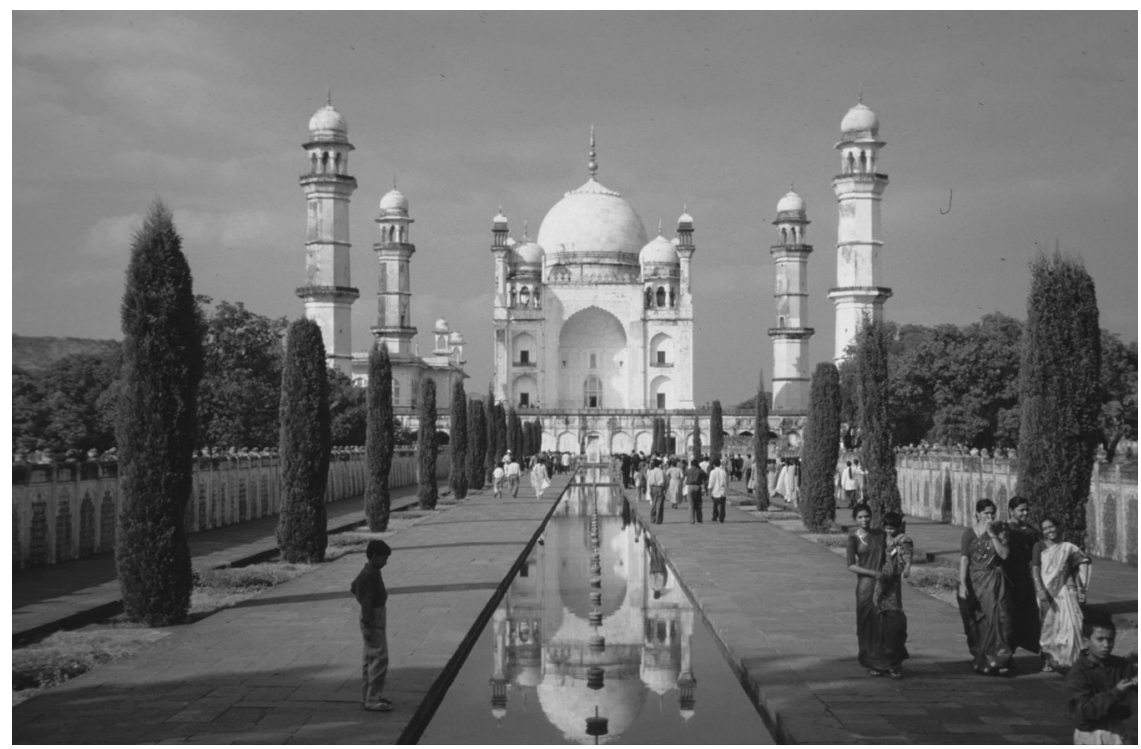

Figure 1.1 The mausoleum of Awrangzeb’s wife (Bibi ka Maqbara) in Awrangabad.

Deccan (Figure 1.1). However, imperial and sub-imperial patronage led to the construction of numerous other buildings across the city, from a royal palace designed after the models of the 'red forts' of Delhi and Agra to aristocratic mansions, markets, mosques and eventually shrines for the new city's emergent Sufi saints. In 1667, during the early years of Awrangzeb's reign, the French traveller Jean de Thevenot stayed in Awrangabad and penned a memorable description of its early cityscape. After pouring praise upon the recently completed mausoleum of the emperor's wife, Thevenot went on to record his other impressions of the city.

There are several other pretty fair Mosques in this town, and it is not destitute of publick places, Caravanseras and Bagnios. The buildings are, for the most part, built of Free-stone, and pretty high; before the Doors there are a great many Trees growing in the Streets and the Gardens are pleasant and well cultivated, affording refreshment of Fruit, Grapes, and Grass-plats....This is a Trading Town and well Peopled, with excellent Ground about it. ${ }^{6}$

Numerous other foreigners visited the city over the following decades, whether European diplomats and merchants or the larger body of Christian Armenian traders with whom they usually lodged in Awrangabad. As the city gradually acquired further architectural additions to its urban topography during its period as the founding capital of the successor state of Haydarabad from c.1136/1724 to 1178/1763 
others also penned descriptions of the city. The eighteenth-century belle-lettrist and man-about-town Shīr 'Alī Afsūs (d. 1223/1808) was particularly complementary. Making a pun on the meaning of the word awrang ('throne', but also 'sky', 'coloured paint'), he wrote that

the prince [Awrangzeb] peopled a city....and called the name of it Awrangabad, for his eyes, from seeing the colour and beauty of that city, enjoyed pleasure, and from its extent, his afflicted heart expanded at once; its air also is charming like the spring breezes, and its buildings are pleasing to every man of taste; its water has the effect of wine of grapes; every season there is good, and fresh like the spring ... [I]n the gardens and woods there are also fruits of every kind, very plentiful, well-tasted and nice coloured; besides this there is always plenty of corn and lots of grain; various kinds of cloths of good texture, and good jewels, rare and costly, are obtainable at all seasons; besides this, rarities of every country, and curiosities of every land, are procurable, whenever you desire them. Its inhabitants also dress and feed well, and are generally wealthy and rich, and the beautiful ones are altogether unequalled in loveliness and coquetry. ${ }^{7}$

Before the later drain of the Maratha wars, the first decades of the Mughal presence saw Awrangabad lay the blueprint for the final phase of Mughal architectural history. Among the first projects of Awrangabad's new rulers was the building of a great palace, which the English ambassador Sir William Norris noted as towering above the urban skyline, and the girding of the city with 6 miles of walls and 12 major gates. The late Mughal architectural practices of uncovered tombs, the emphasis on architectural verticality and the embracing of the pliant possibilities of stucco took shape during the period of Awrangabad's preeminence before their eventual export to the north with the permanent return of the court to Delhi after the death of Shah 'Alam in 1124/1712. Trade was also diverted to the city from the earlier Deccan cities by the presence of such wealth, and Awrangabad was to maintain its role as a regional entrepôt long after the Mughal princes departed, and the population of the city continued to grow through the first half of the eighteenth century. The manufacture of the embroidered silks originally purchased by the elites of empire remains the city's oldest industry to this day. Against this background, the flow of Central Asian and Hindustani dervishes had no less a colonial dimension than the conquests of the emperor himself. It remains important to stress, however, that this was not so much a Muslim colonization of a Hindu region as a Mughal colonization of a region governed for centuries by other Muslim powers. Competition and colonization, then, were directed towards fellow Muslim political and cultural rivals rather than Hindus, who as bureaucrats and traders were often significant partners in the Mughal imperial project.

Although Awrangzeb seems not to have resided in Awrangabad after 1095/1684, choosing instead to live permanently in his roving military encampment, the city retained its character as the primary military outpost of the empire's new territories. 
And to the extent that the city developed as an aristocratic centre it was of an expressly imperial kind. Its population during this heyday has been estimated at some 200,000, spread through no fewer than 54 suburbs. ${ }^{8}$ Laid out principally under military and ethnic criteria, these suburbs were named after the generals or communities residing there, as for example in the quarters known as Jaysinghpura and Mughalpura. ${ }^{9}$ Describing the city as 'inhabited by many Rich merchants, ye Govermt Greate \& profitable', the English ambassador Norris stayed in one such suburb, which he recalled as 'Coranporee', when he passed by the city in $1701 .^{10}$ Several large caravanserai were built on the edge of the city to accommodate merchants, one of which contained almost 200 domed chambers. But while commerce had certainly contributed to the city's wealth during the first decades of the Mughal presence, the city maintained a strong military dimension to its character throughout Awrangzeb's rule as the erstwhile military as well as cultural centre of a powerful and still expanding empire.

If political dissolution, literary brilliance and mystical revival have each been seen as characterizing the period of the precolonial North Indian 'twilight', then all these shared part of their roots in Mughal Awrangabad. ${ }^{11}$ For during its first century, Awrangabad stood at the crossroads of many of the developments that would shape the course of Indian history during the century to come. The first century of the city was played out against the background of final Mughal expansion and the subsequent fracture of the imperial realm into a number of successor states keen to draw upon the legacy of Mughal prestige. Yet it is too easy to see this period as a time of the unravelling of empire, of the fraying and rending of a grand and princely rug. The period of Awrangabad's heyday was as much one of creativity as destruction, quickened with the bustle of peoples from across Islam and India. Mughal Awrangabad witnessed the meeting of the cultures of the Indian north and south; it was the jewelled city in a blackened and war-torn landscape later witnessed by the French traveller Claude Martin; it was also a city of great opportunities. This was not only the case for Mughal generals like the future founder of Haydarabad State, Nizām al-Mulk (d. 1161/1748), for poets like the great Walī Awrangābādī (d. 1119/1707) also saw these bright possibilities. ${ }^{12}$ During its first century Awrangabad consequently acted as an important centre of literary production in Persian and Urdu, a role that has often been obscured by the later re-establishment of the literary primacy of Delhi and the rise of Lucknow and Haydarabad as its successors.

\section{Sufis in an Age of Empire}

Many Sufis also saw their fortunes as inextricably linked to those of the new city and it is against this wider literary background that Sufi writings from the city must be seen. Yet it was also amid the imperial atmosphere of Awrangabad that the lives of its Sufis were enacted. For Sufis and soldiers were frequent companions in Mughal Awrangabad, often bound together by shared faith, heritage and ethnicity no less than interwoven fortunes. Highlighted in the following account of Sufi lives in the Mughal city are associations with the royal court, the corporate nature of discipleship 
and the varieties of style and practice at work under the broad nomenclature of Sufism (tasawwuf). Each of these forces was of importance to the development of the shrines and the posthumous images of the city's Sufi saints. Their careers reveal the social identities of the living Sufis as well as the social contexts that formed the cradle of saintly cults. The careers of the living shaykhs described in this chapter may in this sense be seen as the pre-history of their shrine cults, whose own development and fortunes are described in subsequent chapters.

Sufism was a thriving concern in the Mughal heyday of Awrangabad. Sufis from the Chishtiyya and Naqshbandiyya, the major Sufi traditions of the day in India, as well as dervishes unattached to any specific Sufi lineage (silsila), all gathered in considerable number in the city. Interacting with the merchants, notables and soldiers of the city, many of the city's Sufis also possessed these other social identities in addition to that of a formal Sufi initiate (murid $)$. The number of 'full-time' Sufis individuals whose social identity was constructed in exclusive terms of the dervish life - was of course smaller. Among these professionals of the soul, four Sufis emerged as the greatest capturers of large and moreover influential constituencies of followers in Awrangabad, founding the patronal associations that would help to ensure the continuation of their cults of fellowship after their deaths. These Sufis - the unaffiliated (or possibly Qādirī) Shāh Nūr, the Naqshbandī Shāh Palangpōsh and Shāh Musāfir and the Chishtī Nizām al-dīn - were the Sufis who were later transformed into the city's foremost saints.

By the time Awrangzeb moved his court permanently to the Deccan, Sufis from a wide variety of traditions could look back upon a long history of their 'orders' (turuq) across not only India in general but the Deccan in particular. ${ }^{13}$ Although Qādirī Sufis enjoyed considerable importance in the medieval Deccan, the region also became associated early on with the Chishtī order through the transfer of the Delhi-based tradition to nearby Khuldabad in the fourteenth century. ${ }^{14}$ However, many other Sufi groups enjoyed considerable success in different parts of the region, with Bijapur as an important centre for Shattārī as well as Qādirī and Chishtī Sufis and Bidar pivotal in the history of the Ni'mat Allāhī brotherhood before its reintroduction to Persia in the eighteenth and nineteenth centuries. Such Sufis therefore gathered in centres of political importance and did so for reasons of patronage, safety and propagation. The richest contemporary source on Sufism in the Mughal city, the Malfüzät-e-Naqshbandiyya that was mainly compiled from the mid-1140s/1730s by the Sufi resident Shāh Mahmūd (d. 1175/1762), describes a good many of the kinds of comings and goings we have just sketched. ${ }^{15}$ There were, of course, the dervishes, no mean proportion coming from as far as Central Asia and Persia. Then there were the fighting men of all ranks, from the elevated station of the great Mughal soldier Ghāzī al-dīn Khān Fīrōz Jang (d. 1122/1710, Awrangzeb's greatest general in the Deccan) to the many humbler men of fortune having business with the Sufis whom Shāh Mahmūd commemorated. ${ }^{16}$ Like the Awrangabad Naqshbandīs, Ghāzī al-dīn and many others of these soldiers were immigrants from Central Asia. Contributing in large part to the city's wealth were the merchants we have seen among the city's visitors and erstwhile residents; like Awrangabad's amirs and princes, they too occasionally made 
donations to the coffers of the city's Sufis. ${ }^{17}$ The other major textual source on this period is the collection of the 'recorded conversations' (malf $\bar{u} z \bar{a} t$ ) of the Sufi Nizām al-dīn (d. 1142/1729) entitled Absan al-shama'il. Along with a series of other hagiographical and occasionally doctrinal works, these sources allow us to build up a picture of considerable detail of the Sufi circles of Mughal Awrangabad.

The Sufis of Mughal Awrangabad acted as the sources and recipients of authority in a society in which Sufi and courtly power sometimes competed but just as often complemented one another as the natural state of affairs in the world. As the Malfüzāt-e-Naqshbandiyya demonstrates, a considered acceptance of the king's shilling, far from entailing an abandonment of a lowlier clientele, actually provided the means by which that clientele could be helped. Like their posthumous shrines, the living Sufis often formed a means of brokerage and interaction between the few possessors of power and wealth and the more or less indigent masses in a society where the allotment of resources was strictly vertical. This interaction between the living Sufis of Awrangabad and members of the city's elites belies the image that such interactions occurred mainly at the deplorable 'shrine stage' of Sufism.

Such a concern for politics and the world grew partly out of the daily engagement of the masters of Awrangabad with the immediate and mundane concerns of the societies around them. An understanding of Sufism as spurning all concern for matters of this world is plainly a misunderstanding, for either in their mystical or practical admonitions Sufis have rarely proposed complete disengagement from society. The picture of the Sufis abstracted from worldly affairs is perhaps in the main the reflective luxury of a stable and comfortable world. As the early Awrangabad texts reveal, Sufis were as often involved in curing the sick, praying for rain or unveiling brigands as in the ignoring transcendence of the worldly affairs of their neighbours. For while Awrangabad was a royal city, it was no less a city of impoverished souls inhabiting the thatch dwellings of the urban masses. Between palace and chantier, Awrangabad's Sufis played the different roles appropriate to their varied and demanding clientele, ranging from attendance at the wedding of the son of an eminent general to helping poor widows and the sick. ${ }^{18}$

By the seventeenth century, multiple Sufi initiations were commonplace in India and we know that Nizām al-dīn, the most subsequently famous of the Awrangabad Sufis, was received into the Naqshbandī and Qādirī orders as well as what posterity would regard as his own particular branch of the Chishtiyya. The use of Naqshbandi meditational chants (dhikr) by the circle of Nizām al-dīn was mentioned in the latter's biography ${ }^{19}$ and also described at some length in the manuals on dhikr of both Nizām al-dīn and his master Shāh Kalīm Allāh. ${ }^{20}$ Yet despite this, there was a certain discreteness among the Sufi gatherings in Awrangabad, one based on the shared cultural, linguistic and in some sense ethnic inheritances of the different communities which populated the short-lived Mughal metropolis. This perhaps reflected the division of Awrangabad's urban geography into dozens of suburbs making up the distinct enclaves of these different communities. One of these quarters, Mughalpura ('Mughal quarter'), was the residence of many of the followers of the Central Asian Naqshbandī Sufi, Shāh Musāfir. Other Sufis seem to have been tied in some form to the city's large community of Persian immigrants and their descendants. 
The Sufis attracted to Awrangabad by the rich and varied possibilities available during its Mughal heyday represented a cross section of several of the different styles of Sufi practice common to their age. Hailing from different homelands and different Sufi traditions, their own spiritual apprenticeships (more or less learned, more or less sober vis-à-vis association with non-Muslims and the use of music) combined with their own distinct regional cultural heritages (North Indian or Central Asian) to present a diversity of imagery and practices capable of acting as boundary-markers that could define their sources of power and styles of tasawwuf as distinct brands for their followers and other contemporaries. Yet amid this considerable diversity, four Sufis shared much in common. Each of them belonged to the bifurcated Central Asian and Indian cultural sphere of the city's Mughal rulers, in whose wake each of them had likewise travelled to the Deccan. In this sense, they were all strangers to the Deccan. Each of them, then, was in some sense an imported holy man, connected not primarily to the Muslims of the Deccan but to the migrant North Indian or Central Asian Muslims who travelled in the Deccan. In this respect they suited the tenor of their adoptive city perfectly in its role as an outpost of North Indian politics and culture.

The lives of Shāh Nūr, Shāh Palangpōsh, Shāh Musāfir and Nizām al-dīn demonstrate the varied types and traditions operating in Mughal Awrangabad within the broader framework or rhetoric of tasawwuf. This is seen not only in their membership of three different Sufi 'orders', but also in their manifestation of the different reaches - literary, ethnic or stylistic - of Sufi life. In the case of Shāh Nūr, short references in a contemporary biographical dictionary of Mughal notables and the existence of two early albeit posthumous commemorative texts (tadhkirāt) allows insight into the style, if not always the detail of his life, while in the case of the three remaining Sufis we are fortunate in possessing contemporary records of their careers. It is to these texts that we now turn to gain a more detailed picture of Sufi life in the Mughal city.

\section{Shāh Nūr}

Shāh Nūr, the earliest of the Sufis studied in this book, was a resident in Awrangabad before the arrival of either the Chishtī Nizām al-dīn or the city's Naqshbandī shaykhs, Shāh Palangpōsh and Shāh Musāfir. In the biographical dictionary Ma'āthir al-umarā of Shāh Nawāz Khān, written in Awrangabad a few decades after the death of Shāh Nūr in 1104/1692, Shāh Nūr is briefly described by virtue of his relationship with the erstwhile governor (dīwān) of the Deccan, Diyānat Khān, who was himself the great-uncle of Shāh Nawāz Khān. ${ }^{21}$ Although Nūr al-anwār, a late recension of the earliest full account of Shāh Nūr's life by Bahā' al-dīn Hasan 'Urūj (d. c. 1230/1814) records the saint's place of birth as Baghdad, the Ma'äthir al-umarā records that Shāh Nūr's followers believed him to be from the Pūrāb, that is the eastern sector of Hindustan. ${ }^{22}$ In view of Shāh Nūr's later succession by a follower from the same region of the north, and the proliferation of Baghdadian themes and associations otherwise only in the later memorial tradition, a homeland for Shāh Nūr 
in eastern Hindustan, that is north-eastern India, seems likely, leaving open the possibility that he was born there to a family of Arab descent. From his North Indian homeland, Shāh Nūr probably travelled gradually to the Deccan. Later hagiographies credit him with extensive travels across the Muslim world, though the augmentative nature of such itineraries leaves them open to considerable doubt. More certain is that Shāh Nūr had arrived in Awrangabad by the 1070s/1660s, early in its transition to the Mughal metropolis it was by then becoming. ${ }^{23}$ On his arrival, he settled in the Moti Karanjar quarter, establishing a retreat (bujra) and subsequently a proper Sufi lodge or khanaqah there. ${ }^{24}$ This quarter belonged to the earliest stage of the city's development and was originally a Hindu village prior to Malik 'Anbar's establishment of Awrangabad's predeccessor, Khirki. Far away from either the royal quarters of Awrangzeb's new city where other khanaqahs would be founded in the following decades or the grand suburbs built after the arrival of the attendants of empire, the location of Shāh Nūr's first gatherings indicates the lowliness of his status in his early days in the city. As his following grew, these circumstances changed and some years later (around 1091/1680?) a large khanaqah was built for him by a wealthy devotee, Diyānat Khān, in the prestigious surroundings of the imperial suburb of Qutbpūrā. ${ }^{25}$ Upon his death with neither wife nor offspring in 1104/1692, in accordance with Sufi custom Shāh Nūr was buried within this extensive khanaqah. ${ }^{26}$

Shāh Nūr managed to attract a considerable body of devotees during his lifetime. The fact that upon the arrival in Awrangabad around 1093/1682 of Shāh Musāfir, the founder of the Naqshbandī tradition in the city examined in the following sections, he stayed in the retreat (takiyya) of one of Shāh Nūr's followers, Shāh 'Ināyat Darwīsh, is indicative that Shāh Nūr's following in the city was well organized by this time. ${ }^{27}$ For during his years in Awrangabad, Shāh Nūr attracted a following that included several influential figures from the city's government and administration. Foremost among these was the aforementioned Diyānat Khān, a courtier belonging to an İānī family (i.e. a family of Persian migrants or their descendants) who were wellestablished in Awrangabad with strong links to the Mughal imperial bureaucracy. During the reign of Awrangzeb, Diyānat Khān held the post of dīwān of the entire Deccan and remained resident in Awrangabad partly by virtue of this position. ${ }^{28}$ Diyānat Khān also lived in the Qutbpura quarter. ${ }^{29}$ It seems due to Diyānat Khān's residence there that the site of Shāh Nūr's gatherings was moved from the poorer Mochiwara quarter to the large khanaqah (and subsequently mausoleum) which Diyānat Khān's son (also later known as Diyānat Khān) established for Shāh Nūr near to his family residence. ${ }^{30}$ This second Diyānat Khān was also a disciple of Shāh Nūr and, as the financial administrator (mutasadd $)$ ) of the principal Mughal port of Surat, also later became the companion and patron of Shāh Nūr's follower, Shāh 'Ināyat. ${ }^{31}$ This Diyānat Khān was buried near to Shāh Nūr after his death in c. 1141/1729.

Several other official figures of the Mughal administration in the city were among Shāh Nūr's followers, including the chief judge ( $q \bar{a} z \bar{i}$ al-quzāt) and market regulator (mubtasib) of the city, Muhammad Ikrām and Qāzī Muhammad Mas'ūd. ${ }^{32}$ One of the wives of Awrangzeb may also have been a disciple. ${ }^{33}$ It was precisely Shāh Nūr's associations with members of this cultured and elite class that were reflected in his 
nickname of Hammāmī ('of the bathhouse'). Like the family of Diyānat Khān, these followers may have been drawn from Awrangabad's İrānī community, itself made up partly of recent immigrants to the city in the service of the Mughals and partly of families in residence there since the period of Nizām Shāh rule. Many of the latter were Shi 'is like several of their former Nizām Shāh rulers, and the reference to Shāh Nūr as a Husaynī sayyid in one of the earliest accounts of his life may also reflect a Shi 'i dimension to this clientele. ${ }^{34}$ Shāh Nūr's principal patron Diyānat Khān was certainly the most prominent İrān̄i in Awrangabad, while Shi' $\mathrm{i}$ connections later lingered about the shrine and cult of Shāh Nūr for centuries. ${ }^{35}$

As we have seen, the earliest version of Shāh Nūr's name refers to him as Shāh Nūr Hammāmī. ${ }^{36}$ In the Ma'athir al-umarā, this name was ascribed to his practice of giving each of his visitors enough money to visit a bathhouse. However, a few decades later the name was explained by the hagiographer Sabzawārī as being due to the saint's ownership of a bathhouse (hammām) in Awrangabad where people went to meet him. ${ }^{37}$ Despite these apparent oddities, the earliness of the title and the attention given to it suggests that Shāh Nūr did indeed have some kind of link with customs or places of bathing and that these links were of sufficient cultural significance to be worthy not only of recording but of naming the master in their memory. The imagery of the hammām seems to have functioned here as an elite cultural symbol, for bammāms were widely regarded as an adjunct of the wealth and cultivation of the Mughal elites. The construction of hammams in India had greatly increased after the Mughal conquests: Babur built many, while at Fatehpur Sikri the house of every notable had its own hammām. ${ }^{38}$ When the Khān-e-Khānān 'Abd al-Rahīm built for himself the quarter of Jahangirpura in Burhanpur in the northern Deccan that would become a by-word for elegant living, the foundation of hammams played a central role in his plans. ${ }^{39}$ Not only a symbol of Mughal technology and high culture, through their courtly and aristocratic use as chambers of private council, as an eastern equivalent of the Elizabethan privy council they were also a symbol of political power and the privilege of access to it. ${ }^{40}$ In the Mughal show-piece of Awrangzeb's new city, the nickname (laqab) Hammāmī was perhaps therefore a title resonant with associations of the political power and the refined culture of the Mughals as manifested in Awrangabad.

Some decades later, Shāh Nūr's kin-name (nisba) was given as Hamadān̄̄ in reference to his family lineage. ${ }^{41}$ It is unclear whether the nickname gradually metamorphosized into a similar sounding family name denoting prestigious foreign origins. According to the earliest source referring to the saint's kin-name of Hamadān̄̄, Shāh Nūr was the son of Sayyid 'Abd Allāh ibn Abū 'Alā' Hamadān̄̄ and a Husayni sayyid, that is a descendant of the Prophet Muhammad via his grandson Husayn. However, the Ma'äthir al-umarā recorded no details of Shāh Nūr's parentage other than that he was thought to be the son of a rich man from the north-east. ${ }^{42}$ Despite the claims of the biographer Bahā' al-dīn Hasan 'Urūj of Shāh Nūr's Sufi initiation at the hands of Shāh Qutb al-dīn Qutb Hamawī in Baghdad, it cannot then be said with any certainty what Shāh Nūr's spiritual lineage was. ${ }^{43}$ In modern times Shāh Nūr is widely regarded as having been a Qādirī Sufi. This claim is bolstered by 
a statement to the same effect in the Makbzan al-a'rās, a calendar of Muslim saints' days based on an earlier version written in Awrangabad around 1155/1742-3. ${ }^{44}$ But any claims of an extra-Indian initiation should be viewed with caution and despite the claims to a Qādirī affiliation, the Ma'äthir al-umarā claimed that Shāh Nūr himself never spoke of belonging to any order (tariqqat), nor even of the business of mastery and discipleship in general. ${ }^{45}$ In view of this, it seems likely that Shāh Nūr belonged rather to that more autonomous tradition of individualist dervishes who lived and taught outside the bounds of formal membership of the Sufi orders that had also included such luminaries as the great Andalusian Sufi, Ibn 'Arabī (d. 638/1240). The Ma'äthir al-umarā adds that Shāh Nūr's order only came into being after his death. ${ }^{46}$

Shāh Nūr also seems to have had contact with the Hindu ascetics who, with their long-established association with Hindu holy sites in the region of Awrangabad, formed part of the religious life of the city with which Sufis sometimes interacted. Indeed, shortly after Shāh Nūr's death, the circle surrounding the Chishtī Sufi Nizām al-dīn (d. 1142/1729) in Awrangabad also included a number of Hindus. ${ }^{47}$ Although it is difficult to be sure with how many of these Hindu ascetics Shāh Nūr was associated, surviving literary and architectural evidence bears witness to his close connections to at least one such figure, the noted Sadhu Mānpūrī Parshād. ${ }^{48}$ Mānpūrī later became the focus of a posthumous cult in his own right that centred on his lodge (math) a few miles outside Awrangabad at Dawlatabad. ${ }^{49}$ An anthology survives of Mānpūrī's devotional poems (bhajans), blending the vocabulary of Sufi and Sadhu and pointing to the close links forged at this time between Muslim and Hindu mystics in the Deccan. One of the poems said to address Shāh Nūr is preserved in an eighteenth century poetic anthology (tadbkira) that was compiled in Awrangabad by 'Ināyat Allāh Khān Awrangābādī. 50

Leaving no written works of his own, Shāh Nūr was some way detached from the Sufi writers of sophisticated verse and theory. He seems to have belonged to a tradition of Sufi men of power, possessors of the mysterious abilities valued greatly in premodern societies as important members of both community and state. Together with his aristocratic associates and cultured associations, this was sufficient to enable him to attract a clientele from among not only faqīrs like himself (whether Muslim or Hindu), but also from among the classes of officialdom associated with Awrangabad's position at the centre of the empire. The partisanship of such Sufis was recognized to be as much an aid in worldly success and security as in achieving more spiritual ambitions. Yet while both spiritual longing and Shāh Nūr's own religious and political badges of honour were factors in this strange union of officials and faqīrs, the many surviving descriptions of miraculous encounters between Shāh Nūr and these clients remind us that the main reason behind Shāh Nūr's success may have been more straightforward. Of paramount and day-to-day importance in the Mughal city, this was the matter of the belief in the possession of supernatural power. The Venetian traveller Niccolo Manucci (d. 1717) demonstrated the scale upon which such power was seen to operate in his description of the desperate visit of Awrangzeb's brother Dara Shikoh, close to defeat in his war with Awrangzeb for control of the empire, to plead for supernatural assistance at the shrine in Multan 
of the medieval Sufi, Bahā' al-dīn Zakariyā. ${ }^{51}$ Such a visit would have surprised few of his contemporaries. The visitation by courtiers to holy men even formed a popular genre of Mughal miniature painting, reflecting not only the frequency of such encounters but also the ways in which they were churned in the cultural imagination and transformed into a topos of the natural order of things. Shāh Nūr's perceived ability by his contemporaries to stand at the cross section of such powers - between God and empire - appears to have been a defining factor in his Sufi career. For the posthumous development of his cult at least, it was a factor of greater importance than such Sufi activities as the provision of spiritual guidance and the writing of pious tracts.

\section{Shāh Palangpōsh and Shāh Musāfir}

Described in great detail by their first spiritual successor (sajjāda nashīn), the lives of the Naqshbandī Sufis Shāh Palangpōsh (d. 1110/1699) and his disciple Shāh Musāfir (d. 1126/1715) confirm the importance of access to supernatural power, revealing a pragmatic and at times bewildering dimension to the practice of Sufism in Mughal Awrangabad. $^{52}$ Both shaykhs migrated to the Deccan on the trail of the region's northern conquerors as immigrants from the important Naqshbandi shrine-centre of Ghijdawan in Central Asia. ${ }^{53}$ Prior to their migration they had spent one or two decades in the towns of present-day Afghanistan and their hagiography, the Malfüzāt-e-Naqshbandiyya, describes several episodes in their earlier lives set in such towns as Karshi, Kabul and Hasan Abdal. ${ }^{54}$ The shaykhs' itineraries followed a welltrodden trail along the trade route between the cities of the Mughals' ancestors in Central Asia and those of their newer empire in Hindustan and the Deccan. ${ }^{55}$ In view of the long and close connections of the Mughals with the Naqshbandī order, the arrival in Awrangabad of a pair of its representatives was only to be expected. The father of the founder of the Mughal dynasty, Babur, had been a devotee of the great Central Asian Naqshbandī Khwāja Ahrār, whose Risāla-e-wālidiyya Babur translated into Chaghatai, and this affinity with the Naqshbandī order continued, waxing and waning, with Babur's descendants. The connections of Shāh Palangpōsh and Shāh Musāfir with Ghijdawan perhaps also struck a chord with those associated with the ruling house, for it was at Ghijdawan in 918/1512 that Babur had suffered the decisive defeat at the hands of the Üzbeks that had first propelled him towards India. The spread of Naqshbandī Sufism in the Deccan, as indeed in India more generally, was closely associated with Mughal rule. Burhanpur, the centre for the onset of the Deccan conquests under Shah Jahan, had become an important Naqshbandī centre in the decades before Shāh Palangpōsh and Shāh Musāfir arrived in the Deccan. Prominent among the Sufis of Burhanpur was Muhammad Kishmī, who had migrated into the Mughal realms from his native Badakhshan. In India he became associated with the self-styled Naqshbandī 'renewer' (mujaddid) Ahmad Sirhindī (d. 1034/1624) and went on to establish an important circle of followers of Sirhind $\overline{1}$ in Burhanpur. In 1065/1654 another Naqshbandī circle was established some miles away from Burhanpur at Balapur by Shāh 'Ināyat Allāh (d. 1117/1705). ${ }^{56}$ As the 
Mughals gradually moved southwards, Naqshbandī holy men and members of prominent families descended from the Naqshbandī saints of the Bukhara region helped introduce the religious foundations of the Mughal cultural world of Hindustan and Central Asia into the Indian south. As Awrangzeb moved southwards from Awrangabad, in 1065/1654-5 Khwāja Barkhwurdār, one such descendant $(k h w \overline{a j} a z \bar{a} d a)$ of an earlier Naqshbandī saint, was even appointed as the commander (qila'dār) of the fortress of Awsa.

Shāh Palangpōsh was the elder of the pair, and acted as Shāh Musāfir's principal spiritual director (murshid) for most of his career, although it seems that Shāh Musāfir earlier underwent a Kubrāwī initiation that was played down after his move to India. ${ }^{57}$ This seems to have been partly a reflection of the rising star of the Naqshbandī order both in Central Asia and India and in its concomitant eclipse of the Kubrāwiyya. Shāh Musāfir had spent some time as a tutor in a prosperous household in Ghūr. ${ }^{58}$ He was perhaps in his thirties by the time he chose, like so many of his Central Asian contemporaries, to follow the route down through the mountains towards the opportunities of India and into the environs of its most powerful ruler in the Deccan. The move of Shāh Musāfir and Shāh Palangpōsh down through India probably occurred separately, though both shaykhs had probably arrived in India by 1085/1674. ${ }^{59}$ Shāh Palangpōsh had developed a reputation as a miraculous protector of armies in his Central Asian homeland, and so began an association with the Mughal army on his arrival in the Deccan that continued throughout his career. Shāh Palangpōsh then attached himself to the forces of Ghāzī al-dīn Khān Fīrōz Jang, the father of the subsequent founder of Haydarabad State Nizām al-Mulk Āsaf Jāh and commander of the principal arm of the Mughal forces in the Deccan. While he regularly passed through Awrangabad, and was eventually buried there, most of his career seems to have been spent in the roving encampments of Fīrōz Jang's army. Shāh Musāfir, by contrast, chose to settle premanently in the Mughal outpost of Awrangabad. As we have seen, he stayed first in the lodge of Shāh Nūr's disciple, Shāh 'Ināyat. ${ }^{60}$ Some time later, however, Shāh Musāfir established a thatch takiyya of his own on the outskirts of the opposite side of the city from the khanaqah of Shāh Nūr. ${ }^{61}$ Shāh Musāfir remained in Awrangabad until his death in 1126/1715. ${ }^{62}$

The accounts of Shāh Palangpōsh's behaviour during his years of military accompaniment with the army of Fīrōz Jang reveal a striking portrait of a face of Sufism that is rarely seen. ${ }^{63}$ Yet warrior dervishes, such as the famous Sayyid 'Alī Sultān, were also a feature of the history of Anatolia and other regions of Islam, including East Turkestan and the Maghreb. Their functions reflected the warrior saints of Byzantium, as well as the Sadhu brigades attached to the armies of Hindu kingdoms in India. ${ }^{64}$ During his years in the Deccan, Shāh Palangpōsh fashioned a clear role for himself as the protector of the Central Asian soldiery among the Mughal forces in their ongoing skirmishes with the Marathas. ${ }^{65}$ Although he had earlier accompanied the Mughal armies in their battles around Jalalabad, ${ }^{66}$ his especial duty was unambiguously directed towards the protection and miraculous assistance of Fīrōz Jang. ${ }^{67}$ Far from appearing desirous solely of association with such grand and titled men of war, Shāh Palangpōsh at times displayed a notable esprit de corps with the lowly 
foot-soldiers, not to mention dealing with the wine and cannabis drinkers who form the unlikely heroes of several of his military exploits. ${ }^{68}$ Nonetheless, in an incident recounted by his biographer Shāh Mahmūd in the Malfūzāt-e-Naqshbandiyya, Shāh Palangpōsh appears on horseback surrounded by a large entourage of dervish footmen and so also seems to have possessed an air of exalted military rank. In an overlapping of symbolism, the Sufi appears here as the commander of supernatural forces possessed of his own legion of holy warriors, both visible and hidden to the ordinary mortal eye. ${ }^{69}$ The imagery evoked in the meaning of Shāh Palangpōsh's name as 'the wearer of leopard-skin' belonged to the traditions of the warrior elites of the Persianate world and to its dervishes, for wandering religious mendicants and mounted warriors both partook in this sartorial symbolism. ${ }^{70}$

Shāh Palangpōsh's connections with the Mughal war effort in the Deccan may be compared to similar feats of supernatural aid expected from loyal Sufis elsewhere in the Deccan. During this period Awrangzeb made several pilgrimages to the Sufi shrine of Gēsū Darāz (d. 825/1422) at Gulbarga to the south of Awrangabad, 'removing the veil of poverty from the heads of the residents' of the shrine. ${ }^{71}$ The nature of these royal connections with the Sufis is perhaps best brought out in an episode recounted in the Ma'äthir-e-'Álamgīrì of the chronicler Sāqī Must'ad Khān, which relates to the capture in 1099/1689 of Sambhājī, the son of the Maratha leader Shīvājī, who had long resisted Mughal expansion in the Deccan. According to Must'ad Khān, Sambhājī's unexpected capture had been predicted to Awrangzeb some ten days before the event took place by Mīr Sayyid Muhammad, the descendant and former spiritual sucessor (sajjāda nashīn) of Gēsū Darāz at Gulbarga. When the prediction came true, Awrangzeb rewarded the sayyid personally and granted 10,000 rupees to the shrine. ${ }^{72}$ Mīr Sayyid's son had already been appointed as sajjāda nashīn of the shrine by Awrangzeb, who was later careful to maintain the goodwill of this representative of the most important Sufi shrine in the Deccan by awarding him at court with a jewelled dagger and a horse with gold trappings. ${ }^{73}$ Bedecked in such splendour, we see in Mìr Sayyid's appearance at court a mirroring of the description of Shāh Palangpōsh in the Malfīzāt-e-Naqshbandiyya with his attendants beside him as he rode his horse. Indeed, given the expense of importing them, horses were in themselves signifiers of rank. Such correspondences between the two figures are perhaps fitting, since the Malfüzāt-e-Naqshbandiyya also informs us that Shāh Palangpōsh was resident in Gulbarga for an undisclosed period of time prior to his eventual death there in 1110/1699. During his time in Gulbarga he regularly visited the shrine of Gēsū Darāz, and the Malfūzāt-e-Naqshbandiyya describes an encounter there one night between Shāh Palangpōsh and a luminous dervish from the 'hidden world' (ghayb) with whom he shared a meal of stale bread and sat in contemplation (murāqaba) throughout the night. ${ }^{74}$

No writer of spiritual guidebooks, Shāh Palangpōsh instead resembled the traditional supernatural guardian long familiar to the armies of Central Asia, flying before the troops he safeguarded and omnipresent among them amid the flurry of the attack. ${ }^{75}$ In one remarkable scene, during which thieves attempted to steal into Shāh Palangpōsh's tent on the battlefield, he was even claimed to have transformed 
himself into the terrifying image of a pop-eyed tiger. ${ }^{76}$ In Shāh Palangpōsh's sobriquet, with its accompanying aetiological tale of his ritualized hunting of a leopard in a forest before donning its skin, there are strong elements of the heritage of the Central Asian shamans. ${ }^{77}$ These serve as reminders of the deliberately bewildering and uncanny appearance of the wandering dervish, the master of undoubted powers but a figure of sometimes uncertain benevolence. Usually detached from the literate traditions of Sufism, such antinomian dervishes or qalandars formed an important part of Sufism in the Deccan as elsewhere. Several qalandars are mentioned in association with Shāh Palangpōsh and the other Awrangabad Naqshbandīs. ${ }^{78}$ Powerful, unsettling and surrounded by a devoted dervish retinue and a regular military troup, Shāh Palangpōsh evokes a darker dimension to dervishry in the Mughal Deccan, concerned as it was with rough and occasionally gruesome transactions. For though Shāh Palangpōsh was seen to be the possessor of undoubted spiritual powers, their employment was regularly sought for more mundane issues and only occasionally for acts directed towards the mystical transcendence of daily life. Association with a gifted Sufi was not only a question of spiritual enlightenment, but sometimes also a matter of triumph and dominion on earth.

Shāh Palangpōsh's disciple, Shāh Musāfir, affords some contrast to his master. While still showing the same concerns for his clients' quotidian complaints, Shāh Musāfir's career led him to settle more urban and domestic matters than his martially inclined master. The recollections of the followers of Shāh Musāfir of their master recorded in the Malfüzāt-e-Naqshbandiyya paint a portrait of a gentler figure, the indubitable possessor of supernatural powers yet at the same time a warm and humble character. Many closely observed anecdotes describe Shāh Musāfir paying special attention to widows and orphans, many of whom lived in his takiyya, where children (probably drawn from the Central Asian community in the city) were also given an education. The offerings of money that Shāh Musāfir received from his many Central Asian supplicants in Awrangabad were used to look after his many dependents, showing the Sufi in a social role that is not always recognized. Although sought out by men and women of diverse social status, Shāh Musāfir's clients were almost all of Central Asian $(t \bar{u} r \bar{a} n \bar{\imath})$ origin. Such ethnic restrictions on Sufi clienteles were a matter of no surprise to Shāh Musāfir's contemporaries and a similarly exclusive Central Asian circle gathered a few decades later around the Naqshbandī masters of Rai Bareli in North India. Indeed, when Shāh Musāfir had stayed at the takiyya of Shāh Nūr's follower 'Ināyat Allāh on his arrival in Awrangabad and fallen ill there, 'Ināyat Allāh had panicked, declaring that since the elite classes (ashrāf) attended Central Asian Sufis like Shāh Musāfir, the Mughal governor of the city would surely make trouble for him if the Central Asian Sufi should die while he was his guest. ${ }^{79}$ Yet a more sinister aspect also lingered about his character that was connected to his mysterious powers, as when a young Baluch suddenly died after inadvertently insulting him while under the influence of cannabis. ${ }^{80}$ Such powers were not only associated with eighteenth-century Sufis like Shāh Musāfir, for early hagiographies of the twelfth century Khurasani Sufi Ahmad-e-Jām (d. 536/1141) similarly record the striking blind, mute and dead of those who insulted him. Once again, the ambiguous powers 
of such Sufis reflect those of the sabios of the Mediterranean. Nevertheless the use of cannabis preparations (bhang), opium and tobacco all formed a part of the local culture into which Shāh Musāfir and his Central Asian compatriots arrived in the Deccan, and all were at some point consumed at the takiyya to Shāh Musāfir's general but not exclusive disapproval. ${ }^{81} \mathrm{He}$ did, however, draw the line at some of his followers' attempts to bring dancing-boys into the takiyya. ${ }^{82}$

Begged for his help as the reliever of illness and misery, of dispute and crime, Shāh Musāfir was by no means concerned only with matters pertaining to an abstracted spiritual progress and was called upon to cure a variety of illnesses, including epilepsy and a variety of mental disorders. ${ }^{83}$ In another instance, his intercession was seen to cause rainfall during a drought, ${ }^{84}$ while it was suggested that he helped protect the city during a Maratha raid. ${ }^{85}$ In a reflection of Naqshbandī sensibilities Shāh Musāfir's technique was usually disarmingly simple in these situations: he came to the scene, often in the company of a small group of followers, and recited the opening verse of the Quran, the Fātiha. In such narratives, we glimpse the Sufi as refuge and protector of the poor and weak, a figure of hagiographic and historical importance. Yet like his master, Shāh Musāfir was also associated with the Central Asian military elites of the city whom he also sought to protect. Associated with Fīrōz Jang like Shāh Palangpōsh, Shāh Musāfir was present at the wedding ceremony of the general's son, Qillīch Khān (later known as Nizām al-Mulk Āsaf Jāh), where he symbolically assured the long life of the youth by preventing the premature blowing out of his candle by ill-omened winds. ${ }^{86}$ On another occasion, Shāh Musāfir presented a turban and a poetic blessing to Nizām al-Mulk, in which the Sufi's biographer later saw the miraculous granting of Nizām al-Mulk's future rule over the Deccan. ${ }^{87} \mathrm{~A}$ barakatladen sleeve granted by Shāh Musāfir to one of his military followers was also carried into battle on the side of Nizām al-Mulk. ${ }^{88}$ Many of the regular disciples (murīds) of Shāh Musāfir - and even more so of Shāh Palangpōsh - either were or had been soldiers fighting for the establishment of Mughal sovereignty of the Deccan. ${ }^{89}$

While no accompanier of armies himself, Shāh Musāfir did give blessings to soldiers at his takiyya in Awrangabad, some of whom also brought their arrows there to be blessed. Such practices were also described in Indian treatises of a century earlier, and echoing wider belief in the saints' powers on the battlefield, Rūmī had earlier written that 'the saints can turn back the arrows to the bow'. ${ }^{90}$ Although there is no specific mention of this practice in the Malfüzāt-e-Naqshbandiyya, the head of Awrangzeb's archers was one of Shāh Musāfir's disciples, ${ }^{91}$ and a large collection of eighteenth-century bows and arrows survives in the reliquary of Shāh Musāfir's shrine. Shāh Palangpōsh was personally associated with the use of bows and arrows, having used a bow in his youth to slay the leopard (palang) which gave him his coat and name, and having later continued to use his bow in battle alongside Fīrōz Jang. ${ }^{92}$ It seems possible, therefore, that the arrows preserved at the shrine belonged to Shāh Palangpōsh.

Tied in similar ways to the political life of Awrangabad, Shāh Musāfir was also present at one of the early death anniversaries ("urs) of Awrangzeb beside his grave in neighbouring Khuldabad. ${ }^{93}$ Fittingly, Nizām al-Mulk later paid a visit to Shāh 
Musāfir as he lay on his deathbed at the shrine. ${ }^{94}$ Indeed, Shāh Musāfir's followers even regarded him as being miraculously responsible for the successions to the Mughal throne that followed Awrangzeb's death. ${ }^{95}$ One of the dervishes also saw a vision of Shāh Musāfir seated upon a throne with Awrangzeb's sons and successors, Muhammad Kambakhsh and Bahadur Shah, positioned to either side, a political vision similar to that witnessed around the same time by the Sufi 'Abd al-Razāq in Lucknow. Sufi predictions of the careers of princes were far from uncommon, and the textual tradition of the medieval North Indian Sufi Khwāja Gurg similarly recorded his prophecy of the rise of 'Alā' al-dīn Khiljīi; other examples are legion. ${ }^{96}$ However, at a more mundane level the political sympathies of Shāh Musāfir were displayed in his grand gesture of refusing offerings (nadhr) from a Central Asian soldier who was 'helping the enemies of the kingdom'. ${ }^{97}$ The wealth of his takiyya resulted from such attention to affairs of state, and an inventory of its wealth after Shāh Musāfir's attempts to give everything away to the poor still managed to find some 500 rupees. ${ }^{98}$ Yet despite this, the often closely observed details of Shāh Musāfir's own life show the rough and humbling results of the Sufi ideal of personal poverty (faqr) lived out literally and, at times, in extremis.

In spite of his many social duties, Shāh Musāfir was still very much a traveller of the mystical path (tarīqa) of Islam, and the brief surviving accounts of his spiritual states in the Malfüzāt-e-Naqshbandiyya make extraordinary reading. Descriptions of the spiritual experiences of both master and disciples are given at various points in his malf $\bar{u} z \bar{a} t$, including descriptions of the world filling with light, or the experience of the mystical expansion (bast) of the self unto the outer edges of the universe. ${ }^{99}$ Brought into proximity with God through a lifetime of spiritual exertion, Shāh Musāfir is a figure who is unfamiliar from the metaphysical complexity of many modern presentations of Sufi tradition, even though his life expressed the practical outcome of many such esoteric notions in the social world. Although books (almost exclusively hagiographic tadbkirāt of the earlier Naqshbandī saints) played a limited role in spiritual instruction at the takiyya, ${ }^{100}$ there was a firm emphasis on the more active spiritual disciplines of prayer and service. ${ }^{101}$ Their Naqshbandī affiliation did not prevent Shāh Musāfir and his followers from making pilgrimages to the shrines of the earlier Chishtī saints at nearby Khuldabad or, in the case of Shāh Palangpōsh, to Gulbarga. ${ }^{102}$ Whatever rivalry there may have been with other living Sufis from different orders in Awrangabad, the sacred geography associated with the region's earlier (and dead) Sufis seems to have been deliberately resorted to for the purpose of meditation and the acquisition of increased spiritual power. One of Shāh Palangpōsh's followers, Mīr 'Abd al-Qādir, later spent a night in a characteristically Naqshbandī meditation ( $\mathrm{khatm}$ ) beside his master's grave in Awrangabad, a practice that was undoubtedly common. ${ }^{103}$

The embeddedness of Shāh Palangpōsh and Shāh Musāfir in the social affairs of their clientele is perhaps most clearly typified by their demanding of offerings ( $n a d h r$ ) as the rightful price for their intercession against impending misfortune (balā). The demanding and offering of nadbr had many different forms both in courtly and Sufi contexts. Even by the late nineteenth century, it was still the custom of the governor 
(sūbedār) of Awrangabad to march in company twice per year to the Nawkhanda palace of the Nizāms (Figure 1.2), hard by the takiyya of Shāh Musāfir, to formally offer nadhr to the Nizām. The offering of nadhr at court in Haydarabad continued to form an important source of income to the Āsaf Jāh rulers until the twentieth century. ${ }^{104}$ While demanding nadhr was therefore not a uniquely Naqshbandī or even Sufi practice, the Naqshbandī tradition in Awrangabad nonetheless placed emphasis on it, which helped enrich the takiyya under the leadership of Shāh Musāfir's successor, Shāh Mahmūd, in whose Malfūzāt-e-Naqshbandiyya the accounts of the importance of offering nadbr were presented. It is in the practice of the demanding of nadbr, with the many graceful or alarming consequences described in the shaykhs' malfüzāt, that the trajectories of their inner and outer lives, their significance as both spiritual and social actors, is most clearly seen. ${ }^{105}$ For while the quiescent flourished, those negligent of paying their dues were driven to insanity or death. Amid the breathing and sometimes brutal circumstances of life in the Mughal city, the abstractions of the spiritual theory of the Sufis and the sovereignty of its sublime states did not entail a retreat from the surrounding world, but at times instead a calamitous leap into the affray.

Neither Shāh Palangpōsh nor Shāh Musāfir were literary-minded theoreticians of even the most modest kind, and their importance for our understanding of the Sufi

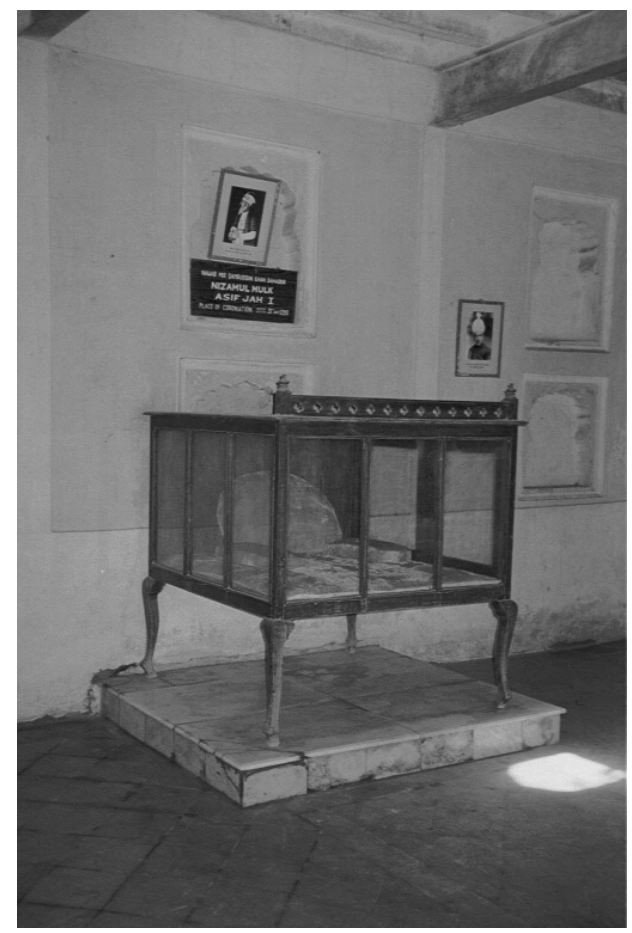

Figure 1.2 Throne (masnad) of Nizām al-Mulk at Nawkhanda Palace, Awrangabad. 
past lies in this very distinction from their literary cousins. To relegate them to the marginal status of provincial dilettantes is, however, to miss the wider point. The anecdotes preserved in their hagiography show a familiar acquaintance with the vocabulary and practices of Naqshbandī Sufism as it had been formulated in its Central Asian homeland. The contrasting mystical states of contraction (qabz) and expansion (bast) were clearly recognized by Shāh Musāfir in his followers, ${ }^{106}$ and, if it was far from a matter of daily discussion, there was at least one conversation on the theory of the Unity of Being (wabdat al-wujūd) recorded in the Malfüzāt-eNaqshbandiyya. ${ }^{107}$ Specific forms of meditation (dhikr), rules of ceremonial and seemly behaviour (adab), and perhaps most vividly the emphasis placed upon the practice of inner 'concentration' (tawajjuh), were practised in the midst of the day-today activities of the shaykhs among their varied clientele. These practices were often directed towards their clients' practical needs, for example in the recovery of stolen goods. ${ }^{108}$ In the use of such transcendental techniques in the solution of the morass of everyday problems of human life, such Sufis do not lose their heaven-sent superiority. Instead, they reveal solidarity with the mundane travails of the human condition; and in doing so, the Sufis gain a far deeper humanity.

With its Central Asian character, its more or less specifically Naqshbandī practices and its readings from the lives of the earlier Naqshbandi saints, the circle around Shāh Musāfir was very conscious of the heritage of its Central Asian lineage. Yet on the evidence of the Malfīzāt-e-Naqshbandiyya, the Awrangabad Naqshbandīs seem to have been oblivious to the developments in Naqshbandī thought and practice associated with the Naqshbandī 'renewer' Ahmad Sirhindī and his followers in India during the preceding generations. ${ }^{109}$ This is perhaps more revealing about the scale of Sirhindī's influence in Mughal Sufi circles than it is about the provinciality of Awrangabad, for Sirhindī's early influence has perhaps been overestimated. While Sirhindī's followers were present in the imperial camp at Awrangabad during Shāh Musāfir's lifetime, ${ }^{110}$ they were either unnoticed or deliberately ignored by the better-established circle gathered in the city around Shāh Musāfir. Despite the role that Sirhindī's thought would play in Naqshbandī circles in Delhi a few decades later, the evidence of the Malfūzāt-e-Naqshbandiyya suggests that it either made little impact on the circle of Shāh Musāfir or was deliberately ignored. ${ }^{111}$

This attitude may have reflected the controversy around Sirhindī's ideas. Awrangabad had earlier played an important role in the discrediting of Sirhindi's thought and the acquisition of the learned opinions from scholars in the Hijaz that led to the banning of Sirhindī's letters in the Mughal domains. In 1090/1679, the imperial shaykh

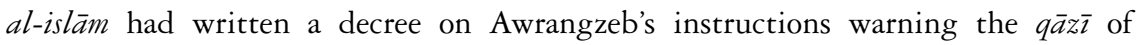
Awrangabad about the dangers of Sirhindī's followers. The decree asserted that some of the teachings contained in Sirhindī's collected letters (maktūbāt) were contrary to the principles of the Sunna, and that since the followers of Sirhindī were known to be actively spreading his teachings in Awrangabad, the $q \bar{a} z \bar{\imath}$ of the city should do his best to thwart and punish them. ${ }^{112}$ Since this decree did not seem to have been entirely successful, in 1093/1682 Sirhindî's opponents subsequently wrote to the Hijaz to request the opinions of the 'ulama of the holy cities on certain aspects of 
Sirhindī's teachings. They replied that Sirhindī was surely an infidel, as made clear in the Qadh al-zand of the Madinan scholar Muhammad ibn 'Abd al-Rasūl al-Barzanjī. ${ }^{113}$ In Mughal Awrangabad, many of the opinions and legal rulings ( fatāwa) given against Sirhindī were collated in $1094 / 1683$ by the Indo-Afghan migrant, 'Abd Allāh Khwēshgī of Qasur (d. after 1133/1720), in his Mukhtasar $M a$ ärij al-wilāya. ${ }^{114}$ The disavowal of Sirhindī's doctrines later continued to play a part in Awrangabad's circles of religious learning during the period of the composition of the Malfuzatat-e-Naqshbandiyya, as testifed by the existence of a manuscript of al-Barzanjî̀s refutation of Sirhindī's teachings that was copied by one of his own descendants in Awrangbad in 1157/1744. ${ }^{115}$ Given the scale of controversy over Sirhindī's teachings that Mughal Awrangabad witnessed, it seems highly unlikely that Shāh Musāfir and Shāh Palangpōsh would have been unaware of the existence (if perhaps not the details) of this much-maligned fellow Naqshbandī. But as we have seen, their Sufism was more inclined towards the social functions of miracle-working and faction- forming among the city's Central Asian (tūrannis) community than the kind of abstract and self-aggrandizing speculation that had earned Sirhindī a bad name. It therefore seems likely that Shāh Mahmūd decided to steer clear of controversy in his hagiography of Shāh Musāfir and Shāh Palangpōsh. He achieved this by avoiding reference to Sirhind̄̄ and painting Shāh Musāfir as what was in contemporary terms a politically and doctrinally conformist figure, whose abundant miracles were nonetheless wrought by little more than the repetition of the opening verses of the Quran.

\section{Nizām al-dīn Awrangābād̄̄}

With the celebrated and literary-minded disciples that were important factors in his later commemoration, the career of Nizām al-dīn reveals a picture of a Sufi tradition at work in Awrangabad that was considerably more alive to the intellectual currents of the day. ${ }^{116}$ Like Shāh Nūr and the city's Naqshbandīs, Nizām al-dīn was originally a migrant to the Deccan from North India, and was born in the region of Awadh around 1076/1665-6. ${ }^{117}$ His precise home was not mentioned in the earliest source relating to his life, Absan al-shamä'il, though the town of Kakori and its nearby village of Nagrawn often feature in later ones. ${ }^{118}$ As a young man Nizām al-dīn travelled to Delhi, which like Awrangabad a few decades later was enjoying a period of royal and aristocratic patronage under the aegis of Shah Jahan that was as beneficial to its Sufis as to its other inhabitants. There Nizām al-dīn came into contact with the followers of the influential Chishtī shaykh Kalīm Allāh Jahānābādī (d. 1142/1729). In part through the influence of Kalīm Allāh's own master Yahyā Madan̄̄ (d. 1101/1689), Nizām al-dīn became the initiate and eventually the favourite of Kalīm Allāh. ${ }^{119}$

Nizām al-dīn spent several years at the khanaqah of his master before setting off for the Deccan under the latter's explicit instructions. ${ }^{120}$ Like Shāh Palangpōsh, Nizām al-dīn then travelled for a number of years with the Mughal army through the war-torn countryside of the Deccan, and Shāh Palangpōsh's martial career may be suggestive of Nizām al-dīn's uncertain activities during these years. The letters sent to Nizām al-dīn at this time from Kalīm Allāh were delivered through the postal 
service of the imperial army. Nizām al-dīn was not unique in his accompaniment of the royal armies engaged in the pacification of the Deccan. For aside from Shāh Palangpōsh's accompaniment of the Mughal armies, two of Nizām al-dīn's co-disciples of Shāh Kalīm Allāh also travelled with the Mughal armies on their conquest of the Deccan Muslim sultanate of Golkonda in the 1090s/1680s. Like Nizām al-dīn in Awrangabad, Shāh Yūsuf al-dīn Qādirīi (d. 1121/1709) and Shāh Sharîf al-dīn Qādirī (d. soon after 1121/1709) then left the army to establish themselves in the newly conquered city, where their tombs together eventually formed one of the most important shrines in Haydarabad. ${ }^{121}$ Nizām al-dīn would also later send several of his followers to accompany the army of Nizām al-Mulk as well. ${ }^{122}$

During his lengthy itinerary through the south, Nizām al-dīn visited several of the cities of the Deccan, including the notable political and Sufi centre of Burhanpur (where his murshid Kalīm Allāh seems to have first wished him to settle), before finally deciding to reside in Awrangabad with his master's blessing, where he remained until his death in 1142/1729. ${ }^{123}$ Nizām al-dīn's connections with the Mughal elites served his purposes well, for upon his arrival in Awrangabad, a Central Asian notable in Mughal service called Kāmgār Khān built the Sufi a khanaqah next to his own haveli in the Shāh Ganj quarter. This Kāmgār Khān later compiled the collection of Nizām al-dīn's 'recorded conversations' (malfüzāt) entitled Absan alshama'il. Shāh Ganj was the centre of the city and the site of its famously wealthy royal market, near the great palace founded by Awrangzeb. Over time, Nizām al-dīn built up a following in Awrangabad that combined a retinue from among the Mughal elite classes with more humble petitioners from across the city. His malfüzāt suggests that there were rarely large numbers of people gathering around him. However, in one amusing anecdote Kāmgār Khān described his master's irritation at the insults and projectiles that were hurled whenever groups of followers gathered for supper at the khanaqah, resulting in Nizām al-dīn's decision to allow the dervishes, like schoolboys in a sweet-shop, only to enter the khanaqah in small groups. ${ }^{124}$ Like his Naqshbandī contemporaries in Awrangabad, Nizām al-dīn was also associated with Nizām al-Mulk, an association which later tradition would adopt in ascribing the latter's military and political successes to Nizām al-dīn's miraculous help. ${ }^{125}$ Following Chishtī sensibilities towards royal friendships, Kāmgār Khān is vague about this association in his malfīzāt, though the fact that Nizām al-Mulk may have composed a devotional life of the Sufi entitled Rashk-e-Gulistān-e-Ihrām is suggestive of a close relationship. ${ }^{126}$ Nizām al-Mulk was also connected with Nizām al-dīn's Naqshbandī contemporaries in Awrangabad, while his predeliction for the company and comfort of dervishes was also noted by one of his early biographers, Lālā Mansārām. ${ }^{127}$ If such a close connection did exist, it remained in the prince's family. For almost forty years after Nizām al-Mulk's death, his grandson 'Imād al-Mulk Ghāzì al-dīn Khān Fīrōz Jang III (d. 1215/1800) composed an important biography of Nizām al-dīn's son and successor, Fakhr al-dīn. And in his lengthy devotional mathnaw̄ poem Fakbriyat al-nizām, also written in honour of Fakhr al-dīn, 'Imād al-Mulk claimed that Nizām al-Mulk underwent a formal Sufi initiation (bay'at) from Nizām al-dīn, so rendering himself a disciple (murīd) of the Sufi. In a vivid image of 
the intervention of men of state in Sufi affairs, the same work also claims that upon Nizām al-dīn's death, Nizām al-Mulk came in grief to the khanaqah to personally appoint Fakhr al-dīn as the successor of his dead father. ${ }^{128}$

During the years between the death of Awrangzeb in 1118/1707 and the formation of Āsaf Jāh autonomy in the Deccan under Nizām al-Mulk two decades later, Nizām al-dīn's khanaqah served as the focus of a cross section of Sufi activities. These ranged from the performance of religious exercises and the devotional recitation of Sufi lives to the redistribution of wealth and the crystallization of reflections on political authority into firmer alliances. ${ }^{129}$ We know from literary anthologies that a number of poets were associated with Nizām al-dīn, including one with the classic Sufi pen name of 'Âshiq ('the lover') who was a disciple of the saint. ${ }^{130}$ At his master's command, 'Âshiq wrote an extremely lengthy moralizing mathnaw $\bar{\imath}$ poem entitled Aslāb-ye-akblāq $\bar{u}$ dīn ('The Improving of Morals and Religion'). 'Āshiq was wellrespected for his learned poetry, which won him many admirers; the great early Urdu poet Walī Awrangābādī seems to have later alluded to his works in one of his poems. The mid-eighteenth-century anthologist Afzal Bēg Qāqshāl also refers to a poet called Mīrzā Turk 'Alī Bēg, with the pen name Wāsil, as one of the disciples of Nizām al-dīn. ${ }^{131}$ Wāsil was said to have been always busy in divine remembrance and meditation (dhikr $\bar{u}$ fikr-e-darwesh $\bar{\imath})$ and to have been a regular attendant at the musical sessions held on Thursday evenings at Nizām al-dīn's khanaqah where, Qāqshāl tells us, there was always much ecstasy (wajd). However, perhaps the most significant literary associations of Nizām al-dīn are those that connect him to Sirāj Awrangābādī (d. 1177/1763), who along with his local contemporary Walī is often regarded as the great founding poet of Urdu. The details of Sirāj's life in Awrangabad were recorded in a number of early Urdu literary anthologies and have been well-known to Urdu literary historians for generations. ${ }^{132}$ From these, we know that Sirāj was attracted to the city's Sufis from an early age, and spent a number of years as an ecstatic dervish, wandering naked and staying in the shrines of neighbouring Khuldabad. He eventually became a disciple of the Awrangabad Chishtī Sufi, 'Abd al-Rahmān (d. unknown), who in time forbade him from writing any more poetry. It appears that Sirāj's master, this Indian 'gentleman from Porlock', was the 'Abd al-Rahmān ibn 'Abd al-Rahīm known to have been one of the followers of Nizām al-dīn. This figure lived close to Nizām al-dīn's khanaqah in Awrangabad, and left a treatise entitled Murīd wa murìd̄̄ ('The Disciple and Discipleship'). ${ }^{133}$ His later command banning Sirāj from composing any more poems is among the most notorious examples of the authority of the master in Sufi history.

As Sirāj's biography shows, pilgrimages to the shrines of the earlier Chishtī saints of the region were regular and important events in the Chishtī circles of Awrangabad. ${ }^{134}$ Nizām al-dīn for his part instructed one of his followers to write a complete guidebook to the shrines of all the Muslim saints and their annual death anniversaries ('arâs). ${ }^{135}$ But despite the reticence of Nizām al-dīn's Chishtī biographers, association with the political rulers of the city and their own rituals also played a role in his life. The Malfüzāt-e-Naqshbandiyya contains a picture of Nizām al-dīn attending (along with Shāh Musāfir) the first death anniversary ('urs) of the recently 
deceased Awrangzeb at the shrine of Zayn al-dīn Shīrāzī (d. 771/1369) at Khuldabad in which the emperor lay buried. ${ }^{136}$ Such attempts to stay on the right side of temporal rulers were not uncommon for influential Sufis, for several Sufis had earlier been executed by Awrangzeb's administration, most famously the ecstatic dervish Sarmad in 1068/1658. There does seem to have been a dispute of some kind between Nizām al-dinn and the royal administration in the city regarding the location of the public musical sessions (mahfil-e-sama $\bar{a}^{\prime}$ ) of which he was a champion. ${ }^{137}$ But Nizām al-dīn was following notable Chishtī precedents in his defence of $s a m \bar{a}^{-}$, not least his predecessor in the Deccan, Gēsū Darāz and his own teacher Kalīm Allāh. ${ }^{138}$ The biographical Absan al-shamā'il of Nizām al-dīn's follower Kāmgār Khān contains many of

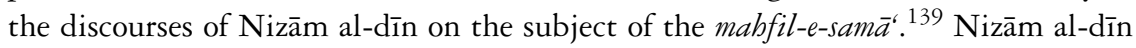
also wrote a Persian treatise entitled Nizām al-qulūb ('Order of the Hearts') on the practice and various techniques of $d h i k r$. The text is notable for its discussion of Yogic methods of breath control and of meditations borrowed from other Sufi traditions, probably a result of Nizām al-dīn's initiation into several orders beside his primary Chishtī affiliation. ${ }^{140}$ In such ways, Nizām al-dīn was very much a perpetuator of the learned tendencies of Chishtī Sufism represented by his teacher Kalīm Allāh. The Nizām al-qulūb in part reflected the Kashkül-e-kalīmī (1101/1690) of Nizām al-dīn's master Kalīm Allāh. The latter book was almost certainly written before Nizām al-dīn left Kalīm Allāh's lodge in Delhi and contains many similarly practical instructions on the different kinds of dhikr. Like Nizām al-qulūb, Kalīm Allāh's work also discussed the benefits of the postures of Yoga (baythak-e-jog $).{ }^{141}$ Nonetheless, the source of Nizām al-dīn's knowledge of such Yogic techniques may also have been more direct, for Kāmgār Khān mentions that several of Nizām al-dīn's followers were Yogis. ${ }^{142}$

What is known of Nizām al-dīn's private-life is also of interest. In contrast to Shāh Nūr, he married twice, albeit relatively late in life, with his first wife coming from the family of the great Deccan Chishtī saint Gēsū Darāz. ${ }^{143}$ Through these wives, Nizām al-dīn had 5 sons and 7 daughters, the latter marrying into the families of local religious and political elites. ${ }^{144}$ Nizām al-dīn thus carved a considerable position for himself amid the many opportunities offered to able Hindustani migrants by the Mughal conquest of the Deccan. Though of obscure parentage himself, his own and his offspring's marriages show how he had risen to the same social class as his master Kalīm Allāh, scion of a notable family of royal architects. ${ }^{145}$ The Sufi orders could also offer their members a career structure with attractive prospects for social betterment. Yet marriage alliances were far from uncommon, and both Chishtīs and Naqshbandīs had earlier intermarried with members of the Mughal royal house itself. ${ }^{146}$ The marriages of both Nizām al-dīn and his daughters reveal how Sufis, no less than any of their contemporaries, lived, loved and married within the classic Islamic model of the agnatic family. Like other models of authority in Islam, that of the Sufis thus drew upon genealogical models of kinship in order to articulate, bestow and ultimately inherit the charisma of the saintly master.

Upon the death of Nizām al-dīn in 1142/1729, his son Fakhr al-dīn was still a child and control of his khanaqah seems to have passed into the hands of one of his deputies (khal̄̄fas), possibly his biographer Kāmgār Khān. Fakhr al-dīn’s education 
in Awrangabad seems to have been very much that of a late Mughal gentleman, and included study of the martial arts and medicine as well as more religious matters. ${ }^{147}$ At the age of nineteen, like other well-born youths of ambition, he joined the army of Nāsir Jang, the successor of Nizām al-Mulk as ruler of the Deccan, and only resigned his post to concentrate on religious matters after several years of military service. ${ }^{148}$ Although Fakhr al-dinn seems then to have returned to Awrangabad for some time, it is likely that with his father's tradition already upheld there by his deputies, a mixture of ambition and the familiar pattern of successional disputes lay behind Fakhr al-dīn's decision to move to Delhi around 1160/1746-7. ${ }^{149}$ We should not forget that Nizām al-dīn's khanaqah had been built on land that had originally belonged to his follower Kāmgār Khān and so it is possible that after the saint's death the property remained in the hands of Kāmgār Khān's family. Whatever the motives behind it, Fakhr al-dīn's move would have important consequences for his father Nizām al-dīn's posthumous reputation. For as the legacy of Nizām al-dīn's khaliffas in Awrangabad disappeared into provincial obscurity, Fakhr al-dīn and his own descendants' central role in the vigorous Sufi scene in Delhi during the mideighteenth and nineteenth century ensured that Nizām al-dīn's reputation would outlive the political and cultural eclipse of his chosen city of Awrangabad.

\section{The literary tradition of the Awrangabad Sufis}

\section{An overview}

As we have seen, the traditions of Shāh Palangpōsh and Shāh Musāfir and of Nizām al-dīn possessed early malfüzāt collections describing the lives and teachings of their saints and these two texts form the primary focus of this section. The genre of the malfüzāt is most closely associated with the Chishtiyya order to which Nizām al-dīn belonged. With his Sufi apprenticeship in Delhi before his move to Awrangabad, Nizām al-dīn stood at an intersection between the strong malfüzāt traditions of the early Delhi Chishtīs and those of the Deccan Chishtīs based primarily at Gulbarga and Khuldabad. This dual heritage is reflected in the malf $\bar{u} z \bar{a} t$ of Nizām al-dīn itself, where the vast majority of anecdotes concerning the wider Chishtī tradition focus on either the early Delhi Chishtīs or upon Gēsū Darāz of Gulbarga. ${ }^{150}$ Details of pilgrimages to the shrines of the Chishtī masters at Khuldabad (especially Burhān al-dīn Gharīb, the prime figure of the Khuldabad textual tradition) similarly give evidence of Nizām al-dīn's integration into the closest to Awrangabad of the early centres of the Chishtiyya. ${ }^{151}$ While malfüzāt collections were composed in India both with reference to later Indian Naqshbandī shaykhs and, with careful dissimulation, also sometimes to the earliest Naqshbandī saints, the anecdotal style of the Malfüzāte-Naqshbandiyya on Shāh Palangpōsh and Shāh Musāfir is closer in style to the tadhkira genre more closely associated with the Naqshbandiyya beyond India than to the classic model of the malfīzāt as a collection of edifying Sufi lectures. Despite these differences in style, both texts are considered here together for the reason that they were written during the same period by direct followers of their respective saints. ${ }^{152}$ 
Both texts were similarly composed a number of years after the deaths of their primary subjects.

The author of the Malfüzāt-e-Naqshbandiyya is known to posterity as Shāh Mahmūd Awrangabādī. Although the stylized humility of his composition affords little room for details of his own biography, it seems that he was either one of the many orphans looked after by Shāh Musāfir at his takiyya or, more probably, a nephew of the saint, as maintained in the oral tradition of his heirs in Awrangabad. Shāh Mahmūd seems from his childhood to have adopted the way of the dervish and so, upon the death of his master (and uncle?) Shāh Musāfir without issue in 1126/1715, Shāh Mahmūd was appointed as the first successor (sajjāda nashīn) of Shāh Musāfir at his Awrangabad takiyya, subsequently known as Panchakkī ('the watermill'). Shāh Mahmūd died and was buried at Panchakkī in 1175/1762. From the picture painted by his text of Panchakkī as an almost exclusively Central Asian enclave during its heyday under Shāh Musāfir, and the likelihood of his belonging to the family of Shāh Musāfir, it is likely that Shāh Mahmūd was also of Central Asian ancestry. This ethnic dimension is important for a number of reasons, for it reflects the role of the cult of the Awrangabad Naqshbandīs as administering to an exclusively Central Asian clientele, whose presence in Awrangabad was concomitant with the city's role as the centre of Mughal expansion in the Deccan. The Malfüzāt-e-Naqshbandiyya gives many snapshots of the Central Asian character of the original fellowship of the Awrangabad Naqshbandīs. None of these is more memorable than the image of Shāh Palangpōsh wandering through the bazaars of the city, hailing people with his cry of 'O crazy one (Ay dīwāna)!' and showing a classic Central Asian proclivity by accosting a seller of falconry gloves. ${ }^{153}$ Shāh Musāfir's choice of a fellow Central Asian as his successor seems to sum up this association between Sufism and group identity conceived in primarily ethnic terms. Here the circle of Shāh Palangpōsh and Shāh Musāfir provides a contrast with what is known of the early associates of Shāh Nūr, who were drawn from the community of people of Iranian descent in Awrangabad. Sufi affiliations seem in this way to have mirrored the social and political divide

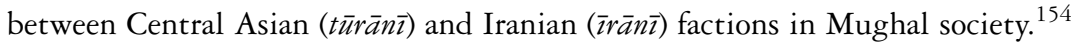

The author of the malfīzāt of Nizām al-dīn entitled Absan al-shamā'il was Kāmgār Khān. It is a fitting illustration of the embeddedness of Sufism in the wider cultural life of the Deccan that the only biographical information to have survived on Kāmgār Khān is found in one of the numerous poetic anthologies written in Awrangabad during the eighteenth century. ${ }^{155}$ This work, the Tuhfat al-shu'arā of Afzal Bēg Qāqshāl Awrangābādī (d. unknown), contains biographical information on scores of poets from the Deccan, and not least those who wrote in Awrangabad during the rule of Awrangzeb and Nizām al-Mulk. It was completed in 1165/1751, around twenty years after Nizām al-dīn's death. It was by virtue of the verses of his own composition that Kāmgār Khān recorded in his Absan al-shamā'il that he was included in Afzal Bēg's anthology. Afzal Bēg informs us that Kāmgār Khān was also known as 'Alī Awrangābādī, and was one of the descendants (awlād) of the great Central Asian Sufi, Khwāja Naqshband. This would suggest that like so many of Awrangabad's residents, Kāmgār Khān was of Central Asian (tūrān̄ $)$ ethnicity. Given the fact that 
the text mentions that Kāmgār Khān was already resident in Awrangabad when Nizām al-dīn arrived from Delhi, it would appear that Kāmgār Khān belonged to the first or (more likely) second generation of türāniss in Awrangabad that had accompanied the Mughals' expansion into the Deccan. What is interesting in this respect is his decision to align himself with a Sufi originating from Hindustan and belonging to the Chishtī tradition rather than with a fellow Central Asian of his own familial tradition of the Naqshbandiyya. In its small way, this association with Nizām al-dīn hints at the wider gradual integration of Central Asian migrants into the Indian world that had earlier seen some of the Mughal rulers themselves shift their allegiance from their ancestral ties to the Naqshbandiyya to the pre-eminent Chishtīs of Delhi.

Afzal Bēg also recorded that Kāmgār Khān was employed in the superintendency of the Mughal imperial court of justice (dārüghagi-ye-'adālat al-'áliya) in Awrangabad. Thus, like many of the followers of the city's Naqshbandīs, Kāmgār Khān was closely connected to the Mughal state. The patronage of Nizām al-dīn's lodge (and subsequent shrine) was in this sense identical to that of Shāh Musāfir, whose own shrine would be beautified by followers in the service of the Mughals and later the independent Nizām al-Mulk. For the Tuhfat al-shu'arā also adds that along with his brother Muhammad Nūr al-dīn Husaynī, Kāmgār Khān built a khanaqah and mosque for Nizām al-dīn when he first arrived in Awrangabad from Sholapur in the southern Deccan, where we know he had been travelling with the imperial army. In line with the other Sufi institutions in the city, an irrigation channel (nehr) was also constructed. According to the Tubfat al-shu'arā, the khanaqah that he built neighboured his own residence in the city, and after the saint's death Kāmgār Khān also built Nizām al-dīn's mausoleum. We also know that Kāmgār Khān was long desirous of visiting the khanaqah of Shāh Kalīm Allāh, the master of Nizām al-dīn. He was finally given permission by his master to make the perilous journey to the north in $1133 / 1720 .{ }^{156}$ He made this journey with his brother Nūr al-dīn, who died en route, and whose body was carried back to Awrangabad to become the focus of one of several subsidiary shrines around the city dedicated to Nizām al-dīn's deputies (khalīfas). While he was in Delhi, Kāmgār Khān compiled a short collection of the recorded conversations (malfūzāt) of Shāh Kalīm Allāh that he entitled Majālis-eKalimin. This text, which he dedicated to the memory of his brother, is usually found bound into one volume with the Absan al-shamä'il. This theme of fraternal dedication seems to be surreptitiously continued in the Absan al-shama' ${ }^{\prime} l$, where Nūr al-dīn features in almost as many of its anecdotes as Nizām al-dīn himself, suggesting a subtext of brotherly as much as saintly memorialization. The date of Kāmgār Khān's death in Awrangabad is not mentioned in the Tuhfat al-shu'ara, though due to his prestige as a text-producer his grave - like that of his Naqshbandī counterpart Shāh Mahmūd - was revered and has survived to the present day.

Writing at the same time, in the same city and broadly on the same subject as Kāmgār Khān, Shāh Mahmūd drew instead upon a literary tradition that flourished outside of India around the earlier Timurid literary centre of Herat and was written in memory of the saints of the Naqshbandiyya. In the case of Kāmgār Khān, readings 
and sources seem similarly defined in terms of geographical location and affiliation to a specific Sufi order. The importance of Kāmgār Khān's journey to Delhi and its literary efflorescence lies in the sense of continuity it established with the Chishtī literary tradition of Hindustan. Apart from the Kìmiy $\bar{a}^{\prime}-y e-S a^{\prime} \bar{a} d a t$ of al-Ghazāli (d. 505/1111) for which, judging by its regular recurrence, Kāmgār Khān seems to have possessed a special affection, almost all of the hagiographical texts referred to by Kāmgār Khān (such as the Manāqib-e-Chishtiyya) were concerned with the lives of the earlier Chishtī saints. ${ }^{157}$ Just as the geography of the source texts of the Malfüzāt-eNaqshbandiyya points beyond the Deccan and northwards to Herat and Central Asia, so the source text and narrative geography of the Absan al-shama'il bears a northerly axis centred mainly on the earlier Chishtī heartland of Delhi. It is in this sense that the journey of Kāmgār Khān to Delhi takes on a special significance, for it represents a journey to the source of his literary no less than his spiritual inspiration. It is also one which, despite its own long and varied literary traditions, says much about the status of the Deccan vis-à-vis Delhi and the other early Chishtī centers of Hindustan among the new generation of Chishtīs residing in the Deccan. The memory of Delhi, and a firm sense of belonging to its cultural orbit, thus continued to occupy the mental world of the circle of the North Indian Sufi migrant, Nizām al-dīn.

An earlier tradition of Naqshbandī and Chishtī sacred biographies thus formed the literary background of the two texts. These earlier and distinct traditions may have been responsible for some of their stylistic peculiarities. For stylistically the Malfīzāt-e-Naqshbandiyya looked to the earlier Naqshbandī memorial tradition of Kāshifī and Jāmī in forming its idea of how a Sufi biography should take shape. ${ }^{158}$ Both these authors had also been major models and sources for the Hasanāt al-abrār, a hagiography of the Indian Naqshbandī-Mujaddidīs written in northern India at the turn of the eighteenth century by Muhammad Murād. ${ }^{159}$ The malfüzāt composed by Kāmgār Khān, by contrast, more closely followed the structure of such other earlier Chishtī malfūzāt as those of Nizām al-dīn Awliyā of Delhi or the Chishtīs of nearby Khuldabad, with which Kāmgār Khān may have been familiar.

In comparing the two texts, one primary point of contrast is of the status of Persian as a vernacular mother tongue or as an acquired language of high culture and instruction. There was a clear sense of Persian as the mother tongue of its Central Asian subjects in the Malfiuzatt-e-Naqshbandiyya, as reflected in the idiomatic usages that give the text its distinctive style. But in the Absan al-shamä'il, Persian was clearly conceived and used as a learned language of literary composition and instruction. This is similarly reflected in the more formal and standardized prose style of the text. In the case of the Malfüzāt-e-Naqshbandiyya, Persian clearly functioned as the spoken language of a fellowship of disciples and associates of the Panchakkī shaykhs who clearly drew the boundaries of their community in ethnic terms based on a shared Central Asian identity. The Āsaf Jāh family dynasty, as initiated in India by the Central Asian immigrant and frequent character of the Malfüzāt-e-Naqshbandiyya Fīrōz Jang, shared with the Mughals both a Central Asian ancestry and sense of selfidentity. In the Absan al-shama'il, however, the use of Persian clearly carried no suggestion of or association with a specific ethnic identity and was employed rather 
as a learned language of sophisticated and literary expression. In this alternative framework, it was neither birth nor ethnicity that was requisite to the use of Persian, since the factor was rather education.

\section{Imperial geographies: political visions in the texts}

As modern readers we must be wary of projecting later cultural and political geographies back into the past. For prior to as well as during the eighteenth century, the Deccan was very much felt to be a different country from the Hindustan (i.e. northern India) of Awrangabad's imperial Mughal elites and was explicitly defined as such. While 'foreigners' (āfāqus) had long flourished in literary and political circles in the pre-Mughal kingdoms of the Deccan, the Mughal conquests and the continuance of their imperial claim to the Deccan through the presentation of the $\bar{A}$ saf Jāhs as their viceroys, redefined the Deccan in ways that are easily blurred from a distance of centuries. These re-definitions included such religious dimensions as the decline of official Shi' ism and the reintroduction of Sufi orders attached primarily to the northern Sunni world, alongside such ethnic dimensions as the influx of Central Asians and Afghans to the Deccan. ${ }^{160}$ However, perhaps the most vivid dimensions of cultural change were the political and geographical changes that redefined the relationship of the Deccan to Hindustan within the framework of the Mughal imperium and the religious geography of the north.

If Persian literature was in itself no stranger to the Deccan, it is important not to ignore the cultural changes that the Mughal conquest of the Deccan brought with it. ${ }^{161}$ Like the saints whose lives they portray, the Awrangabad texts were not alien to the Deccan because of their connection with the Persian language and its literary forms. Rather, as a lingua franca of an aligned cultural geography that stretched from the Deccan to Anatolia, it was Persian that very much represented the common ground between the learned newcomers and the older inhabitants of the Deccan. What was new and alien to the Deccan in these texts was rather the image that they expressed of the new cultural and political order initiated by Awrangzeb's conquests of the Deccan kingdoms.

The Persian historiographical tradition in India is replete with accounts of Sufi saints, the significance of which often baffled early British translators into wholesale omission. So in turn were political events and their makers counted within the remit of Sufi writings. Such were the similarities between the textual traditions of kings and Sufis in Awrangabad that direct cross-references often occurred. Not least among these was a common stock of characters and events shared between the Sufi texts and political histories of the period such as the Sāqī Must'ad Khān's Ma'āthir-e-'Ālamgī rì and Khāfī Khān's Muntakhab al-Lubāb. The Malfüzāt-e-Naqshbandiyya contains several long sections and numerous asides in which the major political events of the day that form the stock-in-trade of the contemporary historians are discussed. It is into this sequence of political events that various followers of the Naqshband $\overline{1}$ shaykhs as well as Shāh Palangpōsh himself were placed by Shāh Mahmūd. ${ }^{162}$ Such cross-overs suggest that the literary separation of the religious and the political was 
something reflected into the study of Sufi texts from a European perspective rather than one that was in the same way meaningful among readers in premodern India. This is not to reaffirm clichés about the union of the political and the religious in Islam, but merely to point out that even the most mystical of texts could be firmly embedded in the contexts of their composition.

The similarities between the malfüzāt and their textual contemporaries in Awrangabad were as much in style as in content, for the genre of the recorded conversation was a less uniquely Sufi literary format than is often imagined. Just as Sufis adapted the literary styles of the court in the evolution of their rich poetic tradition, the case seems to have been broadly similar with regard to their prose models. The recording of the edifying speeches and bon mots of princely gatherings was known in Cairo before its manifestation in Chishtī circles in Delhi, for example, and was no less a tradition at the courts of Muslim rulers in India, where Sufi and princely texts often shared the same generic titles, such as majalis ('sittings'). ${ }^{163}$ In Awrangabad, the notable deeds and choice sayings of no less a figure than Nizām al-Mulk (who re-appears throughout the Awrangabad saintly traditions) were collected by the eighteenth-century bureaucrat and historian Lālā Mansārām in his Ma'āthir-e-Nizāmin in a form closely reminiscent of the Sufi texts. ${ }^{164}$ Similar collections, however, were a common enough feature of Persian literature under Mughal courtly patronage in India, not least in the official imperial biographies ( $p \bar{a}$ dishāhnamas), though many other such biographies were also produced. What this wider literary context reveals is that just as Sufis and their shrines had far wider social roles than the 'purely' religious, so to no lesser an extent did the literature which evolved around them partake in its own cultural and political contexts. Sufi and political texts did not so much borrow from one another's distinct spheres, but were rather both part of a wider literary and cultural ecumene in which kings and saints shared centre-stage together.

Both the Malfüzāt-e-Naqshbandiyya and the Absan al-shama'il contain a vision of the Deccan's geography drawn from their mutual connections with the political and cultural world of the Mughal rulers of Hindustan. Members of the Mughal royal house had themselves written biographies of Sufi saints during the period of the Awrangabad Sufis, including Dārā Shikūh's Safīnat al-Awliyā on members of the Qādiriyya and the Mu'nis al-Arwāh, a hagiography of Mu'īn al-dīn Chishtī by Dārā's sister Jahānārā. The most illuminating image of this interconnectedness of the representatives of Sufism and empire to be found in either of the Awrangabad texts is the Malfüzät-e-Naqshbandiyya's only description of an encounter between the city's Naqshbandī Sufis and Nizām al-dīn. In this passage, we read of a shared visit by Shāh Musāfir and Nizām al-dīn to pay their respects at the first death anniversary ('urs) of Awrangzeb beside his simple tomb in the shrine of Zayn al-dīn Shīrāzī (d. 771/1369) in Khuldabad. ${ }^{165}$ The sense of partisanship with the representatives of empire that their special invitation to the gathering suggests is one of the most deliberate and self-evident characteristics of the Malfüzāt-e-Naqshbandiyya. Shāh Mahmūd is not ashamed to show off the Awrangabad Naqshbandīs' friends in high places. For in the text Shāh Palangpōsh is portrayed as the supernatural protector and inveterate companion of Fīrōz Jang, the principal general of the Mughal armies in the Deccan, 
while a large proportion of the followers of both saints were soldiers and officers associated with the Mughal war effort. More generally, the shaykbs are seen to administer to an exclusively Central Asian (türān $\bar{\imath}$ ) constituency, an ethnic bias that was immensely significant in a city acting as the chief outpost for the conquests of a dynasty with close public and private connections with Central Asia. ${ }^{166}$

Shāh Mahmūd's text reveals a picture of its subjects' sense of their spiritual and cultural heritage, pointing in the process to their sense of territory and geographical belonging. This may be seen in the references made in the Malfüzāt-e-Naqshbandiyya to an earlier tradition of Naqshbandī saints, in the mentioning of earlier Sufi texts used at their takiyya in Awrangabad or else in direct references to specific grand figures of the Naqshbandī past. The names dropped of these earlier saintly grandees, as well as the hagiographies mentioned that described them, all belonged to lands far beyond the limits of the Deccan and even of Hindustan. With its special focus on the Herat of Wā'iz Kāshifī ( fl. 906/1500) and 'Abd al-Rahman Jāmī (d. 898/1492), the narrative geography of the sacred glimpsed in these references was one no less associated with the imperial origins of the Mughals in Herat and Central Asia. For as described in the Malfüzāt-e-Naqshbandiyya, the world within which the many followers of the Awrangabad Naqshbandīs moved was one that revolved around the north-south axis of Mughal geography. Gone was any sense of the earlier cultural and political alignment of the Deccan with Shi'ite Persia and the vivid interchanges between the rival cities of the Deccan itself. In the many travel narratives recounted by Shāh Mahmūd, this older geography was replaced by a series of northerly itineraries in which the saints and their followers moved between the cities of the wider Mughal-Timurid world, between Delhi, Kabul and Samarqand. ${ }^{167}$ The accounts of these journeys functioned within a rhetoric that placed a symbolic as much as an historical value on such details. It is little surprise that Shāh Mahmūd saw nothing inappropriate in recounting the dealings of Sufis with the soldiers of empire, for both parties saw themselves as sharing a common geographical, cultural and even spiritual genesis that united the cities of Transoxiana, the classic hagiographical models of Timurid Herat like Jāmī's Nafahāt al-Uns and the great spiritual lineage of the Naqshbandiyya that now tied distant Bukhara to the Deccan.

The picture painted of royal associations in the Absan al-shamä'il is more subtle. For the most part, the text preserves the picture of Chishtī antipathy to the possessors of temporal power just as the Malfüzāt-e-Naqshbandiyya seems to confirm the Naqshbandī penchant for becoming saintly éminences grises. Chishtīideals and rhetoric aside, the earlier history of the Chishtiyya shows their affinity with Hindustan and how their order had already come close to the centre of the Mughal empire during the reign of Akbar. Akbar's close connections with the order may have been born from a sense of shared destiny with a fraternity born in the hinterlands of Timurid Herat but brought to glory only in India, and the connections formed between the royal palace and the Sufi lodge during his reign continued steadily under Jahangir. ${ }^{168}$ These ties were cemented through several generations of royal Mughal pilgrimage to and patronage of the official cradle of the Chishtiyya at Ajmer. ${ }^{169}$ The historian Khāfī Khān later described Awrangzeb making a pilgrimage to Ajmer to thank 
Mu'īn al-dīn Chishtī for his help in defeating Dārā Shikūh, while Sāqī Must'ad Khān described the emperor's many pilgrimages to the Chishtī shrines of Qutb al-dīn in Delhi and Gēsū Darāz at Gulbarga as well as that of Mu`īn al-dīn. ${ }^{170}$

However, it is likely that both the Naqshbandī and Chishtī positions towards imperial elites often reflected a form of public rhetoric as much as a true mirror of more subtle motivations. A letter sent to Nizām al-dīn from his master Kalīm Allāh urges him not to worry about avoiding friendships with the wealthy (dawlatmandān), explaining that such associations can be beneficial for the Sufi in a number of ways. ${ }^{171}$ While the tone of the letter suggests the sincerity of Nizām al-dīn's desire to minimize official or royal friendships, the spiritual and cultural Weltanschaunng reflected in his malfūzāt suggests a more complex picture. For woven into Kāmgār Khān's account of Nizām al-dīn are stories, often heard from the mouth of the saint himself, concerning the dealings (or avoidance of dealings) of the Chishti 1 saints of Delhi with the old Muslim kings of the city. For the most part, these accounts refer to the earlier Chishtī lineage centred on Nizām al-dīn Awliyā of Delhi (d. 725/1325), though another category refers to the deeds of saints connected to Nizām al-dīn Awrangābādī's origins in Awadh, particularly the deeds of Mīr Sayyid Muhammad Qanawjī. ${ }^{172}$ The latter heals the sick sūbedār of Qanawj and is eventually visited by the vizier of Shah Jahan. Shah Jahan later spreads his fame and begs him without success to join the ranks of his government. ${ }^{173}$

The main references to the cultural geography of the Deccan that enter the text in this way are to the Chishti $\overline{1}$ tradition at nearby Khuldabad. ${ }^{174}$ However this tradition too, like the circle around Nizām al-dīn in Awrangabad, had been a first-generation transfer of a Delhi tradition to the Deccan. These similarities between this neighbouring (albeit more sanctified and better established) Chishtī tradition at Khuldabad and Nizām al-dīn's own claims to mystical knowledge and authority were far from lost on Kāmgār Khān. For like the Khuldabad Chishtīs and their own extensive corpus of malfüzāt, the Absan al-shama'il described the gatherings around a master whose legitimacy was based on his connections to Delhi and positioned this master in a wider lineage of saints heralding from Delhi.

No less than the earlier hagiographers of the Khuldabad Chishtīs, Kāmgār Khān therefore constructed his subject's claims to knowledge, authority and the sacred in terms of a spiritual geography centred on the old imperial capital of Delhi. ${ }^{175}$ This was achieved through the combination of Nizām al-dīn's recounting of traditions concerning the early great Chishtī masters of Delhi with the fact of his own initiation in that city at the hands of Shāh Kalīm Allāh. As in the case of the earlier generation of Deccan Chishtīs based at Khuldabad, it was to be understood by the reader of the text that the Deccan was there for a Hindustani master residing in Delhi to give away. This was seen in a letter written to Nizām al-dīn by Shāh Kalīm Allāh granting him spiritual jurisdiction (walāyat) over the entire Deccan. ${ }^{176}$ Both the Khuldabad and Awrangabad Chishtī traditions had arrived in the Deccan travelling either in the wake or in Nizām al-dīn's case in the actual van of the armies of the north. Whatever the personal feelings of the living Nizām al-dīn towards temporal rulers or the traditional rhetoric of the Chishtī order more generally, the literary 
Nizām al-dīn created in the text of Kāmgār Khān was crowned with the imagery of authority and prestige drawn from his associations with the spiritual and political geography of the north as presented through the narratives he recounted in the text of the heroic deeds of the saints and kings of Hindustan.

It is perhaps unsurprising that the two major Sufi groups in Mughal Awrangabad belonged to traditions with historical connections to the city's new northern rulers. Other new-coming Naqshbandī and Chishtī groups were also able to establish themselves in the Deccan in the wake of the Mughal conquests, particularly in the more pacified regions of the northern Deccan. Like the Awrangabad Sufis, Shāh 'Ināyat of Balapur (d. 1117/1705) was also a migrant to the Deccan, having originated of a Central Asian $(t \bar{u} r \bar{a} n \bar{\imath})$ family resident in Punjab before moving to the Deccan in 1059/1649. A land grant (jāgir ) was later given to him in 1072/1661 by Awrangzeb, funding the construction of an ornate khanaqah on the outskirts of Balapur. While this order had few direct connections with the Awrangabad Naqshbandīs, the re-vitalization of Chishtī fortunes in the Deccan owed a more direct debt to Nizām al-dīn. His follower Shāh Ismā̄̄il (d. unknown) went on to found a Chishtī tradition at Ellichpur in the northern Deccan through the work of his own disciple Ghulām Chishtī (d. 1210/1795). ${ }^{177}$ Ghulām Chishtī corresponded with the followers of Nizām al-dīn in Awrangabad and was especially influenced by Nizām al-dīn's meditational textbook, Nizām al-Qulūb. Other followers of Nizām al-dīn migrated to Haydarabad as well as Delhi in the years after Awrangabad's eclipse in the late eighteenth century.

The connections between Naqshbandī and Chishtī Sufis and the Mughals drew on a common heritage formed during the previous five centuries of Muslim rule in India that had often brought Hindustan together more closely with Central Asia than with the Deccan. In the overlapping of saintly and political geographies seen in Sufi as well as royal texts, these common threads were woven together in the creation of a territorial vision of cultural, political and spiritual contiguity. For territory of residence and territory of belonging were by no means necessarily the same in premodern Islamic societies. It was in a common sense of belonging and orientation in the Mughal-Timurid world, this sense of shared origins, that the Sufi texts of Mughal Awrangabad may in part be considered manuals of spiritual colonization, for they provided a territorial vision in part alien to the Deccan of the period. Just as the kings of this world had conquered the material landscape of the Deccan, in their importing of traditions of saintly power from Hindustan and beyond, the Awrangabad Sufis were involved for their part in a process of the spiritual conquest of an earlier Muslim sacred geography. ${ }^{178}$ As recent studies on Islamic Western Asia show, this was far from the first instance of the re-formulation of a Muslim sacred geography incumbent upon the replacement of one Muslim dynasty by another. ${ }^{179}$

As the culture of the Deccan slowly changed after the era of the Mughal conquests, people of the region came to address their prayers to the new saints from the north no less than they paid their taxes to the northern rulers who had heralded the saints' southern migration. As we have seen, migration was the key to the cultural and religious changes heralded by Sufis in the Deccan, an index that was amplified by the writings produced by these Sufi migrants in Awrangabad. It is therefore fitting that 
the earliest Sufi hagiography that we know to have been written in Mughal Awrangabad recorded the lives of the Afghan saints of Qasur in Punjab. ${ }^{180}$ This text, Akbbār al-Awliya, was composed in Awrangabad in 1077/1666 in honour of the Sufis attached to the Khwēshgī clan by 'Abd Allāh Khwēshgī Qasūrī (d. after 1133/1720). Like other Sufi devotees in military service, Qasūrī had travelled to the Deccan in the company of the Afghan notable Jalāl Khān Dāūdzāì. His heart and memory, however, remained tied to the north. The writings of Awrangabad's subsequent Chishtī and Naqshbandī circles clearly echoed this sense of displacement and it was one that would continue well into the Āsaf Jāh period. The same devotion to the distant saints of Hindustan rings through the Ma'āthir al-kirām that Ghulām 'Alī Āzād Bilgrāmī (d. 1200/1786) wrote in commemoration of the Sufis and other notables of his ancestral home of Bilgrām. Ironically, it seems to have been in the shrine of Shāh Musāfir at Awrangabad that this book was written, which perhaps explains the incongruous inclusion of Shāh Musāfir and his master Palangpōsh within its pages. ${ }^{181}$

Through the spiritual conquests of the Sufis of the north the saintly geography and saintly literature of the Deccan was adapted to fit the cultural identity of the Deccan's new rulers and residents, a cultural identity based itself upon a northerly geography and introduced to the south by the Mughal conquests. Sufi lineages (silsila) no less than the genealogies of kings reached in this way towards the same northerly direction, out of the Deccan and through Delhi to the old centres of Chisht, Samarqand and Bukhara. Through their references to the earlier saints of Hindustan and Central Asia and the pilgrimage sites associated with them, the Awrangabad texts were able to both reflect and reify the sense in which saintly and imperial geographies mirrored one another.

From a purely literary perspective, the texts of Shāh Mahmūd and Kāmgār Khān reflect the sense in which Awrangabad had become a northern literary school in the Deccan by the $1140 \mathrm{~s} / 1730$ s. Just as there is no book that was actually authored in the Deccan mentioned as being read by the followers of Shāh Musāfir in Malfūzāt-eNaqshbandiyya, the Absan al-shamä'il similarly shows a world of books aligned almost exclusively to Hindustan and Persia. One of the very few remnants of the Deccan's earlier textual ecumene to be mentioned by Kāmgār Khān is a book by Gēsū Darāz (d. 825/1422) of Gulbarga. ${ }^{182}$ Yet this was characteristic of wider literary changes in Awrangabad. The city's Mughal heyday had attracted writers of many descriptions, including several poets of major importance and literary production in the city flourished due to its position as the sole major centre of patronage in the Deccan. One result of imperial patronage in Awrangabad was the compilation of the great legal compendium known as the Fatāwā-ye-'Álamgī $\bar{\imath} .{ }^{183}$ Literary production also later took place within the Awrangabad shrines themselves, and the great eighteenth century man of letters Āzād Bilgrāmī (d. 1200/1786) later wrote two Sufi biographies (tadhkirāt) while living for seven years in the shrine of Shāh Musāfir. ${ }^{184}$ Around him there gathered at the shrine a large number of his literary followers, some of whom, like Shāhid Mullā Bāqir (d. 1178/1764), chose to live there with him.

Despite the considerable productivity of writers in Awrangabad, the pull of Delhi remained strong and a notable literary circle gathered there around the 
emperor's sister Jahānārā. ${ }^{185}$ Between the death of Awrangzeb in 1118/1707 and the settling of the Āsaf Jāh court to the important royal business of cultural patronage several decades later, many of the writers who had gathered in Awrangabad (including the poet Walī) moved from the Deccan to Delhi. Later the poet Mīr Shams al-dīn Faqīr Dihlawī (d. c.1180/1767) migrated from Delhi to Awrangabad in search of patronage around 1140/1727, only to return to Delhi with his new patron Qizilbāsh Khān as the fortunes of his adoptive city slipped into eclipse by Delhi. ${ }^{186}$ Others, however, remained to leave a permanent imprint upon the post-Mughal literary culture of the Deccan. The literature that was being produced in Awrangabad at this time and among which the Sufi texts must be situated represented substantial changes from the texts sponsored by the independent kingdoms of the Deccan, in many cases in terms of the very medium of language no less than the message it contained. ${ }^{187}$ One major long-term casualty of this re-allocation of patronage was the fragile cultural and linguistic synthesis attempted by poets writing in Dakhani (in Bijapur in particular). But the casualties were as much by region as by linguistic or literary style and historians of the period describe in vivid terms the desolation to which Bijapur in particular was rendered. ${ }^{188}$ One of the most poignant images of this is the post-conquest career of the Dakhani poet Qāzī Mahmūd Bahrī, the Sufi mentor of the last ruler of Bijapur, Sikandar 'Alī Shāh, who spent years wandering the Deccan countryside shorn of home and patronage after the fall of his native city. ${ }^{189}$ Upon the conquest of Bijapur, Bahrī fled first to Haydarabad, which had yet to be conquered by the Mughals. There in the early years after the fall of Haydarabad he was still able to find a patron for his Dakhani poetry, and in 1112/1700 he wrote his Dakhani poetic masterpiece, Man Lagan. But bereft of patronage once again he was forced to leave Haydarabad and to travel to Awrangabad. It seems to have been in Awrangabad that Bahri decided in 1116/1705 to compose the Persian rendering of his Man Lagan that he entitled 'Arūs-e-'irfän. ${ }^{190}$ The latter work comprised long prose sections interwoven with a variety of poems (in qat'a, ghazal and mathnaw form), describing the mystical journey towards gnosis ('irfān) through an extended series of metaphors based around the erotic imagery of the bride. Despite this mystic exposition, Bahrī also managed to weave aspects of his own spiritual and professional biography into the text, including his previous service of Sikandar in Bijapur (now rendered as Sikandar Khān and not Shāh), his sojourn in Haydarabad and his final state of wandering exhaustion and misery. ${ }^{191}$ But no less than in the tone of its final poems, in the very raison d'être of 'Arüs-e-'irfān we hear poignant echoes of the human effects of the shifts in patronage that were incumbent upon the coming of the Mughals. For it was through the arrival of the Deccan's conquerors from North India and beyond that Bahrī was forced to abandon his original poetic medium of Dakhani and translate his work into Persian in the hope of finding a new and appreciative audience. Whatever his success, he eventually left Awrangabad to return to his home village of Gogan, near Bijapur. On the journey through what was still an unsettled region, he was robbed and lost his own copies of the manuscripts containing all of his verses. He died and was buried in Gogan in 1130/1718. 
Literature, then, carried discrete traces of the Deccan's political history. The many tadbkira writers who recorded details of the poets and notables of Mughal and Āsaf Jāh Awrangabad show a literary and aristocratic culture closely associated with the geography, customs and language of Delhi. This may be seen in the Chamanistān-eShu'arā of Shafīq Awrangābādī (d. 1224/1808), the Ma'āthir al-Umarā of Shāh Nawāz Khān (d. 1171/1758) or perhaps most clearly in the fact that Dargāh Qulī Khān (d. 1180/1766), the writer of the Risāla-ye-Sälär Jang (more famous as the Muraqqa'$e-D i l h \bar{\imath})$ was himself a resident of Awrangabad who travelled to Delhi in the company of Nizām al-Mulk. If in some senses derivative, the literary scene in Awrangabad was also energetic and creative, not least in the realm of Urdu. But from the period of the Mughal conquest of the Deccan, the sense of the Deccan as a separate literary domain from the cultural world of the north effectively disappeared. The possibility of such patronage seems the most likely reason why, like so many other providers of cultural and spiritual splendours, Sufi masters chose to settle in Awrangabad at all rather than live itinerant lives of freewheeling poverty or efface themselves in provincial obscurity. But a generation later, in the case of Mawlānā Fakhr al-dīn (d. 1199/1785), the son and successor of Nizām al-dīn, and many of the followers of Shāh Musāfir, the disappearance of this patronage led many of the city's Sufis to leave Awrangabad for Delhi. The Sufi scene that developed in Delhi in the mid-eighteenth century was connected to the Deccan in more ways than merely the fact of Fakhr al-din's migration. For it was in the great madrasa founded in Delhi by the great Deccan general Fīrōz Jang that Fakhr al-dīn set up his new khanaqah on his arrival in Delhi. ${ }^{192}$ A scene perhaps hard to associate with the usual quietist picture of Chishti tendencies, it was one of Sufi life supported by the spoils of conquest. In a strange shadowing of itineraries, south and then back north, this great madrasa also became the place of gathering for the followers of the Awrangabad Naqshbandīs who also left the city for Delhi after the death of their masters. Two of the disciples of the Awrangabad Naqshbandīs, Shāh Khākī and Shāh Shīdā, actually taught in the madrasa, while others simply stayed there when they were in Delhi. ${ }^{193}$ Such close connections with one of the main soldiers of empire shows not only the importance of sub-imperial patronage in providing for the institutional and material maintenance of Sufi life, but also the inextricable sense in which Sufis were tied to specific political forces. These ties were not merely of financial patronage. More important was a sense of roots and belonging, a cultural and spiritual identity that seemed to tie the Chishtiyya to North India, and Delhi in particular. ${ }^{194}$ The literary connections of the Awrangabad Sufis with the king's men was therefore not only a matter of an association to be revealed or concealed within the narratives of the texts according to the sensibilities of their authors. It was also clearly a consequence of the political and economic foundations that supported the textual ecumene of which the writings of Kāmgār Khān and Shāh Mahmūd were a part. In these ways, the origins and destiny of the Awrangabad Sufis were tied to a Mughal political geography, to cities that were intertwined with an early saintly geography and which possessed the resources capable of lending patronage to living Sufis who chose to migrate to them. 
Yet as well as reflecting a larger picture of imperial history, in the same way that they reveal their associations with the Mughal ecumene the texts also reveal to us a microhistoric perspective that is the reverse of the same coin. For no less than the wider body of literature produced in Awrangabad, the writings of the city's Sufis comprised an essentially migrant literature. From this microhistoric perspective, the Sufi texts show us much about the phenomenon of displacement and the strategies by which it leads to attempts to establish new senses of belonging. For the political and saintly geographies of the texts were also private geographies, places that were remembered either directly or vicariously by first and second generation migrants to the Deccan. Sainthood was always deeply entwined with such private notions of regional identity and family heritage, stretching the allegiances of given families to the saintly protectors of their ancestors generations after their migration into new areas. Just as Jahangir and Awrangzeb attempted to send money for repairs to the tomb of their ancestor Timur in Samarqand, at a remove of decades and even generations Awrangabad's literary migrants like Bilgrāmī, Qasūrī and Shāh Mahmūd remembered their own forefathers and the saints of their homelands in their writings. Saints and their shrines acted as the symbolic registers of family, regional and even ethnic affiliation. It was as much through their interdependence with private senses of identity as through overtly spiritual or missionary endeavour that different Sufi traditions could be introduced into new regions. Through the memory of their homelands, migrants carried their saints with them irrevocably and it was partly as the living servitors of such memories that Sufis like Nizām al-dīn and Shāh Musāfir could re-attach their devotees to the distant saints and shrines of their ancestors in Central Asian and Hindustan.

\section{Saintly geographies: local shrines and pilgrimage in the texts}

For all the possibilities of a political reading of the literary world in which Sufi works were composed, the saints nonetheless mapped out influential geographies of their own. For Sufi hagiographies were invariably grounded on a vision of saintly territory that was allotted and punctuated by the presence of the shrines of the saints. But in Awrangabad as elsewhere in India, relatively few hagiographies existed of saints who did not possess a shrine. For from the earliest period of Sufi history, the tombs of the dead saints and the spiritual power accessible beside them were a given fact that was shared between a specifically Sufi piety and the religious life of Muslims in general. The presentation of the earlier Chishtī saints seen through the many references and anecdotes of the different characters in the Absan al-shama'il was almost without exception one which may also be read as a cataloguing of shrine cults contemporary with its composition. One important contextual function of such texts therefore seems to be as saintly charters for maintaining the prestige of a given shrine by demonstrating the wisdom and miracles (karāmāt) of the saint in question. Sufi hagiography was in such ways also a reflection of local geographies of pilgrimage.

This explicit mirroring of saintly texts and shrines should not surprise us, for except as an exemplary model for didactic narratives, a dead saint had a minimal 
social function in the absence of a shrine to identify his resting-place and so render his power (barakat) accessible. Insofar as they operated within living social contexts, Sufi hagiographies therefore had little practical use without a shrine at which the blessing of the saint could be accessed. This sacred legacy could be shared out in a number of ways, whether in terms of a tradition of religious teachings; of the distribution of the saint's barakat; of forming esteemed places of burial; of the appropriation of saintly authority as a means of legitimating other authorities, including royal dynasties; or of landownership in the hands of lineages of sajjäda nashīns. Here we see Sufi hagiographical texts as the literary manifestation of the wider social and cultural roles of the Sufis, with texts reflecting the sacred geographies of saintly shrines.

Yet in the Awrangabad texts, the shrines had two spheres of existence, as literary places that existed in the writings of Shāh Mahmūd and Kāmgār Khān and as physical places that could actually be visited by readers. Subsequently, the location of graves plays an important role in the Awrangabad texts and the tombs of the characters featuring in the texts had their locations explicitly described if they were not already well-known. Probably as a means of supplementing the prestige of the shrine of the Naqshband $\overline{1}$ masters at their takiyya of Panchakkī, in the Malfūzāt-eNaqshbandiyya the location and fame of the graves of Shāh Musāfir's followers were always included in the sections describing each disciple's travels and achievements. This was reflected in many of the narratives of the last days and burials of the Awrangabad Naqshbandī's' followers in the last third of the text. ${ }^{195}$ The graves of such local medieval Sufis as Burhān al-dīn Gharīb and Muntajib al-dīn Zar Bakhsh at Khuldabad also form the settings for many episodes in the Absan al-shamä'il. ${ }^{196}$ Graves, then, were important as both textual and geographical markers, tying land and literature together. Texts and the tales they told ultimately deciphered the land, pointing to its authorized spiritual and political meanings. The alignment of royal and Sufi mausolea in both Delhi and the Deccan throughout the Mughal period was in this sense no matter of mere coincidence, but part of a wider symbolic mapping of land and rightful dominion over it. Burial - the interment of spiritual and political ancestors in a given territory - possessed great symbolic power at the levels of both writing and ritual.

The Awrangabad texts show how the distinction between the living teacher and the dead saint at his shrine was conceived and navigated by Sufis in the past. For while acknowledging the possibility of communication with the dead and at times actively seeking it, the Awrangabad Sufis were often quite aware of the relative merits of dead and living masters. The most important illustration of this overlapping of cults to living and dead Sufi masters is seen in the several accounts in the Awrangabad texts of pilgrimages made by Shāh Musāfir or Nizām al-dīn to the shrines of the earlier saints that made up Awrangabad's surrounding sacred landscape before the construction of their own mausolea within the city. While such pilgrimages were clearly an important dimension of Sufi life, in spite of the descriptions of Nizām al-dīn's own shrine visitations in the Absan al-shama'il, he is presented in the same text as warning his disciples that the counsel of a living shaykh is always preferable to visiting the tomb of a dead one. ${ }^{197}$ We glimpse here an insight into the ways 
prominent Sufis like Nizām al-dīn steered between participation in public rituals expected of them and what they personally understood as worthwhile spiritual endeavour. Nonetheless, such precautionary admonishing aside, the recognition of the specifically mystical uses of shrine visitation was very much a part of Nizām al-dīn's Chishtī heritage as received from his master Kalīm Allāh. Indeed, a description of a graveside meditation (dhikr-e-kashf-e-qubür) capable of revealing the spiritual states of the saint beside whose tomb it is performed was given in Kashkül-e-Kalimmin, one of the spiritual guidebooks written by Kalīm Allāh. ${ }^{198}$ Sufi meetings at the shrines of various saints in Delhi also feature in the letters sent to Nizām al-dīn by his master. ${ }^{199}$

Shāh Palangpōsh and Shāh Musāfir made three pilgrimages to the earlier Chishtī shrines at Khuldabad, while Shāh Musāfir also visited the death anniversary ('urs) of Shāh Nūr Hammāmī (who had only died in 1104/1692) at his newly constructed shrine in Awrangabad. ${ }^{200}$ Nizām al-dīn and his disciples are for their part described in the Absan al-shama'il as present at a number of shrines and their 'urs celebrations, including those of the Chishtī saints of Khuldabad. ${ }^{201}$ Details of Nizām al-dīn's pilgrimages to the Khuldabad shrines, especially that of the prime figure of the Khuldabad malfūzāt tradition Burhān al-dīn Gharīb (d. 738/1337), give evidence of Nizām al-dīn's integration into what was to Awrangabad the most local of all of the many centres of the Chishtiyya. Here we see how saintly and imperial geographies constantly overlapped. As the Sufi literature that flourished around the shrines at Khuldabad testified, the Sufi centre there had itself been founded as a result of the earlier conquest of the Deccan by the Delhi Sultans and the supposed transfer there of the population of Delhi, including its Sufis. Khuldabad's role as both the fountain of Islam in the Deccan and the centre of a North Indian tradition of Muslim saints aligned primarily to Delhi lent it a renewed importance in the Mughal period. Both directly before and after the Mughal invasions, Shah Jahan and Awrangzeb reaffirmed the status and landholdings of the Khuldabad shrines, while in the following decades their amirs patronized new building projects there. Seen against this background, the Sufi texts from Awrangabad show how the Sufis and notables of Mughal Awrangabad worked together to re-vivify this earlier centre of Sufi and royal burial. ${ }^{202}$ If royal and aristocratic elites granted land and money, then Sufi masters from the region's new centre at Awrangabad came to perform rituals of pilgrimage (ziyārat), death anniversaries ('urs) and musical audition (sama $\bar{a}$ ). Like many of the cultural patterns of Mughal Awrangabad, this process continued into the Āsaf Jāh period and eventually also incorporated the literary edification of Khuldabad in the Rawzat al-Awliy $\bar{a}$ of $\bar{A} z a \bar{d}$ Bilgrāmīi (d. 1200/1786) and the Sawānih of Khāksār-e-Sabzawārī (fl. 1188/1774). ${ }^{203}$ Sufis, sultans and the text producers who surrounded them worked together in re-creating Awrangabad's sacred geography at nearby Khuldabad that linked the Deccan's past to that of Hindustan, and so provided a broad channel of historical continuity between the saints and kings of Hindustan and the Deccan.

Architecture and texts were partners in this project of appropriating or re-directing historical and ritual tradition into new hands. The Awrangabad texts were in this way heirs to an earlier Sufi history brought alive through shrine architecture that was experienced in tandem with the narratives presented in hagiographical texts. 
Statehood formed an important narrative backdrop to this textual tradition, with sultans or their representatives regularly appearing in the texts. History, then, was a central concern of the Sufi hagiographical tradition to which the works of Shāh Mahmūd and Kāmgār Khān belonged. And this effectively meant a Muslim history, that is to say a history of Muslim saints, kings and notables. Kingship possessed a strange magic of its own, a mystique that was celebrated through ritual, robing and other more robust symbolic exercises of power (Michel Foucault's descriptions of public executions spring immediately to mind). As such, it was a symbolic power that hagiographers frequently sought to co-opt for the saints they commemorated, often to show the power of the saints as greater than that of kings. But if late Mughal Sufi texts operated within a narrative realm embedded in imperial cultural and political geographies, this did not prevent them from occasionally challenging the authority of kingship. For the Absan al-shamä'il's warnings against converse with kings (subbat al-salātìn), its stories of the pleading of the ruler of Sholapur for Nizām al-dīn to bring rainfall during a drought, and its account of the Sufi Mīr Sayyid Qanawjī’s hauteur towards Shah Jahan contain an implicit political statement of the relative authority of saints and kings. ${ }^{204}$ It was also a vision that was sometimes shared by rulers themselves. Awrangzeb and Nizām al-Mulk were no less assiduous visitors to living and dead Sufis than their royal forbears. For just as Babur visited the tombs of the Chishtī saints of Delhi upon his conquest of the city, Awrangzeb paid no less court to the tombs of the Deccan saints upon his own conquests of Golkonda in $1097 / 1686 .{ }^{205}$ Yet in his imperial pride Awrangzeb could sometimes pontificate in his letters on the real way to live the dervish life. ${ }^{206}$ But here he trod on the territory of the spiritual rulers with whom he shared his realm. And indeed, in his letters to Nizām al-dīn, Kalīm Allāh was critical of what he saw as the emperor's attempts to combine the two realms of authority in cultivating the image of the pious ruler. ${ }^{207}$ For like his Chishtī forbears, Kalīm Allāh remained ever suspicious of those who would unite worldly power (saltanat) and spiritual poverty ( faqr).

Perhaps in recognition of this, sultans and saints possessed distinct spaces in which their authority was recognized. Yet in doing so, they often shared the symbolic and linguistic vocabularies through which their power was expressed by the common use of such terms as king (shāh), dominion (walāyat) and sultan (sultān) to describe their persons and the ritual of the dargāh (royal court, also shrine) to articulate the places of their power. Like political dynasties, saintly dynasties (silsilas) also rose and fell over time. In this respect, the Awrangabad texts bear witness to the realignment of the Deccan into a Delhi-orientated saintly geography that had earlier been established in the era of the southern conquests of the Delhi Sultans during the thirteenth and fourteenth centuries. The texts are silent on the intermediary age of the $\mathrm{Ni}$ 'mat Allāhī saints of the earlier Deccan capital of Bidar and the Qādirī and Chishtī saints of the more recently vanquished Deccan kingdom of Bijapur. But they are alert to the earlier saintly history of the period before the Deccan's independence from the north under the aegis of the independent sultanates of the Bahmani and their regional heirs in the Deccan. Although saintly fortunes might wane no less than those of the royal dynasties that patronized them, royal and saintly destinies did not always 
unfold co-terminously. In some cases, as in those of the Naqshbandī saints of Bukhara and the Chishtī saints of Delhi and Gulbarga whose histories are evoked in the texts from Awrangabad, the longevity of saintly careers often far outlasted royal ones. Although the Mughal rulers of the Deccan shared their geographic origins with the Naqshbandīs in Herat and Central Asia and with the Chishtīs in Delhi, compared to both of these Sufi traditions the Mughals' claims to authority were much more recent. If members of the Naqshbandiyya forever reminded the Mughals of the shared history that had brought them into India together, then the Chishtiyya were no less aware that they had arrived in Hindustan and the Deccan centuries before either of them. ${ }^{208}$ The Awrangabad hagiographers' stories of this earlier past encoded claims to precedence, with the royal and saintly narratives contained in the Absan al-shamä'il reaching into a hoary pre-Mughal past that by the twelfth/eighteenth century had come to look like an age of Indo-Muslim genesis.

\section{The Sufis and their books: reading and writing in the Awrangabad texts}

As far as the finer details of the ethnography of reading practices are concerned, the function of written material in premodern Sufi teaching remains uncertain. Insofar as the Awrangabad texts furnish a picture of day-to-day life and of methods of Sufi pedagogy in the khanaqahs of the city's Sufis, we may turn to their evidence to address this issue. Despite the Malfüzāt-e-Naqshbandiyya's great wealth of circumstantial details of khanaqah life, whether in terms of reading or writing, literary activity of any kind seems to have played only a limited role in Sufi life in the circle of Shāh Musāfir. Such an absence is telling, in that Sufi biographies often have a tendency to exaggerate the learning of the saint in question (even going so far as to invent the titles of books written by the master), and so while positive claims of literary activity should usually be treated with caution, negative evidence may well speak more plainly. While reference to Shāh Musāfir's attending school as a boy and to a period spent as a teacher in Ghūr (in present-day Afghanistan) suggests that he was already literate before adopting the life of the dervish, the lengthy description of his long apprenticeship under Shāh Palangpōsh reveals a systematic programme of extreme self-abnegation reached through servitude and beggarly destitution, but which contains no reference to any kind of book-learning. ${ }^{209}$ Shāh Musāfir's own methods of instruction do appear to have included a literary element, but this use of texts was circumscribed and clearly introduced into the Sufi curriculum within a specific context of oral tuition. The oral context within which texts were read is quite clear, in that the texts were woven into ex tempore commentaries and discussions that placed authority with the living master guiding the reading, rather than with an independent reader and the author of the text itself. At one point in the Malfüzāt-e-Naqshbandiyya a shared recitation of the Mathnawī of Rūmī leads one dervish to fall into a state of ecstasy $(h \bar{a} l)$, and there are also many other references to group reading sessions in the Absan al-shamä'il. ${ }^{210}$ 
The Awrangabad texts thus reflected and reiterated traditional Sufi structures of hierarchy. This may be seen in the ways in which strategies of writing and reading are reflected in the texts. In the case of Shāh Musāfir, the honour of writing his biography fell to Shāh Mahmūd, who was not only the memorialist of the saint but as his successor was also the inheritor of his saintly authority and property at the takiyya. The strategies through which texts were in turn read at the shrines further reveals this paradigm of structures of authority on the path to knowledge. In the Malfüzāt$e-N a q s h b a n d i y y a$ 's description of a reading group at Panchakkī, we see clearly the workings of a tripartite model of textual reception. ${ }^{211}$ One of the disciples was reading aloud to his co-disciples from a Tadhkirat al-awliy $\bar{a}$ in the presence of Shāh Musāfir, when a dispute broke out over the meaning of a particular section. After some debate among the disciples themselves, it was the master Shāh Musāfir who resolved the situation by providing an authoritative answer to the point in question. Here we see how textual knowledge was communicated via a continuum of authorial voice, private and peer opinion and finally the decisive capping of the master. Such interruptions and $a d$ lib commentaries were often so fulsome as to outweigh the readings themselves, and Kāmgār Khān recalled one such episode in the Absan al-shamā'il involving the reading out of a letter. Clearly frustrated with his co-disciples' many interpolations, he was relieved when Nizām al-dīn came to his aid and warned the others that if such running commentaries were not moderated it would be better not to hear readings at all! $!^{212}$

In such Sufi milieux, textual authority - even an author's control over his own text - was subsumed within a wider schema of the authority of the shaykh. Even within the restraints of these reading groups, texts themselves were by no means all equally accessible and open to unstructured reading. On the contrary, in Sufi circles as in other spheres of learning in Islam, different books and access to them was carefully graded and controlled. In this way, textual knowledge was strictly mediated through the authority of a master who could decide at which point his disciples were ready to read any given text. This practice aimed to control the written word in much the same way that a master decided when and whether to pass on any given teaching through oral means. Here we see the universal Sufi theme of hidden (because dangerous) knowledge. It was the careful protection and limited dissemination of this knowledge that in theory formed one of the fundamental raisons d'etre of the Sufi orders' existence as highly structured communities of knowledge. There is a fine example of this formulation in the Absan al-shamā'il during one of Nizām al-dīn's many discussions of musical sessions (mahfil-e-samāa). Kāmgār Khān was reading from a treatise (risāla) on the subject which recounted how during sama $\bar{a}$ people sometimes 'say the same thing as Hallāj' (i.e. mystically identify themselves with God). To this Nizām al-dīn replied that the same thing had happened to several of his own disciples and that it was acceptable to speak the words of Hallāj so long as it was in the right company. ${ }^{213}$ Here, then, in a classic Sufi formulation, it is claimed that knowledge cannot be expressed openly, but only in suitable company and under circumstances of the loss of self-control. Significantly, in both cases of their mention in the episode described, Hallāj's utterances are glossed as merely 'the words of Hallāj'. 
This perhaps suggests either that the genre of the malfūzat $t$ was not itself considered a suitable text for advanced travellers of the Path or that risks (either in this world or the next) might be run by writing down statements so close to blasphemy. The clearest expression of this form of controlled readerly access is given in the meditational handbook Nizām al-qulūb written by Nizām al-dīn. In the introduction, Nizām aldin warns the idle reader that the book is only suitable for the serious and advanced practitioner of tasawwuf and should, moreover, only be read under the instruction of a living master. This attitude that book-learning was a poor substitute for a living teacher was an axiom of the reading strategies of the Awrangabad Sufis just as it was of their predecessors and contemporaries.

The texts that are mentioned in the Malfizzatt-e-Naqshbandiyya as read by the dervishes were by no means examples of the genre of the technical treatise (risāla) of Sufi theory. Instead, they consisted rather of the literature of Naqshbandī sacred biography, as well as what was already a canon of classical Persian Sufi poetry. While technical Sufi theoretical texts did enjoy success in India, it is by no means clear by whom and in what circumstances these texts were employed. The Malfüzāt-e-Naqshbandiyya suggests that theosophical treatises were by no means the staple of a successful khanaqah. Rather, in the circle of Shāh Musāfir, the Mathnawī of Rūmī and the lyrics of Hāfiz were almost the only non-Khurasani or non-Naqshbandī literary works to receive mention by Shāh Mahmūd. ${ }^{214}$ The general picture of the Panchakkī takiyya provided by the Malfüzāt-e-Naqshbandiyya does not suggest the presence at this time of the significant library that later developed there. ${ }^{215}$ However, we are reminded at several points in the text of the financial value of books, for example when the takiyya's books are hidden during a Maratha raid, and when a form of arrow-spinning divination is employed to learn who had stolen a precious book. ${ }^{216}$ One anecdote has shades of the suggestion that books were regarded as a luxury item not entirely becoming the dervish. After an inventory of the takiyya's possessions reveals the large sum of 500 rupees, two pots of jam and a number of books, Shāh Musāfir is seen to order that everything in his lodge be given away to the poor except the books, which were to be given away to Mīr Muhammad Yūsuf. ${ }^{217}$ In another case, books are used both to manifest Shāh Musāfir's powers and to demonstrate the special sanctity of particular texts when a handler of stolen books finds his entire library turned to dust with the exception of the Mathnawī of Rūmī, the Nafabāt al-uns of Jāmī and the Tadhkirat al-awliyā of 'Attār. ${ }^{218}$

Little is known of the education of Shāh Palangpōsh, who with his 'leopard-skin clad' moniker seems to have shown many of the characteristics of the wandering qalandar. Neither he nor his disciple Shāh Musāfir engaged in literary composition of their own. Such as it was, the literary activity in their circle seems to owe its origins to the education Shāh Musāfir received before he became a dervish rather than to any part of his actual Sufi training. Perhaps in a reflection of the social class of many of the shaykhs' followers, other dervishes resident at their takiyya were literate and due to the learning of Mīr Muhammad Yùsuf some of the orphans resident at the takiyya were also taught to read and write. But these children were destined for a variety of worldly careers rather than being prepared for the spiritual life per se. 
While some of the orphans enrolled in the armies of the Mughals, others joined the upper echelons of the imperial bureaucracy; one of the orphans even went on to become secretary to Nizām al-Mulk. ${ }^{219}$ It would therefore perhaps be incorrect to see their education in reading and writing as part of a specifically Sufi mode of instruction.

In the Absan al-shamā'il, Kāmgār Khān's biography of Nizām al-dīn, the case is rather different. The text suggests that the khanaqah of Nizām al-dīn belonged to a more literary-minded current within Sufism than its Naqshbandī counterpart, for reading and writing seems to have played a central role in the spiritual instruction given by Nizām al-dīn. In addition to Kāmgār Khān's literary efforts, apparently at the saint's command another of his disciples wrote an extensive calendrical guide to the visitation of the shrines of the saints. ${ }^{220}$ Unlike the city's Naqshbandī masters, Nizām al-dīn himself wrote an important manual on the practice of meditation (dhikr) entitled Nizām al-qulūb, while a collection of letters (maktūbāt) sent to Nizām al-dīn in the Deccan from his master Shāh Kalīm Allāh in Delhi is also extant. Shāh Kalīm Allāh was himself an extremely prolific writer in Persian and Arabic of textual summaries of Sufi doctrine and is credited with the authorship of thirty-two other books. $^{221}$

The glimpses of Sufi life revealed in the Absan al-shamä'il seem to reflect an atmosphere in which the use of writing played a wider role than in Shāh Musāfir's circle. There are far more references in the text to reading sessions and other textual activities than in the Malfüzāt-e-Naqshbandiyya. A touching example of such activities describes Nizām al-dīn praising the nast'alīq calligraphy of one of his followers after it had been mocked for its imperfections by his fellow dervishes, before going on to explain the more intricate rules of this difficult script. ${ }^{222}$ Kāmgār Khān's text also reveals a finer sense of the subtleties of literary creation than the Malfüzāt-eNaqshbandiyya, carefully breaking each anecdote into a 'beneficial section' ( $f \bar{a}$ ' $i z a$ ) of its own. Though not original in itself, this practice mirrored the artful construction of the works of Kalīm Allāh. His Kashkūl-e-Katīm $\bar{\imath}$, for example, divided its contents into 94 'morsels' (loqmab), while his Tasnīm al-tawhīd was divided into 20 edifying 'cupfuls' (tasnīm) of knowledge. ${ }^{23}$ Kāmgār Khān also employed the strophe of describing readings from the Kìmiyā-ye-sa' $\bar{a}$ dat of al-Ghazālī as a means of introducing topics for Nizām al-dīn to discuss. The Kìmiyā was a popular work in Indian Sufi circles during this period; a generation earlier the North Indian Naqshbandi Sufi Khwānd Shāh Mu'īn al-dīn (d. 1085/1675) had been inspired by the work to compose his own Kanūz al-sa'a dat, which he dedicated to Awrangzeb. ${ }^{224}$ However, such devices contrast sharply with the literary style of Kāmgār Khān's Naqshbandī contemporary. For despite its enjoyable naïvité, the Malfüzāt-e-Naqshbandiyya is sometimes confused in its organization of material and is stylistically crass by the prose standards of its day.

Like the letters Kalīm Allāh addressed to Nizām al-dīn, the Awrangabad texts possessed specifically pedagogical dimensions that were clearly intended to be instructive and admonishing. While Sufis were always important as teachers, as purveyors of advice if by no means always of metaphysic, they were also important for their 
exemplary actions. Whether quietly moral and pious or dramatically miraculous in nature, word and deed were always seen as interlinked by the Sufis through the emphasis they gave to proper etiquette $(a d a b)$ and practical ethics $(a k b l \bar{a} q)$. It was the ethical and spiritual contiguity of speech and action in the ideal Sufi life that made exemplary tales of the deeds of the saints such a convincing form of Sufi teaching. In the Absan al-shamā'il, Nizām al-dīn's many didactic speeches thus describe the righteous or occasionally miraculous deeds of the earlier Chishtī saints. For in neither Sufi life nor literature were word and event seen as separable.

With this highly specific community of references occupying the text and the circumstances of its authorship, it seems likely that Shāh Mahmūd conceived his readership in terms related to Awrangabad's migrant Central Asian community. Although dying out, the author was at least assured that his own family line could inherit knowledge of the traditions and glory of their forbears along with the property of the shrine itself. Writing with a clear image of the disappearance of the times that he chronicled, it seems unlikely that Shāh Mahmūd expected a wider audience for his memoir than his own successors at the shrine and any future descendants of the city's Central Asian community who should wish to peruse it. A few generations later the shrine had become a kind of architectural memorial to the city's glorious past, associated particularly with the Muslim upper classes of Awrangabad (usually with claims to extra-Indian ancestry). In the same way Shāh Mahmūd seems to have intended his text as a comparable embodiment of memory preserved for the slender future generations of the community that peopled its pages.

The circumstances of the composition of the Absan al-sham $\bar{a}^{\prime} i l$ were rather different. Although we must not project a foreknowledge of the future success of Nizām al-dīn's lineage back into the mind of a writer to whom that success was in some measure owed, there is no sense of loss or nostalgia in the Absan al-shamä'il comparable with that of its Naqshbandī contemporary. Yet the spirit of commemoration was nonetheless at hand and the Absan al-shama'il was no less a work of retrospective memory than the Malfüzāt-e-Naqshbandiyya. The colophon of the Absan al-shamā'il informs us that the text was composed in 1156/1743, a full decade after the death of its subject. This may seem an extraordinarily candid admission in view of the fact that the rhetoric of the text as a malfüzāt collection of 'recorded conversations' required at least the appearance of verbatim transmission. Perhaps this suggests that in an age during which mnemonic recall stood at the base of intellectual life such a claim seemed less inconceivable or that premodern readers took the genre less at face value than modern scholars. Either way, while the date suggests commemoration of the dead Sufi as the broad spur to literary composition, the ten years that had passed between the subject's death and the writing of the text suggest that for many years at least little sense of urgency was felt in the project.

The colophon also explains that the Absan al-shamā'il was composed by Kāmgār Khān at the request ( hasb al-irshād) of Nizām al-dīn's son, Fakhr al-dīn. This is of great significance since the writing of the text took place at a time that was a crucial juncture in the history of Nizām al-dīn's tradition. The text was not only conceived as a memorial to the teachings of a beloved master. For it seems likely that Fakhr 
al-dīn felt that such a document - written by someone other than himself - could prove to be of the utmost importance in enabling him to establish his own Sufi reputation. With such literary proof of the status of his father and master, Fakhr al-dinn could claim to possess an important saintly lineage in his own right, helping him to advance his own career as a professional Sufi. Through the sheer act of literary commemoration, the father posthumously later helped to establish the name of his son in Delhi. It was quite possibly this context of the text's composition that encouraged the text's writer Kāmgār Khān to try to present Nizām al-dīn as himself an heir to and pillar of the tradition of Chishtī saints in Delhi, where Fakhr al-dīn would venture a few years later. This suggests that the Absan al-shamáa'il was written at least partly to secure Fakhr al-dīn's position as a Sufi master with a lineage of repute. And here again we see a textual yoke connecting the Awrangabad Sufis with the older saintly geography of Delhi. For a few years later Mawlānā Fakhr al-dīn established his own Sufi circle in Fīrōz Jang's madrasa in Delhi, presumably helped by the prestige of possessing a malfüzāt honoring his own father.

The intentions of the text seem more sharply directed than those of the Malfīzatt$e-N a q s h b a n d i y y a$, which sought to compress the image of an entire client community around its saintly axis. The ambitions of Kāmgār Khān and his literary director, Fakhr al-dīn, seem to have been at once more limited and more ambitious. It seems symptomatic of its intended audience of a closed and specifically Sufi readership that in classic malfüzät fashion the text was largely set within the enclosed territory of Nizām al-dīn's khanaqah. There could perhaps be no better literary aid to the establishment of a circle of Sufi followers for Fakhr al-dinn than a text describing the discourses of his own father. There seems to be such a mirroring of contents and intended readership in the internal geography of both texts. In reflection of the very kinds of people whom it posited as its likely readers or listeners - certainly Central Asians but by no means exclusively dervishes - the Malfüzāt-e-Naqshbandiyya included the whole gamut of the Central Asians of Awrangabad within its pages, from military grandees to widows and horse-dealers. In a corresponding manner, the ignoring of the wider life and geography of the city in the Absan al-shama'sil to concentrate solely on the circle of formal disciples (murīds) surrounding Nizām al-dīn suggests a similarly exclusive readership. This imagined readership seems to have consisted principally of Chishtī practitioners of tasawwuf, whether situated at the shrine of Nizām al-dīn in Awrangabad or around his son Fakhr al-dīn in Delhi. This pointedly Chishtī specification may be seen in the text's citing of itself within a wider tradition of Chishtī literary works by the rhetorical device of the mention of these earlier Chishtī texts within the texts as being read out by devotees in the presence of Nizām al-dīn. In this way, the Absan al-shama'il could symbolically place itself within a Chishtī canon of earlier classic hagiographies (including those it cites) and at the same time place its subject, Nizām al-dīn, within the canon of the earlier Chishtī saints described in these hagiographies. In contrast to Shāh Mahmūd's emphasis on and reaching towards an audience familiar with the different social roles of Sufis within wider community life, Kāmgār Khān created a work about Sufis discussing Sufism intended in turn for an audience of other Sufis. But unlike the 
posited local readership in Awrangabad envisaged for the Malfüzāt-e-Naqshbandiyya, the Absan al-shama'il's audience spread northwards beyond the local limits of the Awrangabad to Delhi and ultimately to the continuation there of Nizām al-dīn's lineage by his son Fakhr al-dīn. In contrast to the manuscript of the Malfüzāt-eNaqsbbandiyya, which so far as we know was never copied outside of the shrine of Shāh Musāfir, several manuscript copies of the Absan al-shamä'il were later made in different regions of India, from Haydarabad to the towns of western Punjab. 


\title{
THE POETRY AND POLITICS OF SAINTHOOD IN A MUGHAL SUCCESSOR STATE
}

\begin{abstract}
On the day of his death anniversary ('urs) so many lamps and lanterns are lit that the reflection of the pool's water amazes the onlookers and ... the whole city - from the learned to the people of the bazaar and the craftsmen - all are present. ${ }^{1}$
\end{abstract}

\section{Sufi foundations for a new royal city}

Writing in Awrangabad, the great eighteenth-century anthologist and litterateur $\bar{A} z \bar{d}$ Bilgrāmī (d. 1200/1786) composed a treatise in Arabic, Subhat al-marjān, that envisaged India as a sacred Islamic land, beginning with its hosting of Adam's fall to earth in Ceylon after his expulsion from Eden. ${ }^{2}$ Bilgrāmīss purpose formed part of a much wider project incumbent upon the Muslims of India to establish the Islamic credentials of their Indian homeland by maintaining a historical tradition that connected Muslims, their prophets and their saints to India from time immemorial. This process of the localization of Islam took various forms, of which literary works were only one. No less important than such literary works as Subbat al-marjān or the Dakhani Urdu mathnaw $\bar{\imath}$ poems sponsored in the Deccan prior to the Mughal conquests was the patronage of Muslim public architecture. ${ }^{3}$ For through the use of stone, brick and mortar it was possible to modify rural and urban topography so as to plant Muslim roots in the landscape. By the time of the Mughal conquests there already existed a centuries long tradition of Muslim architecture in the Deccan, its grandest edifices lodging the names of the region's Muslim saints and kings in the cultural memory of its inhabitants. But while the Mughal conquest of the independent Muslim sultanates of the Deccan was in no sense a conquest of one religion over another, it was a conquest nonetheless and as such heralded a period of colonization that was Mughal and North Indian as much as Muslim.

This era of Mughal colonization formed the inheritance of the founder of the state of Haydarabad, Nizām al-Mulk Āsaf Jāh (d. 1161/1748). Nizām al-Mulk was the son of the great Mughal general (and companion of Shāh Palangpōsh) Fīrōz Jang, and was also associated with Nizām al-dīn and Shāh Musāfir in his own right. Having started his career in his father's footsteps as a Central Asian officer in Mughal service, Nizām al-Mulk gradually rose to become one of the most prominent figures in the politics 
of both Hindustan and the Deccan. He played a key role in the history of Delhi during the confused years that followed the death of Awrangzeb in 1118/1707, when fractures in the Mughal body politic saw one of Awrangzeb's sons ruling in Hindustan and another in the Deccan. But on his re-appointment as governor (sübedār) of the Deccan after his sojourn in Delhi, Nizām al-Mulk gradually laid the foundations of the Deccan's independence from Delhi under the rule of his Āsaf Jāh successors. During this period, when Awrangabad continued to serve as the capital of the Deccan, the khanaqahs of the city's Mughal Sufis received extensive patronage to transform them into not only the gilded residences of the city's preeminent Sufis but also into centres of local pilgrimage. While the Mughal colonization of the Deccan had thus initiated a programme of architectural patronage in Awrangabad, this was in turn continued by Nizām al-Mulk as a means of expressing his inheritance of the mantle of Mughal authority. He achieved this by using Awrangabad as the capital of his new state after his assumption of control over the Deccan in 1137/1724. Here the fortunes of Awrangabad echoed those of the centres of the other Mughal successor states emerging at this time in such regions as Awadh and Arkat. ${ }^{4}$ While the patronage of such secular architectural forms as markets or fortresses certainly formed part of this process of state formation, the patronage of Sufi shrines was also a key feature of the urbanization projects of the eighteenthcentury successor states.

From the time of its re-foundation in 1092/1681, Awrangabad had found itself placed amid an older sacred Muslim geography, aspects of which the Deccan's Mughal colonists and their Āsaf Jāh successors saw fit to continue patronizing. For like its Mughal sponsors, Awrangabad formed a new urban presence in the Deccan, surrounded by a landscape semantically rich in the evidence of an earlier history of Muslim saints and kings in the forms of royal fortresses and saintly tombs. Just as the Mughal period would later itself bedazzle generations of Awrangabad's subsequent inhabitants, the shrines of the earlier Chishtī saints at nearby Khuldabad and further south at Gulbarga were held in great reverence by the Sufis and princes of Mughal Awrangabad. Yet amid the victorious cityscape of Awrangabad's imperial palaces and gateways, mosques and royal markets, one element was lacking if the new city should outdo its older urban rivals in the Deccan. This was a set of shrines belonging to an exemplary circle of patron saints. ${ }^{5}$ While Awrangabad was the urban paragon of the age, set amid an older Deccan landscape it lacked a history and saintly tradition of its own. For unlike older Mughal cities like Delhi or Lahore, or even the conquered capitals of the Deccan kingdoms at Bijapur or Golkonda, Mughal Awrangabad possessed no important saintly shrines within its walls but only those some fifteen miles away at Khuldabad. When Awrangzeb died at nearby Ahmadnagar in 1118/1707, it was therefore to the Chishtī shrines of Awrangabad's vicarious sacred geography at Khuldabad that his body was taken for burial. For during the Mughal and early Āsaf Jāh periods, Khuldabad's status increased as the Deccan's new rulers sought to connect themselves to the earlier history of North Indian saints and kings that the town and its shrines represented. As a consequence, Shah Jahan, Awrangzeb and the early $\bar{A}$ saf Jāh rulers were keen patrons of the shrines of the Chishtī saints at Khuldabad, 
which were considerably modified with new mosques, gateways and tomb enclosures during this period. It was in competition with this earlier and better-established sacred geography that the shrines of Awrangabad had to emerge.

In the decades that followed Awrangzeb's death, Awrangabad continued for a further half-century to be the most important city in the Deccan. And as Nizām al-Mulk gradually laid the basis for independent rule in the Deccan from 1137/1724, for some four decades Awrangabad acted as the capital of the nascent state of the Āsaf Jāh Nizams of the Deccan. It was during the last years of Mughal rule in the city and the first decades of its inheritance by Nizām al-Mulk from the early 1720s onwards that the Sufi shrines of Awrangabad took their present form. Initially endowed with markets, mosques and palaces during the early decades of the reign of Awrangzeb, under Nizām al-Mulk Awrangabad's architectural patronage once again flourished as the city assumed the role of centre of a new state. Heir to its Mughal founders, Awrangabad continued to act as the major regional political and cultural centre in the Deccan for much of the eighteenth century.

By the time of the death of Nizām al-Mulk in 1161/1748, Awrangabad was therefore well established as the centre of the successor state that would eventually be named after its subsequent capital of Haydarabad. While Nizām al-Mulk and his successors continued to acknowledge the suzerainty of the Mughal emperors in Delhi, and would continue to issue coins in their names until the exile of the last Mughal emperor in 1274/1858, their effective independence was ratified through their status as provincial governors (sübedār) of the Deccan. Nonetheless, the death of the strong man who had carved out the state led to a short but tempestuous period of political chaos as his four sons competed with one another and with outside powers for the control of Nizām al-Mulk's territories. The turbulent reigns of Nāsir Jang, Muzaffar Jang and Salābat Jang, the first three sons of Nizām al-Mulk to inherit their father's state, lasted a total of thirteen years, until the death of Salābat Jang in 1174/1761. During this period, Awrangabad retained its role as Āsaf Jāh capital and as a result stood at the centre of the political manoeuvrings through which the different regional powers competed with Nizām al-Mulk's successors to carve up the legacy of the earlier Mughal conquests in the Deccan. Taking shape around Awrangabad were the forces which would dominate India's political history for the next two centuries, from the renascent Hindu kingdoms of the Marathas based at Poona, Indore and Gwalior to the newer armies of the French and the British, and the rivalry between the Āsaf Jāhs and the rulers of such other Muslim successor states as Maysur (Mysore) and Kurnul (Kurnool).

The events that unfolded in the immediate aftermath of Nizām al-Mulk's death were exacerbated by French and British intrigue, with the rising European powers supporting either side in the civil war that ensued between Nāsir Jang and his brother Muzaffar Jang. Although Nāsir Jang successfully established himself in the struggle against Muzaffar Jang, he was killed shortly afterwards in an encounter with the Pathan rulers of Kurnul. When the news reached Awrangabad there was great panic, which the forces of the Maratha Pēshwā Bālājī used as an opportunity to invade the city. Nonetheless, the military and administrative system installed in 
Awrangabad under Awrangzeb and maintained under Nizām al-Mulk was still effectively intact and the raiders were eventually fought and ultimately bought off. As a result of Nāsir Jang's death, Muzaffar Jang gained control of the Deccan, initiating a decade of increased French influence in the politics of Awrangabad. Stationed in Awrangabad, the French agent Bussy triggered a series of events which would end in the downfall or assassination of several of the major political and cultural figures of the day, including the great statesman and prosopographer Shāh Nawāz Khān (d. 1171/1758). However, Muzaffar Jang's own murder followed the next year and Salābat Jang succeeded him. Salābat Jang was soon recognized as the legitimate successor by the Mughal emperor in Delhi and his ten-year reign brought a degree of normality back to Awrangabad.

During these years India's political landscape was changing rapidly. The British were transforming themselves from one of the many foreign trading communities who had benefited from the commercial wealth and political stability of Mughal rule into a military power that might realistically challenge the other parties vying to claim the former dominions of the Mughals. In northern India the sharpest signals of the end of the old order were the British defeat of the forces of the Nawwābs of Bengal at Plassey in 1170/1757 and the Afghan defeat of the French-aided Marathas at Panipat in 1174/1761 that led to the Afghan ruler Ahmad Shāh Abdālīs occupation of Delhi. Amid the political manoeuvring that followed, in 1175/1761 Salābat Jang was deposed by his brother Nizām 'Alī Khān (r. 1175/1761-1218/1803), the second ruler to bear the title of $\bar{A}$ saf Jāh. Banished to the provincial obscurity of Bidar, Salābat Jang remained there until his death and burial there in 1177/1763 in the Sufi shrine of Multān̄i Bādshāh.

Ultimately, Awrangabad's position would be undermined by the changing political geography of the eighteenth century, which would leave the city exposed on the very borderlands of Āsaf Jāh and Maratha territory. Awrangabad was abandoned by the Āsaf Jāh court in 1178/1763, which turned, in a symbolic statement of independence from the north, to the old capital of the Qutb Shāh rulers in Haydarabad at the heart of the Āsaf Jāh domains. The new capital of Haydarabad would lend the $\bar{A}$ saf Jāh state the name with which it would be forever associated thereafter. But despite the clouds of battle which hung across Awrangabad's horizon during much of the eighteenth century, many aspects of life in the city continued as before. While commerce was reduced, the city nonetheless maintained its famous markets and in terms of cultural life the literary circles established in Awrangabad during the Mughal period continued to produce poetic and commemorative works right until the end of the eighteenth century when Haydarabad proved too great a temptation for all literary aspirants. Yet the middle years of the eighteenth century saw Awrangabad flourish, with its shrines beautified in physical as well as literary terms.

\section{Sufis in the changing cultural landscape of the Deccan}

In order to understand the heritage to which Awrangabad was an heir and the background, both physical and discursive, against which it had to carve out its own 
claims of prestige and sanctity, it is necessary to briefly step back into the centuries preceding the city's foundation. For Awrangabad resided in close geographical proximity to the sites associated with the 'original' arrival of Islam in the Deccan four centuries earlier. This earlier genesis of Muslim history in the Deccan was associated with the invasion of the Deccan by the Sultans of Delhi in 695/1296 and the later transfer of their capital from Delhi to the fortress city of Dawlatabad, hard by the future Awrangabad. In view of the religious dimensions of the Mughal conquests of the Shi' $i$ Deccan states, the symbolism of this geographical association may have been a factor in Awrangzeb's choice of the site to found his new city. For like the earlier northern conquerors, Awrangzeb was also (re-)introducing Sunni Islam to the political realm of the Deccan and may have seen himself as an heir to the Deccan's earlier conquerors from Delhi.

In the wake of this earlier invasion from the north country of Hindustan there followed the relocation of a tradition of Chishtī Sufism that was originally centred around Nizām al-dīn Awliyā (d. 725/1325) in Delhi. This circle was transplanted to the hilltop town of Khuldabad which soon developed into an important Sufi centre, lying only a few kilometres away from Dawlatabad and some twenty-five kilometres from the later city of Awrangabad. As we have seen, this process of the migration of holy men alongside royal conquest was later repeated in Mughal Awrangabad. But despite the short period of the concentration of political authority at Dawlatabad under the Khilji sultanate and the flourishing of the analagous hilltop citadel of the spiritual conquerors at Khuldabad, the geography of both spiritual and political power soon fragmented hand in hand into a number of different centres under the development of the independent Deccan kingdoms between the fifteenth and seventeenth centuries. Sufi groups followed the movements of political power in the Deccan to its new centres, including Gulbarga, Bidar, Bijapur and Golkonda, and in time new shrine centres emerged elsewhere to rival Khuldabad. In the following centuries, a plethora of competing shrines rose and fell across the Deccan, writing and re-writing an entangled map of the sacred over the region's changing political landscape.

During the centuries between this early incursion of the Delhi Sultanate and the later Mughal invasions, a specifically Deccani Muslim culture developed, centred on several political and cultural centres each with its own traditions of Sufi (and in some cases Shi'i) sacred geography. This composite culture itself developed through the input of earlier invasions and the subsequent immigration to the cosmopolitan courts of the Deccan. Mingled with the local environment, these irregular inputs of people, products and thoughts from abroad came to produce a culture that was both deeply cosmopolitan and at the same time rooted in the soil of the Deccan. Migrant Sufi holy men from other regions of the Islamic world played an important part in this culture through the creation of shrines as centres for popular and elite religiosity. A saintly geography of regional Sufi shrines thus developed to complement a topography of Muslim kingship comprising fortresses, palaces and royal mausolea.

The sacred landscape that Mughal and early Āsaf Jāh Awrangabad inherited was not one that had reached it without competition. For while the Chishtī shrines at 
Khuldabad developed and later maintained their success through their association with the coming of Islam to the Deccan in the late thirteenth century with 'Alä' al-dīn Khiljī, the great Chishtī shrine of Gēsū Darāz (d. 825/1422) at Gulbarga engaged in dignified competition early on in its life with the slightly earlier shrine of Sirāj Junaydī in the same city before ultimately emerging victorious as the premier Muslim shrine of the Deccan as a whole. Shifts in political geography could have a decisive influence on the continued recognition of the sanctity and power of a Sufi shrine, as seen in Bidar, which declined as a Sufi centre along with its Bahmani rulers. The importing of holy men played an essential role in the creation of Muslim communities both in areas altogether new to Islam and, as in the case of Awrangabad, in new urban settlements in regions possessing older (if sometimes minority) Muslim communities. ${ }^{6}$ We have already seen the influx of Sufis to Awrangabad during the reign of Awrangzeb, while in his Khazāna-ye-'ämira Bilgrāmī described how Sufis continued to arrive in the Deccan during the reign of Nizām al-Mulk from Central Asia, Iran and the Arab countries as well as from elsewhere in India. ${ }^{7}$ Although Sufis were by no means the only category of holy men in this process - for the presence of descendants of the Prophet (sayyids) and holy warriors ( $g h \bar{a} z \bar{\imath} s$ ) could serve similar functions - they had become its most important participants since around the twelfth century and so Nizām al-Mulk's concern for the presence of such figures in his realm had numerous precedents. As embodied sources of divine power and blessing, sites of power developed around the corporeal presence of such figures both in life and death, over time leading to the creation of a specialized architecture of sainthood. Khanaqahs expressed the sacredness of living Sufi masters, while the grand ritualized mausolea constructed in the same khanaqah complexes fulfilled the same function after their deaths. Often the space for the living and the dead saint was combined, as in Awrangabad, into a single architectural complex.

The origins and early development of the Awrangabad shrines lay in the background of courtly patronage and corporate discipleship that formed a feature of the careers of each of the living Sufis. In the case of each of their shrines in Awrangabad, the construction of a saintly mausoleum was envisaged as part of a wider architectural project that also involved the construction of a mosque and khanaqah. Such mausolea had a long history as the ritual and architectural centres of Sufi khanaqahs throughout the Islamic world, and shrine and khanaqah were twin features of wider Sufi institutions rather than representatives of different kinds or 'stages' of Sufism. While the granting of splendid buildings and remunerative land grants could change the khanaqah from a profitless to a highly profitable enterprise and in so doing bring certain wings of Sufi activity into the folds of state bureaucracy and administration, this did not necessarily alter the forms of religious activity that were conducted there. ${ }^{8}$ As we have seen in Mughal Awrangabad, Sufi interaction with the state and its representatives did not begin either at a specific point in Sufi history nor at a specific point during the transition between the cult of the living and the dead saint, but was rather a perpetual theme of Sufi careers without the grave as much as within it.

With an income provided by land grants, the shrines were able to support khanaqahs and sajjäda nashīn lineages descended from the deputies of the Mughal Sufis 
to continue local traditions of Sufi initiation and practice for several generations after the deaths of their founders. These grants enabled Sufism to maintain itself with a considerable degree of independence. Yet in a premodern society such independence was limited and ties of a political and social kind were inevitable results of the khanaqah system, whether in the eighteenth-century Deccan or in Khurasan and Egypt several centuries earlier. ${ }^{9}$ The foundation of khanaqahs by the wealthy, like the similar aristocratic establishment of monasteries in Europe, therefore had certain provisos attached to it. These might include the right to burial near the blessed grave of the saint (a right assumed by several of the patrons of the Awrangabad Sufis) or the attendance of Sufis alongside their patrons at public gatherings (as with the presence of Shāh Musāfir at the wedding of Nizām al-Mulk). ${ }^{10}$ Aside from personal religious fulfilment, patrons also won prestige and the assurance of the continued remembrance of their name and piety through the entwining of their own names with the more durable memory of the saint. Political partisanship was also inherent in this reliance of khanaqahs on aristocratic patronage and this may have resulted in the determination of certain groups of Sufis to wander rather than settle down in khanaqahs. But like the number of men at arms a prince or notable could summon, the number of Sufis resident and at their godly work within a given town or region represented a form of supernatural insurance that was conceived as one of the crucial public assets of any premodern Muslim state.

Far from robbing khanaqahs of an earlier innocence, such patronage was a feature of Sufism from the period of the khanaqah's early evolution in Egypt and Iran. ${ }^{11}$ Land grants and other endowments (awqāf) attached to shrines were the means by which Sufis no less than 'ulamā were able to maintain themselves over extended periods of time. Like any other mode of knowledge, Sufism required a material base for its continued existence. This continuity was achieved through the maintenance of traditions of sajjäda nashins after the death of a shrine's Sufi founder, lineages which played important roles construed in specifically Sufi forms in the religious life of their communities. For underlying the shrines' functions as dervish hospices and centres for the distribution of saintly power or barakat was their role as centres for the residence and remuneration of the professional class of shrine-managers, impresarios and religious teachers known as sajjäda nashīns. These sajjäda nashīns also played an important part in the transformation of a living Sufi to a posthumous saint. As heir to the spiritual power and authority of his Sufi forbears, the sajjāda nashīn inherited the often considerable material legacy of his predecessors. Subsequently, one of the central functions of his office was as overseer and keeper of the shrine of his predecessor. More than the spiritualized landed gentry they have at times been painted, sajjäda nashins were an integral part of Sufism as an ongoing social institution capable of transmitting itself through time. This is not to deny the wealth of many sajjäda nashins but rather to contextualize it, for as has been shown with regard to Central Asian shrines, the possession of vast landholdings and wealth was often considered a sign of spiritual blessing rather than a disqualification from it. ${ }^{12}$ In practice, sajjāda nashinns formed the most effective means by which Sufism was able to maintain a network of supporting institutions over long periods of time. Without these inheritors of the 
spiritual and material assets of earlier generations able to maintain tasawwuf during the many thin years of royal or aristocratic disinterest (or worse), Sufism could not have achieved the social and intellectual prominence that it did. The extraordinary prominence of Sufism was due to this perpetuum of reverence for its dead saints and the continuation of their legacy by their professional class of successors or sajjāda nashinns. The shrines' role as the residences of self-perpetuating generations of sajjäda nashinns, able to uphold their institutions as centres of public pilgrimage and private Sufi practice, was thus integral to the maintenance of Sufism at the forefront of public culture. Without such institutional patronage the reverse procedure could also occur, as when in eighteenth-century Awadh the social prominence of Sufis was replaced by the rise of Shi $i$ clerics to the same positions of institutionalized influence and wealth. ${ }^{13}$

In each case, the Awrangabad shrines developed around the resident khanaqahs of the living Sufi masters. The burial of Sufis in their khanaqahs was an early and wellestablished practice in India and beyond. The major early Sufi 'Abd al-Rahmān Sulamī (d. 412/1021) was buried in his khanaqah-home in eleventh-century Khurasan, as in the direct background to the Awrangabad Sufis the master of Nizām al-dīn, Kalīm Allāh, was similarly interred in his khanaqah-home in Delhi’s Khānum Bāzār. For such khanaqahs were also usually the homes of the Sufi master and his family, reflecting the fact of marriage as the general norm among Sufis, despite the exceptions among the Awrangabad Sufis. Spiritual and family inheritance seem to have overlapped in this matter from early on in Sufi history, partly under the influence of Islamic law, and khanaqahs were usually handed down through families like any other property or dwelling. ${ }^{14}$ The crucial factor in this process, however, was the means by which such families would develop into professional practitioners of Sufism, part of a well-established class of full-time Sufis that formed an essential feature of premodern Muslim societies. And as we might expect, while some of these sajjäda nashins were better at their work than others, when their inherited charisma failed there were always new recruits who would come along with a greater vocation, lead men to salvation and in time form their own holy lineages in turn. This process was seen with regard to Shāh Musāfir, who despite chafing at the presence in Awrangabad of one such hereditary Sufi (a descendant of the great Central Asian Naqshbandī, Khwāja Ahrār), was himself to initiate a sajjāda nashīn lineage of professional Sufis that would last until the twentieth century. ${ }^{15}$ Yet the traditional activities of the khanaqah continued under the leadership of the sajjāda nashins, with the grave of the founder Sufi forming an important part of the khanaqah's ritual life. Thus was the grave of Shāh Palangpōsh used as a place of meditation by the shrine's early resident dervishes, in the same way that Shāh Palangpōsh had himself sat in meditation (murāqaba) at the graveside of the earlier Sufi Gēsū Darāz while staying at the latter's shrine in Gulbarga. ${ }^{16}$

\section{Awrangabad's Sufis under the early Āsaf Jäb rulers}

The Sufis continued their activities in Awrangabad throughout this period and, in the case of Shāh Musāfir's Naqshbandī centre known as Panchakkī in particular, the Sufi 
circles established a few decades earlier continued to play a central role in the city's cultural and religious life. In some cases, the continued cultural and political prominence of Awrangabad during the middle of the eighteenth century attracted Sufis to the city from other parts of the Deccan. The transfer of members of the Naqshbandi lineage of Shāh 'Ināyat Allāh (d. 1117/1705) of Balapur in the northern Deccan and of Shāh Ghulām Husayn (d. 1176/1762) from Gujarat is discussed in the following sections and other Sufis also moved to Awrangabad to further their careers. One such Sufi was Ghulām Ahmad Kambal Pōsh (d. 1204/1789), who first moved to Awrangabad under the patronage of Nizām 'Alī Khān Āsaf Jāh after the latter was impressed with the Sufi's charismatic blend of learning and audacity. ${ }^{17}$ In Awrangabad he concentrated on the translation of Arabic works into Persian and the writing of scholarly commentaries (bāshiyya) on earlier religious works. But by now well established, the shrines of the city's Mughal saints were more tenacious than any of the individual Sufis who arrived during this period, none of whom were to become the focus of significant shrines in their own right. Despite the socio-political changes in the city, they were able to maintain and even increase their status throughout the period.

By now established for several decades as part of Awrangabad's urban landscape, the dead Sufis of the Mughal city could finally form a sacred history and territory of Awrangabad's own. The primary sacred tradition of the city continued to be the shrines at Khuldabad. Yet there remained an ambiguity in the status of Khuldabad, for like the royal burials that in part provoked them, the hagiographies of the Khuldabad saints written during this period were due to the presence in Awrangabad of the court of the early Âsaf Jāhs. The fame of Khuldabad, which grew during this period due to the effect of Mughal and Āsaf Jāh royal burials and the literary panegyrics of the saints connected to them, was dependent on the existence of Awrangabad as a political centre. For its part, the fame of the newer saints of Awrangabad also rose during the eighteenth century to a point at which the shrines could begin to compete with their older cousins at Khuldabad. The 1180s/1770s was in this respect an important decade in witnessing the writing by Khāksār-eSabzawārī of his Sawānih, the first text in which the saints of Awrangabad and Khuldabad were to appear side by side, a notable literary claim to comparable status.

As the earliest of the city's Sufis, the shrine of Shāh Nūr had already been established by his patron Diyānat Khān at the beginning of this period, while the considerable architectural legacy of Nizām al-dīn and the city's Naqshbandīs provided centres in which their cults could develop during the decades in question. In the case of each of the three Sufi traditions, lineages of sajjäda nashins emerged to oversee the continuation of their respective forms of Sufi practice (both mystical and pastoral) and of the reverence due to their founding masters. It was no coincidence that in the case of the city's Naqshbandīs (and perhaps also of Nizām al-dīn), their first sajjāda nashīns were also their literary memorialists, Shāh Mahmūd and Kāmgār Khān. Through the combination of the sajjäda nashins' efforts with the continued association of the city's notables with the shrines, sufficient fame was won to secure the reputation of these sites as sources of blessing and grace. But one crucial factor was missing in Awrangabad's fulfilment of the criteria of saintly status and this was the 
unequivocal seal of approval granted by a royal burial capable of competing with the many such burials in Khuldabad. Yet this was never to be, for just as the shrines of Awrangabad were reaching a level of high status at which such an accolade may have been conceivable, the royal court left the city forever in the 1760 s.

\section{Shāb Nūrr}

The shrine of Shāh Nūr flourished throughout the eighteenth century under a line of sajjāda nashīns established by Shāh Nūr's nephew, Shihāb al-dīn. ${ }^{18}$ As at other shrines in the city, it was the saint's first sajjāda nashīn who was in large part responsible for establishing the cult of his predecessor. In the case of Shāh Nūr, Shihāb al-dīn's main role was to oversee the construction of a shrine for his saintly uncle with the help of his patron, Diyānat Khān (d. 1141/1729). Shāh Nawāz Khān (who was eventually buried at the shrine after his assassination in 1171/1758) recorded in his Ma'athir al-umarā that Shihāb al-dīn was originally from Bihar. ${ }^{19}$ He also added that although Shihāb al-dīn had served Shāh Nūr in Awrangabad for many years, he was actually appointed as sajjāda nashīn by the saint's notable devotee, Diyānat Khān. As we also see in the following sections in the case of Nizām al-dīn, here we see how patrons were able to make key decisions in the management of the Sufi institutions they founded by appointing those whom they saw fit to manage the shrines. During his years of managing Shāh Nūr's legacy, Shihāb al-dīn made several additions to the shrine with the support of the family of Diyānat Khān. Shihāb al-dīn seems to have been responsible for overseeing the construction of the large-domed mausoleum of Shāh Nūr, as well as of its neighbouring mosque. ${ }^{20} \mathrm{He}$ also oversaw the management and expansion of the site of Shāh Nür's early residence in the Moti Karanjar quarter of the city, where he had resided prior to the construction of his khanaqah (and later mausoleum and so his shrine) near to the residence of Diyānat Khān.

Shihāb al-dīn seems to have been more of a scholarly Sufi than Shāh Nūr and around him in Moti Karanjar there gathered a number of Muslim scholars, including Awrangabad's $q \bar{a} z \bar{\imath}$, Muhammad Ikrām. ${ }^{21}$ With the help of these associates, Shihāb al-dīn established a mosque and madrasa, along with an accompanying mansion (mabal) and pool, around Shāh Nūr's early residence in Moti Karanjar. Several of the scholarly followers of Shihāb al-dīn were buried around this complex, which served to localize Shāh Nūr's barakat in the heart of the city as well as at his shrine in the city's suburbs. ${ }^{22}$ Shihāb al-dīn also established a madrasa outside the main shrine itself, which was supported through the donations of other notables. Upon his death in 1119/1707, Shihāb al-dīn was buried at the main shrine of Shāh Nūr, adjacent to the domed mausoleum of his saintly uncle.

We know little of Sa'd Allāh, the second sajjāda nashīn of Shāh Nūr, other than that he was succeeded by his second son Qutb al-dīn, who in turn became sajjäda nashīn of Shāh Nūr. Qutb al-dīn was described in the Ma'äthir al-umarā as being acquainted with the traditional (manqūlāt) and rational (ma'lūmāt) sciences and as being of good manners and humble disposition. ${ }^{23}$ His erstwhile contemporary, the litterateur and memorialist of Shāh Nūr, Bahā' al-dīn Hasan 'Urūj (d. c.1230/1814), 
would recall Qutb al-dīn's skills as an orator and the speed with which he had been able to commit the entire Quran to memory. But his commitment to scripture and to traditional Islamic learning ( $\mathrm{ilm}$ ) in no way diminished his ardour for the traditions of the dervishes. 'Urūj thus remarked upon his great conscientiousness with regard to all matters pertaining to the death anniversary ('urs) of Shāh Nūr. Upon his death in 1169/1756, Qutb al-dīn was succeeded by his own son (or younger brother) Ghulām Nūr. Ghulām Nūr had been educated by Qutb al-dīn and continued the learned tradition which had developed under Shihāb al-dīn. He wrote a large number of books, for the most part commentaries (hāshiyya) on classic works of logic by Mīr Zāhid and Mīr Zāhid Mullā Jalāl. ${ }^{24}$ Ghulām Nūr was also well known during his own lifetime as a poet. Some time after his death in 1189/1775, 'Urūj recorded a poetic chronogram that commemorated the date of the scholar's demise:

With a thousand sighs the intellect said:

'He whose whole body was light has gone from the world. ${ }^{25}$

On Ghulām Nūr's death, his nephew Nūr al-dīn was elevated to the position of sajjāda nashīn. Nūr al-dīn was described by his contemporary Sabzawārī as being 'educated in the arts of Sufism (tasawwuf) and spiritual wayfaring (sulük) like a shaykh'. ${ }^{26}$ After his death, Nūr al-dīn was eventually succeeded by his son Anwar al-dīn, whose dates are not recorded. ${ }^{27}$

The writer of the pilgrimage guide to the shrines of the Awrangabad region Khāksār Sabzawārī described the different death anniversaries ('arās) of the shrines of Awrangabad during the mid-eighteenth century. Among them, he painted that of Shāh Nūr as the city's major festival, being attended by the learned classes as well as the merchants and artisans of the city. At the time of Shāh Nūr's 'urs, the shrine was said to be surrounded by a street of stalls 'like the bazaars of Egypt', where all manner of fruits, sweets (shirin $\bar{\imath}$ ), sugared almonds (nuql) and 'all that there is in the world' was sold. ${ }^{28}$ Along with the pilgrimage guide of Sabzawārī, another result of the popularity of the saint was the writing of the biography of Shāh Nūr, Khizān $\bar{u}$ bahār, by the professional tadhkira writer Bāhā' al-dīn Hasan 'Urūj (d. c.1230/1814). In this text, the association of Shāh Nūr with such early patrons as Diyānat Khān was celebrated through the recounting of a number of miraculous favours (karāmāt) which the saint granted them. Shāh Nūr thus summoned visions, dealt with outbreaks of cholera and appeared in dreams in order to solve disputes. ${ }^{29} \mathrm{He}$ also first appeared in this text as the great master of breath control (babs-e-dam) in which guise later oral tradition would also primarily remember him. Reflecting a markedly Indian ascetic inheritance, he was described by 'Urūj as being buried underground for periods of meditational breath control for up to seventy years at a time. ${ }^{30}$

Whatever the connection discussed in Chapter 1 of the living Shāh Nūr with bammāms and their courtly and aristocratic associations, the lingering of the unusual nickname of Hammāmī in other texts of this period indicates that the imagery of the bathhouse had become an important part of Shāh Nūr's identity. ${ }^{31}$ This suggests that Shāh Nūr was seen as a 'bammām saint', an urban embodiment of the association of 
saints with water sources that is known throughout the Islamic world. During the Mughal and Āsaf Jāh period there were numerous hammāms in Awrangabad attached to the city's royal and aristocratic residences, as well as to religious institutions such as the 'red mosque' (lāl masjid). We know that Panchakkī, the shrine of Shāh Musāfir, also owned a neighbouring bathhouse and, whether or not this was also the case with the shrine of Shāh Nūr, Shāh Nawāz Khān's account of the saint certainly suggests some kind of connection between the shrine and a nearby hammām. Such associations of Muslim saints with bathhouses were widespread and saints of the bathhouse were particularly common in Syria, where in Aleppo their tombs were found inside the bammām itself. ${ }^{32}$ The North African Sufi traveller Ibn Maymūn (d. 917/1511) described one bathhouse located beside the tomb of the great Ibn 'Arabī in Damascus. ${ }^{33}$ Sufis were also closely associated with hammāms in Bukhara, where several of the city's major bathhouses were named after local saints, an association sometimes forged through the fact that hammäms were often granted to shrines as part of their initial endowment (waqf). Two bathhouses were thus counted among the endowments of the shrine of the great Central Asian Naqshbandī 'Ubayd Allāh Ahrār, while others were associated with Sufi institutions in Iran. ${ }^{34}$ In the countryside beyond the cities, Muslim saints of the waters were widely associated with sacred springs and wells, and examples are known from almost every region of the Islamic world. In the context of the premodern Muslim city an association with the hammām therefore possessed an important symbolism. Indicative of not only ritual purity and the fertile imagery of water, the association also pointed to one of the few public and (if only at certain times) specifically female spaces of gathering in the premodern Islamic city. Like the imagery of water itself, this sense of public space contained important associations with fertility, for shrine and hammām were the main places in which women were able to exercise influence in the arrangement of marriages. This association of shrines with lovers' meetings was later reflected in a romantic mathnaw $\bar{\imath}$ of the Urdu poet Shawq (d. 1288/1871), in which a Sufi shrine in Lucknow acted as the excuse for a lovers' tryst. Whatever its early origins, by this period Shāh Nūr's name had thus become interfused both with the architectural imagery of the Muslim city and the social customs of his clientele that enlivened it.

In the decades following the transfer of the Āsaf Jāh capital, Shāh Nūr's shrine continued to bask in the stately associations of its early patrons and was able to maintain an association with the administrative and military servitors of the Āsaf Jāh state. These connections with local elites also had material effects and a pair of engraved silver doors to Shāh Nūr's burial chamber were presented to the shrine, possibly by Nizām 'Alī Khān himself. A number of grandiose tomb enclosures in the roofless style popular during the late eighteenth century were also built around this time. This fashion for uncovered tombs followed the examples set by the burial of princess Jahānārā (d. 1092/1681) at the shrine of Nizām al-dīn in Delhi and of her brother Awrangzeb at Khuldabad, and was later continued in Haydarabad by such preeminent aristocratic families as the Pāēgāhs. Several of the tomb enclosures around Shāh Nūr's shrine belonged to the Sālār Jang family, an important Shi i family partly originating in Awrangabad and with a long-established tradition of state 
service. Other tombs seem to have belonged to other prominent local Shi ' $\mathrm{i}$ families of the period. ${ }^{35}$ This association with the city's İrānī community was a continuation of the circle around the living Shāh Nūr himself. Thus arrayed with a party of supporters able to maintain the literary and architectural insignia of sainthood, the second half of the eighteenth century saw the definitive consolidation of the fellowship of the obscure dervish of the Mughal city to the position of Awrangabad's principal saint. Capable of miracles of literally breathtaking power, by this point Shāh Nūr had been transformed into a saint whose posthumous blessing could be sought by all, from men of state to the women of the public bathhouses.

\section{The saints of Panchakkī}

The tradition of Shāh Palangpōsh and Shāh Musāfir also maintained its position of early prominence in the city during the eighteenth century. Shāh Musāfir's successor Shāh Mahmūd oversaw the expansion of the shrine to the degree that it acquired much of the surrounding property along the riverbank beneath the city walls (Figure 2.1). Yet with their own gateway in the city walls, the Panchakkī saints' position as spiritual gatekeepers to the city at large seems to have been regarded more

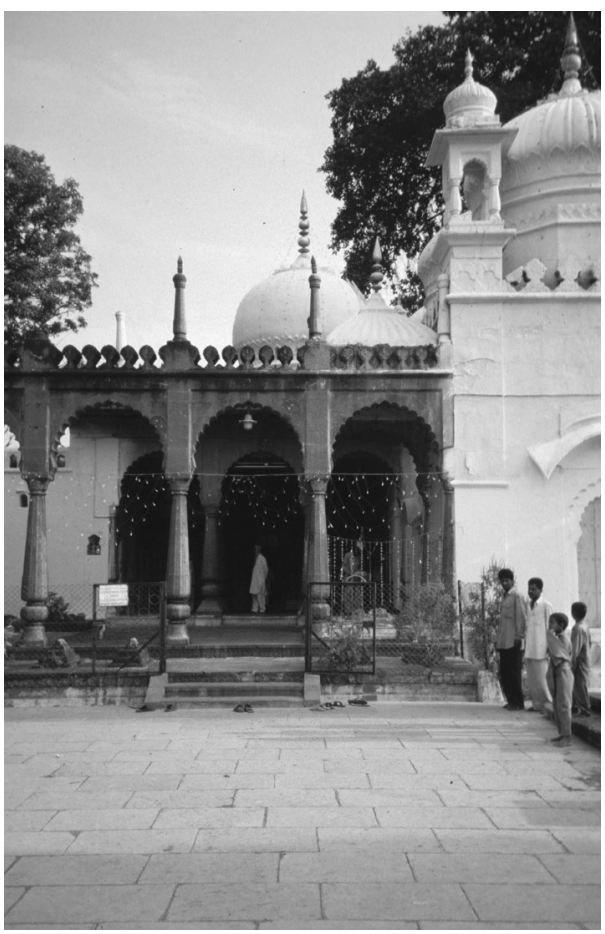

Figure 2.1 Panchakkī, the shrine of Shāh Musāfir and Shāh Palangpōsh. 
as a cause for alarm than peace of mind among the more pragmatic members of Awrangabad's Āsaf Jāh governing class. These concerns came to a head during the series of Maratha raids on the city that took place in the years following the death of Nizām al-Mulk in 1161/1748. For in view of the shrine's adjacent location to the city walls and the relative weakness of the gate built by Shāh Mahmūd, Panchakkī came to be regarded as the weak point in the city's defences. In many ways this was ironic, for around the same time the shrine's sajjäda nashīn Shāh Mahmūd celebrated the miraculous power of Shāh Musāfir to ward off the raids of the Marathas, while the constant threat of Maratha incursions also partly underwrote Shāh Mahmūd's veiled assurances in the Malfūzāt-e-Naqsbbandiyya that the barakat of Shāh Musāfir was capable of defending the city indefinitely. Others, however, did not share his faith and the statesman Dargāh Qulī Khān (d. 1180/1766) took the decision to defend Shāh Mahmūd's gateway by more practical means. For all Dargāh Qulī Khān's literary celebration of the saints and shrines of Delhi a few years earlier in his famous Muraqqa'-e-Diblī, the Khān decided to trust in the force of arms rather than the promise of saintly intercession. Seven hundred soldiers were positioned in readiness to defend Panchakkī and prevent the city's defences from being breached when the Maratha forces of the Pēshwā were expected to attack in 1164/1751. ${ }^{36}$

Like Nizām al-dīn's biographer Kāmgār Khān, Shāh Mahmūd also featured in one of the poetic anthologies compiled for the early Āsaf Jāh rulers. This was the Gul-e$R a^{\prime} n \bar{a}(1182 / 1768)$ of the Hindu bureaucrat and man of letters, Lakshmī Narā' in Shafīq Awrangābādī (d. 1224/1808). Shafīq described Shāh Mahmūd as one of the greatest shaykhs of the Deccan and as serving as sajjäda nashīn at the shrine of Shāh Musāfir for around fifty years. ${ }^{37}$ Claiming that Shāh Mahmūd was followed by all of the great men of the Deccan, Shafīq added that it was he who constructed the pools and conduits at the shrine as well as the bridge leading to it. When Shāh Mahmūd died in $1175 / 1762$, a poetic chronogram was written for him by his friend Āzād Bilgrāmī, who had earlier penned a chronogram for Shāh Musāfir's death. ${ }^{38}$ After Shāh Mahmūd died, he was succeeded by his son, Shāh Muhammad Sa '̄id. ${ }^{39}$ Given the family tradition that Shāh Mahmūd was the nephew of Shāh Musāfir, this would have meant that the shrine now passed into the hands of the saint's great-nephew. In view of the sajjāda nashīns' role as professional mystics, Shāh Mahmūd's successor Shāh Sa'īd was described by Sabzawārī as devoted to the different forms of Sufi meditation (dbikr, murāqaba). ${ }^{40}$ In the mid-1770s, Sabzawārī also reported that the shrine's khanaqah was still the residence of a large number of dervishes as well as local notables (umara $\bar{a}$ ), who would regularly gather to sit in circles repeating the characteristic loud chant (dhikr-e-jahr) of the Naqshbandiyya. ${ }^{41}$ Bilgrāmī, however, hinted that the shrine was not always filled with people of the same level of learning as he and his friends. In his Khazāna-ye-'Āmira, he recalled an occasion on which he went to meet Shāh Mahmūd at a gathering (majlis) beside the shrine's pool and was introduced there to a man with the unusual name of Ba'd Bā'l-dīn. Everyone was surprised to hear this nonsensical name, and all were later amused to realize that the man's parents, who had no understanding of Arabic, had named their son after a series of words in the Quran that had sounded to them like such Arabic names 


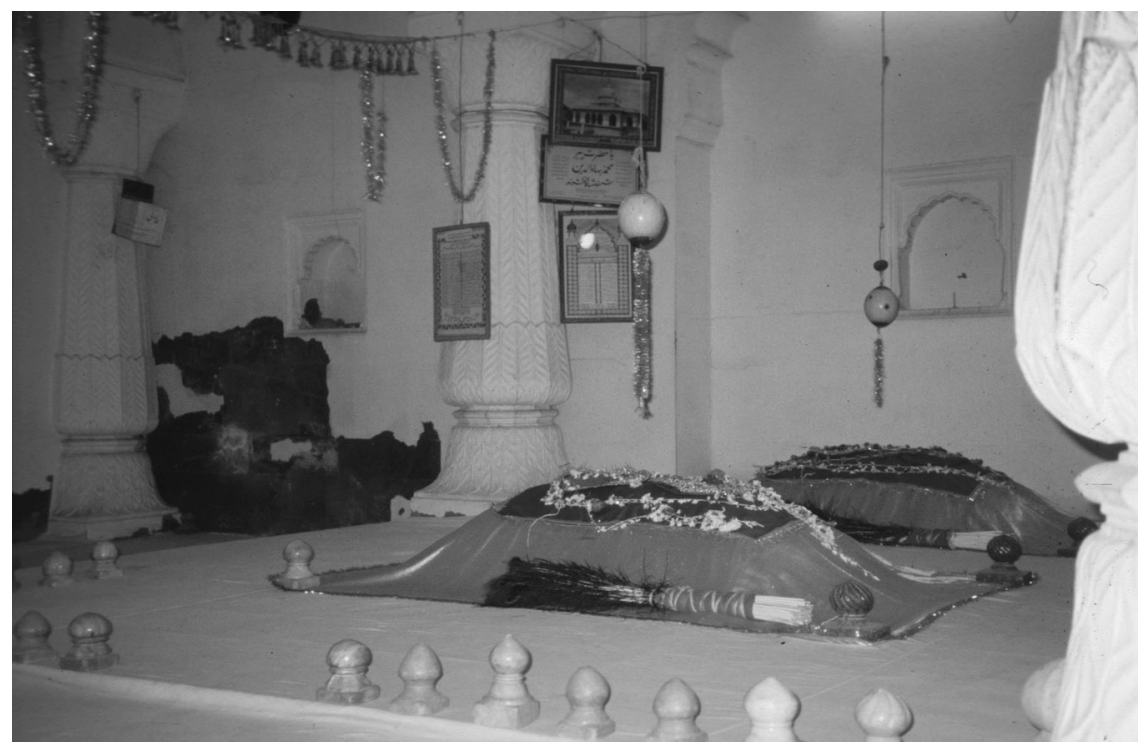

Figure 2.2 The tombs of Shāh Musāfir and Shāh Palangpōsh.

as Fazl al-dīn. ${ }^{42}$ The shrine was also described by Sabzawārī at this time as a centre of pilgrimage for travellers from beyond the city. ${ }^{43}$ Such visits may well have coincided with the celebration of the death anniversary of Shāh Musāfir and Shāh Palangpōsh, which was celebrated throughout this period. A document referring to expenses at the 'urs in 1186/1772 of 678 rupees suggests that the anniversary was celebrated on a lavish scale. ${ }^{44}$ This line of sajjäda nashīns continued through four more successors, all of whom were buried in the forecourt of Shāh Musāfir's mausoleum.

The large number of surviving revenue documents from the shrine show that it continued to amass land grants and revenue donations from public and private sources from the time of its construction through to the late nineteenth century. Bilgrāmī noted in his Khazāna-ye-'Āmira the assiduity with which his friend Shāh Mahmūd was able to acquire grants ( $\left.m a^{\prime} \bar{a} s h\right)$, though he also remarked on the respect the sajjäda nashin commanded by spending all the money that was raised on guests or travellers (wärid $\bar{u} s \bar{a} d i r) .{ }^{45}$ In addition to receiving donations of land, the sajjāda nashinns of Panchakkī seem also to have actively engaged in the purchase of land themselves, as seen in a document dated to $1173 / 1759 .{ }^{46}$ Another important element of the wealth of Panchakki was the series of tax (mahsul) exemptions granted upon revenue from its lands that were confirmed at various points in the eighteenth and nineteenth centuries. Several such exemptions were made on behalf of the government of Nizām 'Alī Khān Āsaf Jāh in 1189/1775. ${ }^{47}$ But Panchakkî̀s income did not only come through its connections with the Āsaf Jāh state and grants were also made by the rulers of the neighbouring Maratha kingdoms. In 1161/1748, the prime minister 
(dīwān) of the Maratha Pēshwā at Poona granted the shrine the right to collect a tax (chawth) from the village of Mokasa in the Pēshwā's dominions, and other grants from Maratha rulers and notables were confirmed in Marathi documents written in the Modi script. ${ }^{48}$ Such Maratha patronage of a Sufi shrine was by no means unique at this time and the shrines of Khuldabad and Burhanpur also continued to be supported in this way. ${ }^{49}$ The support of Panchakkī along with the Khuldabad shrines by the Pēshwā does, however, reflect the status of the shrine during this period. But we must also bear in mind that Awrangabad was close to the border between the territories of the Pēshwā and the Nizāms and was raided and occupied by Maratha forces on several occasions. Patronage of Panchakkī seems, then, to have been part of a wider competition for control of the region, as seen in earlier centuries in the competing for patronage of the Deccan's shrines by the Mughals and the independent sultans of the Deccan. The patronage of the Maratha rulers of Poona must therefore be seen in the same light as the earlier patronage of the Mughals of the Khuldabad shrines in the years before their outright conquest of the region.

Income or 'gifts' (nadhrāna) continued to be granted to Panchakkī from the state or its representatives in more direct ways. In 1204/1789, for example, the Nizām's government granted the shrine the harvest of fruit from several gardens of the Purajāt district of Awrangabad to help cover the expenses of the faqirs. ${ }^{50}$ Wealth and income were subsequently rarely an issue for the shrine during this period, in which its status continued to rise until it became one of the most significant landholders in the Deccan. Unsurprisingly, when in the middle years of the eighteenth century the wellknown writer Āzād Bilgrāmī chose to drop out of society in Awrangabad in $1153 / 1740$ and spend seven years living the life of a dervish, it was at Panchakkī that he chose to reside. ${ }^{51}$ Around him at the shrine there gathered a considerable literary circle, composed of both visitors and permanent residents able to reside, like Bilgrāmī, at the shrine of Shāh Musāfir through the benevolence of its sajjāda nashīns. Many of these figures were of the same Central Asian ancestry as the saints of Panchakkī, as in the case of 'Ārif al-dīn Balkhī (d. 1171/1765). 'Ārif al-dīn travelled from Balkh to the Deccan, where he came into the service of Nizām al-Mulk. Writing under the pen name of 'Ājiz, 'Ârif al-dīn became a member of Bilgrāmī's literary circle and settled at Panchakkī under the years of its management by Shāh Mahmūd. His poetry was much respected by his contemporaries, and Shafīq Awrangābādī recorded numerous verses that he had written. As in the case of the poets Mu'iz al-dawla Jur'at (d. 1175/1762) and Shāhid Mullā Bāqir (d. 1178/1764), many of these residents of the shrine had either been attached to Āsaf Jāh service or were otherwise drawn from the same social background as the master Bilgrāmī himself. ${ }^{53}$ Another resident at the shrine during this period, Mīr Fakhr al-dīn Tirmidhī, was also a poet and Sufi of Central Asian descent and lived at Panchakkī for several years before his burial there in 1190/1776. ${ }^{54}$ Another of Bilgrāmī's literary disciples was Sayyid 'Abd al-Qādir Mihrbān (d. 1204/1789), the custodian of the shrine of Burhān al-dīn Gharīb at Khuldabad. Like Bilgrāmī and other writers of the period, his interests spanned Sufi and more literary matters, and he composed a large poetic dīwān as well as Sufi-inspired works such as his Miftāh al-ma'ārif ('Key to 
the Ways of Knowledge'). Like many other literary and Sufi figures from the region, he later abandoned Awrangabad after the relocation of the Āsaf Jāh court and moved to Madras where he became an intimate of the Wālā Jāh ruler, Muhammad 'Alī Khān.

For most of the eighteenth-century Panchakkī still seems to have retained links with the remaining, albeit much reduced, Central Asian community in the Deccan. Burial played an important part in this, and early in the century great lengths were often gone to to bring the dead to Panchakkī for interment, as for example after the deaths of Shāh Palangpōsh in Gulbarga and Shāh Musāfir's follower Shāh Qalandar at Haydarabad. The site's original association with a Central Asian clientele was still in full flow during the 1770s when Sabzawārī made emphatic reference to the continued presence of immigrant or wilāyat-zāad ('homeland-born') Central Asians among the shrine's resident dervishes, as well as to the Central Asian (türānn $\bar{\imath})$ ethnicity of the sajjāda nashīn himself. ${ }^{55}$ Sabzawārīs subsequent use of the ethnic term Mughal (moghol) in this context is further indication of the high social class of the shrine's residents at the top of the Indo-Muslim social hierarchy of the ashräf. The presence of fine and splendidly woven Central Asian carpets and beautifully decorated dervish cells at this time also point to the shrine's wealth. Sabzawārī twice described Panchakki as the finest takiyya in the whole Deccan. ${ }^{56}$

The rare technology of Panchakkī's eponymous watermill also seems to have contributed to its wealth through the milling of large amounts of grain for sale (probably gathered from the shrine's own landholdings) as well as being used at a fee by small-scale farmers. Sabzawārī recorded proudly that the perpetually turning watermill could grind large amounts of grain every hour, amounts that were clearly in excess of the needs of the shrine's residents and suggestive of a good measure of commercial enterprise. ${ }^{57}$ It is worth noting in this respect that Anatolian Sufi lodges of the same period also brought in a large part of their income as major sellers of grain. ${ }^{58}$ Sabzawārī also described the presence at Panchakkī of a group of weavers, suggesting that under good management shrines could also form the basis for smallscale industrialization. ${ }^{59}$ Although the indigent and orphaned first looked after at the site by the living Shāh Musāfir were still present, ${ }^{60}$ the shrine had become the favoured retreat of the city's elites. An exclusive place to which the well-born could withdraw to meditate and write in the comfort and company to which they were accustomed, the shrine promoted the cult of a saint with only a limited albeit high status following.

\section{Nizām al-dīn}

Compared to Panchakkī, the shrine of Nizām al-dīn was regarded as of lesser importance by the elites of Awrangabad during this period. Its buildings were in any case too small to accommodate the numbers of dervishes and scholars present at the shrine of Shāh Musāfir. But it seems that its status was also diminished by the departure for Delhi of Nizām al-dīn's son and chief spiritual heir, Mawlānā Fakhr al-dīn, in the years before 1163/1750. Nizām al-dīn's legacy in the city in the years after this 
point seem to have been managed by either his local deputies (khaliffas), including perhaps Kāmgār Khān and Shāh Sharīf, who both seem to have managed the shrine in the middle years of the eighteenth century, or by one of his older sons. But there is no doubt that the centre of Nizām al-dīn's spiritual legacy shifted to Delhi with the departure of his younger son, Fakhr al-dinn. Despite the documentation of the circle of Fakhr al-dīn in Delhi during this period, nothing is known of the fate of the tradition of Nizām al-dīn in Awrangabad in the years directly following Fakhr aldīn's departure. It may be assumed, however, that Kāmgār Khān's successors continued to manage the shrine and maintain contact with Fakhr al-dīn and his heirs in Delhi, who would have maintained overall authority over the shrine in Awrangabad.

Nonetheless, the departure of the main line of Nizām al-dīn's charismatic descendants for Delhi left the saint's heritage insecure in Awrangabad. When Sabzawārī described the saints and shrines of Awrangabad in the 1770s, Nizām al-dīn received much less attention than either the saints of Panchakkī or Shāh Nūr. The shrine probably still maintained a limited congregation of devotees due to the well-known association of Nizām al-dīn with Nizām al-Mulk, which itself formed the centrepiece of Sabzawārì's muted account of Nizām al-dīn. ${ }^{61}$ But with the departure of the Āsaf Jāh court for Haydarabad, the shrine seems to have been unable to build a popular following in Awrangabad on the scale of that of Shāh Nūr. Despite the fact that Sabzawārī recorded the death anniversaries of the other saints of Awrangabad and Khuldabad, he failed to mention the date of the death anniversary of Nizām al-dīn, suggesting that it was not a popular event in the city's calendar like those of Shāh Nūr and the saints of Khuldabad. This seems to contradict the statement made around the same time in Delhi by Fakhr al-dīn's hagiographer 'Imād al-Mulk, who claimed that Nizām al-dīn's death anniversary was still celebrated in Awrangabad. ${ }^{62}$ Reading between the two sources, we may assume that it was celebrated but was not as popular a celebration as those of the other saints of the city and of nearby Khuldabad described by Sabzawārī. By the second half of the eighteenth century it was the son in Delhi rather than the father in Awrangabad who lay at the centre of both Sufi and courtly attention. Despite the connections of Nizām al-Mulk with Nizām al-dīn and the fame of his son in Delhi, there is no evidence of either an architectural or a literary kind to indicate that the shrine of Nizām al-dīn was viewed at this time as anything more than one among several other of the city's saints. It would take more than a century for Nizām al-dīn's local preeminence to establish itself through the combined effect of legends associating him with the foundation of Haydarabad State and the legacy of his famous descendants in Delhi.

The denizens of Delhi, renascent during this period, seem to have been capable of wounding the pride of Awrangabad's literary celebrants. Though writing in Awrangabad, in the 1180s/1770s Sabzawārī was fully aware of the circle of important people gathering around Fakhr al-dīn in Delhi, who 'benefit from his words, do not leave his side and serve him with dirhams and dinars'. ${ }^{63}$ It is difficult to be sure of how to read Sabzawārī's comments on Fakhr al-dīn, but there seem to be elements in them of a charge of betrayal for his leaving Awrangabad for Delhi and hints of disapproval of his association there with the rich and famous. The main primary sources 
on Fakhr al-dīn's life are the writings of the descendant of Nizām al-Mulk, 'Imād al-Mulk Fīrōz Jang III (d. 1215/1800). An erstwhile waz̄̄r in late Mughal Delhi responsible for the blinding of one emperor and the assassination of another, 'Imād al-Mulk appropriately (if also a touch ironically) adopted the pen name (takhallus) Nizām ('order') for his own varied poetic enterprises. ${ }^{64}$ 'Imād al-Mulk's various biographical works on Fakhr al-dīn include a malfūzāt entitled Fakhr al-tālibīn, the Manāqib-e-fakhriyya and a long mathnawī poem entitled Fakbriyyat al-nizām. Another important early work in this tradition was the Shajarat al-anwar of Rahīm Bakhsh Fakhrī (fl. 1194/1780). However, continuing the scholarly tradition of his father Nizām al-dīn and his father's master Kalīm Allāh before him, Fakhr al-dīn was an important Sufi scholar in his own right. He composed a large number of works on a range of religious subjects pertaining not only to Sufism but to a variety of other aspects of Islamic religiosity. His books, which looked forward to the collusion of mystical and traditionist scholarship that would reshape Indian Islam over the century after his death, included Nizām al-'aqa' $i d$ and Fakbr al-hasan. For much of his career in Delhi, Fakhr al-dīn taught in the great madrasa that had been founded in Delhi by the ancestor of his and his father's patrons, Ghāzī al-dīn Khān Fīrōz Jang. Although Fakhr al-dīn counted some of the leading figures of Delhi's political scene among his followers and acquaintances, he also taught a number of Sufis who in the twilight years of the Mughal dynasty would go on to found new branches of the Chishtī order right across northern India. One of the most significant of these subbranches developed through Fakhr al-dīn's follower Nūr Muhammad Mahārawī (d. 1205/1790). ${ }^{65}$ In line with such scholarly Naqshbandi Sufis in Delhi in the same period as Shāh Wal̄̄ Allāh (d. 1176/1762) and his son Shāh 'Abd al-Azīz (d. 1239/1824), Nūr Muhammad was keen to clarify and uphold the links that bound the practice of Sufism to the greater vehicle of Muslim piety as delineated in the shari $\bar{c} a$ and exemplified in the custom (sunna) of the Prophet Muhammad.

Upon his death in 1199/1785 at the age of 73 lunar years, Fakhr al-dinn was buried in Delhi at the shrine of the earlier Chishtī saint, Qutb al-dīn Bakhtiyār Kākī (d. 633/1235), whose feats had so often featured in his father's malfüzāt, the Absan al-shamä'il. In death as in life, Fakhr al-dīn was surrounded by the best company in Delhi and the late Mughal emperors Akbar Shah II and Shah 'Alam, along with much of the Muslim aristocracy of Delhi, were interred near him at the same shrine. Many years later, the court diary of the last of the Mughal rulers, Bahadur Shah II, recorded the attendance of the emperor's representative at Fakhr al-dinn's death anniversary in $1268 / 1851 .{ }^{66}$

\section{The literary tradition}

\section{An overview: the literary scene in early Āsaf Jāb Awrangabad}

During its years as Mughal capital under Awrangzeb, Awrangabad developed into an important literary centre. Although Delhi retained its role as a centre of literary patronage and production throughout the reign of Awrangzeb (not least through the 
salon of his sister Jahānārā), Awrangabad played a central role in the period's literary history through the relocation of the Mughal court to the Deccan. Under Nizām al-Mulk and his early successors, this role continued and came to concern not only Persian letters but also the evolution of Urdu (or rekkta, as it was called in this period) as a literary medium. The importance of the Awrangabadi poets Wali (d. 1119/1707) and Sirāj (d. 1177/1766) in the foundation of Urdu literature is well-known. ${ }^{67}$ Of course, Mughal Awrangabad was not only a centre of poetic creativity and was also host to the writers of religious literature, including the writers of such Sufi texts as those discussed in Chapter 1 and the compilers of the great Mughal compendium of legal scholarship, Fatāwā-ye-'Álamgīrī. With the death of Awrangzeb and the gradual reassertion of Delhi's position as centre of the by now diminishing Mughal imperium, Awrangabad was able to maintain its role as a literary centre. Supported by an important paper industry in the small town of Kaghdhipura ('town of paper') on the road between Awrangabad and Khuldabad, Awrangabad's literary scene was one of the most vibrant of the age.

As we have seen with regard to the Sufi and other texts produced by the followers of Shāh Musāfir and Nizām al-dīn during the first two decades of Âsaf Jāh rule, eighteenth century Awrangabad remained embedded in an essentially Mughal cultural and political geography that tied its writers to the cultural life of Delhi. The rise in status of rekkta Urdu was in itself the most obvious example of this, its richness evolving from the meeting in Awrangabad of the vernaculars of Delhi and the Deccan after centuries of largely separate development. Yet like the northerly travel itineraries that we have seen detailed in the Malfüzāt-e-Naqsbbandiyya and the journey of Nizām al-dīn's early biographer Kāmgār Khān to the khanaqah of Kalīm Allāh in Delhi, the changes in the language and literature of the period were the consequence of the mobility of writers and the communities for whom they wrote. Such Sufi travellers as Kāmgār Khān were by no means the only mobile men of letters to journey to and from Awrangabad. The period of Mughal rule had seen the city's biggest influx of soldiers, poets and the other hangers-on of empire, but such journeys continued to be characteristic of its literary life. Illustrating both aspects of this process, perhaps the most famous of such journeys were those of Walī and Dargāh Qulī Khān Sālār Jang (d. 1180/1766). Walī’s decision seven years before the death of Awrangzeb to quit Awrangabad and take his verses to Delhi became one of the key moments in later constructions of Urdu literary history, the mythical moment when the golden age of Urdu literature was first smelted. Like Wal̄ị, Dargāh Qul̄̄ Khān pursued a literary career spanning the cities of Delhi and Awrangabad. His visit to Delhi in the company of Nizām al-Mulk resulted in the composition of his Risāla-ye-Sälār Jang (more famous in its Urdu translation as Muraqqa'-e-Diblī) on the shrines of Delhi and the courtesans and singers whose talents might be enjoyed there. Unlike Walī, however, Dargāh Qul̄̄ Khān was to return to Awrangabad and eventually die there. It remains unclear whether he was buried in the necropolis at Harsul or in the shrine of Shāh Nūr.

Dargāh Qulī Khān was only one of a large number of literary figures who gathered around Nizām al-Mulk and his sons during Awrangabad's years as Āsaf Jāh capital. 
Reflecting the position in the service of Awrangzeb of Bhimsen, the Hindu author of the Persian history Tărīkh-e-Dilkūshāa, this literary circle included such Hindu figures as the father and son bureaucrats and chroniclers Lālā Mansārām (d. after 1175/1761) and Lakshmī Narā'in (d. 1224/1808). Muslim authors in the political service of Nizām al-Mulk included Jur'at Khān Mu'iz al-Dawla (d. 1175/1761), whose works included the epistolary compilation Inshä'-e-jur'at, while Nizām al-Mulk's own letters were later compiled under the title Gulshan-e-'Aja'i $i b$ by another non-Muslim bureaucrat, Munshī Rām Singh. However, by far the most famous of the early literary companions of the Āsaf Jāhs in Western scholarship was Shāh Nawāz Khān (d. 1171/1758), whose account of Shāh Nūr we have already discussed. The biographical dictionary of Mughal notables that he compiled in Awrangabad entitled Ma'äthir al-umarā remains one of the most important sources of Mughal history. Like Dargāh Qulī Khān, Shāh Nawāz Khān was also involved in the political life of the $\bar{A}$ saf Jāh court, a career which would eventually cost him his life during the years in which French intrigue found a home at court in Awrangabad. The political careers of these men of letters (or, alternatively, the literary careers of these politicians) serve to remind us of the myriad connections that tied texts to the social and political concerns of the age.

As Awrangabad's role as regional capital was cemented under Āsaf Jāh rule, there emerged a need to celebrate its cultural, and especially literary, achievements through the production of biographical dictionaries and literary anthologies. Notable poetic anthologies written in Awrangabad during this period include the Tubfat al-shu'arā (1165/1751) of Afzal Bēg Qāqshāl, the Mardum dìda (1175/1761) of 'Abd al-Hakīm Lāhawrī, the Gul-e-Ra'nā (1182/1768) of Shafīq Awrangābād̄̄ Lakshmī Narā' in and the Gul-e-'ajā'ib (1192-3/1778-80) of Asad 'Alī Khān Tamannā. A particular objective of such anthologies was to celebrate the role of Awrangabad in the development of rekkta poetry, which had by this time established itself as more than a passing fashion of poets otherwise devoted to the veneration of Persian letters, though Persian verse retained its supreme position at this time. The capacity to compose poetry was an accomplishment required of any late Mughal gentleman. In this sense, as Awrangabad's Āsaf Jāh anthologists realized, a city's reputation as a poetic centre reflected well on its wider status. Poetic production, both in terms of quality and scale, was a well-established measure of cultural achievement and one which would later be continued by the champions of Delhi, Lucknow and Haydarabad as the major centres of Urdu letters.

Along with its links to political figures, poetry was also of course an important medium of expression for religious figures. As we have seen, several of the major figures of Awrangabad - including Shāh Mahmūd, Kāmgār Khān and Shāh 'Alī Nehrī (d. 1177/1764) - featured in the poetic anthologies produced in the city. In this sense, poetry illustrates the way in which literary, religious and political figures interacted and in some cases occupied the same social stratum. One of the daughters of Nizām al-dīn, for example, was married to the poet Sayyid Sharaf al-dīn Khān, who authored a mathnawī entitled Ghawth al-samdān $\bar{\imath} .{ }^{68}$ But the most fitting example was the patron of the great pool at Panchakkī, Jamīl Bēg Khān (d. 1179/1765), who 
when not serving beside Nizām al-Mulk wrote poetry under the pen name (takhallus) of Khwāja. ${ }^{69}$ Aside from such literary companions of Nizām al-Mulk, there also existed the literary circle of his son and successor Nāsir Jang, who left a poetic anthology (dīwān) using the pen names of Âftāb and Nāsir. In addition to its connections with the great Āzād Bilgrāmī, Nāsir Jang's circle also included the Sufi and mathnawi poet Shāh Ghulām Husayn (d. 1176/1762). ${ }^{70}$

However, the most significant of all of the poets of this period in Awrangabad was Sirāj al-dīn Husaynī (d. 1177/1766), whom we have already encountered in connection with Nizām al-dīn. Sirāj was born in Awrangabad, where in the years after the establishment of Nizām al-Mulk's independence he developed an attraction for the ways of the dervishes of the city and began to compose poetry. As we have seen, he took to visiting the Sufi shrines of the region, particularly that of Burhān al-dīn Gharīb at Khuldabad and probably also the new shrines that we have seen being constructed in Awrangabad during the years of his youth. The mystical quality of Sirāj's poetry is well-known, as is the tradition - echoing in poetic form the ecstatic utterances $(s h \bar{a} t h)$ of the Sufis of old and the tales of the composition of the mathnaw $\bar{\imath}$ of Rūmi - that his verses were spoken in a state of ecstasy and immediately written down by his followers. Despite this, his work demonstrates clear evidence of sustained craftsmanship, not least in the most famous of his mystical poems, the extensive mystical mathnawī entitled Bustān-e-khayāl. The tradition telling of his renunciation of poetry as an obstacle in the path of his spiritual development at his Sufi master's command eloquently underlines the interdependence of Sufism and literary composition. For in the case of Sirāj, we see the rigours and contrasts of the Sufi life both in terms of the ecstasy of poetic inspiration and the ultimate act of literary control through the rejection of writing altogether.

After the transfer of the Āsaf Jāh capital to Haydarabad in 1178/1763, many of Awrangabad's courtiers and literary figures departed to the new centre. There the patronage of Persian and Urdu letters continued unabated, ranging from connoisseurial treatises on horticulture to the spate of dynastic histories which abounded at the court of Nizām 'Alī Khān (r. 1175/1761-1218/1803). Yet during the first decades after the court's departure, Awrangabad was able to maintain a rich if diminishing literary tradition. Gathered around such stalwarts as Āzād Bilgrāmī, Awrangabad's poetic tradition was able to continue on a lesser scale despite the disappearance of the city's wealthiest patrons. For their part, Sufi biographers were able to use the memory of the saints to invoke the status and noble history of the city. A major characteristic of this literature was an ambiguous sense of both the connection and separation of the new Āsaf Jah state from the politics and culture of the Mughal state that had reared it. We have noted that with the emergence of the new Āsaf Jāh state, the literary assembling of a glorious regional past became a matter of importance, as was also the case with the foundation of other Muslim successor states at Rampur and Maysur around the same time. ${ }^{71}$ An important role in this process was played by writers of commemorative writings (tadhkirāt), particularly works preserving the memory of the early notables and poets resident in Awrangabad. Besides the well-known Sirāj, around whom there had gathered a considerable circle of poets in Awrangabad, the 
poets Mahrām, Fazlī and the son of Āzād Bilgrāmī, Dhakā, were all celebrated in Awrangabad during this period. While, reflecting the sources of its patronage, the greater part of this literature celebrated a past populated by notables and kings, Sufi saints were also seen as an important and appropriate element in a past that was worthy of a proper Muslim dynasty. Yet sainthood featured by no means only within the pages of its own distinct literary creations and references to Muslim saints cropped up in a variety of literary contexts. As well as the aforementioned anthologies, another good example is the Ma'athir-e-Nizāmī, the biography of Nizām al-Mulk written by his Hindu bureaucrat Lālā Mansārām, which contained many references to the Sufis of the Deccan. ${ }^{72}$ However, despite the clear evidence of Nizām al-Mulk's connections with a variety of Sufis, there was no mention of the Sufis in his last testament (wasiyat $n \bar{a} m a$ ) perhaps other than a vague pious reference to the 'lords of God' (arbāb-e-allāb). ${ }^{73}$

\section{Sufi writers of the mid-eighteenth century}

Hagiographical works were not the only genres addressing Sufi matters to be composed in Awrangabad between the 1720s and 1760s, that is during the reigns of Nizām al-Mulk and his early successors. The main works of Sufi doctrine written in the city did not emerge directly from the sajjäda nashins of the new Awrangabad shrines, but from Sufis connected to traditions beyond the city (often from older Sufi centres elsewhere in the Deccan) who were attracted to Awrangabad by the presence of the Āsaf Jāh court. Several Persian Sufi works from this period are extant in manuscript, some of which were dedicated to Nizām al-Mulk or his heirs. One of these is the Anwār-e-tajalliyāt of Muhammad Haydar. ${ }^{74}$ This work was concerned with the mystical elucidation of the core Islamic dogma of Divine Unity ( $t a w h \bar{\imath} d)$. But in India at least, by this point in history this dogma had become almost inseparable from the mystical elaboration of the theme expounded by Ibn 'Arabī (d. 638/1240) of Mursiyya and his heirs. Muhammad Haydar's work thus moves early on into a discussion of the doctrine of the Unity of Being (wabdat al-wujūd); the writer attempts to simplify his exposition by regular recourse to the popular Sufi epithet that 'All is He [God]' (hama üst). ${ }^{75}$ Nonetheless, Anwār-e-tajalliyāt remained a technical work, with discussions of the Sublime Essence of Reality (dhät-e-haqq-e-subhāna ta'ālā) and plenty of Arabic quotations of the Quran and Hadīth to sanction the doctrine espoused. As in the Mishkat al-anwār written by al-Ghazālī over six centuries earlier, the classic Sufi example of the light of the sun $(\bar{a} f t \bar{a} b)$ and its reflection (aks) are used to distinguish contingent being and self-sustaining light qua being. ${ }^{76}$ Although the work was very much an exposition of the thought of Ibn 'Arabi - discussing such points of his cosmology as the World of Likenesses ('allam-e-mitha $\bar{a}$ ) - the doctrine was nonetheless presented in a form passed on by the Sufis of Khurasan (such as the poet Jāmī of Herat) and, more locally, of the Deccan (such as the family of Gēsū Darāz of Gulbarga). ${ }^{77}$ Muhammad Haydar summed up the core of the doctrine with the words 'this whole collusion of things is One' ('̄n majm $\bar{u}^{\prime} a-e-s h a y$ wahid ast). ${ }^{78}$

What is interesting about the Anwār-e-tajalliyāt is its vindification of the doctrine of the Unity of Being (wabdat al-wujüd) against the background of the rise of the 
alternative theory of the Unity of Witnessing (wabdat al-shubūd) offered by the great Naqshbandī renewer Ahmad Sirhindī (d. 1034/1624) and his followers in India. As we saw in Chapter 1, Awrangabad had earlier played host to a significant part of the debate surrounding Sirhindī's ideas. But in Muhammad Haydar's work we see the continued importance in public life of Ibn 'Arabî's doctrines. Indeed, what is also significant about the Anwār-e-tajalliyāt is the fact that while several Sufis do feature as exponents of the Unity of Being, Ibn 'Arabī himself is never mentioned in the work. Far from seeing himself as taking part in a theological debate between different doctrinal positions, Muhammad Haydar seems rather to have regarded his treatise as an exposition of a timeless truth that was recognized by a range of Sufi 'witnesses' over the centuries. The Unity of Being was not in this sense identified as the specific teaching of Ibn 'Arabī (who in any case does not seem to have used the term in his own writings), but rather as a central - albeit advanced and esoteric dimension of normative Islam.

Another Sufi work written in Awrangabad during this period was the Risāla-ye-

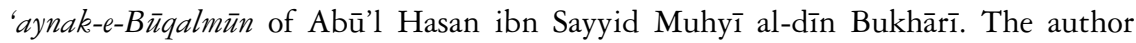
completed this work in $1172 / 1759$ as a record of the teachings of his late master, Hāfiz Shāh Muhammad Ibrāhīm (d. 1170/1756). Although both author and teacher are otherwise unknown, references in the text to earlier Chishtī Sufi masters from North India and the Deccan suggest that the work emerged from a Deccani Chishtī tradition. ${ }^{79}$ While the author seems to have moved to Awrangabad in search of patronage, it is possible that he had connections with Nizām al-dīn's tradition in the city, though there is no suggestion that this was the case. Dedicated to Nizām al-Mulk's son and eventual successor Salābat Jang (r. 1164/1751-1175/1761), the Risāla-ye-'aynak-e-Būqalmūn was in part a Sufi exegesis of the sayings of the Prophet Muhammad. Although beginning with discussions of such key Muslim practices as formal worship, and referring constantly back to the Hadith, the treatise was essentially concerned with the achievement of mystical states of encounter and conjunction (wisāl) with the Prophet. While the Anwār-e-tajalliyāt that was dedicated to Nizām al-Mulk was primarily a work of mystical theory, the Risāla-ye-'aynak-e$B \bar{u} q a l m \bar{u} n$ addressed to his successor was by contrast an exposition of mystical practice. As so often in Islamic mysticism, questions of ontology were of central importance; in this case the Prophetic Being (wujūd-e-nabj) played a central role in the text. In the sole extant manuscript of this work - copied in fine nast'alì $q$ script with gold leaf in plenty by the calligrapher Shaykh Mīrān in the year of its composition - the author's instructions on meditative practice are accompanied by highly unusual graphic representations (sürat) of the visions appropriate to each stage on the mystic path. Eight of these illustrations feature in the manuscript, each accompanied by instructions on and descriptions of the various practices and stages on the journey towards the Prophetic Being. ${ }^{80}$ Seven of the illustrations comprise an image of a seated man formed from the Arabic letters of the name Muhammad, with the images gradually 'purified' to move from the darkness of the lower stages of the mystical journey through the different levels of the physical and subtle body towards the inner Illuminated Spirit (rüh-e-munawwar). Various kinds 
of divine remembrance (dhikr) are described, including the Labour of the Heart (shughl-e-qalbī) in which the name of Allāh is envisioned in the mystic's heart, while the esoteric dimensions of other Muslim rites (such as ablutions) are also discussed in detail. ${ }^{81}$

As well as these two Sufi writers, the family of Shāh 'Ināyat Allāh (d. 1117/1705) of Balapur in the northern Deccan (whose tradition was first established under Mughal patronage) was also drawn southwards to Awrangabad during this period. Just as Sufis were originally attracted to Awrangabad as a consequence of its early prominence under Awrangzeb, the same process continued under Nizām al-Mulk and his successors. Mawlānā Qamar al-dīn of Balapur was one such Sufi. Qamar al-dīn was the grandson of 'Ināyat Allāh and the son of the latter's sajjāda nashīn, Shāh Munīb Allāh (d. 1161/1748). The reasons behind his leaving Balapur are uncertain, but it seems probable that he was a younger son and so unlikely to inherit his father's position as head of the Naqshbandī khanaqah in Balapur. Qamar al-dīn moved to Awrangabad in 1155/1742, but two years later decided (like Fakhr al-dīn around the same time) that Delhi would be a more suitable place for his talents. However, after a short residence in Delhi and then Lahore, he returned to Awrangabad, where he established himself as a religious scholar in the Naqshbandi tradition. ${ }^{82}$ His reputation as a figure of learning soon spread in Awrangabad, and he seems to have received the patronage of the future Nizām, Sikandar Jāh. Qamar al-dīn also became a close friend of Āzād Bilgrāmī and through him, if not through his own Naqshbandī affiliation, he was associated with the headquarters of Awrangabad's already established Nasqshbandī tradition at Panchakkī. Qamar al-dīn died in Awrangabad in $1193 / 1779$.

Qamar al-dīn's literary output was extensive and included a lengthy mystical commentary in Persian on several verses of the Quran entitled Nür al-Karimatayn. More interesting, however, was his Arabic treatise Mazhar al-nūr, which he composed in Awrangabad around 1164/1750 and which consisted of a history of Islamic mystical theories of light $(n \bar{u} r)$. In its spirited defence of the doctrine of the Unity of Being, Mazhar al-nūr reflected the Anwār-e-tajalliyāt of Muhammad Haydar. Qamar al-dīn's text reflected a long tradition of light mysticism in Islam, stretching from the early treatise of Sahl Tustarī (d. 283/896) and the Mishkat al-anwār of al-Ghazālī (d. 505/1111) to the Kitāb hikmat al-ishrāq of Shihāb al-dīn Suhrawardī (d. 587/1191) and the writings of Ibn 'Arabī. The ideas of Ibn 'Arabī had been transmitted between scholarly Sufis in India over the centuries to also reach Shāh Kalīm Allāh, the master of Nizām al-dīn, in Delhi in the generation before Qamar al-dīn. As noted above, in the time of Awrangzeb, Ibn 'Arabī's theory of the Unity of Being (wabdat al-wujūd) had been famously rejected in favour of a less controversial notion of the Unity of Witnessing (wahdat al-shubīd) by Ahmad Sirhindī, whose letters later came into the possession of the Panchakki library. We have seen in Chapter 1 how Sirhindī's ideas had already been criticized in Awrangabad during his own lifetime in the Mukhtasar ma'ärij al-wilāya of 'Abd Allāh Khwēshgī, but the Mazhar al-nūr of Qamar al-dīn is more interesting in being written by a Naqshbandī figure associated with the lineage of Sirhindī himself. For in his text, after surveying and classifying 
all of the available Muslim ideas on light, Qamar al-dinn finally came down on the side of Ibn 'Arabī to conclude that the theory of wabdat al-wujüd presented the most convincing interpretation. Yet 'Abd Allāh Khwēshgī and Qamar al-dīn were only part of a wider repudiation in Awrangabad of the teachings of Sirhindi that was connected to the more general discussion of the claims of the Sirhind $\overline{1}$ that stretched between Delhi and Mecca.

Qamar al-dīn's learned contribution to Awrangabad's Sufi tradition was continued by his son, Nūr al-Hudā (d. 1203/1788). Along with several other works, he wrote long commentaries (basshiyya) on both of his father's major treatises. A celebrated scholar in his own lifetime, Nūr al-Hudā was also a friend of Bilgrāmī, who made mention of him in his Subhat al-marjān. ${ }^{83}$ After his death, Nūr al-Hudā was buried in Awrangabad in a small shrine complex next to the Nawkhanda palace of the Nizāms. The Naqshbandīs of Balapur continued to maintain their connections with Awrangabad, and other members of the family who were based in Balapur visited Awrangabad during this period. Muhammad Ma'sūm Naqshbandī (d. 1235/1820) was sent from Balapur to receive his education in Awrangabad at the hands of his relative, Qamar al-dīn, while at least one of the Awrangabad Naqshbandīs visited the shrine at Balapur in turn. ${ }^{84}$ Another Sufi migrant to find his way into the circle of Qamar al-dīn in Awrangabad was Shāh Ghulām Husayn (or Hasan) (d. 1176/1762). ${ }^{85}$ Ghulām Husayn was a follower of Shāh 'Alī Razā Gujarātī who migrated to Awrangabad and acquired there the following of many of the city's elites, possibly including Nizām al-Mulk's successor, Nāsir Jang. In Awrangabad, his wealthy followers helped him to construct a large khanaqah and a mosque. During his years there, Ghulām Husayn completed an abridgement (mukbtasar) of the Mathnawi of Rūmī and several other poetic works; some of his verses were recorded in Shafíq Awrangābādī’s Gul-e-Ra'nāa. In one of these, he composed versified admonitions to his son and successor, Jamāl Allāh, which was just as well in that the later prosopographer Malkāpūrī tells us that Ghulām Husayn's other son was a notorious drunk.

In Qamar al-dinn's family tradition we are able to glimpse the role that Arabic scholarship played in Awrangabad. This tradition was also exemplified in the career of Bilgrāmī, who in addition to his Persian works composed numerous works in Arabic of a religious nature and, indeed, was one of the major figures in the history of Indo-Arabic literature. But despite their prestige, such works were never as important or indeed as comprehensible among the city's residents as the Persian texts. Partly this reflected the relatively smaller reading circles within which Arabic scholarship circulated, but it was also a reflection of the often highly abstruse theoretical nature of such texts. By contrast, the narratives contained in the Persian hagiographical tadhkirāt were able to engage with a wider oral tradition of stories of the saints, with written text and spoken tale each informing and shaping the other over time as a result of the common narrative imagination of the oral and written hagiographical worlds. Stories of the saints also possessed a malleable capacity for affirming the identities of social groups or even states, enabling them to be easily tied into wider narrative traditions of family, city or state history. Neither case was true of Sufi theoretical writings and it is therefore perhaps unsurprising that far fewer such texts 
have survived in comparison with hagiographies. Like the meditational treatise of Nizām al-dīn, the theoretical works of Qamar al-dīn and his son certainly reflected an important strand in the Deccan's cultural life. But such texts were never able to embed themselves into the life of Awrangabad's inhabitants to anything like the same degree as the miraculous tales of wonder contained in the hagiographical works.

\section{The politics and patronage of praise}

The mid-eighteenth century witnessed a considerable flourishing of texts praising the saints of Awrangabad and its surroundings as a whole. These texts contrast vividly with the Malfüzät-e-Naqshbandiyya and the Absan al-shamä'il, with their devotion to specific Sufi traditions and their authorship by Sufis closely connected to the saints whose lives they celebrated. The texts under discussion in this section were rather part of the wider project we have seen under the early Āsaf Jāhs of celebrating the splendours of their main urban centre at Awrangabad. As such, they were concerned with more than one saintly tradition, and as often as not were more interested in the visual and wider aesthetic appeal of their shrines than with questions of metaphysics or piety. They were, moreover, penned by writers who possessed no distinct links to any tradition, and who may better be regarded as primarily men of letters than as Sufis. Reflecting the position which the shrine of Shāh Nūr had managed to achieve on the city's pilgrimage circuit, the period saw literary gains for Shāh Nūr, who possessed no early documentation to rival Shāh Musāfir and Nizām al-dīn. But the period also witnessed the consolidation of the textual heritage of Nizām al-dīn himself. While the texts written by the contemporaries of the Sufis that we have discussed in Chapter 1 still discussed their subjects as living and very human albeit elevated individuals, the period examined in this section saw their transformation into figures of incontestable sainthood. For as we have stressed earlier, the literary process by which this was achieved was one deeply connected to the erstwhile status of their city as the birthplace of a new state.

This process took shape during the reigns of Nawwāb Salābat Jang (r. 1164/1751-1175/1761) and Nizām 'Alī Khān Āsaf Jāh II (r. 1175/1761-1218/ 1803), when, after the tumultuous years that followed the death of the state's founder Nizām al-Mulk in 1161/1748, the nascent dynasty settled comfortably in the selfconsciousness of its new statehood. Even though Nizām 'Alī Khān left Awrangabad in $1178 / 1763$, the city was able to maintain its status and the following decades saw the composition of some of the most important documents in its history. During this period, a considerable literature emerged detailing the origins and history of the $\bar{A}$ saf Jāh dynasty and bedecking its early representatives with all the literary accoutrements of kingship. Integral to this programme of literary patronage was the emergence of a retrospective literature highlighting the glories of the region's past, laying particular emphasis in its early stages on Awrangabad as the first capital of the dynasty.

The concern that Awrangabad's writers had during this period with hagiographic narratives relating to the city's Sufi saints and other forms of urban encomia had 
several sources. One of them was an understandable anxiety for the presence of barakat-bearing saints within the new Āsaf Jāh realm. This reflected the eagerness that we have seen in the Malfüzät-e-Naqshbandiyya of the father of the kingdom's founder, Ghāzī al-dīn Khān Fīrōz Jang, for the company of Shāh Palangpōsh, and Nizām al-Mulk's own concerns (as shown in his contemporary Mansārām’s biography of him) for the presence of powerful Sufis in his kingdom. Connected to this was the sentiment that the protection of Sufis and their shrines was one of the proper duties of kingship, as Nizām al-Mulk himself expressly stated in Mansārām's biography. ${ }^{86}$ But underlying these individual behavioural patterns was the more widespread belief that any Muslim city or state should have its own saintly protectors, protectors whose greatness would also contribute to the prestige of the state. The presence of such saintly patrons was as widespread in premodern Islam as in Christendom, including such Indian examples as Salīm Chishtī in Fatehpur Sikri and Ahmad Khattū in Ahmadabad. ${ }^{87}$ In reflection of a trope common to historiography throughout the Islamic world, such figures were often considered as the mystic founders of cities and states. ${ }^{88}$

These concerns were manifested in Awrangabad from the 1170s/1760s onwards through the creation of a retrospective literature celebrating the city's saints and shrines. The main vehicle for this process of transforming the living Sufis of the early documents into the saints of the later ones was the same genre used for the celebration of notables and poets. As we see in the following sections, the biographical texts of saints, poets and aristocrats were frequently created by the same writers, revealing Sufi and saintly discourses as embedded within a wider and shared textual ecumene rather than as the sole preserve of practising Sufis abstracted from the world of wider concerns. This early spate of literary celebrations of the saints of Awrangabad and its environs was followed in the nineteenth century by a long silence in the city. Although Nizām al-dīn, with his wider connections to the tradition of the great Chishtī saints of Delhi, continued to be the subject of biographical entries written elsewhere in India, with the gradual eclipse of Awrangabad by Haydarabad writers found more reason to celebrate the buildings, history and saints of the new capital rather than those of its precursor. The erstwhile Hindu litterateur of Awrangabad (and son of Lālā Mansārām), Lakshmī Narā'in Shafīq Awrangābādī (d. 1809) is a fitting case in point. Having completed several historical and commemorative works, in $1214 / 1800$ he turned his hand to penning a laudatory description of the new Asaf Jāh capital of Haydarabad, giving only short shrift to the qualities of the earlier capital of Awrangabad which was his own home city. ${ }^{89}$ Two decades later, the erstwhile resident of Bidar, Qādir Khān Munshī Bīdarī, penned an urban history of Haydarabad entitled Tawarikb-e-farkhunda. Like these men of the pen, some Sufis also decided to follow the court to Haydarabad. This was the case with the Awrangabad Sufi Ghulām Hasan, who left his hometown to spend several decades as a recluse in the new capital prior to his death in 1214/1799. ${ }^{90}$ Muhammad Ma'sūm Naqshbandī (d. 1235/1820), the Balapur Sufi who studied in Awrangabad with the great Sufi scholar Qamar al-dīn, also travelled to Haydarabad during this period, where he was feted by the shaykhs of the city and met by the third Nizām, Sikandar 
Jāh, who bestowed a land grant ( $j \bar{a} g \bar{\imath} r$ ) upon him..$^{91}$ One important case of Sufi emigration from Haydarabad, however, was the departure of the Ni'mat Allāhī Sufi, 'Abd al-Hamīd Ma'sūm 'Alī Shāh, for Iran in 1190/1776, where, despite his martyrdom there, he was able to initiate the great nineteenth-century revival of Sufism in Iran.

As a literary genre, the commemorative text (tadbkira) has a long history in Sufi circles dating back to the Arabic Tabaqāt al-süfiyya of Sulamī in the tenth century, before passing into Persian and in time Urdu literary expression..$^{92}$ Despite this long history, in which the hagiographical tadbkira predated and quantitatively outweighed certain other forms of Sufi literature, it has until recently received relatively little attention. Yet from what we have seen of Sufi reading circles in the two Awrangabad malfīzāt, such tadbkirāt seem to have been used far more than treatises of metaphysical complexity and many tadhkirāt seem to have been written for a broader audience than other genres of Sufi literature. Tadbkirāt often also reached the audiences of non-Sufis who have for centuries made up the wider constituencies of saintly clients, constituencies which must be seen as an integral part of Sufism as a broad-based social phenomena. Such client groups were the primary context without which the memory of saints or their cults could not survive. This wider audience meant that although still nominally concerned with the lives of saints, tadbkirāt were implicitly more concerned with social and political issues than genres like the technical treatise (risāla) and to some extent the 'recorded conversations' (malfüzāt) composed for more restricted readerships.

An important caveat remains here, for the tadbkirāt remained literary documents and as such possessed only a limited readership among the predominantly nonliterate clientele of the shrines. We have little evidence suggesting for example that their recitation was as important among shrine devotees as we have seen it to have been among formal disciples (murīds). For just as the writings of Shāh Mahmūd and Kāmgār Khān have been seen against their specific contexts of reception, so too must the tadbkira tradition be understood in comparable terms. The first generation of tadhkirāt - including those of Bilgrāmī, Sabzawārī and 'Urūj - were composed in Persian, a language which was in most (though not all) local circles a second language of educated discourse. This is of great importance, in that both Bilgrāmī and 'Urūj were better known as writers of prose works discussing the major political or poetic figures of their age than as primarily religious writers, writers of the very kind of text in which Shāh Nūr was first mentioned by Shāh Nawāz Khān. Similarly, pilgrimage manuals like that of Sabzawārī were also usually composed for an elite clientele. This elite readership is seen in the fact that the eighteenth-century Deccan pilgrimage almanac written under the auspices of Nizām al-dīn by Muhammad Najīb Qādirī Nāgawrī Ajmērī (which also mentioned Shāh Nūr and Shāh Musāfir) was later re-dedicated to Tìpū Sultān of Maysur. ${ }^{93}$ With the development of Urdu prose in the nineteenth century, tadhkirāt were not necessarily created with the aim of bringing letters to the common man, but rather for a comparable, if broader, educated and selfconsciously cultivated audience. Such a perspective is in sharp contrast to the image of Sufism as the voice of the masses reared in much twentieth-century historiography 
in India, showing rather how Sufi texts were composed within the framework of the socially embedded knowledge systems of their day.

The reflection in the tadbkirat of the specific affairs of the social world of their reception is most clear in the more or less explicit roles played by the narrative themes of kingship and bureaucracy. It is in the tadbkira tradition, for example, that images of royal association grow in importance, while the genre in itself may be seen as in some sense a formalization and indeed bureaucratization of sainthood itself. This is reflected not only in tadhkira titles (such as Khazinat al-asfiy $\bar{a}$ ) and their internal structure of providing catalogued inventories of the saintly 'resources' belonging to any given community (whether based on geography or Sufi order), but also in tadbkira narratives and their casts of characters. Thus, in the case of 'Urüj we have the 'prime minister' (wazīr ) of Awrangzeb petitioning Shāh Nūr for help with the affairs of his office. ${ }^{94}$ This process is also well illustrated in the Rawzat al-awliya of $\bar{A} z \bar{a} d$ Bilgrāmī, where this bureaucratization of sainthood is seen in the image of 1,400 saints following the medieval army of 'Alā' al-dīn Khiljī to the Deccan, a holy battalion enumerated, paralleled and shaped into the image of a national resource no less than the soldiers themselves. Although Rawzat al-awliya is concerned with the saints of Khuldabad rather than those of Awrangabad, it is of great importance as the most famous saintly tadbkira written in Awrangabad during the consolidation of Āsaf Jāh rule. Bilgrāmī chose to commemorate the saints of Panchakkī in his Ma'âthir al-kirām, but the Rawzat al-awliyā was written as part of the same process of creating a saintly heritage for the new Āsaf Jāh state that fostered the writing of the tadbkirāt of Sabzawārī and 'Urūj that dealt with the Awrangabad saints.

Although several of Bilgrāmī's works adopted time or the 'age' (dawr, zamān) as their structuring motif, in Rawzat al-awliyā Bilgrāmī instead adopted a fixed territory through time in this role. This reflected the pattern of earlier tadbkira collections like the fifteenth-century Herati Nafabāt al-uns, which were also connected to spiritualized versions of political domains. For just as the creation of pan-Indian tadbkirāt during the political supremacy of the Mughals may be seen as a process of the sanctification of what was in some sense a new and problematic territorial construction, so Bilgrāmī's own textual territorialization of the sacred sites of the Sufi saints fitted into a wider agenda of the consolidation of political power. It was by no means coincidence that Bilgrāmī chose to include amid the saintly biographies in Rawzat al-awliya $\bar{a}$ references to the careers and tombs of the first two Ásaf Jāh rulers who were also buried at Khuldabad and whose patronage he had previously enjoyed.

As the most distinguished of the Awrangabad memorialists, a good deal is known of the life of Bilgrāmī that can shed light on the background to the creation of saintly tadhkirāt under the early Āsaf Jāhs. ${ }^{95}$ Although featuring here as a writer of hagiographies of the saints, Bilgrāmī was generally better known as the writer of an important poetic biographical anthology Khazāna-ye-'amira (1176/1762) and other works in Persian and Arabic. Yet despite winning fame as a writer of such sophisticated anthologies and, living at the centre of the literary life of Awrangabad at the 
height of its Āsaf Jāh revival, becoming the city's grand old man of Persian letters, Bilgrāmī also involved himself in political life and was long an adviser and close companion of Nāsir Jang, the son and successor of Nizām al-Mulk: both of their biographies were included in his Khazāna-ye-'amira. ${ }^{96}$ The latter, alongside the biographies of around a hundred and thirty poets, also devoted a great deal of space to Bilgrāmī's observations on the recent political history of North India and the Deccan, and particularly to the rise of the Āsaf Jāh family. Given the wearying number of Maratha raids on Awrangabad during this period, it is perhaps unsurprising to find that Bilgrāmī also provided a less than flattering account of the rise of the Marathas. ${ }^{97}$ We learn almost nothing in Bilgrāmī's accounts about the relationship of the Āsaf Jāh rulers with the Sufis of their kingdom, though at one point Bilgrāmī does describe Nizām al-Mulk as having 'donned the clothes of the faqīr' (labās-e-faqr pusshida) in Delhi. ${ }^{98} \mathrm{He}$ also describes how all of the religious scholars ('ulamā) and Sufis (fuqarā) of the Deccan served Nizām al-Mulk and that during his reign Sufi shaykhs arrived in the Deccan from Central Asia, Iran, Iraq and the Arab lands, as well as from other regions of India. ${ }^{99}$

Amid a life of literary composition and political intrigue, Bilgrāmī had also been able to live for a while the life of the dervish and spend seven years as a resident of Panchakkī, only leaving the shrine once he had secured the patronage of Nāsir Jang. ${ }^{100}$ On leaving Panchakkī, Bilgrāmī acted in the influential capacity of corrector of Nāsir Jang's poems (i.e. as the prince's ustād or 'master'), though he later came to advise and negotiate in political affairs and was actually present at the assassination of Nāsir Jang in 1164/1750. In the years after his patron's murder, Bilgrāmī returned to a life of scholarly and religious reflection. In 1166/1753 he completed Ma'äthir al-kiram, his account of the holy men and scholars of his home region of Bilgram, in which we have earlier seen Shāh Musāfir and Shāh Palangpōsh's incongruous appearance. Appropriately, Bilgrāmī himself eventually assumed something of the status of a saint, for not only did he feature while he was still alive in Sabzawārì's saintly encomium alongside the other saints of Awrangabad, but after his death in 1200/1786 pilgrimages began to take place to his tomb at Khuldabad which were still being reported in the early twentieth century. According to the British administrator T.W. Haig, 'parents take their children to his shrine in order that they may, by picking up with their lips a piece of sugar from the tomb, obtain both a taste for knowledge and the ability to acquire it.. ${ }^{101}$ As in the construction of a special dome for Shāh Mahmūd at Panchakkī, we see in Bilgrāmī’s burial and subsequent cult the connections between textual production, architectural commemoration and sanctity.

The two saintly tadhkirāt that Bilgrāmī wrote during this period suggest a certain ambivalence towards the status of Panchakki amid the wider sacred landscape of the region. For though Bilgrāmī held Shāh Palangpōsh and Shāh Musāfir in sufficient esteem to break the main geographical focus of his memorial of the wise and holy men of his native Bilgram to include them within it, he had nonetheless been unwilling to bend the same rules to commemorate them in his tadbkira on the saints of Khuldabad, Rawzat al-awliya. ${ }^{102}$ Though made good three decades later in the 
memorial of the saints of both Khuldabad and Awrangabad written by Khāksār-eSabzawārī, this omission may indicate that the status of the Awrangabad Naqshbandīs during this early period was perceived as unable to compete with that of the saints of Khuldabad. Nonetheless, Bilgrāmī's attachment to his erstwhile home at Panchakkī was sufficient for him to compose a qasīda of twenty-one couplets in praise of the pool and fountains that were built there by Jamīl Bēg Khān. ${ }^{103}$ In the poem, Bilgrāmī poured praise in the most eloquent terms on both the pool and the surrounding scented gardens of the shrine, connecting the terrestrial architecture of Panchakki with the gardens of paradise through the language of flowers and the direct comparison of the new pool with the pool of Kawthar in heaven. In the same poem Bilgrāmī also eulogized Shāh Musāfir after the model of the ancient Persian emperor Khusraw, as a king who lacked only the crown, signet ring and standard (tāj wa nagin wa 'alam) of an emperor. Reflecting the legends that would also later develop around Nizām al-dīn, Bilgrāmī also presented Shāh Musāfir as the kingmaker $(t \bar{a} j-d a b)$ of the rulers of Rome, China and Persia. While this was praise indeed, it was nonetheless praise with a political edge.

The contours of Bilgrāmī's career show how sainthood and politics stepped between the textual world of written documents and the real world of the contexts which helped shape them. Although we do not possess comparable evidence on the life of Bahā' al-dīn Hasan 'Urūj (d. c.1230/1814), his more widely known literary identity as a writer of poetic anthologies alongside his assumption of the pen name (takballus) of 'Urūj ('Zenith') place him within the same literary sphere as his contemporary Bilgrāmī. In addition to his composition of Khizān $\bar{u} b a b \bar{a} r$, 'Urūj was also the author of the Tadbkirat al-shu'arā on the poets of the Deccan, as well as a poet in his own right. Another of his literary works shows him to have been a member of Bilgrāmı̄’s literary circle in Awrangabad, for in the epistolary manual Payām-e-ulfat, 'Urūj included as models several letters that he had himself addressed to Bilgrāmī. Other addressees included the disciple of Nizām al-dīn’s follower Shāh Ismā‘̄il, Shāh Ghulām 'Alī Chishtī (d. 1210/1795) of Ellichpur in the northern Deccan. When 'Urūj died in Awrangabad around 1230/1814 he was buried in the aristocratic Mughal necropolis in the neighbouring village of Harsul. ${ }^{104}$

\section{Encomia of the city and its saints}

The tadhkirāt reveal much about the changing images and fortunes of the Awrangabad shrines, while also reflecting wider cultural change in the city at large. This is seen most clearly with regard to the saints of Panchakkī, where the urgency of their early commemorative tradition in the writings of Shāh Mahmūd, Bilgrāmī and Sabzawārī was then followed by a long literary silence unbroken until the early twentieth century. A shift was already occurring in the memory of the Naqshband $\overline{1}$ shaykhs by the time of Bilgrāmī, whose memorial contains early signs of the standardizing and stylizing process of hagiographical literary transformation. ${ }^{105}$ There is, for example, an emphasis on prodigious childhoods, saintly titles and the 
acquisition of different sources of sanctity (including a probably spurious early hajj) that reflected the beginnings of a transformation from the sharply individualistic and carefully observed anecdotes that distinguish the Malfüzāt-e-Naqshbandiyya into the standardized tropes of more typical tadbkira collections. ${ }^{106}$ Together, the Malfüzāt-eNaqshbandiyya and the Ma'äthir al-kirām show a frozen moment in the textual process of Muslim saint-making, a moment preserved midway between the undoubted idiosyncrasies of two living Sufi masters and the more standardizing image of the Muslim saint. The picture of the cult of Awrangabad's Naqshbandīs preserved in the slightly later Sawānih (c.1189/1774) of Sabzawārī fills in some of the missing context of the accounts of Shāh Mahmūd and Bilgrāmī (who was still alive when Sabzawārī was writing). We have no information as to who Khāksār-eSabzawārī was, though given the shrine connections of the other writers of the period, it seems possible that he may have been connected to the shrine of the Sufi ecstatic (majdhūb) Shāh Khāksār at Khuldabad. Bilgrāmī described this figure as having come from Bijapur during the reign of Awrangzeb to live on one of the hilltops of Khuldabad, also mentioning that his shrine was established there after his death. ${ }^{107}$ As we have seen earlier, the Sawānih described Panchakkī as a place of considerable Sufi activity, with its khanaqah full of dervishes and with Shāh Sa'īd, the successor of Shāh Mahmūd, leading regular circles of $d h i k r$. Yet for Sabzawārī, the prestige of the shrine came at least as much from its association with the Naqshbandiyya and their wealthy, high-born Central Asian representatives as from the living presence or memory of the saints themselves. With Sabzawārī affording Shāh Palangpōsh and Shāh Musāfir no further description than the conventional repetition of the poetic chronograms penned for the saints by Bilgrāmī, a process was already beginning of the eclipse of the now dimly perceived saints by the built presence of their splendid shrine.

The emergence of Shāh Nūr into the saintly tadbkira tradition found him already partly assuming the hagiographical attributes of the Muslim saint. In the brief discussion of Shāh Nūr in the Ma'āthir al-umarā of Shāh Nawāz Khān, the living dervish was remembered vividly enough to be presented in a manner more mortal than saintly, as an enlightened living dervish from India's north-east. ${ }^{108}$ The other early textual reference to Shāh Nūr, in the visit of Shāh Musāfir to the shrine of Shāh Nūr mentioned in the Malfüzāt-e-Naqshbandiyya, suggests that the cult of Shāh Nūr was flourishing soon enough after his death in 1104/1692 for Shāh Musāfir to have made his visit prior to his own death in 1126/1715. ${ }^{109}$ This chronology is in itself proof of the speed at which shrine cults could develop. By the time of the writing of 'Urūj's Bahār u Khizān some time after 1189/1775, in which Shāh Nūr's life was first described in detail, Shāh Nūr was being described as a child prodigy, who had mastered esoteric learning ('ilm-e-battin $\bar{l}$ ) in his early years and, in a classic hagiographical foreshortening of ordinary childhood, undergone his first Sufi initiation at an early age. ${ }^{110}$ Like Shāh Palangpōsh in Bilgrāmī’s account, Shāh Nūr was also described as having been a childhood ecstatic and holy fool (majnūn), reflecting Bilgrāmī’s reference to Shāh Palangpōsh's youthful nickname of 'crazy Sa 'îd' due to his being always under the influence of ecstasy $(j a d b b) .{ }^{111}$ 
This development of a grander saintly identity suggests another parallel with Bilgrāmì's text, itself here fulfilling one of the key concerns of the tadbkira genre in the careful presentation of the different sources of Shāh Nūr's authority. Shāh Nūr's primary source of prestige was geographical and familial, and in contradiction to Shāh Nawāz Khān's assertion that Shāh Nūr probably came from the Pūrāb, 'Urūj opted for a more edifying homeland for the saint in declaring that Shāh Nūr was born in Baghdad as the son of Sayyid 'Abd Allāh Hamadān̄i, a Husaynī sayyid. This geo-spiritual presentation of the saint's authority was further embellished with details of his travels to Egypt (where he was claimed to have resided for nine years), before moving to Madina. ${ }^{112}$ After making the hajj to Mecca, he was presented by 'Urūj as having travelled to the early Mughal outpost in the Deccan and important Sufi centre of Burhanpur, before travelling to Ahmadpur and thence to Awrangabad at the time of its foundation. ${ }^{113} \mathrm{He}$ was described as having made the hajj several times more, and during one visit to have disappeared for an entire year before returning with descriptions of meetings with the Green Man of Islam, al-Khizr, and the semi-legendary early Sufi, Ibrāhīm bin Adham. ${ }^{114}$ His meeting with this early figure is explained through lending him a fantastically long life stretching over several centuries before his eventual death in Awrangabad during the reign of Awrangzeb. In these descriptions, 'Urūj, like Bilgrāmī and other memorialists before him, carefully delineated the sources of his chosen saint's authority. At the same time, he provided a new identity for the saint within the terms of the religious and ethnic strata of Indo-Muslim society, defining Shāh Nūr for the first time as an immigrant Husaynī sayyid, an ancestry that would place Shāh Nūr at the top of the Indo-Muslim social hierarchy of the ashräf. He also added details to the saint's specifically Sufi identity through mention of his early initiation, without actually specifying details of which of the Sufi orders he belonged to.

Perhaps of greatest interest is 'Urūj's emphasis on the saint's arrival in Awrangabad just as it was being founded. For here he presents the image of Shāh Nūr as the patronal founder saint of the city. The text informs us that when Awrangzeb founded the city in 1068/1657, Shāh Nūr was already 170-years old. The saint recalled having seen the city in the days 'when there was nothing there but kikar trees and desert' and only stopped his wandering when the city was properly settled. ${ }^{115}$ Moreover, bringing with it the approval of divine ordination, the saint's journey to the Deccan was described as having taken place at the Prophet Muhammad's command. ${ }^{116}$ Shāh Nūr is also quoted as mentioning a period of residence in Agra and Delhi, drawing further prestige from association with the father cities of Awrangabad that were the earlier capitals of Akbar and Shah Jahan. ${ }^{117}$ It was through this series of images and associations that 'Urūj fashioned Shāh Nūr into the role of the city's sacred founder, a desirable personage for a new capital city whose origins and early history 'Urūj and his contemporaries were giving literary form. As much a part of the late eighteenthcentury literary movement that created a heroic saintly heritage for the new Āsaf Jāh state as Bilgrāmī's Rawzat al-awliyā, 'Urūj's tadhkira of Shāh Nūr brought together images of saintly genealogy and the foundation of the city into a narrative sequence that echoed the political movements whose shadows they were. 
'Urūj's hagiography is also the earliest source of a story which later became the most famous of the legends concerning Shāh Nūr. ${ }^{118}$ The story is of particular interest for its Indian imagery, painting the Sufi in narrative colours applied equally to the Yogis. In 'Urūj's version, Shāh Nūr was performing one of his regular sessions of meditative breath control (babs-e-dam); these usually lasted from between 5 and 12 years. On one occasion he was performing this austerity in a pit, which as the years passed became filled with earth so that he was no longer visible. By chance, some Hindu travellers passed by the spot, and their guru informed them that it was a good place for meditation. As a result, they placed a statue there, which over time attracted many other groups of Hindus to worship; little did they know, the text informs us, that they were actually receiving the blessings of Allah while worshipping the statue. Some years later, a nephew of Shāh Nūr set off from his home in Hamadan in Iran to search for his uncle, and attracted by his saintly odour, eventually reached the site of the statue. Seeing what was happening there, he immediately tried to smash the idol in order to exhume the saint. Naturally, the Hindus objected and a dispute broke out, in which the two sides competed with their powers of miracle and magic. Nonetheless, the head guru of the Hindus came to the nephew and asked him why he wished to destroy the statue. Shihab al-dinn explained that his uncle was buried there, and on hearing this the guru himself performed a meditation (murāqaba) on the spot in order to test the claim. In a narrative resolution that echoes the theme of the common goal of Hindu and Muslim devotion found elsewhere in Shāh Nūr's tradition, the guru came by his own means to see the truth of the Sufi's nephew's claims. The guru then told him to call Shāh Nūr, at which point the nephew sank into a deep state of mystical concentration (khās tawajjuh). After crying out Shāh Nūr's name and the Muslim call to prayer the earth then began to tremble, before splitting open to reveal the saint buried underground in rapt meditation and surrounded by a great cloud of smoke. Again his nephew repeated the call to prayer and the saint slowly became conscious. On seeing this, the Hindus accepted Islam and the guru became a close follower (murīd) of Shāh Nūr, lived with him for eight years and became a great master of mystical unveilings and miracles (kashf $\bar{u}$ karāmāt) in his own right.

'Urūj went on to describe several more of Shāh Nūr's remarkable miracles in detail, including a period of no less than seventy years spent buried underground in breath control, the healing of a follower suffering from dysentery through the unexpected medicine of a hot kebab and the summoning of a vision for his disciple Diyānat Khān of his home in distant Agra. ${ }^{119}$ (Strangely enough, Diyānat Khān had already entered a much wider narrative tradition in his own right, his fame such that he had featured as 'Diyanet' - in John Dryden's versified play Aureng-zebe, written in London in 1676, a full century before 'Urūj's more local account of the dīwān's deeds.) 'Urūj's miracle accounts need to be seen in the context of the shrine as a purveyor of miraculous healing and assistance, for such texts cannot be fully understood without reference to the cultural practice of shrine veneration and pilgrimage. The foundation of the shrine in Awrangabad thus played a considerable role in the text, as did an account of the sajjāda nashinns of Shāh Nūr, aimed at establishing their relationship to the saint. ${ }^{120}$ Reference to correspondences between specific ritual practices and the 
customs of the saint - such as in the locating of the origins of the Wednesday pilgrimage to the shrine with Shāh Nūr's habit of leaving his meditations in his retreat (bujra) on that day to meet the people - further position the text within the context of a flourishing cult of sainthood in Awrangabad.

It was in the context of this cult of pilgrimage that Shāh Nūr also featured in the Sawānih of Sabzawārī. Sabzawārī provided several fascinating accounts of the celebration of the death anniversaries of the saints of Khuldabad in the second half of the eighteenth century. At the shrine of Muntajib al-dīn Zar Bakhsh, he described the performances of Sufi praise-singers (qawwäls) all through the night, and people climbing to the neighbouring hilltop to gaze down in delight at the festive lighting (chirāgha $\bar{a} \bar{\imath}$ ) of the shrine. ${ }^{121}$ All of the people of Awrangabad were portrayed as travelling out to Khuldabad to attend the 'urs of Burhān al-dīn, while at the death anniversary at the neighbouring shrine of Zayn al-dīn Yogis were described as deliberately burning their noses with candles. Others gathered to watch the performances of dancers and wrestlers. ${ }^{122}$ After accounts of the Chishtī saints of Khuldabad, Sabzawārī in turn described the cityscape and finally the saints of Awrangabad. Awrangabad itself was given lavish and extensive praise as 'a second Shahjahanabad [i.e. Delhi]', with descriptions of its markets, mosques and other architectural features making it clear that the Sufi saints were to be similarly regarded as treasures of the city. In this sense, the Sawanih resembles such urban panegyrics as the Jalwa-edìdār of Hazwar Muhammad 'Āqil (d. 1143/1730), a text celebrating the buildings, markets and shrines of Delhi.

Awrangabad's shrines were of paramount importance to Sabzawārìs account, the architectural majesty of their domes, courtyards and pools described in detail as the concrete manifestation of the power and the glory of the saints. Yet as it would also lead later hagiographers, this led Sabzawārī to an awkward paradox. For while he did not dispute the unrivalled architectural splendour of Panchakkī, which appeared first in his account of the Awrangabad shrines and whose every decorative feature he extolled in detail, he nonetheless had nothing to say about either Shāh Palangpōsh or Shāh Musāfir themselves. Shāh Nūr, however, received far more praise, the lavish description of his 'urs confirming his early position as chief among the city's saints, and enabling Sabzawārī to maintain a balance between the presentation of saint and shrine. ${ }^{123}$ In contrast to the Arabian saint described by 'Urūj, in Sabzawārî's account Shāh Nūr remained the more local figure associated with hammāms and the possession of miraculous powers. Probably drawing on an existing oral tradition among the saint's extensive clientele, Sabzawārī thus presented Shāh Nūr in the guise of a master qalandar, ever busy in divine remembrance and enamoured of the desert wilds. 


\title{
THE SUFIS IN THE SHADOW OF A NEW EMPIRE
}

\begin{abstract}
Nawwāb Nizām al-Mulk was a student (tālib) of Nizām al-dīn and had complete discipleship and faith. One day Nizām al-Mulk held a celebration for a newly built house and invited him by giving him a note of supplication ( $\left.r a q^{\prime} a-y e-n i y \bar{a} z\right)$. But Nizām al-dīn sent the note back in decline, writing upon its back, 'You are as a child and our dwelling place is full of colors (khāna rangīn ast). ${ }^{1}$
\end{abstract}

\section{The British, the Nizāms and the Saints}

Due to the proximity of Awrangabad to the borders between Āsaf Jāh territories and the domains of the Marathas, early in his reign Nizām 'Alī Khān (r. 1175/17611218/1803) transferred his capital from Awrangabad to Haydarabad. ${ }^{2}$ There from the 1760 s he and his courtiers set about patronizing the city that had been founded a century and a half earlier by the Qutb Shāh rulers of Golkonda whom Awrangzeb had defeated in 1098/1687. In many ways there was also a symbolic quality in the move to Haydarabad, connecting the rule of the Āsaf Jāhs to the independence of the earlier rulers of Haydarabad whose city they had inherited. Like Awrangabad in the preceding decades, Haydarabad became an important centre for the arts. Nizām 'Alī Khān's reign saw the writing of the great eighteenth-century musical treatise Us $\bar{u} l$-e-naghmat-e-Āsaf $\bar{\imath}$ of Ghulām Razā Khān, for example. Reflecting this patronage of music, Haydarabad also proved itself to be one of the great centres in the history of the raggmala paintings that depicted musical modes ( $r \bar{a} g$ ) in pictorial form. Such diverse arts had a way of drawing upon the various aspects of Deccani life. One of the most popular of all the 'female' modes or rāginnis (of which several examples are extant from the Deccan at this time) was Kedar, portrayed as a great ascetic whose renown was so great as to attract even royal visitors. Yet Nizām 'Al̄̄ Khān's court also sponsored a series of historical works in Persian that glorified the achievements of the Āsaf Jāh dynasty and gave literary credence to the right of the Āsaf Jāhs to rule the entire Deccan. These included such works as the $M a^{\prime} \bar{a} t h i r-e-\bar{A} s a f \bar{\imath}$ (1208/1793) of the migrant scholar from Awrangabad, Shafīq Awrangābādī, the Āsafnāma (c.1206/1792) of Nizām 'Alī Khān's favourite, Shāh Tajallī 'Alī, and the Târīkh-e-dil afrūz (c.1218/1803) of Ghulām Husayn Khān Jawhar. In leaving its first capital of Awrangabad, in Haydarabad the 
state founded by Nizām al-Mulk broke from the Mughal shadows of its infancy and finally came of age.

Despite the pomp of his court and the much-needed stability which his longevity would give to his subjects, the long reign of Nizām 'Alī Khān was often forced to buy its survival at a high cost. Nizām 'Alī Khān was certainly a shrewd politician and like other Muslim rulers of the period was keen to engage with the new technologies that he could see had aided the Europeans so well. Writers like 'Abd al-Latîf Shushtārī in his Tuhfat al-'alam (1217/1802) brought news to his court of the latest European developments in science, while Nizām 'Alī built on earlier Mughal practice by employing the Frenchman Michel Raymond (d. 1798) as his controller of ordinance (amīr-e-jinsī). Yet the rise of Haydar 'Alī and his successor Tīpū Sultān in the southern Deccan brought the final loss of the southernmost portions of his domains. Tīpū's eventual defeat in 1213/1799 by the British in alliance with Nizām 'Alī led to a series of compromises which resulted in tying the Nizām and his successors into an 'alliance' with the British that rendered the British Resident in Haydarabad the most influential figure in the politics of the state. The first British representative in Haydarabad in 1779 was John Holland and later representatives would wield far greater influence than he did. But this was not yet the heyday of British imperialism and the attractions of Mughal court culture that survived in Haydarabad were such that numerous Europeans in Haydarabad would succumb to its charms. And so the Resident James Achilles Kirkpatrick fell in love with the daughter of one of Nizām 'Alī Khān's courtiers and converted to Islam in order to marry her. ${ }^{3}$

From their outpost in Haydarabad, British agents began to collect data on the government of Nizām 'Alī Khān and his predecessors which would contribute not only to the consolidation of British control over India but also to the vilification of Indo-Muslim cultural and political life that was its intellectual counterpart. It was from Haydarabad that Captain James Grant set out to complete his unpublished Political Survey of the Deccan in 1782 in which he and his local assistants compiled a mass of data on the past and the present government of the Deccan through direct observation and the translation of existing Persian revenue documents and historical works. Grant's attitudes towards the literature that he surveyed provide a bleak insight into the early colonial mentality of the British. The Persian historians of the Deccan, he wrote, 'furnish very little entertainment for rational curiosity, still less for philosophical enquiry, \& are disgusting to humanity'. ${ }^{4}$ Blind to the evident and tremendous wealth of Persian and Urdu literature in the Deccan, Grant's prejudices led him to declare that 'it cannot be imagined that the Arts \& Sciences have received any improvement in the Deccan from the genius or labors of its Musulman inhabitants'. ${ }^{5}$ And despite the obvious success of Indo-Muslim polities in governing much of India for the previous seven centuries, Grant characterized Muslim rule as by nature 'despotic'. In a chilling prefiguring of later European rhetoric, in what presented itself as an objective political analysis Grant declared that

A spirit of bigotry and intolerance characterises the believers of the Sonna, or traditions of Mahomet, \& makes them the most dangerous neighbors, as it 
instigates \& gives a sanction to foreign conquest, making religion the cloak of the most unlawful ambition, founded in pride, reared in ignorance \& cherished as presenting new objects of pleasure to the motivating insatiable sensuality. ${ }^{6}$

Having created such a dangerous enemy in a land far from their own, the advice of Grant to his superiors led to its inevitable conclusions. So the Nizām was forced to effectively surrender his independence through a series of treaties and alliances that tied his own survival to that of the British. ${ }^{7}$ The Preliminary Treaty signed between Haydarabad and the East India Company in 1213/1798 compelled Nizām 'Alī Khān to allow British military contingents to be stationed across his domains. Two years later a regiment under British command was stationed in Awrangabad.

In 1218/1803, within a couple of years of the stationing of British forces in the territories of Haydarabad State, Nizām 'Al̄̄ Khān died and was succeeded by the third ruler to bear the title Āsaf Jāh, his son Sikandar Jāh. The reigns of Sikandar Jāh (1218/1803-1244/1829) and his successor, Nāsir al-Dawla Āsaf Jāh IV (1244/1829-1273/1857) witnessed the lowest point in the history of Haydarabad State. ${ }^{8}$ Compelled by the treaties that the Nizāms had signed to accept British 'protection', the cost of maintaining the armies through which the British directed their authority eventually resulted in the effective bankruptcy of the state. To make matters worse, Sikandar Jāh also built up enormous debts to the private bank established in Haydarabad by the British entrepreneur William Palmer (d. 1867). In order to recoup the debts to the British in which the Âsaf Jāh government perpetually found itself, large tracts of Haydarabad's territories (including the whole region of Berar) were later handed over to British control. This desperate financial situation was to characterize the entire first half of the nineteenth century, a period whose woes were made worse by a series of crop failures and famines. It was only with the appointment of the great reformer of Haydarabad's governance, the modernizing politician and notable Sālār Jang in 1270/1853 that the first hopes of improving the state's political and economic subjugation began to appear.

In the early years of the nineteenth century, Nizām 'Alī Khān's treaty with the East India Company led to the stationing of a military contingent in Awrangabad under British command as part of the newly founded Hyderabad Contingent. As in other parts of India, a separate cantonment area was constructed in Awrangabad for the Europeans, who had little contact with the neighbouring old city and its inhabitants. The British officers stationed there, like the young Meadows Taylor, found their life on the city's outskirts a comfortable one, and in his memoirs Meadows Taylor looked back warmly on the 'jolly days' of hunting and coursing he had spent with his fellow officers in the countryside surrounding Awrangabad. He went on to spend his entire career in Haydarabad State and would later marry the daughter of the banker, William Palmer. Despite the steady grip which the British were able to maintain over the military forces nominally in the service of the Nizām, as the century wore on the kind of strains that would later erupt in northern India in the Great Revolt of $1273 / 1857$ were felt as tremors in the Deccan. In 1243/1827 there was a revolt by the native soldiers of the Contingent against their officers in Muminabad that left the 
British colonel Evans Davies dead and numerous Indian soldiers hung or court marshalled in recompense.

After four decades of the increasing centralization of political and cultural affairs around the Āsaf Jāh court in Haydarabad, by the turn of the nineteenth century Awrangabad had lost almost all its former eminence. Reflecting wider calamities in the Nizām's dominions, its population had been reduced to a fraction of its earlier level, leaving an under-populated township surrounded by the grand ruins of an earlier age. Following his success in the city of Haydarabad, William Palmer established a branch of his banking business in the former palace of Awrangzeb in Awrangabad after the Nizām's finance minister, Chāndū Lāl, handed over control of Awrangabad's revenues to Palmer \& Co. It was only after the intervention of the British Resident Charles Metcalfe that the grip of the company over the finances of the Deccan was released and the 'House of Palmer' (Pāmar kōthì) in Awrangabad was closed in 1236/1820. Yet Awrangabad's vast imperial suburbs continued to sink into decay and after travelling through Awrangabad on his way to the cave temples of Ellora in 1810, the British officer of the Bombay Native Infantry John Seely recorded his impressions of his stay in Awrangabad. ${ }^{9}$ Although the land surrounding the city was fertile, he was surprised to find it deserted and uncultivated. While he admitted that from a distance the city had 'an imposing effect', once within its gates he found it too largely deserted, its 'scanty population' living amid a once grandiose city that was now half in ruin. By the end of the eighteenth century, the Shi' is of Awrangabad had taken advantage of the abandonment of Awrangzeb's vast palace and purchased part of its land for use as a cemetery.

Despite what Seely termed as a general 'air of dejection' that struck him as being unlike the bustle and crowds of other Indian cities, he was still impressed by Awrangabad's streets and buildings and the rich goods that were available in its shops. His observations on the people of Awrangabad are no less insightful, for he claimed that away from the markets the only people he encountered were either grand and finely dressed Muslims or else 'fakeers', that is, religious mendicants (faqìrs) probably connected to one of the Sufi orders. Since there was no British Political Agent in Awrangabad at this time, Seely was forced to fall back upon the hospitality of the Nizām's representative ( $(\bar{\imath} w \bar{w} n$ ) and seek more local means of entertaining himself. Happy to oblige him, the dīwān sent him a hookah, a clay pipe (chilam) and the offer of a nautch, whose dancers apparently impressed Seely most by their modesty, virtue and cleanliness! While clearly enjoying his stay in Awrangabad, and spending time visiting its notable monuments, the city still appeared to Seely as the skeleton of a past empire and 'a memento of princely folly and pride'. Here, in a verbal equivalent of the contemporary orientalist paintings of the Daniel brothers, was the collapse of one empire seen through the romanticizing eyes of the agents of its successor.

Awrangabad's fortunes at this time may be compared with those of the other major Sufi centres in the Deccan. A year after Seely's stay in Awrangabad, George Sydenham, a British officer working for Major Colin Mackenzie's survey of the Deccan, made a visit to the great Sufi pilgrimage centre of Gulbarga in the southern 
Deccan, which had earlier attracted Awrangzeb and Shāh Palangpōsh to its sacred precincts. While he was there, Sydenham compiled a report on the shrine of Gēsū Darāz that is one of the most informative accounts to have survived on the situation of the Deccan's Sufi institutions in the early nineteenth century. ${ }^{10}$ Despite the general antipathy for Mughal ways of his elder brother, Thomas Sydenham, as the British Resident in Haydarabad from 1805 to 1810 , George was much impressed by the architectural and cultural traditions of the Deccan. He was struck by the range of buildings set aside at the Gulbarga shrine for the accommodation of faqiers and by the gleaming whiteness of the shrine's buildings in general, which he attributed to the annual whitewashing that distinguished the mausolea of the Deccan's beloved saints from those of its neglected sultans. Trained to inquire about matters of revenue, Sydenham established that the daily expenses of the 60 attendants (khädims) of the shrine for laying flowers and perfumes and for their own sustenance was 10 rupees per head, adding up to the considerable sum of 600 rupees per day. Sydenham reckoned the income of the shrine to still be substantial, with the sajjäda nashin receiving generous offerings from the 30,000 pilgrims who attended the saint's death anniversary each year, in addition to the income he received from the shrine's lands and a levy of a third of the value of all grain imported to Gulbarga. Unsurprisingly, wealth on this scale meant that the position of sajjäda nashin continued to be an extremely desirable one. Sydenham also recorded some of the extraordinary accounts he was told of the recent attempted murder of the sajjada nashin by the disciples of a rival claimant to the shrine's leadership and another account detailing the exacting revenge taken by the widow of another recent sajjäda nashin that involved a gun battle and an extorted 'offering' (nadhrāna) of some 50,000 rupees. In spite of this unseemly competition and violence, Sydenham still found the status of the saint himself undiminished. 'Musulmans \& Hindoos promiscuously prostrate themselves at his shrine \& he is regarded by all classes as the Saint of the Deckan', he explained; even the Deccan's Hindus invoked the name of Gēsū Darāz before taking their food each evening.

Surviving documents from the early Âsaf Jāh period shrine of Shāh 'Alī Nehrī (d. 1176/1763) in Awrangabad refer to similar disputes surrounding the maintenance of the saint's eponymous water conduit (nehr), whose pool supplied water to the community that inhabited the quarter of the city around the shrine. ${ }^{11}$ When Nasīr al-dīn Nehrī and 'Imād al-dīn Nehrī, sons of the late sajjāda nashīn of the shrine, disputed their respective inheritance in 1226/1811, both parties tried to avoid financial responsibility for repairing the broken conduit. Here, in the decay of the joint infrastructure of shrine and city, we hear an echo of the wider disintegration of Awrangabad described by British visitors of the period.

This disintegration had other ramifications for Awrangabad's cultural and religious life. Such was the flight of learning from the city during the nineteenth century that the Nizām's administration had to invite scores of North Indians (Muslims from Lucknow in particular) to help run the city's administration. Here Awrangabad once again played its part in the promotion of imported North Indian talent over local skills, a process that had long antecedents in the Deccan's history and 
as the so-called mulkì ('local') versus ghayr-mulkī ('immigrant') controversy would prove to be one of the great disputes in Āsaf Jāh Haydarabad throughout the nineteenth century. This influx of Hindustanis was connected to the fact that developments in the main centres of Indo-Muslim cultural life (in Delhi in particular) were to affect a gradual re-assessment of the relative status of the Awrangabad saints in spite of the provincialization of the city itself.

More is known about the religious life of the Deccan during this period through an account of the religious practices of the Indian Muslims compiled for a British administrator by a Deccani Muslim. This text, the famous Qanoon-e-Islam, was composed around 1830 by Ja 'far Sharif ('Jaffur Shurreef'), a former resident of the village of Ellora, located beside Khuldabad. Although the work aimed to discuss the practices of Indian Muslims in general, Ja'far Sharif constantly drew back on his knowledge of Muslim practice in the Deccan. As in Sydenham's account of Gulbarga, the great saint Gēsū Darāz emerges as a seminal culture hero, as does the great 'Abd al-Qādir Jīlānī of Baghdad. ${ }^{12}$ Along with these master saints, Ja'far Sharīf confirms the infiltration of the Sufi saints into almost every sphere of Muslim cultural life in the Deccan, from recreation and festive holy days to cures for illness, forms of social stratification and patterns of bodily adornment and dress. Echoing the importance that the Persian commemorative writers from Kāmgār Khān to Sabzawārī gave to the death anniversaries ('arās) of the Awrangabad saints, Ja'far Shariff describes the charged atmosphere on these occasions that blended reverence with revelry. Muslim divines fraternized with cannabis-intoxicated revellers as music and drumming blended into the sound of prayer, for in a very real way the shrines of the saints were the locations for the Muslim equivalent of the carnivals of Catholic Europe. Yet it was the gay world of Ja'far Sharif, oblivious to the dangers presented by its British observers, that more sober and analytical Sufi scholars like Shāh Walī Allāh (d. 1176/1762) in Delhi and his nineteenth-century heirs were beginning to view as lying behind the malaise of Muslim power in India. ${ }^{13}$ In this critique, which would change the shape of Islam over the next century and a half, lay both a learned condemnation of the ways of the common man and the Muslim formulation of the politics of pleasure.

Yet in the early nineteenth century, prior to the impact of the interwoven discourses of colonialism and Muslim reform, there was still no clear demarcation between popular and learned forms of Islam in the Deccan. The saints venerated by the illiterate retained their position in the written ontological hierarchies of the learned, while their shrines remained the common place of devotion for the elite and the common people. While the old order of the Mughals survived in Delhi, echoed in the Deccan through the continued use of ceremonial Mughal titles at court and on the coinage of the state, the shrines of the saints acted as spaces which were capable of articulating a continuity with the past, echoed in the continued use of the name Mogholai for the region around Awrangabad. The Sufi shrines served as the storehouses of historical memory in which the remembrance of the saint was entwined with the memory of the age in which he lived. Through their architecture, etiquette and legends, the shrines of the saints of Awrangabad were places in which the age of 
Awrangzeb was kept perpetually alive. The architecture of death blended with the commemoration of sainthood and royalty in other ways too, for by this time the great mausoleum of Awrangzeb's wife at Awrangabad was referred to by locals in the same terminology as the shrines of the saints, that is as a dargāh (literally 'royal court'). ${ }^{14}$ In Khuldabad, time had correspondingly softened the imperial image of Awrangzeb into that of a saint. While miniature painters across India were already depicting him piously reading or writing the words of the Quran, around the emperor's simple grave in the shrine of Zayn al-dīn, his piety was expressed in more vividly local colours. When the resident of Awrangbad's cantonment Meadows Taylor visited Khuldabad around 1246/1830, the keepers of Zayn al-dīn's shrine thus described a scene that placed Awrangzeb squarely in the shoes of the Muslim saint. Standing beside the emperor's tomb, Meadows Taylor listened to the attendants 'gravely relate that a tiger of a pious disposition has of late years made his appearance every Friday ... to sweep the pavement before it [the grave] with his tail'. ${ }^{15}$

\section{Shāb Nūrr}

While the lack of local documentation from the period reflects the broader picture of Awrangabad's century of obscurity, it is just possible to trace the broad and changing outlines of the saints among the shadows of the age. Despite the ongoing association of the shrine of Shāh Nūr with representatives of the Āsaf Jāh state through the eighteenth century, during the early part of the nineteenth-century support for the shrine declined, and with the removal of this patronage the cult eventually foundered. While it is uncertain which party disappeared first, during the course of the century the shrine lost the support of both its lineage of sajjäda nashins and its circle of patrons. Without these institutional bulwarks, the status of Shāh Nūr retracted to a shadow of its former self and by the middle of the century the shrine fell into a state of neglect and was effectively abandoned. With the disappearance of the sajjada nashins who had long managed it, the shrine's khanaqah also lost its resident dervishes. Reflecting not only the impoverishment of Awrangabad, this occurred at a time when Sufism in India at large was finding itself with ever fewer sources of material support. The Shi'a Muslim state of Awadh had abandoned the courtly sponsorship of even Shi'a Sufis by the early years of the nineteenth century. ${ }^{16}$ It may have been during this period that the derelict shrine of Shāh Nūr became associated with the Hindu population of several nearby hill villages, a community who came to form a substantial portion of its regular clientele by the twentieth century and to add a more clearly Indic dimension to the saint's identity in subsequent oral tradition. But Shāh Nūr had been associated with Hindu religious figures even in his own lifetime, so it is difficult to attach a reliable chronology to these associations. Whatever the changes in the shrine's clientele through association with a lower status village community during these years, the shrine was nonetheless to remain without the management of a sajjāda nashīn or the patronage of wealthy devotees until the beginning of the twentieth century. 


\section{The saints of Panchakki}

Little is recorded of the history of the shrine during the first half of the nineteenth century. We know that the sajjāda nashīn Shāh Muhammad Sa'īd was succeded after his death by his son, Sa'd Allāh, who was sajjāda nashīn during the opening decades of the nineteenth century. ${ }^{17}$ Sa'd Allāh had two sons and was succeeded after his death by the elder of the two, Amīn Allāh. When he died without issue the lineage continued through Sa'd Allāh's younger son, Hamīd Allāh, who seems to have managed the shrine through the middle years of the nineteenth century. Still governed by this lineage, the shrine's income continued unabated and it remained one of the most important landowners of not only Awrangabad but the Deccan at large.

While the original flow of Central Asian patrons associated with the formation of Mughal and Āsaf Jāh power in the Deccan had all but depleted itself by the early nineteenth century, the shrine's status still enabled it to maintain connections with the governments of the local ruling powers. Persian and Modi documents from the first half of the nineteenth century testify to Panchakkī's continued receipt of lands from representatives of not only the Nizām, but also to the existence of orders from the Maratha Pēshwā for his officers to protect lands belonging to Panchakkī in their districts. ${ }^{18}$ Despite the economic contraction of Awrangabad itself, the shrine's patrimonial links with the Mughalpura quarter of the city (founded as the domicile of Central Asian migrants in the time of Awrangzeb) continued to pay dividends. One surviving document, dated 1239/1823, details the sale of a haveli in the Mughalpura quarter to a local merchant for 220 rupees. The original owner planned to keep a quarter of the proceeds for himself but pass the remainder on to Panchakkī as an offering. ${ }^{19}$ In such surviving documents we glimpse the way in which the shrine remained embedded in the local economy of the city.

Despite the continued recognition of Panchakkī by residents of Awrangabad and the ruling classes of its neighbouring political centres, its saints became increasingly marginalized from wider Naqshbandī tradition. The nineteenth century witnessed an acceleration in the rise of Ahmad Sirhindī's Mujaddidī branch of the Naqshbandī order in India and beyond. This process was to cement the relegation of the Awrangabad Naqshbandīs as a provincial chapter far away from the primary narrative of Naqshbandī history as conceived by its North Indian chroniclers in the nineteenth and twentieth centuries. ${ }^{20}$ Subsequent Naqshbandī lineages and their memorialists bypassed them, for unlike Nizām al-dīn with his famous teacher and son in Delhi, the Awrangabad Naqshbandīs lacked a position in the wider Indian Sufi network through which they could find recognition by the generic Sufi commemorative writers of the nineteenth century. Ultimately, it was only via the small Naqshbandī outpost established by Shāh 'Ināyat Allāh (d. 1117/1705) at Balapur and maintained there by his descendants that Panchakkī would maintain any long-standing link with the wider Naqshbandī world.

Yet Panchakkī continued to be resorted to by locals as a place of pleasure and delight as much as piety. Having earlier been eulogized by Sabzawārī as being 'like a piece of Kashmir in the Deccan', the shrine's gardens, pools and fountains came to 
form the focus of local promenades among the respectable classes of the city's Muslims. In the first half of the nineteenth century, these promenades were witnessed by two separate European visitors, who described the shrine as being well-kept and sparkling with lamps, with the many fountains in the great pool built by the Āsaf Jāh general Jamīl Bēg ever spraying and delightful. ${ }^{21}$ Naturally, the well-dressed local visitors whom early British visitors observed at Panchakkī combined pleasure with piety during their visits by also resorting to the tombs of the saints. Respectable if no longer lordly, these visitors formed a social group that was in some ways not so far removed from that of the original patrons of the saints. This custom of taking evening walks in the gardens of Panchakkī was by no means unique and formed a social function of Sufi shrines elsewhere; a sixteenth-century source records similar public promenades at the shrine of Shaykh Safī al-dīn at Ardabil in Iran. ${ }^{22}$

As we have seen, in his account of the cave temples at Ellora near Khuldabad, the British officer John Seely described Awrangabad as he saw it in $1810 .{ }^{23}$ During his stay in the city, Seely also visited Panchakkī and left an interesting description of the shrine. As with many Indian visitors, it was the shrine's eponymous water mill that immediately caught his attention. Seely, however, was a child of Britain's age of industrialization. Writing about Panchakkī from the genteel comfort of Bournemouth a decade later, he could only look back on the technology of the shrine's water mill (that he claimed attracted more visitors than the tombs themselves) as crude and simple, if 'unique' in India. But this interface between religion and technology at Panchakkī was far from unique and in his account of the Sufis of Sind a few decades later the British orientalist Richard Burton spoke of a local Sufi saint whom he was told loved to sit listening to the sound of water-wheels turning. Other such mills survive in the Hasan Abdal region, through which the saints passed on their journey to the Deccan. Yet despite Seely's faint praise for the water mill at Panchakkī, even he was delighted by the large pool in the outer courtyard, whose shoals of tame fish were fed by visitors and which he was told had been originally put there by the hands of Awrangzeb himself. Echoing Sabzawārì's description of half a century earlier, Seely also recollected the blossom and fruit upon the trees around the shrine as a scene of great beauty. In a mirroring of the human arena pictured by Sabzawārī, Seely also described Panchakkī as being host to a throng of well-dressed Muslim 'priests and doctors', to-ing and fro-ing about the courtyards of the shrine. Within the mausoleum itself, deliberately darkened with oil lamps 'to "make darkness visible"', sandalwood, camphor and myrrh were burned in honour of the saints. ${ }^{24}$ Comparing the number of visitors to the 'dargah' of Awrangzeb's wife Rābi'a Dawrānī, which he had visited earlier, Seely noted that there were more people paying their respects at the tombs of the Panchakki saints. Despite the lure of Rābi'a's extraordinary architectural successor to the Tāj Mahal a short way across the city, and her own quasi-sanctification in mirroring the greatest female saint of Islam in her title of the 'Rābi'a of her age (dawrānì)', the tales of miracles associated with Shāh Musāfir and Shāh Palangpōsh ultimately produced a stronger magnetism than the more plainly imperial piety fostered at the great shrine of the emperor's wife. 
While he was at Panchakkī, Seely was entertained by someone whose name he recalled as Shah Sāfit, a figure who was clearly one of the family descendants of Shāh Mahmūd and possibly the actual sajjäda nashīn of the shrine at this period. The name Sāfit ('benign, liberal') may well have been a nickname for either Shāh Hāfiz Allāh or Shāh Sa'd Allāh, the two sajjāda nashīns of Panchakkī whom Seely was most likely to have encountered. Seely described his host as a cultivated and learned man, and even added that he had visited Europe, including Rome. Given the wealth of the shrine and the mobility of other Indians along the colonial trade routes that had emerged by the early nineteenth century, such a journey seems quite possible. Like similar Muslim Mediterranean journeys of the period, it may have been completed during the course of the pilgrimage to Mecca. Over a century earlier one of the followers of Shāh Musāfir had already travelled as far as Alexandria. This worldly and learned atmosphere fits in with other evidence of the shrine's history at this time. Seely mentioned the number of scholars he encountered there and what we know of the library that developed at Panchakkī confirms this picture of learning. While it is impossible to know precisely what books were present in the library during the nineteenth century, a description of its most valuable assets dating from before its mid-twentieth century dispersal does inform us of a number of early volumes which may have already been present in the first half of the nineteenth century. ${ }^{25}$ One of the most interesting of these works was a manuscript of the famous letters of Ahmad Sirhindī, the Maktūbāt-e-mujaddid-e-alf-e-thān $\overline{\text {, }}$, from the library of the Mughal prince (and briefly emperor) Shams al-dīn Rafi‘ al-Darajāt (r. 1131/1719). As we have seen, Sirhindīs extravagant claims in these letters had caused them to be banned under Awrangzeb, so the presence of a royal copy in the library at Panchakkī is interesting evidence of the circulation of Sirhindī's ideas. Although there was no mention of Sirhind $\overline{1}$ or his followers in the Malfüzāt-e-Naqshbandiyya, the manuscript of the letters shows that the later residents of Panchakkī at least were aware of Sirhindī's writings and ideas. Another specimen from a royal collection was a copy of the Babaristān of the great Timurid poet Jāmī that had originally entered the royal library of Awrangzeb in 1069/1658. This is of considerable interest in view of the association we have seen in the Malfüzāt-e-Naqshbandiyya between the circle of Shāh Musāfir and the literary world of Timurid Herat, not least in Shāh Musāfir's own regular reading of Jāmī's Nafahāt al-uns. Other literary works that may have been present in the library during the period in question include a dīwān of Hāfiz dated to 1223/1808, two years before Seely's visit, and several volumes on epistolary forms (insh $\bar{a}$ '). Unfortunately, the small number of Sufi works noted by the library's later cataloguer - including a malfīzāt of Burhān al-dīn Gharīb of Khuldabad and a treatise by Gēsū Darāz of Gulbarga - bore no dates. Nonetheless, the evidence does suggest the presence of a flourishing library at the shrine during the nineteenth century and probably beforehand as well, a picture that fits in well with the association of Bilgrāmı̄'s learned circle with the shrine in the late-eighteenth century. Compared to the smaller role that textual culture seems to have played in the Sufi pedagogy of Shāh Musāfir and Shāh Palangpōsh themselves, in the course of the century that followed their deaths their shrine became an important local centre of learning. 


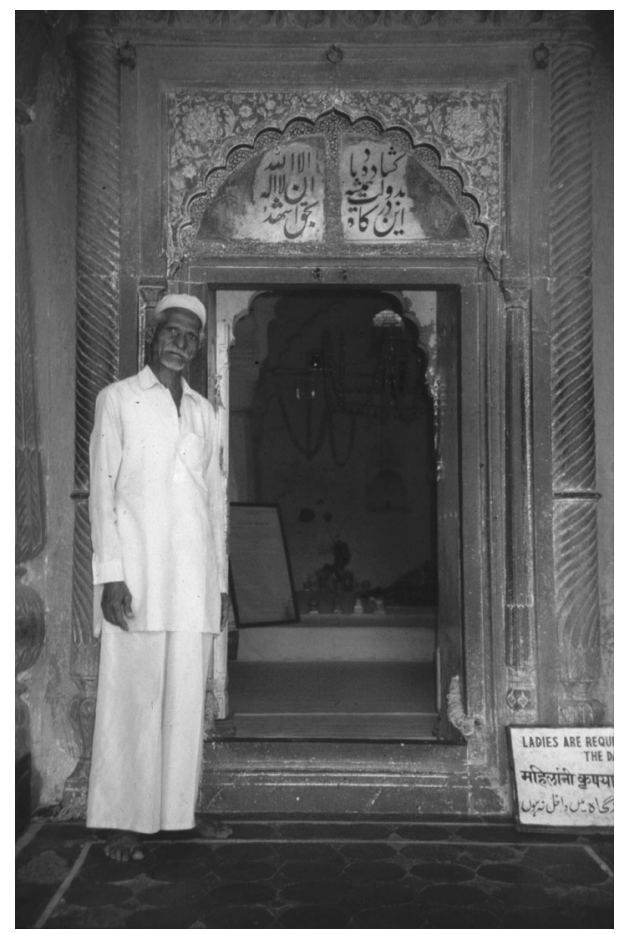

Figure 3.1 Shrine attendant (khādim) before the tomb of Shāh Musāfir.

Aside from this learned role, Panchakkī had also come by this period to act as a vivid architectural reminder of the city's glorious Muslim past. Continuing to reap the financial rewards of the shrine's early endowments, the sajjäda nashinns of Panchakki evidently still received sufficient income from the shrine's landholdings to maintain the costly delights of fountains and festive lighting (chirāghān $\bar{\imath})$ mentioned by visitors. It also seems likely that dervishes continued to reside in its khanaqah at the sajjāda nashīn's expense. Panchakki was thus able to find a role as the epitome of the shrunken city's Mughal past and its more cultivated traditions of Sufi piety.

\section{Nizām al-dīn}

As we have seen, Nizām al-dīn's tradition effectively shifted to Delhi with his son Fakhr al-dīn and his successors during middle of the eighteenth century. In common with what was by this period long-established custom, Fakhr al-dīn was succeeded in Delhi after his death by his son Ghulām Qutb al-dīn (d. 1232/1817) rather than by one of his disciples (murīds). Ghulām Qutb al-dīn continued the legacy of Nizām al-dīn of Awrangabad in Delhi, the city from which the saint had departed for the Deccan over a century earlier. Nizām al-dīn's heirs in this way echoed the bonds we 
have seen tying Nizām al-dīn and the literature surrounding him in Awrangabad to the old capital of Muslim saints and kings in Delhi. Nonetheless, Ghulām Qutb al-dīn's own followers were numerous and through them he was able to maintain the prestige of Nizām al-dīn's lineage among the late Mughal elite of Delhi. Marking his permanent place in Delhi's commemorative tradition, Qutb al-dīn's career was briefly summarized by the great Muslim modernist Sayyid Ahmad Khān (d. 1315/1898) in his celebration of the peoples and places of Delhi, $\bar{A} t h \bar{a} r$ al-sanādìd, which is discussed in more detail later in this chapter. ${ }^{26}$ In Awrangabad, however, the embers of Nizām al-dīn's memory burned less brightly beside the brightness of that of his representatives surrounding the court of the last Mughal rulers in Delhi.

Yet throughout the nineteenth century, the prominence of these North Indian relatives caused a considerable increase in the status of Nizām al-dīn. The circumstances of this rise in the reputation of a saint whose earlier position in the city was by no means one of pre-eminence are of considerable interest, for they show the importance of literary celebration and the possession of trans-regional connections in the saint-making process. Neither Shāh Nūr nor the Awrangabad Naqshbandīs possessed enduring connections with parties in other major cities, owing their fame rather to the purely local connections they were able to make during Awrangabad's years of prominence. As we have seen, when the court left and the city fell into decline, this lack of a wider structure of support in other regions meant that while the saints were by then established as the supernatural patrons of Awrangabad itself, they were unable to find a wider following beyond it. The case of Nizām al-dīn was quite different. It was the same departure of Nizām al-dīn's main successor to Delhi that had contributed to the demise in the fortunes of his shrine in Awrangabad that would in the nineteenth century secure his posthumous reputation. For while virtually no mention of the other saints of Awrangabad seems to have been made during the whole nineteenth century, the name of Nizām al-dīn came to be celebrated in many of the most important North Indian Sufi and other Muslim commemorative works of the age. These included the Takmila-ye-siyar al-awliya of Gul Muhammad Ahmadpūrī (d. 1243/1827) and the Āthār al-sanādz̄d of Sayyid Ahmad Khān (d. 1315/1898).

As a result of this external support, traditions emerged over the following decades that would present Nizām al-dīn as the premier saint of Awrangabad and even argue for a comparable position for him in the Âsaf Jāh state at large. This process of literary celebration combined with the prestige that Nizām al-dīn automatically acquired through his sharing the same spiritual lineage as the older Chishtīs of Delhi and their early descendants at Khuldabad. These factors drew further strength from the memory of Nizām al-dīn's connection with Nizām al-Mulk Āsaf Jāh in order to become the focus of narrative traditions glorifying the saint's command of powers of vast consequence, painting him ultimately as the miraculous founder of the Nizāms' power over Haydarabad. The eventual result was the rise of Nizām al-dīn to the point of eclipsing the prestige of the other saints of Awrangabad. This literary diffusion of Nizām al-dīn's memory stemmed mainly from the influence of Chishtī circles in North India and was the result of Nizām al-dīn's paternal connection with the 
lineage of Fakhr al-dīn in Delhi. After the death of Fakhr al-dīn's son, Ghulām Qutb al-dīn, in 1232/1817 and his burial at the shrine of Bakhtiyār Kākī on the outskirts of Delhi, he was succeeded by his own son, Ghulām Nasīr al-dīn. Better known by the nickname of Kālē Miyān ('the Black Gentleman') in reference to the darkness of his complexion, Ghulām Nasīr al-dīn was part of the religious world of Delhi in the years before the Great Revolt of $1273 / 1857$. All too little is known about either Nasīr al-dīn or the wider practice of Sufism in Delhi during this period, but what is recoverable provides a tantalizing glimpse into the connections of Sufis to the wider cultural life of their surroundings that in its own way reflects what we have seen in Awrangabad.

In the decades before the calamity of the Great Revolt that ended with the British destruction of the whole quarter of Delhi that Ghulām Nasīr al-dīn and his contemporaries had known, Ghulām Nasīr al-dīn was able to drift between the worlds of Sufis, poets and princes. As the scion of what had by then become one of the most learned and respected families in Delhi, several sources mention Ghulām Nasīr al-dīn in the capacity of spiritual master (murshid) of the last of the Mughal emperors, Bahadur Shah (r. 1253/1837-1274/1858). Confirming the emperor's affection for the descendants of Nizām al-dīn, Bahadur Shah's court diary recorded the emperor sending 200 rupees to Ghulām Nasīr al-dīn to defray the expenses incurred at the celebration of Fakhr al-dīn's death anniversary in 1268/1851, as well as sending his close advisor Mahbūb 'Alī Khān to represent him at the ceremony itself. ${ }^{27}$ Ghulām Nasīr al-dīn seems also to have been an acquaintance of the great Indo-Muslim modernist Sayyid Ahmad Khān (d. 1315/1898), who devoted a short section to him in his Āthār al-sanād $\bar{\imath} .{ }^{28}$ At the time of the book's composition around 1263/1846, Sayyid Ahmad described Ghulām Nasīr al-dīn as still being alive and aged around fifty. He was also said to have previously completed the hajj and travelled to Pakpattan in Punjab to be received into the service of the major Sufi (and member of his grandfather's initiatic lineage), Shāh Sulaymān Tawnsawī (d. 1267/1851), before returning to settle in Delhi. But as far as Sayyid Ahmad was concerned, by the 1260s/1840s Ghulām Nasīr al-dīn was being followed by all of the notables (umarāa of Delhi in his own right, as well as by the emperor himself. This description was drawn upon by Thomas Beale, the nineteenth century British compiler of the Oriental Biographical Dictionary, for whom Ghulām Nasīr al-dīn was also the spiritual guide of the emperor, but who in spite of his elevated status 'preferred the habit of a dervish'. ${ }^{29}$

Ghulām Nasīr al-dīn was also a close friend of the great Urdu and Persian poet Mīrzā Ghālib (d. 1285/1869), whose verse poignantly reworked the tropes and terminology of the Sufis in an age in which the old Indo-Muslim world was so clearly falling apart. According to Ghālib's student and biographer, Altāf Husayn Hālī (d. 1914), Ghulām Nasīr al-dīn sought to help and promote Ghālib as best he could. In return, Ghālib rewarded the Sufi with the pleasure of his company and the sharpness of his wit. Hālī recounted how when Ghālib was released from Delhi's British-administered prison after serving a sentence for gambling in 1264/1847, he went to stay at the house of Ghulām Nasīr al-dīn. While he was there someone came 
by to congratulate the poet on his release from gaol, to which he replied with a play on his host's nickname of Kālē Miyān: 'What idiot has come out of prison? First I was the prisoner of the white man ( $g \bar{u} r \bar{e} k \bar{\imath}$ qayd), and now I am the prisoner of the black man (kāle kì qayd). ${ }^{30}$

Such jokes aside, Ghālib’s relationship with Nasīr al-dīn was closer than his barbed wit might suggest. Ghālib's letters reveal the warmth of their friendship no less than the poet's indebtedness to the Sufi, as well as the ways in which their destinies were intertwined during the last years of Mughal Delhi. Ghālib seems to have lived rent free in one of Nasīr al-dīn's houses for between 3 and 5 years, while in the period after Ghālib's release from prison Ghulām Nasīr al-dīn's close connections with the emperor were responsible for gaining Ghālib the audience at court he so much required. ${ }^{31}$ In one of his letters from this period, Ghālib praised his friend Nasīr aldīn in glittering terms that reflect the nature of Ghulām Nasīr al-dīn's favours, writing that since he was Nasīr al-dinn's neighbour, by sitting in the dust of the latter's threshold even the angels came to envy him. ${ }^{32}$ But with the Great Revolt of $1273 / 1857$, much of the world that Ghālib shared with Nizām al-dīn's greatgrandson in Delhi was to disappear forever. While some sources claim that Nasīr aldīn died a few years before the Revolt in 1268/1852, as we see in the Chapter 4, this date was disputed by Ghālib himself.

For Nizām al-dīn of Awrangabad, being connected so closely with the last major Sufi circle of Mughal Delhi meant that his name was plucked from the provincial obscurity that enveloped his contemporaries. The ongoing fame of his descendants in Delhi meant that he was commemorated by a series of Muslim writers anxious to shore up the heritage of Islam in the face of its political, economic and cultural disenfranchisement with the coming of British rule. But Fakhr al-dīn's position in Delhi was also profitable to Nizām al-dīn's legacy in other ways. Muhammad Sulaymān (d. 1267/1851), a disciple of Fakhr al-dīn's own student, Nūr Muhammad Mahārawī (d. 1205/1791), later achieved considerable fame in his own right. In time Muhammad Sulaymān's son and successor, Khwāja Allāh Bakhsh (d. 1319/1901), developed his father's shrine and its surrounding village near the Salt Range in Punjab into an important centre of Sufi learning. ${ }^{33}$ As in the case of other IndoMuslim religious circles during this period, the ever-increasing encroachment of British colonial influence over matters of life and thought previously contained within the domain of Islamic praxis and theory encouraged the development of new religious institutions capable of either addressing or avoiding the perceived threat of colonial influence. At Muhammad Sulaymān's 'House of Learning' (dār al-'ulūm) in Tawnsa, as at so many other emerging Sufi teaching institutions across North India at the same time, Sufism was being reigned in to stand within the clear confines of an Islamic religiosity as conceived through the textual and scholarly lenses of $\operatorname{shari}^{-} a$ and hadith scholarship. During the first half of the nineteenth century, these developments - still only indistinct almost anywhere at this time - would have little effect on Awrangabad, sheltered under the relative protection of the theoretically independent Nizāms of Haydarabad. But as we see in Chapter 4, for all of Awrangabad's independence from British India, the years that followed the Great Revolt saw the 
shadows of British power creep slowly across India to colour the destiny of its Sufis as well.

\section{The literary tradition}

\section{When Delbi remembered the Deccan}

Despite the local success of his cult, Shāh Nūr remained very much part of a tradition of local saints, celebrated in Awrangabad but scarcely known elsewhere. For their part, the Awrangabad Naqshbandīs were similarly able only to maintain a restricted local following (in large part through the splendour of their shrine), but lacked the connections beyond the city to spread their fame elsewhere. Of all of the Awrangabad saints, it was the memory of Nizām al-dīn that underwent the widest textual proliferation in the centuries after his death and whose name came to feature in commemorative writings composed right across India. However, the only significant Sufi work from the Deccan in which Nizām al-dīn featured during this period was the early nineteenth-century Mishkat al-nubuwwat of the Haydarabadi Sufi, Ghulām 'Alī Qādirī. ${ }^{34}$ This vast biographical compendium sought to collate material on all of the Sufis from the beginning of Islam to its author's own lifetime. Of course, the criteria for inclusion were shaped by the author's own historical and regional context, and the work contains a firmly Indocentric leaning. The short biography of Nizām al-dīn appears amid those of his contemporaries, including figures of merely local importance like the Haydarabadi ecstatic (majdhūb) Bādshāh Sāhib. The closer the work reached to its author's own period the more it featured local figures whose status was magnified to reflect that of the grand pan-Islamic figures featured in the earlier volumes of the work; in such ways a trans-regional past served to dignify a local present. The notice on Nizām al-dīn repeats what were by now the conventional details of his initiation in Delhi and move to Awrangabad at his master's command, along with an account of Nizām al-Mulk's devotion to him. Indeed, the greater part of the notice on the saint consists of a résumé of the career of Nizām al-Mulk and a version of an important legend of the saint's miraculous aid to Nizām al-Mulk that was by this period finding written form. The author's description of this tale as a being a 'famous story' (qisa-e-mashhür) shows that it was already well known before it came to be written down. The account concerned the battle that Nizām al-Mulk fought with his rival Mubāriz Khān for control of the Deccan in 1137/1724, and centred on the rival's possession of a saintly relic of a tattered cloak ( $g u d r \bar{\imath})$ given to him by another Sufi called Shāh Dawla. But it is faith in the saint that is the central moral of this tale of the saint and the king. For despite delaying battle out of fear, once Nizām al-Mulk put his trust in Nizām al-dīn he immediately won a decisive victory and so it was that control of the Deccan fell into his hands.

However, it was in the literary circles of Delhi that Nizām al-dīn's memory was passed on most effectively. We have seen his teachings being kept alive in the decades following his death through the transfer of his lineage to Delhi with his son Fakhr al-dīn. Until the aftermath of the Great Revolt of $1273 / 1857$, this tradition would 
persist in spheres of the highest influence in Delhi. Although Nizām al-dīn's tradition continued in Awrangabad under the guidance of the sajjäda nashinns at his shrine - still described as a place of pilgrimage in the nineteenth century in the Mishkat al-nubuwwat - it was nonetheless the flourishing of the main branch of his lineage in Delhi that secured his posthumous reputation in the years following Awrangabad's eclipse. Narratives concerning the life of Nizām al-dīn thus featured in numerous texts composed in northern India during the eighteenth century, such as the Fakbr al-tālibīn and Manāqib-e-fakbriyya of 'Imād al-Mulk Fīrōz Jang III (d. 1215/1800), which were mainly concerned with Fakhr al-dīn. Nizām al-dīn also featured in many of the great Chishtī tadhkirāt composed during the nineteenth century, the most important of which was the Persian Takmila-ye-siyar al-awliy $\bar{a}$ of Gul Muhammad Ahmadpūrī (d. 1243/1827). What is of interest about this series of texts is their clear geographical bias, emphasizing Nizām al-dīn's connections with a Delhi-centred tradition rather than a tradition with any firm links to the Deccan.

In the series of works written in Delhi by the supporters of Fakhr al-dīn, Nizām al-dinn was presented as the pre-eminent figure in the religious life of the Muslim Deccan. A section of the Manāqib-e-fakbriyya (1201/1787) of Fakhr al-dīn's courtly follower 'Imād al-Mulk (the erstwhile vizier of the emperor in Delhi) was devoted to the acclamation of Fakhr al-dīn's father Nizām al-dīn. ${ }^{35}$ In the Manāqib-e-fakbriyya, 'Imād al-Mulk emphasized the fact that his own ancestor Nizām al-Mulk had taken a Sufi initiation (bay'at) at the saint's hands. ${ }^{36}$ Although writing from Delhi, 'Imād al-Mulk gives some information on the state of affairs in Awrangabad, mentioning that the death anniversary of Nizām al-dīn was still being celebrated there and that the saint's son Fakhr al-dinn had many followers who were resident in Delhi. ${ }^{37}$ If this information is correct, it suggests that the spiritual connections Awrangabad forged with Delhi during its period of Mughal rule were retained after the re-emergence of the Deccan's independence under the Āsaf Jāh rulers.

Nizām al-dīn also featured in the lengthy mathnaw̄ poem 'Imād al-Mulk wrote in praise of Fakhr al-dīn entitled Fakbriyyat al-nizām. In the poem, 'Imād al-Mulk described the coming of Nizām al-dīn to the Deccan and his settling there to teach the 'people of Āsaf Jāh'. ${ }^{38}$ Nizām al-dīn was presented as a great teacher and as having secured the devotion of Nizām al-Mulk, who was once again said to have received a Sufi initiation from Nizām al-dīn. Later 'Imād al-Mulk explained in poetic language how upon hearing of Nizām al-dīn's death, Nizām al-Mulk rushed in grief to his khanaqah in Awrangabad to give his sympathies (tastīma). ${ }^{39}$ After much crying and sharing of condolences, as we saw in Chapter 1 Nizām al-Mulk asked Fakhr aldīn to succeed his father and the other shaykhs of Nizām al-dīn who were present agreed. Even though Fakhr al-dīn did not want to accept, wishing instead to defer to his older brother, he underwent the ritual of succession by having the turban wrapped around his head and being placed on the 'cushion of rightful guidance' (masnad-e$i r s h \bar{a} d$ ). What is fascinating about this account is the way in which it ties the destiny of the families of Nizām al-Mulk and Nizām al-dīn together. For in 'Imād al-Mulk's verses we in fact read how the author's own grandfather Nizām al-Mulk was responsible for elevating Fakhr al-dīn into the position of official successor to Nizām al-dīn. 
While composing a poem in praise of the deeds of his spiritual master Fakhr al-dīn, 'Imād al-Mulk thereby reminded his readers that his own family were in some way responsible for the fortunes of Fakhr al-dīn. For if Nizām al-Mulk is shown as a devotee of Nizām al-dīn, in being presented as having the authority to appoint Fakhr al-dīn as his successor, the older prince asserts his authority over the young Sufi. Here is a reflection of the description of Diyānat Khān appointing the early sajjāda nashīns of Shāh Nūr and of Mansārām's account of Nizām al-Mulk appointing a sajjāda nashīn for the shrine of Qādir Awliyā (d. 1098/1687) in Awrangabad. ${ }^{40}$ 'Imād al-Mulk thus ensured that the memory of Nizām al-dīn's relationship with Nizām al-Mulk would be passed on through time. It was through such textual webs as those woven in Fakbriyyat al-nizam that the ties that bound the families of Sufis to those of their patrons could be woven into the future no less than the past.

It is interesting to compare 'Imād al-Mulk's account of Nizām al-dīn with that of the prominent North Indian Sufi, Gul Muhammad Ahmadpūrī (d. 1243/1827), who was active in founding Sufi teaching institutions in Punjab. Gul Muhammad was a follower of the Punjabi Chishtī, Muhammad 'Āqil (d. 1229/1814), who was a disciple of Fakhr al-dīn's follower Nūr Muhammad Mahārawī (d. 1205/1791) and of Fakhr al-dīn himself. Like his disciple, Muhammad 'Āqil also established Sufi foundations in Punjab in which logic and jurisprudence were taught alongside mysticism (tasawwuf). As in the evolution of similar institutions elsewhere in northern India during this period that were tying Sufi teachings into the firm boundaries of legal and traditionist scholarship, the image presented of Nizām al-dīn and Gul Muhammad's other predecessors must be seen in the context of the creation of the kind of etiology and routinized charisma that such religious institutions demanded. The foundation of an institution in this way formed an important part of the survival of memory upon which sainthood depends. Like 'Imād al-Mulk, Gul Muhammad was also an interested party in the history he was writing, for his own spiritual credibility in some sense stood on the shoulders of each of his predecessors. And as a follower of Muhammad 'Āqil, Gul Muhammad's predecessors perforce included both Fakhr al-dīn and Nizām al-dīn of Awrangabad.

Gul Muhammad's account of Nizām al-dīn is found in his Takmila-ye-siyar alawliy $\bar{a}$, his completion (takmila) of the classic Chishtī hagiography Siyar al-awliy $\bar{a}$ of the early Sufi writer Mīr Khwurd (d. 770/1368), whose own life was spent between Delhi and the Deccan. In his text, Gul Muhammad sought to link his own chain of teachers (and so by extension himself) with such great Chishtī saints of medieval Delhi as Nizām al-dīn Awliyā (d. 725/1325) by linking himself and his teachers to them in a continuous chain of initiation and narrative. ${ }^{41}$ The notices that Gul Muhammad wrote on the section of the chain stretching between Nizām al-dīn Awrangābādī and his own master Muhammad 'Āqil were far better informed than the rather hazy links connecting Nizām al-dīn with the great Sufis of Delhi from Nasīr al-dīn Chirāgh-e-Dihlī (d. 757/1356) onward. Such an initiatic chain (silsila) did in some sense exist, but the reality which hagiographic texts like that of Gul Muhammad disguised was that what they recounted were in fact only one of many chains of succession that could claim these connections. Writing was therefore 
a means of publicizing and promoting the claims of one of these chains over others. Or at least it was when coupled with the necessary counterpart of a readership capable of acknowledging its assertions.

Like other such texts, Gul Muhammad's Takmila shows the way in which writers of Sufi commemorative texts drew on the writings of earlier Sufi memorialists no less than other writers involved in historiographical enterprises. As such, in his account of Nizām al-dīn, Gul Muhammad cited Kāmgār Khān's malfīzāt, Nizām al-dīn’s own Nizām al-qulūb and the collection of letters sent to Nizām al-dīn by Shāh Kalīm Allāh. He also supplemented these works with information drawing on oral tradition and, possibly, other unnamed written sources. What is interesting about Gul Muhammad's use of written sources, however, is the editing and shaping process which he undertook in selecting what information to take from them for his own account of Nizām al-dīn. Unsurprisingly, the selection of this nineteenth-century Indian scholar differed from that of the modern day European scholar: Gul Muhammad makes no reference to the friendships with Yogis or the squabbles with students that we have described in the present work. By contrast, Gul Muhammad's purpose was to provide a biographical account of Nizām al-dīn which, though attempting to be historically accurate, nonetheless brought to the fore those qualities of the Sufi which might be most worth emulating. In this respect, we must again bear in mind the institutional context in which Gul Muhammad's account was written and his likely imagined readership among his own students and disciples. It is partly as a result of the institutional contexts in which such texts were written and intended to be read that their contents vary significantly from the more colourful accounts which sometimes occur in tadbkirāt composed by writers (like 'Urūj) who were positioned outside this pious tradition and whose works were intended for a wider readership than solely aspirant professional men of the faith. It is therefore hardly surprising that Gul Muhammad emphasized Nizām al-dīn's dedication to the upholding of the religious law (shari $\bar{i}^{\prime} a$ ) and to the pious etiquette (adab) that won the saint the respect of all who knew him.

These complementary attributes are of great importance with regard to both the teaching institutions overseen by the likes of Gul Muhammad and the overall character of Muslim social life in India in which Sufism played so large a part. For what Nizām al-dīn embodied here was the importance of self-discipline, the constant will towards shaping one's character and behaviour towards compliance with an ideal ultimately embodied in the custom (sunna) of the Prophet Muhammad. In many ways, this deliberate re-shaping of both the private and the public self formed the greater part of the guidelines laid out by the study of Sufism and Islamic law respectively. It is in this sense that we should understand the madrasa institutions such as those governed by Gul Muhammad and his Indian contemporaries as places in which learning was not merely a phenomenon of the intellect, but a means of shaping the whole being. An important part of this self-fashioning was the disciplining of the body, a discipline which was not to be carried to ascetic excess but to be exercised within the more moderate limits prescribed by centuries of Sufi and other Muslim moralizing works. The complementary aspect to this outward discipline was the 
purification of the inner self. This was precisely the function of the Sufi meditational techniques described by Nizām al-dīn in his Nizām al-qulūb, and whose importance was further emphasized by Gul Muhammad. The ideal product of these institutions was therefore a particular kind of man, not primarily learned but transformed. Ready to return to the wider community, such a man could act as an example before others, as Nizām al-dīn had before those who knew him.

In Gul Muhammad's account of Nizām al-dīn we find that the edifying figure of Nizām al-dīn was himself devoted to the imitation of the behaviour of the Prophet Muhammad. It is in this sense that works such as the Takmila must be seen as textual aids to this process of self-transformation. Here was the conjunction of a much older Sufi tradition of self-discipline with an emergent current of Muslim piety during the nineteenth century, giving renewed emphasis to the imitation of the Prophet as the basis for all Muslim religious life. At this point in Indo-Muslim history, however, it was the Sufi saint who was still seen as best able to embody the Prophet's own qualities.

Nonetheless, it is important that we do not miss the changes that were occurring within the tradition of Sufi biographical writing at this time. For no less than Gul Muhammad's Takmila, Kāmgār Khān's Absan al-shamā'il on Nizām al-dīn also sought to present the saint as a model for pious emulation, as made clear in its title's invocation of the saint's 'beautiful characteristics'. Both texts placed considerable emphasis on the institutional character of Sufi life, Absan al-shama'il in its literary use of the khanaqah as the setting for the episodes it describes and the Takmila in its emphasis on Nizām al-dīn's institutional links to his master Kalīm Allāh's and his own khanaqah. In neither text do we see the Sufi aside from his proper institutional milieu, which is only appropriate given the important role of the institution in the spiritual task at hand of the shaping of the self. The milieu is therefore constitutive of the man. But despite these similarities, Gul Muhammad's version of the Sufi man is a more narrowly defined one than that presented by Kāmgār Khān or even that glimpsed in the sermonizing letters sent to Nizām al-dīn by Kalīm Allāh. Although many omissions must be forgiven in an account barely reaching twenty manuscript pages in length, a selective narrowing of focus is still apparent. Gone are the (admittedly few) accounts of miracles attributed to Nizām al-dīn, while any mention of his association with Yogis is effaced in favour of the exclusively Muslim company he kept with his learned master and students. Similarly absent are Kāmgār Khān's accounts of Nizām al-dīn's pilgrimages to the shrines of other saints, though, in reflection of the legitimacy which music managed to maintain among the Chishtiyya, Kāmgār Khān's emphasis on the importance that Nizām al-dīn gave to the musical performance (majlis-e-sama $\bar{a}^{\prime}$ ) is echoed in the Takmila ${ }^{42}$ Overall, the predominant tone of Gul Muhammad's text remains one that was guided by the experience of institutional life and aimed at promoting the behavioural codes maintained by madrasa-khanaqahs like those founded by Gul Muhammad himself. Nizām al-dīn is thus seen always sharing his food, insisting on quiet during meetings (majälis), equally dividing the gifts (nadhr) he is offered or spending the hours between prayers quietly reading the Quran or other books in his room. ${ }^{43}$ We have earlier seen the 
saints and the stories told about them serving a variety of social and political functions: here we see the saint promoted as the model student. Yet this should be seen not so much as a demotion in status. Rather, it is a reminder of the important role that the doctrines and discipline of Sufism have played in Muslim societies in the promotion of ethical and behavioural codes aimed at the creation of a humane public sphere.

As the generic title of the tadbkira suggests, memory plays a fundamental part in the raison d'être of this genre of writings. The memory of the deeds of past notables of the community was valued in its own right, even if this did not mean that historical memory was free from the ideological uses inherent in any historical discourse. Like 'Imād al-Mulk in his Fakbriyyat al-nizām, Gul Muhammad made reference to the association between Nizām al-dīn and Nizām al-Mulk, also claiming that the ruler of the Deccan undertook an initiation (bay'at) at Nizām al-dīn's hands and became his disciple. ${ }^{44}$ Unlike 'Imād al-Mulk, however, Gul Muhammad had no immediate family connection with Nizām al-Mulk and the repeating of the tradition of the connection between the ruler and the saint seems rather to fit in with the long hagiographical tradition of aggrandizing the reputation of saints by associating them in one way or another with sultans. We have already had cause to mention the traditional links - whether actual or narrative - between the Muslim saints and kings of precolonial India and in this respect Gul Muhammad forms an important link in the chain with the next commemorator of Nizām al-dīn, Sir Sayyid Ahmad Khān (d. 1315/1898). Writing in early nineteenth-century Punjab, Gul Muhammad still inhabited a region that would not be subjected to British power until 1265/1849, though the decline of Mughal power and the rise of the Sikhs meant that Muslim political power was nonetheless clearly threatened there. The regional ambit of much of Gul Muhammad's activity fell within the territories of the small Muslim successor state of Bahawalpur, which did not enter into a treaty with the East India Company until 1248/1833, some six years after Gul Muhammad's death. In the Takmila, this precolonial Indo-Muslim world was perhaps echoed in the remembrance by Gul Muhammad, whose teaching institutions were safeguarded by the existence of Bahawalpur state, of the association of his Sufi predecessor Nizām al-dīn with the ruler of a similar Muslim successor state over a century earlier.

Unlike Gul Muhammad, Sayyid Ahmad Khān wrote his short account of Nizām al-dīn in a city that was already under British control. His account of Nizām al-dīn is found in his Urdu $\bar{A} t h \bar{a} r$ al-sanādìd (c.1263/1846), the classic nineteenth-century encyclopaedia of the disappearing architectural splendours of Muslim Delhi written largely in response to the rise of British power. ${ }^{45}$ In contrast to the account of Nizām al-dīn in Gul Muhammad's Takmila, the account of the saint in the Āthār al-sanādìd was more concerned with the upholding of the prestige of an urban tradition than a more specifically Sufi one. While it was a predominantly Muslim Delhi that Sayyid Ahmad Khān described, his text thus belonged more to the tradition of urban panegyrics discussed earlier than to the tradition of strictly Sufi biography embodied by Gul Muhammad's work. Here the memory of the saints associated with Delhi, like Nizām al-dīn, was evoked to service the memory of a sophisticated urban society rather than 
to shape the morals of a discretely religious community of scholars and students. An important consequence of this was that the $\bar{A} t h \bar{a} r$ al-sanādìd upheld the claims in Nizām al-dīn's commemorative tradition that associated him with Delhi rather than Awrangabad. In this way, over two centuries after Nizām al-dīn left the city of his early studies its claims to his memory were being championed over those of Awrangabad in one of the key Urdu texts of the nineteenth century. Due to the fame achieved in Delhi by Fakhr al-dīn and his successors in Delhi, Nizām al-dīn's own biography in this text was pared down to a series of intertwined spiritual and familial relationships: descended from Shihāb al-dīn Suhrawardī, married into the family of Gēsū Darāz, taught by Kalīm Allāh and in turn the father and teacher of Fakhr aldinn. By this point, almost every trace of the personal identity of the living Sufi had been sacrificed to the very commemorative structures by which the textual tradition continued to uphold Nizām al-dīn's name. The image of the living dervish was now fully eclipsed by the structures of saintly hierarchy and descent that served to delineate spiritual authority and channel the power of blessing.

The fame and spiritual power of Nizām al-dīn was no longer being used to bring prestige to Awrangabad, nor to confirm the status of its shrines, as in the Sawanih of Sabzawārī. Instead, as part of Sayyid Ahmad's aim of celebrating the Muslim architecture of memory, Nizām al-dīn's name was evoked only to add to the prestige of Delhi. Recent appraisals of Nizām al-dīn picturing him as the driving force behind a Chishtī revival have therefore perhaps overestimated the role of individual activity in this process. ${ }^{46}$ For sainthood and the cultural memory that sustains it are ongoing processes, requiring constant maintenance over time. Whatever Nizām al-dīn's own writings and efforts, his continuing posthumous fame could only be won for him by the ongoing success of his descendants. 


\title{
SAINTS, REBELS AND REVIVALISTS
}

\begin{abstract}
What a heart-opening, wonderful and peaceful place! Surrounding the lodge (takiyya) is a pleasant compound of many corridors. There are several cells (bujrahā) and hermitages (sawāma), and in each one of them there live faqirs, amirs, travelers and the tailors of cloaks. ${ }^{1}$
\end{abstract}

\section{From revolt to revival}

The Great Revolt of 1274/1857 that ended with the final dissolution of the Mughal dynasty is often regarded as a largely North Indian affair. Yet despite the alliance between the British and the Nizām in Haydarabad, the Deccan witnessed disturbances of its own and later felt the aftershock of the calamities in the north in a number of ways. Despite the independence of Haydarabad State from direct British rule, the guiding colonial hand of the Resident in Haydarabad played a central role in the politics of the region. This was underpinned by the presence of a British Resident in Haydarabad and the Contingent forces paid for by the Nizām but commanded by British officers. ${ }^{2}$ Contingent soldiers had arrived in Awrangabad in the first decades of the nineteenth century and by mid-century the presence of their cantonment a mile to the west of the old city of Awrangzeb and Nizām al-Mulk was an established part of Awrangabad's urban geography. But while the officers of the Contingent were British, the soldiers were composed not only of residents of the Deccan but also of large numbers of North Indians from Awadh, whose presence was the cause of much anxiety among their British officers as the events of 1857 unfolded. By the mid-nineteenth century, Haydarabad State already had a history of military rebellions in its own right. Amid the competition for privilege and resources among the different social and ethnic groups who made up the state's population, the nineteenth century saw a reassertion of the old pattern of rivalry between local (mulkî) and immigrant (ghayr-mulk $\bar{\imath}$ ) communities that had been a theme in the Deccan's history since the time of the Bahmani sultanate. This was particularly the case with regard to competition for political influence at court and its humbler counterpart of employment in the administration or armed forces in the provincial towns of the state. While commerce remained largely in the hands of powerful Hindu trading castes, throughout the history of the Āsaf Jāh state the bureaucracy remained the 
favoured (though by no means exclusive) domain of Muslims. The overall proportion of Muslims was small compared to the Hindu population, hovering around 10 per cent from the period of the earliest census in 1881 onwards. But the Muslims represented an important landholding class that, through endowment (waqf) arrangements, also included the sajjäda nashins of many of the region's Sufi saints. As we have seen in Mughal Awrangabad, the attraction of material reward brought members of many different Muslim communities south to the Deccan and with the gradual fall of India's Muslim states into British hands, the Āsaf Jāh Deccan continued to attract migrants throughout the nineteenth century. Mainly from North India, but also from the Hadramawt, Afghanistan and Iran, these new migrants continued to enrich the Deccan's complex and multi-layered Islamic tradition.

Among these many communities, for both the rulers and the citizens of Haydarabad the most wearisome were the Arab soldiering families who had long formed an important part of the Nizām's armies. While Arab immigration continued for much of the nineteenth century, both the rearrangement of Haydarabad's armed forces under British supervision and the more general bankruptcy of the state meant that the Arab contingents became either redundant or badly in arrears of pay. As a consequence, marauding gangs of Arab and to a lesser extent Afghan soldiers became a common feature of the Deccan countryside, while their intermittent riots became no less a threat to urban life. Arab mercenaries formerly in the service of smaller native states further contributed to the problem. During the second half of the nineteenth century, the fiscal and administrative reforms of the Nizām's prime minister Sālār Jang (d. 1300/1883) gradually brought a solution to the Arab problem, but in the middle decades of the century they remained a serious threat to social order. In 1269/1853 there was a serious disturbance in Awrangabad caused by Arab soldiers nominally in the service of the Raja of Dawalgawm, which was only suppressed by the intervention of the Contingent troops stationed in the city's cantonment. ${ }^{3}$ Two years later, a similar incident occurred in nearby Jalna, when around three hundred Rohila Afghans, who had been plundering the countryside, were pursued into Jalna by soldiers of the Contingent. There they tried to claim sanctuary in the Sufi shrine of Nūr Shāh Walī, but were nonetheless attacked and ultimately forced to surrender after a gun battle that resulted in almost a hundred fatalities. ${ }^{4}$

In many ways, the Great Revolt was the culmination of the disruption caused by the changing social order in India in which the threat to old authorities and loyalties reached a decisive point. But if Haydarabad ultimately emerged from the 'Mutiny' with the Nizām confirmed in British eyes as 'our faithful ally', at the time the sepoys' revolt in North India was seen as a cause for considerable alarm by the Resident in Haydarabad and the officers of the Contingent. Haydarabad witnessed a surreptitious poster campaign decrying British influence. Anti-British sentiments culminated in an attempted storming of the Residency by supporters of the North Indian rebels after Rohila Afghans had gathered in the city's famous Mecca Mosque to hear sermons preaching rebellion. In Awrangabad itself, the bazaars were rife with rumours of an uprising on the scale of the north that would massacre all of the British Residents of the cantonment. Some of the wives of the British officers were forced to 
escape to Ahmadnagar in British territory, disguised as local Muslim women observing purdah. ${ }^{5}$ Convinced that the cantonment was due to be stormed by its own cavalrymen, in the summer of $1274 / 1857$ Awrangabad's British officers attempted to quickly arrange for the cantonment's defence and fighting soon broke out between rebellious cavalry forces and the loyal infantrymen posted to guard the British enclave. The uprising quickly dissolved due to the arrival of reinforcements from Poona and the rebels escaped into the hills surrounding the city. Twenty-four men were later captured and executed as the ringleaders. The swiftness and violence with which Awrangabad's uprising was suppressed meant that there were no further violent reverberations of the events in North India.

The years after the uprising saw the British further strengthening their presence in Haydarabad State. As in other princely states, a de facto military presence in the state gradually assumed other dimensions of control as Haydarabad's administration was rapidly modernized in the wake of Sālār Jang's reforms. The year 1301/1884 saw the establishment of the office of the Inspector General of Police, whose duties from the state capital included the administration of policing in the state's second city of Awrangabad. ${ }^{6}$ From its establishment, this office was filled by a series of British officers - Inspectors Ludlow, Hankin and Gayer - before an Indian Muslim first assumed the post four decades later. Nonetheless, for much of its early history Haydarabad's police force had a more intimate connection with the Deccan's religious heritage. With no proper buildings of their own, local police forces made makeshift stations in the region's Shi'i 'ashürkhānas, which were only used during the mourning ceremonies of Muharram when the police would be annually turned out of their stations. ${ }^{7}$ While the central administration of Muslim religious activities remained in the hands of local representatives - largely Haydarabadi Muslim notables - religious matters also at times fell into the purview of police control, not least as communal violence began to spread through the state in the early twentieth century. The fixing of the times and routes of both Hindu and Muslim religious processions became a police matter, bringing the symbolic claiming of public space under police control in the name of public order. These regulations were to have a direct effect on the shrines of the saints, whose annual death anniversaries had always been accompanied by the often raucous processions $(j \bar{a} \bar{u} s)$ that carried jars of sandalwood paste to be rubbed into the saint's tomb to the accompaniment of great merriment. In the wake of what the British saw as the religious roots of the Great Revolt, Haydarabad's police were also expected to be on the alert for anti-British movements disguising themselves in religious garb. Over time these obsessions would focus on the presence of militant 'Wahabee' Muslim propagandists in the state, resulting in a series of high profile trials.

Awrangabad's Hindus came under suspicion of affiliation to the anti-British propagandizing of Maratha nationalists like Bal Gangadhar Tilak (1856-1920) in the neighbouring Bombay Presidency. While never part of British India, many of the people of Haydarabad State were sympathetic and indeed instrumental in the wider Indian movement towards self-rule. Given Awrangabad's location in the Marathispeaking region of Marathwada and its proximity to the emerging centres of Maratha nationalism in the Bombay Presidency, the tone of political agitation in Awrangabad 
shared much in common with the emerging Maratha nationalist movement. With the overwhelming Hindu majority in Haydarabad State and the fact that the state during this period offered more opportunities in the civil service (if not in commerce or other areas) to Muslims, it was unsurprising that Hindu revivalist movements intersected with cries for political independence as elsewhere. By the beginning of the twentieth century, the British presence in Awrangabad was subsequently more visible and influential than ever and as such was enough to provoke a variety of anticolonial reactions from the city's residents in spite of the close official relationship between Haydarabad and the British. Some of these relations were amicable, like that between the English novelist E.M. Forster and his 'dashing' host during his stay in Awrangabad in 1913, the young civil servant Abū Sa 'īd Mīrzā. ${ }^{8}$ Together they spent several days wandering around Awrangabad's monuments, musing on the past glories of Muslim India.

The British community in Awrangabad expanded the cantonment area which had initially developed around the Contingent barracks and the years after the Nizām's decisive show of loyalty also saw the construction of two churches in Awrangabad. The first of these, Holy Trinity, was built as a garrison church in typical neo-gothic style in 1863, with a bell tower and a large surrounding compound. Known locally as the English church, Holy Trinity was chiefly used by the families of the British officers serving in the Contingent and any other Britons (later including missionaries) who were also resident in the cantonment. As in so many of India's colonial churches, plaques on the walls commemorated the lives of the officers of the settlement, such as Captain Ogilvy, the Nizām's Polo Commissioner. The church had a series of British chaplains over the years of its foundation, including a number of chaplains provided by the Church Missionary Society. ${ }^{9}$ The appearance of these sturdy and well-tended churches was not the only sign of religious change in Awrangabad during this period. The colonial prestige of British manners and (perhaps more surprisingly) architecture saw the sixth Nizām, Mahbūb 'Alī Khān (r. 1285/1869-1329/1911), celebrate his silver jubilee by placing a clock tower at the heart of Awrangabad's Shah Ganj market, from where it overlooked the shrine of Nizām al-dīn at the other end of the bazaar (Figure 4.1). Yet the official character of the state retained its Muslim orientation, notwithstanding the long tradition of religious syncretism in which the region's Sufis and shrines played so important a part.

By the late nineteenth century, the reformist impulse to defend Islam from both British and Hindu influence also reached the administration of Haydarabad. During the reign of Mahbūb 'Alī Khān the official character of the state became increasingly Muslim in orientation as the prestige of Mughal culture disappeared into the past. Modern administrative organizations were formed to oversee the religious life of the Muslims of the state, while new Hindu and Muslim missionary movements competed for the religious loyalties of the lower castes and country people. Official prominence placed on the Islamic character of Haydarabad gradually had a detrimental effect on relations between Hindus and Muslims. Under Mahbūb 'Alī Khān, laws were created to regulate the celebration of Hindu festivals, especially when they coincided with Muslim festivals, as occurred in $1303 / 1885$ with the 


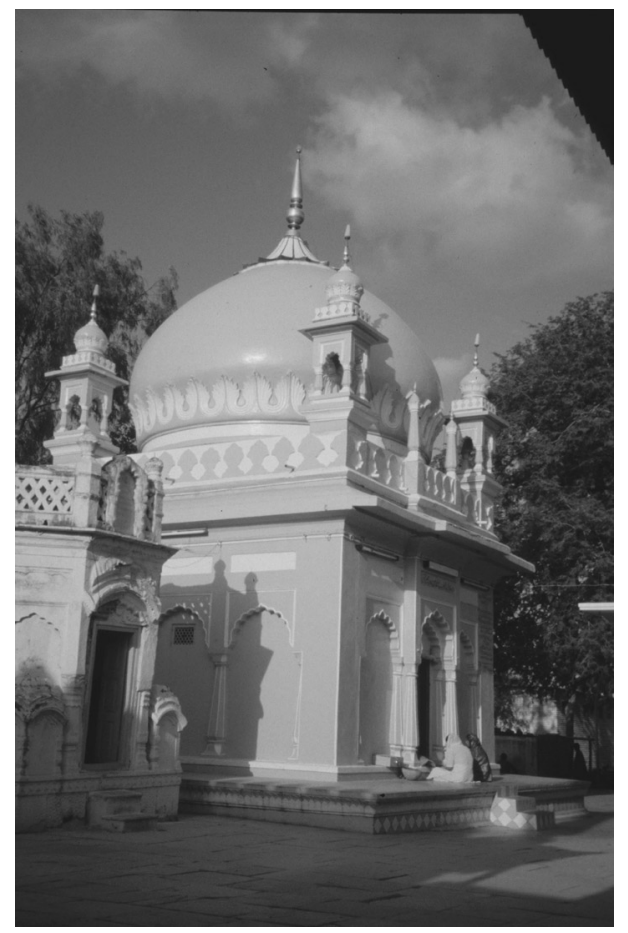

Figure 4.1 The mausoleum of Nizām al-dīn Awrangābādī.

coincidence of Dussehra and Muharram. ${ }^{10}$ Considering the long tradition of the common celebration of 'Ashūra, the tenth day of the month of Muharram, by both Hindus and Muslims in the Deccan, these administrative policies had great significance.

This period also saw the beginning of modern industrialization in Awrangabad, aided by its relative proximity to Bombay. Nonetheless, none of these economic, educational or administrative reforms were able to prevent the onset of famine and Haydarabad State (and the Awrangabad region particularly) continued to experience regular famines throughout this period, with Awrangabad catastrophically affected by the droughts of 1336-7/1918 and 1338-9/1920. Nevertheless, the city's population continued to grow, with growth exacerbated by the rural-urban migration caused by crop failures. In 1298/1881 the urban population of Awrangabad stood at some thirty thousand, which had risen to some thirty six thousand twenty years later. ${ }^{11}$ Nonetheless, the city remained a fraction of its size during its Mughal and early Āsaf Jāh heyday.

With the reform of the Āsaf Jāh administration under Sālār Jang and the promotion of a Haydarabadi nationalist ideology of Muslim modernism by some of his successors, the religious and political climate of the Deccan had greatly moved on since the age 
of Awrangzeb and Nizām al-Mulk. Yet connections with the region's Mughal and Muslim past remained strong and were in many ways encouraged in reaction to the rise of British power. The dethronement and exile of the last Mughal emperor, Bahadur Shah, by the British in $1274 / 1858$ had significant repercussions in Haydarabad State, whose coinage had until this point continued to be issued in the name of the Mughal emperor. After this date, Haydarabad's coinage replaced the name of the emperor with that of the state's founder Nizām al-Mulk Āsaf Jāh, along with the number ninety-two, signifying the name of the prophet Muhammad in the Arabic numerological (abjad) system. The final dissolution of the Mughal dynasty and its confirmation of British power contributed to a growing sense of the manifest destiny of Haydarabad to fly the standard of Islam. But the precise place and indeed definition of Islam in the Āsaf Jāh Deccan was by no means clear. As the Deccan's Sufi traditions show, there was a long tradition of interaction between Muslims and Hindus and a great deal of variety of Sufi and other expressions of Islam. However, once again migration played a part in this debate, for to the North Indian Muslims (termed ghayr-mulkīs or Hindustānīs) who moved to Haydarabad throughout this period, Islam was the key feature of the state's political and cultural identity. This was an ideology strongly influenced by the Aligarh movement, and many of Haydarabad's North Indian administrators were actual graduates of the AngloOriental College at Aligarh. But to many of the Deccan's inhabitants - the self-styled mulkīs - the Āsaf Jāh Deccan was the heir to a unique regional culture that, while deeply imbued with Muslim tradition, had nonetheless nurtured a distinctively Deccani approach to Islam and even at times transcended religious denominations altogether. Without projecting the terminology of the mulki $\bar{\imath}$ and ghayr-mulki conflict into areas in which they were never directly applied, the different orderings of identity that these two ideological banners represented can nonetheless be detected in many aspects of the Deccan's history during this period, in Awrangabad no less than elsewhere.

Yet if a pan-Islamic ideology began to gain the upper hand in Haydarabad's official circles during the reign of 'Uthmān 'Alī Khān (r. 1329/1911-1368/1948), the old spirit of Indo-Muslim court life continued to act as a model of the Deccan's social order. The Nawkhanda palace that had been the headquarters of Nizām al-Mulk in Awrangabad's days as Āsaf Jāh capital was maintained as the Nizām's residence in Awrangabad and used on his occasional visits. Nizām al-Mulk's throne room was maintained there and local notables and officials continued to stand in court before the throne $(\operatorname{gad} \bar{\imath})$ when the Nizām was present and on holy days when he was represented by the governor (sübedār). The British missionary Henry Lane-Smith described the scene on one such occasion in 1913, when after the ' $\bar{\imath} d$ festival prayers the firing of an old cannon announced the beginning of the procession to Nawkhanda, where two gaddīs were placed to represent the Nizām and his master in the new imperial order, the King-Emperor George V. ${ }^{12}$ On reaching the palace, as representative of the Nizām the sūbedār of Awrangabad bent low and first presented the imperial British throne with gifts of money, before sitting on the Nizām's throne to receive gifts of perfume, rose petals and rupees from the notables of the city in place of 
the absent Nizām. Like the identical acts of salutation and obeisance performed before the sajjäda nashins at the death anniversaries of the saints, the rituals at Nawkhanda echoed an older moral universe. But by now the Mughal emperor had long been replaced by a non-Muslim ruler, whose court lay much further away than Delhi.

\section{The Awrangabad saints and the British Empire}

\section{Nizām al-dīn}

In Chapter 3 we saw Nizām al-dīn's tradition flourishing in Delhi during the first half of the nineteenth century under the leadership of his grandson Qutb al-din and great-grandson Ghulām Nasīr al-dīn. ${ }^{13}$ Close to the last Mughal emperor and the poet Ghālib, Nasīr al-dīn upheld the memory of his ancestor Nizām al-dīn in the city in which the latter had originally studied under Shāh Kalīm Allāh. However, the later history of Nasīr al-dinn during the period of the Great Revolt is surrounded with uncertainties, like that of many Delhi families at that time. Nasīr al-dīn is sometimes regarded as having died in 1263/1845 long before the Revolt broke out, but this version of events is contradicted in a letter written by his close friend, Ghālib. In 1278/1862 Ghālib wrote to 'Alā' al-dīn Ahmad Khān (d. 1302/1884), claiming that Nasīr al-dīn had been unjustly put to death by the British in 1274/1857 when Delhi was recaptured. ${ }^{14}$ This version of events is also independently attested to in the oral tradition of the shrine of Nizām al-dīn in Awrangabad, where Nasīr al-dīn's descendants lie buried. Echoing Ghālib, the Awrangabad tradition claims that Nasīr al-dīn was executed as a result of his protecting a number of rebels whom he had counted among his disciples. In the aftermath of the Revolt, many notable Muslim families in Delhi disguised the involvement of family members in the uprising against the British. In this respect the existence of conflicting accounts of Nasīr al-dīn's demise is common to the history of many Muslim families in this period.

Nizām al-dīn's tradition was also linked to the events of 1274/1857 in other ways. We have seen his descendants acting as spiritual advisors to the declining Mughal court in the years in which Awrangabad became overshadowed by Haydarabad and Delhi. The consequences of the Great Revolt meant that the cultural and spiritual life of Delhi would never be the same. For alongside the deaths, financial ruin and temporary expulsion of the Muslim residents of Delhi was the destruction of much of the old city that lay around the last court of the Mughal emperors in the Urdū-e-mu'alā or 'Red Fort'. Partly through sheer revenge and partly through a strategy of clearing the hinterland of Delhi's principal stronghold, the British razed large sections of the Shahjahanabad (now known as Old Delhi) in which Nizām al-dīn's descendants had lived. It was here that the khanaqah of Shāh Kalīm Allāh stood, in which Nizām al-dīn had studied and around which Kalīm Allāh's descendants and disciples lived right up to its destruction. It is Ghālib again who describes the loss to literature and learning that accompanied the destruction of Kalīm Allāh's khanaqah in a moving letter to his friend Mawdūdī, who had written to him hoping 
to obtain copies of Kalīm Allāh's writings. In 1280/1863 Ghālib replied

Do you think that Delhi still flourishes when you ask after the writings of Hazrat Shaykh [Kalīm Allāh] and for news of Qutb al-dīn, son of Mawlānā Fakhr al-dīn? 'The cow ate the notebook, the butcher killed the cow and the butcher died on the road.' While the Emperor breathed all these things existed. But even Kālē Sāhib's [i.e. Ghulām Nasīr al-dīn's] house was destroyed as though a broom had swept it away, such that not a scrap of paper, nor a thread of gold, nor even a yarn of wool is left. The tomb (maqbara) of Shaykh Kalīm Allāh is now deserted. A fine village once flourished there, where all of the saint's descendants lived peacefully. Now it is just a wilderness, a tomb standing in the plain with nothing else beside. If any of the inhabitants survived the bullets, then God only knows what has become of them. It was they who kept Shaykh Kalīm Allāh's writings (kalām) and some of his relics (tabarrukāt). Now that even those people are no longer there, whom should I ask for the Shaykh's writings? ${ }^{15}$

Ghālib's letter eloquently expressed the mutually sustaining connections we have seen between Indian Sufism and the precolonial social order, as well as the way in which the memory of the saints and the legacy of their teachings was passed on through their family traditions. We have seen Nizām al-dīn posthumously celebrated through the efforts of his descendants in Delhi; here we hear Ghālib explaining that there was no one left in the family of Kalīm Allāh to maintain the legacy of Nizām al-dīn's master. It was not until several decades later that Kalīm Allāh's tomb was reconstructed through the intervention of the Punjabi Chishtī, Ghulām Farīd (d. 1319/1901). But unlike the Sufis of Delhi, Ghulām Farīd was still blessed with the patronage of an independent Muslim prince in the small kingdom of Bahawalpur.

As a close friend of Nasīr al-dīn, Ghālib's own fortune was also connected to that of Nasīr al-dīn's family. When Ghālib was desperate for money when the people of Delhi were forced out of the city in the darkest days of the Revolt, he asked his wife for her jewels and the other last valuables of the family. Hopelessly she then told him that she had hidden them in the cellar of their former host, Nasīr al-dīn, and had then sealed the cellar entrance with clay as a precaution against looters. But by the time Ghālib heard this, the British had already stormed Delhi and the city was burning; it was too late to return to recover the jewels and the family was destitute. Ghālib's interwoven destiny with the Chishtīs in Delhi rendered it appropriate that on the poet's death little more than a decade later, he was buried near the most famous of the Chishtī saints of Delhi in the shrine of his friend's ancestor's namesake, Nizām al-dīn Awliyā.

An account of how the Revolt affected both the last emperor Bahadur Shah II and Nizām al-dīn's descendants in Delhi is found in an obscure Urdu hagiography printed in Delhi almost fifty years after the events took place. This work, the Tadhkira-ye-Awliyāa-ye-Hind, was written by Mīrzā Muhammad Akhtar Dihlawī, the deputy (khali fa) of another of Delhi's Sufi masters and erstwhile contemporary of 
Nas̄ir al-dīn, Muhammad Dār al-Bakht Mīrān Shāh. ${ }^{16}$ In its section on Nizām al-dīn's son Fakhr al-dīn and his heirs, Mīrzā Muhammad's work contains the version of events surrounding the Revolt and subsequent exile of the last emperor remembered in the Sufi circles of Muslim Delhi. ${ }^{17}$ Mìrzā Muhammad begins with an account of Fakhr al-dīn himself, emphasizing how he continued Nizām al-dīn's support of musical performances and how on his deathbed he asked to be buried in a simple grave at the medieval shrine of Qutb al-dīn Bakhtiyār Kākī on the edge of Delhi. Mīrzā Muhammad informs us that a grand cenotaph was built for Fakhr al-dīn in any case and that in later years Bahadur Shah often spent time at the shrine and (as architectural historians well know) kept a mansion (dēorrhì) there. Mīrzā Muhammad then recounted a tale in which the spirit of Fakhr al-dīn was seen wandering alongside Qutb al-dīn himself in the gardens surrounding the shrine and mansion. With the same train of thought that in the imagination of his readers immediately connected mention of the emperor to his eventual surrender and exile to Rangoon, Mīrzà Muhammad then turned to a discussion of the politics of Delhi. According to his account, when Nizām al-dīn's descendant Nasīr al-dīn was away from the city performing the bajj, the British Resident in Delhi heard of this and deemed the absence of the emperor's spiritual guide a serious enough matter to inform the Governor in Calcutta. ${ }^{18}$ As a result, Nasīr al-dīn's sons, Nizām al-dīn and Ghulām Mu'in al-dīn, were implicated in the mutinous events in Delhi. Yet the ties between the families of Nizām al-dīn and the Mughal emperor continued even after the Revolt was quashed. For Mīrzā Muhammad tells us that in his Burmese exile the emperor missed the spiritual presence of Fakhr al-dīn so greatly that he asked to be sent a broom ( jārūb) from the saint's tomb so that he could be brushed with it. Mìrzà Muhammad also evoked the piety of the last emperor that was also echoed in his Urdu poetry by recollecting how Bahadur Shah had made no requests for cash or goods in Rangoon but only for the privilege of being buried beside the tombs of Qutb al-dīn and Fakhr al-dīn. We also know that it had been to this shrine that the emperor had fled on leaving his palace for the last time in 1274/1857. Delivering into the shrine's safekeeping the three sacred whiskers of the Prophet's beard that had been handed down to him by his forefathers, Bahadur Shah had sought the final blessing from the sajjāda nashīn Shāh Ghulām Hasan and left to take shelter from the British in the mausoleum of his ancestor, Humayun. ${ }^{19}$ But despite the supposed last wish of the emperor, in recognition of the heady political quotient of burying kings in the pilgrimage places of the saints the British administration ensured that the request was never granted.

Although by the end of the Revolt the emperor's spiritual master Nasīr al-dīn had certainly died, and like other families of Muslim notables his family had been suddenly impoverished, a number of his sons and particularly grandsons do seem to have survived the debacle. Mīrzā Muhammad gave a considerable list of their names in his Tadhira. ${ }^{20}$ Stepping back once more to a more direct source on the events, we find that the letters of Ghālib are once again a useful source on the fate of Nizām al-dīn's ancestors in Delhi. In 1277/1860, Ghālib wrote a letter in response to an enquiry about Nasīr al-dīn's family, in particular about Nasīr al-dīn’s son, Nizām al-dīn 
(d. 1292/1875 or 1295/1878), and his sons in turn. ${ }^{21}$ Ghālib described how Nasīr al-dīn's grandson, the unnamed son of this Nizām al-dīn, had fled Delhi in the wake of the Revolt at the same time as many other prominent men of the city and had travelled to Baroda, Awrangabad and Haydarabad. A year or so later he had returned to Delhi and been pardoned of his life by the British, who nonetheless seized the property which he would have otherwise inherited from the now deceased Nasīr al-dīn in the same way that they confiscated the property of other suspected mutineers. Nasī al-dīn's grandson forfeited his inheritance of the Rawshan al-dawla madrasa and the havelis of both Khwāja Qāsim and Nasīr al-dīn, which were then sold at auction and the proceeds collected by the British administration in Delhi. Describing this episode, Ghālib wrote that Nasīr al-dīn’s grandson had since left Delhi again, though it was unclear where he would settle. Yet Nasīr al-dīn's was by no means the only notable Sufi family to have members flee Delhi in the wake of the Revolt. Shaykh Ahmad Sa'īd, the sajjāda nashīn of the great Delhi Naqshbandī, Mīrzā Mazhar Jān-e-Jānān (d. 1195/1780), similarly fled the city before the British re-captured it, escaping through Punjab to the Afghan frontier, before eventually making his way to Madina, where he died in $1277 / 1860 .^{22}$ Surviving members of the imperial family made similar escapes across India and into non-British territory, in a few cases also eventually making their way to Haydarabad. Although it is extremely difficult to find reliable evidence on the fate of the imperial family, it seems that the emperor's son, Mīrzā Qu'wash, fled to Kathmandu after the Revolt before settling in the princely state of Udaipur. His son Mīrzā 'Abd Allāh later travelled to Awrangabad, before eventually settling in Haydarabad. There Mīrzāa 'Abd Allāh seems to have received support from the family of the Nizām and, as the Revolt gradually slipped further into the past, his son married into the family of the sixth Nizām, Mahbūb 'Alī Khān. ${ }^{23}$

In its account of the flight of Nasīr al-dīn's son and grandson, Ghālib's letter echoes the oral tradition maintained in Awrangabad. This tradition also describes one of the sons or grandsons of Nasīr al-dīn fleeing Delhi to escape the retributions that followed the Revolt. This son (or more probably grandson) of Nasīr al-dīn, Kamāl al-dīn, travelled from Delhi to Awrangabad and then Haydarabad with his two wives and children. When Kamāl al-dīn remained in Haydarabad, his son Sayf al-dīn settled in Awrangabad. There he took over the management of the shrine of his ancestor, Nizām al-dīn from either the descendants of Nizām al-dīn's disciple Shāh Sharīf or the caretaker (mutawal $\bar{\imath}$ ) who had been acting on behalf of the family in Delhi. While Kamāl al-dīn remained in Haydarabad until his death in 1327/1909, his body was brought to Awrangabad for burial in the shrine of Nizām al-dīn. ${ }^{24}$ The resting place of Kamāl al-dīn is marked at the shrine by an engraved headstone in front of the saint's mausoleum. Sayf al-din married into the family of the reviver of the cult of Shāh Nūr, Shams al-dīn of Haydarabad (who is discussed in the following sections), and continued to act as sajjäda nashinn at the shrine until his death in 1325/1907. He was then succeeded by his son (or, according to another version, his younger brother) Aslah al-dīn. Sayf al-dīn and Aslah al-dīn were both buried beside the mausoleum of Nizām al-dīn. After the death of Aslah al-dīn in 1357/1938, the leadership of the shrine came into the hands of his son, Mu'īn al-dīn (better known as Qaysar Miyān). 
In 1362/1943 Qaysar Miyān had his position at the shrine confirmed by an official proclamation ( farmān) from the last Nizām, 'Uthmān 'Alī Khān. ${ }^{25}$ He continued to act as sajjāda nashīn at the shrine until his death two decades later in 1385/1965.

With Aslah al-dīn, the leadership of the shrine of Nizām al-dīn in Awrangabad finally returned to the saint's own family. Aslah al-dīn was able to maintain the shrine by means of the lands ( $j \bar{a} g \bar{\imath} r s)$ in the surrounding region that had earlier been granted to the shrine. Unfortunately, almost all of the documentation of the shrine's earlier history was destroyed in a fire in the riots that accompanied the dissolution of Haydarabad state in 1368/1948, so the legal mechanisms by which Sayf al-dinn was able to regain control of the shrine and its landholdings remain unclear. Nonetheless, the lineage that he re-established was able to continue for the next century, ensuring that the annual ritual celebration of Nizām al-dīn's death could continue at his shrine in order to maintain his memory in the city in which he had been buried two centuries earlier. The following that Fakhr al-dīn had made in Delhi also ensured that the shrine in Awrangabad maintained occasional connections with the other Chishtī traditions that we have seen developing in North India during the nineteenth century. In Chapter 3 we saw Fakhr al-dīn's student, Muhammad Sulaymān (d. 1267/1851), achieving considerable fame as a Sufi master in his own right. In time his son and successor Khwāja Allāh Bakhsh (d. 1319/1901) developed his shrine at Tawnsa and its surrounding village in Punjab into an important centre of Sufi learning. ${ }^{26}$ As part of a combined programme for the economic and spiritual edification of his villagers, Allāh Bakhsh led groups of his local followers on extended trading visits cum pilgrimages to cities all around India that were the location of major Chishtī shrines, including Pakpattan, Delhi and Ajmer. When Awrangabad was also chosen for one of Allāh Bakhsh's expeditions, it was a further sign of the renewed status of Nizām al-dīn's shrine and of the renewal of its connections with North Indian Chishtī circles. $^{27}$

The revival of the shrine in Awrangabad through its connections with the Chishti traditions of the north drew further strength from the memory of Nizām al-dīn's connections with Nizām al-Mulk Āsaf Jāh. This memory became the focus of oral and written narrative traditions glorifying Nizām al-dīn's command of powers of vast consequence, ultimately painting him as the supernatural founder of Haydarabad State. The eventual result was the rise of Nizām al-dīn to the point of eclipsing the prestige of the other saints of the city despite his earlier overshadowing by Shāh Nūr and Shāh Musāfir. This success was the result of a determined effort to tie Nizām al-dīn's name into the Sufi technology of memory comprising commemorative texts (tadhkirāt) and lineage structures (silsila) which placed Nizām al-dīn midway between the grand early Sufis of medieval Delhi and the later Sufis of colonial North India. Here was the late return on Fakhr al-dīn's investment in commissioning and taking with him to Delhi the Absan al-shamā'il of Kāmgār Khān, the first textual stage in the making of Nizām al-dīn's fame. The nineteenth-century rise of Nizām al-dīn's reputation continued in the first half of the twentieth century, when legends recounting his miraculous aid in the foundation of the Āsaf Jāh state continued to be popular throughout Haydarabad. In 1331/1912, these claims to the saint's secret 


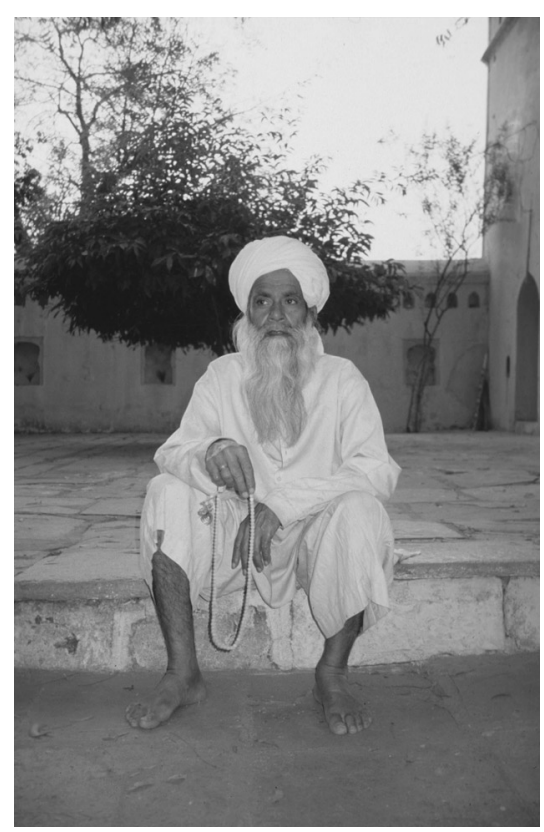

Figure 4.2 A Sufi pilgrim at the shrine of Nizām al-dīn Awrangābādī.

founding of the state featured in the century's most important tadbkira of the Deccan saints, written by 'Abd al-Jabbār Khān Malkāpūrīi. ${ }^{28}$ From a few decades earlier, we also have proof of the continued reading of Nizām al-dīn's malfūzāt, the Absan al-shama'il. This is found in the writings of the Haydarabadi notable and Chishtī Sufi, Shāh Habīb 'Al̄̄ Shāh (d. 1323/1905). Both his Habīb al-Tālibìn and Habīb al-Barāzikh make reference to Nizām al-dīn, whom Habīb 'Alī counted as his predecessor in the Deccan. At one point in the Habīb al-Tälibìn, Habīb 'Alī drew upon Kāmgār Khān's accounts of Nizām al-dīn's practices during the ritual of musical audition (mabfil-e-sam $\bar{a}$ ), while elsewhere in the same work he referred to the saint as the 'master of the spiritual jurisdiction of the Deccan (säbib-e-walāyat-e-dakan)'. ${ }^{29} \mathrm{Habīb}$ 'Alī's Habīb al-Barāzikh also featured references to Nizām al-dīn with the same title, similarly making use of the Absan al-shama'il. ${ }^{30}$ Yet even with Habīb 'Alī in the heart of the Deccan at Haydarabad, this Sufi's initiation into the lineage of Nizām al-dīn had not come directly from Awrangabad but had passed through several generations of his son Fakhr al-dīn's followers in North India before Habīb 'Alī was initiated into the Chishtiyya by Hāfiz 'Al̄̄ Shāh (d. 1266/1850) of Khayrabad in North India during one of his visits to the Deccan. ${ }^{31}$ Once again, Hindustan maintained its pre-eminence over the Deccan as the fountain of the Chishtī saints.

In Awrangabad at this time, the sajjāda nashīns of Nizām al-dīn were regarded as important figures and were recognized as the chief representatives of the Chisht $\overline{1}$ 
order in the city. When the deputyship to a new Sufi saint in Awrangabad, Banē Miyān (d. 1339/1921), was being authorized in 1335/1916, the spiritual authority of the sajjāda nashīn of Nizām al-dīn was called upon when he was asked to witness and sign the sanad-e-khiläfat document recognizing Banē Miyān's appointment of his nephew. ${ }^{32}$ However, other Sufi masters were also active in the city at this time whose links with the Chishtiyya did not necessarily come through the shrine of Nizām al-dīn. One such Chishtī Sufi was Mawlwī Muhȳ̄ al-dīn, who was active in Awrangabad in the last years of the nineteenth and the beginning of the twentieth centuries. Muhȳ̄ al-dīn is of particular interest in having initiated Ahmad Hasan Mawdūdī (d. 1339/1920), the father of the founder of the Islamist political party Jamā'at-e-islāmī, Abū 'Alā' Mawdūdī (d. 1399/1979), into the Chishtī order in around 1318/1900. ${ }^{33}$ Ahmad Hasan Mawdūdī was a lawyer from Delhi who like so many other North Indians migrated to Awrangabad in 1314/1896 to work in the Nizām's civil service. Echoing the old pattern of engagement between the Sufis and the grand figures of politics, the birth of Abū 'Alā' Mawdūdī was said to have been predicted by a Sufi in Awrangabad. His father Ahmad Hasan's spiritual passions were such that in 1322/1904 he left Awrangabad to return to Delhi and live the life of a mendicant faqīr at the shrine of Nizām al-dīn Awliyā. In 1325/1907 he was summoned back to Awrangabad by his spiritual master Muhyī al-dīn after his spiritual excesses had reduced his family to destitution. If little more is known of Muhyī al-dīn himself, the trajectory of Ahmad Hasan's spiritual life echoes the way in which Nizām al-dīn's Chishtī tradition in Awrangabad retained its connections to Delhi during this period through a continuation of the same patterns of migration that had first tied Delhi to Awrangabad centuries earlier.

\section{Shāh Nūr}

At the turn of the twentieth century, Shams al-dīn Chishtī (d. 1347/1928) arrived in Awrangabad to resuscitate the dormant cult of Shāh Nūr. ${ }^{34}$ Shams al-dīn was a resident of Haydarabad, who had been living for many years at the shrine of $\mathrm{Mu}^{\mathrm{i}} \mathrm{i} n$ al-dīn Chishtī in Ajmer. Hagiographic and oral tradition relate Shams al-dīn's arrival at Shāh Nūr's shrine in classic Sufi form, describing a visionary encounter with Mưīn al-dīn Chishtī that summoned him to tend to the tomb of Shāh Nūr; it is a motif that is familiar from Muslim shrine cults the world over. ${ }^{35}$ Shams al-din's arrival in Awrangabad reflected the wider movement of religious revival in both Haydarabad State as a whole and within the Sufi circles of Awrangabad in particular. ${ }^{36}$ The survival of Haydarabad as an independent Muslim state capable of patronizing Muslim religious figures made it an attractive destination for an array of mystics, poets and scholars. And as the second city of the state, Awrangabad received the overspill of religious figures from the capital at Haydarabad. By the turn of the twentieth century, it was no longer Delhi or the more distant cities of Central Asia or Iran that provided Awrangabad with the majority of its Sufis. Now Haydarabad itself came to act as the principal exporter of Sufis to Awrangabad and other cities in the Deccan. But despite the large number of new Sufi traditions being founded 
throughout the Haydarabad Deccan at this time, Shams al-dīn is interesting as an example of a founder of a new religious tradition who anchored himself to the firmer foundations of an older one in order to secure his reputation. Although Shams al-dīn was connected to the Chishtī order, into which he had been initiated in Ajmer, it was through the combination of his own charisma and his institutional position as the representative of Shāh Nūr that he was able to begin a new Sufi tradition in Awrangabad that would continue long after his death.

Despite the stories of Shams al-dīn's visionary designation by Mu'īn al-dīn Chishtī as Shāh Nūr's successor, his appointment at the shrine seems to have been an official one made by Haydarabad's Department of Religious Affairs. Nonetheless, Shams was clearly of a religious disposition and took to his work at the shrine with great gusto. His arrival in Awrangabad and eventual assumption of the role of sajjäda nashin heralded the beginning of the second career of Shāh Nūr's shrine after its abandonment in the nineteenth century. Shams set about restoring the derelict buildings of the shrine, replacing roofing and floors that had collapsed or disappeared and re-initiating the celebration of Shāh Nūr's death anniversary. ${ }^{37} \mathrm{He}$ also beautified the shrine with new gardens and erected an iron roof over the platform before the saint's mausoleum to shelter the female pilgrims who were not allowed into the mausoleum itself. Shams al-dīn also seems to have counted the Nizām's Hindu prime minister, Kishan Parshād, among his followers. Kishan Parshād was dīwān of Haydarabad State from $1320 / 1902$ to $1329 / 1911$ and was also connected with the patronage of the shrines at Khuldabad, about whose saints he wrote a hagiography in Urdu. He enlisted Kishan Parshād's help in his renovation projects at the shrine, redirecting some of the water from the underground water channel (nehr) connected to Kishan Parshād's haveli in the old city into a channel running to Shāh Nūr's shrine, which had run dry from years of disuse. ${ }^{38}$ Other Sufi shrines in the region were also repaired or beautified during this period, as at the shrine of Jān Allāh Shāh (d. 1093/1682) at nearby Jalna, where an engraved silver portal and matching set of gates were added to the mausoleum in 1329/1911. However, the revival of the shrine of Shāh Nūr was also reflected in a number of literary accounts of the saint written during the early decades of the century, particularly that of 'Abd al-Jabbār Khān Malkāpūrī.

Associations with an earlier clientele were to some extent re-awoken through Shams al-dīn's family connections in Haydarabad. The Nizām's Hindu prime minister, Kishan Parshād, and his minister for religious affairs (umūr-e-madhhab̄), Fazîlat Jang, became associated with the shrine, renewing its earlier connections with high-ranking state officials. One source even reports that Fazilat Jang became the administrator (mutawali $)$ of the shrine after Shams al-dinn's death. ${ }^{39}$ The suburb of the city in which the shrine is situated became known during this period as the Sipāhī ('Cavalry') Bāzār and cavalrymen from the Hyderabad Contingent were noted as the principal devotees of the shrine during this period. ${ }^{40}$ While Indian soldiers serving in the Contingent were also connected to the cult of the early twentieth-century Sufi of Awrangabad, Banē Miyān, it is more difficult to assess the claims of both the hagiographers of Banē Miyān and Shāh Nūr writing in the first half of the twentieth century that Englishmen (angrezz) were also counted among the followers of these 
saints. ${ }^{41}$ While this may be read as a classic hagiographical tendency towards cultic exaggeration, the visitation of Indian soldiers to these saints does suggest other possibilities. Given the presence of a British officer class serving with the Contingent in Awrangabad, it seems possible that some of these officers may have accompanied their men to the shrine either out of curiosity or for the pleasure of the ride into the rural suburb where the shrine was located. We know that numerous Britons visited Panchakkī as a picturesque excursion during this period. It would be an interesting inter-cultural misreading of motive if these pleasure visits were interpreted by locals as being pilgrimages like their own.

By piously working in the service of Shāh Nūr, Shams al-dīn gradually attracted a circle of followers of his own, both in Awrangabad and Haydarabad. Being appointed as the representative of the Mughal saint clearly aided Shams al-dinn in establishing his reputation in the region as a religious authority in his own right. Whatever the nature of the spiritual connection between Shāh Nūr and Shams al-dīn, the administrative connection instituted by Shams al-dīn's appointment at the shrine brought with it a considerable dividend of veneration. For in life as in death, possession of a shrine was half of the proof of sainthood. The growth of Shams al-dinn's reputation beyond Awrangabad is seen in his connection to the cult of the famous religious teacher Sā̄i Bābā of Shirdi (d. 1337/1918), who regularly visited Awrangabad during his youth and possibly resided there for several years. Sāì Bābā was an heir to the Sufi traditions of the Haydarabad Deccan, even though the religious politics of independent India would later gradually de-Islamicize his cult and memory. One anecdote from his life describes him sending Qāsim, the son of one of his closest disciples, to Awrangabad to meet Shams al-dīn. ${ }^{42}$ According to Qāsim's companion, Imāmbhāì Chōtā Khān, Shams al-dīn was waiting for the pair when they arrived at the newly opened railway station in Awrangabad, a journey of around two miles from the shrine by carriage. According to the account, Shams al-dinn was already mystically aware of Sāi Bābā's command that the pair should present 250 rupees to Shams al-dīn for the performance of praise songs (mawlīd, qawwālì) at the shrine of Shāh Nūr for the Prophet Muhammad and the saints. Sāī Bābā had also prepared local unleavened bread $(p o l \bar{\imath})$ and chicken for Shams al-dinn to distribute to the poor at the shrine, in an offering often associated with the saintly shrines of the Deccan.

Shams al-dīn's arrival in Awrangabad heralded the introduction of a new Chishtī association with the shrine of Shāh Nūr through Shams al-dīn's own prior attachment to $\mathrm{Mu}^{\text {'ìn }}$ al-dīn Chishtī at Ajmer. This involved the introduction of elements of Chishtī practice to the shrine, notably the presence of bands of Sufi praise singers (qawwāls) and the construction of a special hall (sama'khāna) for these performances and the ecstatic dancing associated with them. These innovations reflected broader cultural changes in the Deccan that were concomitant with the re-evaluation of the region's Muslim heritage in the age of Indian nationalism as reflected in a growing sense of the 'Indianness' of the Chishtiyya. The shrine of Shāh Nūr also revived its khanaqah during this period and during the 1920s the presence of some thirty to forty faqīrs was reported there. ${ }^{43}$ Such mendicants seem to have remained at the shrine until the dissolution of Haydarabad State in 1368/1948, with 
similar numbers of Sufi mendicants maintained at other shrines in the city at this time. The sheltering and feeding of such dervishes was often a condition of the endowments which supported shrines. A document dating to as late as 1278/1861 and relating to the family of Shāh Imām al-dīn, a nineteenth-century sajjāda nashīn of the eighteenth-century Awrangabad Sufi, Shāh 'Alī Nehrī, clearly stipulated that the revenue assigned to his family should also be used for the expenses of the faqirs resident at Shāh 'Alī's shrine. ${ }^{44}$ However, modernity also brought with it new priorities and, reflecting the revival in educational projects in the city's religious institutions also reported in the missionary papers of Rev. Henry Lane-Smith, a new madrasa was opened at Shāh Nūr's shrine during the years of Shams al-dīn's management.

Shams al-dinn continued with his projects at the shrine for over two decades until his death in 1347/1928. ${ }^{45}$ He was buried directly beside Shāh Nūr, with a dome constructed over his tomb some years later. ${ }^{46}$ This construction was of great symbolic importance, in that the earlier eighteenth-century line of sajjäda nashins was buried more than twenty feet away from the grave of Shāh Nūr and without a single dome between them. With Shams al-dīn's own reputation architecturally confirmed, a new lineage of sajjäda nashins emerged among his descendants after his death. But although these sajjāda nashins remained resident at the shrine and continued to offer a source of blessing and, to some extent, actual Sufi instruction to a number of followers, their authority was later challenged by the establishment of a committee, which was to gain broader control of the shrine's activities. The foundation of this committee was a reflection of the modernizing patterns seen at shrines throughout the Muslim world in the twentieth century, including at Panchakkī a few miles away at almost exactly the same time. But Shams al-dīn's status was not so easily undone. Three decades after his death a further domed burial chamber of identical design to that of Shams al-dīn was added to the southern front of Shāh Nūr's mausoleum in honour of Shams al-dīn's successor in his new lineage of sajjäda nashīns.

While Shāh Nūr's cult again flourished in Awrangabad during the first half of the twentieth century, its sister cult of Shāh Nūr's reputed Hindu companion at Dawlatabad also continued to thrive. This was the cult of Mānpūrī Parshād at his lodge (math) in the village at the foot of the great citadel of Dawlatabad a few miles outside Awrangabad. In the math two eighteenth- or nineteenth-century miniature paintings of Shāh Nūr and Mānpūrī were preserved side by side, presenting the two saints in the simple imagery of the Indian ascetic, devoid of any overtly Muslim or Hindu iconography. Mānpūrī's religious songs (bhajans) were also preserved and sung at his math throughout the nineteenth and twentieth centuries, lyrics which presented a path of devotion to the spiritual master as the key to religious advancement and which frequently scorned the external formalities of religious practice. While the precise character of Mānpūrīs cult at Dawlatabad under the Nizāms remains unclear, modern oral tradition in Dawlatabad maintains that the math was always a focus of pilgrimage for both local Muslims and Hindus. Certainly, at the end of the twentieth century Mānpūrī’s Muslim devotees claimed devotion to Mānpūrī as their ancestral tradition and there seems little reason to doubt them. 


\section{The Saints of Panchakki}

The extensive landholdings that Panchakkī had collected during the first century and a half of its existence meant that the family of its sajjäda nashins were able to maintain a high standard of living as long as Haydarabad and its laws of Muslim endowments (awqāf) survived. For much of the second half of the nineteenth century, the shrine was controlled by Shāh Hamīd Allāh, the fifth sajjāda nashīn who had inherited his position on the death of his childless elder brother, Amīn Allāh. ${ }^{47}$ While nothing is known of the lives or character of these two figures, surviving documentation from the shrine during the early twentieth century confirms the wealth that Panchakki continued to possess by way of earlier land grants. Supported by the shrine's landholdings, the sajjāda nashīns of Shāh Musāfir continued to live in grand style, maintaining the fountains and pools of the shrine in addition to the large pleasure garden that had developed around Panchakkī by this time. Yet such wealth brought with it duties of its own, and the sajjāda nashīns of Panchakkī are best seen as representatives of what still remained a Sufi religious establishment in provincial Haydarabad rather than as land-owning aristocrats tout court. ${ }^{48}$ An example of the moral imperatives of such wealth is seen in an anecdote from $A^{\prime} z a m$ al-karāmāt, the hagiography of the early twentieth-century Sufi, Banē Miyān, written at the beginning of the 1920s. The text recounts the story of how in the early twentieth century the sajjäda nashīn of Panchakkī took pity on one Sarwar Khān, a pious but poor Muslim of Awrangabad, and helped him to fulfil his religious duties by paying for him to accompany the sajjäda nashinn's own extended party on the hajj to Mecca. ${ }^{49}$

The unnamed sajjāda nashīn of Panchakkī whose charity was described in $A^{\prime} z a m$ al-karāmāt was almost certainly Shāh Ghulām Mahmūd (d. 1339/1920). Ghulām Mahmūd had inherited his position upon the death of his father Hamīd Allāh and throughout his years as sajjäda nashīn won renown for his piety and learning, as well as for his efforts to beautify the gardens and maintain the buildings of Shāh Musāfir's shrine. ${ }^{50}$ The sajjāda nashīns of Panchakkī evidently still received sufficient income from the shrine's landholdings to maintain the costly delights of fountains, feasts and festive lighting and a limited number of dervishes continued to reside in its khanaqah at the sajjāda nashīn's expense. ${ }^{51}$ Although Panchakkī's clients were fewer than in its early age of greatest influence in the Mughal period and its blessing power now of limited distribution, it was nonetheless able to find a role for itself as the epitome of the city's Mughal connections and Sufi piety. The tradition of scholarship with which the shrine had become associated during the second half of the eighteenth century also combined with the leisurely pursuits of this wealthy class of sajjäda nashins and a surviving inventory of the shrine's library also shows that book collecting continued at Panchakkī during the second half of the nineteenth century. ${ }^{52}$ Indeed, the reputation of Panchakkîs library was distinguished enough in the early decades of the twentieth century to warrant regular visits by the famous scholar and lexicographer of Urdu, Mawlwī 'Abd al-Haqq (d. 1381/1961). ${ }^{53}$

The saints' connections to a long-gone Central Asian military aristocracy meant that their later representatives' attempts to establish a wider constituency in 
Awrangabad were handicapped. But the saints were nonetheless able to maintain a limited local clientele, who took for granted the tradition that had developed over the centuries that Shāh Musāfir had been the spiritual master of the great emperor and founder of their city, Awrangzeb. Locals also continued to resort to the shrine as a place of pleasure and delight. These promenades of Awrangabad's Indian residents were supplemented by regular visits by the Britons stationed in the city's cantonment, for whom the shrine and its gardens on the outskirts of the old city became a favoured place of recreation. In the 1860s, one British visitor, Major Robert Gill, wrote of Panchakkī that, 'the place is much resorted to by the English for purposes of eating and drinking: by the Moslems, and even Hindoos, in honor of the Peer [i.e. Shāh Musāfir], and for purposes of veneration. ${ }^{, 54}$ The English novelist E.M. Forster was similarly treated to a picnic by his Indian hosts in the gardens of one of Awrangabad's Mughal tombs. Although surviving accounts of the visit suggest that this was not actually Panchakkī, we may probably assume that he did visit the shrine on his nostalgic tour of the city's sights in $1913 .{ }^{55}$ The picturesque qualities of the shrine also made it a favoured site for early photographers and in addition to the five photographs of the shrine published by Major Gill and his companion James Ferguson in 1864, the court photographer of the Nizām, Rājā Musāwir Jang (better known as 'Raja Deen Dayal', d. 1905), also took several pictures of Panchakkī during a visit to Awrangabad in the 1880 s. ${ }^{56}$ For as much as anything else, by this period Panchakki acted as a vivid architectural reminder of the glory of the city's imperial past. The visits made by local people were perhaps aimed as much at connecting with that past than with the saintly persons of the Sufis buried there, for the splendid shrine of the saint now regarded as Awrangzeb's spiritual mentor seemed to embody the history of the entire city.

If the turn of the twentieth century saw the cult of Shāh Palangpōsh and Shāh Musāfir surviving only as a minor saintly tradition, it was nonetheless a tradition endowed with great wealth. The combination of a saintly Central Asian ancestry and a large income from the shrine's landholdings positioned the last sajjäda nashins of Shāh Musāfir at the top of Awrangabad's social ladder. And yet a sense of family tradition and religious duty led Ghulām Mahmūd, the last of the original line of sajjāda nashīns founded by the author of the Malfüzāt-e-Naqshbandiyya Shāh Mahmūd, to uphold what remained of the shrine's spiritual tradition. ${ }^{57}$ Ghulām Mahmūd was reputed for his conscientiousness with regard to the performance of the death anniversaries of the Panchakkī saints and the other religious functions of the shrine. But when Ghulām Mahmūd died without issue in 1339/1920, the first of a long series of disputes began for control of the shrine that would continue in one form or another for the remainder of the century. Although he had no children, Ghulām Mahmūd did leave two wives, Sāliha Bēgam and Batūl Bēgam, who were determined that control of both the shrine and its landholdings should remain in their hands. ${ }^{58}$ Despite some success with the government in Haydarabad, as at the shrine of Shāh Nūr, in the late 1920s a management committee (intizām $\bar{\imath}$ komìt $\bar{\imath}$ ) was set up to replace them. The committee was placed under the chairmanship of the governor (sübedār) of Awrangabad and consisted of members of the Nizām's civil service and a 
number of non-governmental figures. The scale of Panchakkî's landholdings, and the thought of their sole control by two elderly women, also seems to have been a cause for considerable disquiet in the city at large. But despite these attempts to depose them, Ghulām Mahmūd's widows seem to have been determined and capable women. Since it was Sāliha Bēgam who was responsible for saving the sole manuscript of the Malfüzāt-e-Naqshbandiyya upon the death of her husband and seeing to its eventual publication in Haydarabad, we too have much to be grateful to her for. ${ }^{59}$ But when the two widows both died some time in the early 1930s, the property and landholdings of the shrine finally fell firmly into the hands of Haydarabad's Department of Religious Endowments. But this was not the end of the old ways of individual control by a representative of the saint and a nephew of Ghulām Mahmūd who had enjoyed the favour of Sāliha Bēgam (and claimed to have been formally adopted by her) came forward to claim the position of sajjäda nashinn. While the shrine's lands had been seized by the state, this claimant, Yūsuf al-dīn Maghribī, remained in residence at Panchakkī and began the first of a long series of court cases to reclaim the lands (or later a stipend based upon them) from the government. The era of Panchakkì's independent wealth had come to an end.

\section{The literary tradition}

\section{An overview}

The nineteenth century saw far less literary activity in Awrangabad than the wealth of writing that characterized the century before it. The increasing poverty of Haydarabad's landholding classes and the focus of what patronage there was on Haydarabad played some role in this. However, a limited amount of literary production did continue in the city, even though literary careers started there could often only be continued elsewhere. Probably the most significant local writer from the early part of this period was 'Ināyat Allāh (fl. 1273/1856), whose Y $\bar{a}$ Fatāh continued the earlier tradition of urban literary celebrations. ${ }^{60}$ However, the literary scene in Awrangabad in the second half of the nineteenth century is perhaps best evoked in the life of the poet of Urdu and Persian, Ghālib’s friend Miyān Dād Khān Sayyāh (d. 1325/1907). ${ }^{61}$ Born into a noble family in Awrangabad, Dād Khān saw his family reduced to poverty in his youth before beginning the series of travels that led Ghālib to give him his nom de plume of Sayyāh ('traveller'). This sobriquet echoed the title of Awrangabad's great Naqshbandī saint, Shāh Musāfir (the 'traveller king') that in turn echoed the long-standing convention of tying together the language of the mystical quest with that of travel, both seen as typified by hardship and discovery. As a lover of fine clothes and perfume despite his poverty, Dād Khān later spent some years as the companion of the Surat nobleman Nawwāb Mīr Ghulām Bābā Khān (d. 1311/1893), but ultimately died in poverty in 1325/1907.

The promotion of Arabic and Islamic scholarship was also given renewed attention as Haydarabad developed a renewed sense of purpose and legitimacy as the last great defender of Islam in India. It is often overlooked that the great early star of the 
Muslim anti-colonial movement Jamāl al-dīn 'al-Afghānī' (d. 1314/1897) resided in Bombay and Haydarabad between 1296/1879 and 1299/1882. ${ }^{62}$ While he was in Haydarabad, al-Afghān̄ received the patronage of a local aristocrat and wrote his major work Haqīqat-e-madhbab-e-naycharī wa bayān-e-bāl-e-naychariyān in opposition to the ideas of Sayyid Ahmad Khān and the Aligarh Movement. This work was first published in Haydarabad in Persian in 1298/1881, several years prior to its translation into Arabic as al-Radd 'ala al-dhabriyyin ('Refutation of the Materialists'). Mapped out in the shifts of patronage between Arabic, Persian and Urdu were the various ideological dimensions of the struggle between pan-Islamism and local nationalism that characterized the intellectual parameters of the struggle for the souls of Haydarabad's Muslim intellectuals. These linguistic debates were of great consequence, for they would determine which linguistic community Haydarabad's Muslims - and even Hindus - would belong to, from a pan-Islamic tradition of Arabic scholarship to the tradition of Persian learning that had for centuries tied India into a wider cultural ecumene encompassing Central Asia and Iran, to Urdu and ultimately the strictly regional vernaculars of Telugu and Marathi. Lost in the middle ground between the Arabic of the pan-Islamists and the Urdu of the Deccani and Indian nationalists, Persian learning was the first casualty of Haydarabad's twentieth-century linguistic struggle for identity. In the first half of the nineteenth century Persian had been able to retain its prominence in India, but its replacement as the official language of British administration by English in the 1830s was reinforced in the Deccan in 1301/1884 by Persian's replacement by Urdu as the official language of the Āsaf Jāh administration. While Arabic scholarship continued to receive patronage, the fortunes of Urdu rose quickly over the following decades. And with the other historic centres of Urdu in Delhi and Lucknow firmly under British control, Haydarabad came to see itself as the last great protector of Urdu no less than of Islam.

These debates were also echoed in the development of scholarship in English in Haydarabad, where the influential scholarly journal Islamic Culture was founded in $1345 / 1926$ with an editorial board that was dominated by immigrant (ghayr-mulkì) intellectuals sympathetic to the brand of Muslim patriotism they saw as the true spirit of Haydarabad. ${ }^{63}$ Such a pan-Islamic ideology could certainly appeal to a wider audience than the people of the Deccan itself, and alongside al-Afghānī also attracted the English scholar and convert to Islam Marmaduke Pickthall (1875-1936) to move to Haydarabad, where he served as an educationalist in the Nizām's service and became the editor of Islamic Culture. However, the greatest legacy of Pickthall's association with the Deccan was his famous translation of the Quran, which he dedicated to Nizām 'Uthmān 'Al̄̄ Khān.

Subsequently, the late nineteenth century saw a considerable flourishing of Urdu scholarship in Haydarabad, with Urdu finally establishing itself as a prose medium of comparable stature with Persian. This was not least the case in the realm of historiography, and through the writings of Ghulām Imām Khān and Amjad Husayn, khātib of the Friday mosque at Ellichpur in the northern Deccan, among others, the foundations of a modern tradition of historical reflection on Haydarabad's 
history were laid. ${ }^{64}$ In Awrangabad, the promotion of Urdu learning was bolstered through the foundation of a local branch of the Society for the Promotion of Urdu (Anjoman-e-taraq $\bar{\imath}-y e-u r d \bar{u}$ ) in 1321/1903. This institution was later managed in Awrangabad by the famous scholar Mawlwī 'Abd al-Haqq, known for his services to Urdu scholarship as Bābā-ye-Urdū ('Father of Urdu'). The Awrangabad branch of the Anjoman oversaw a great flurry of publishing, with earlier generations of what were by now judged as literary classics being published for the first time, along with a series of newer and lesser known works. A firm characteristic of the Anjoman was the publishing of poetry composed in the Deccan, from the Dakhani literature patronized by the Qutb Shāhs of Golkonda through to important editions of the poems of Awrangabad's own Sirāj and Walī. The establishment of one of the earliest Urdu literary journals, called simply $U r d \bar{u}$, added a critical dimension to this appreciation of literary tradition by encouraging analysis instead of the more partisan critical traditions of outright praise and defamation. In 1933, 'Abd al-Haqq himself wrote an important work on the role of the Sufis in the early evolution of Urdu literature in the Deccan. ${ }^{65}$

Despite the succour offered by the independence of Haydarabad, this was still the heyday of Britain's colonial influence and this entry of a canon of Urdu classics into print occurred alongside the translations from European literature that would have such great effect on the Urdu literary imagination across India over the coming decades. Throughout this movement, the shadows of an earlier age of empire still lingered, and the establishment of Urdu as the official language of the state saw a split between those who wished to promote the more Persianized Urdu of North India over the vocabulary and norms of Haydarabad's own Dakhani Urdu tradition. The Anjoman-e-taraq $\overline{-}-y e-u r d \bar{u}$ was only one of a number of similar institutions that represented Haydarabad's attempts at modernization. Breaking with the old traditions of madrasa education, in 1337/1918 the city of Haydarabad saw the opening of the first Urdu-medium university, the Osmania University, while in the 1890s a modern school was established in Awrangabad. Alongside the churches in Awrangabad and the schools attached to them, these new institutions provided strong competition for the madrasas and shrines that had for so long supported learning in the region. The new schools were to have a considerable effect and between 1298/1881 and 1350/1931 the Muslim literacy rate doubled in Haydarabad State, especially with regard to literacy in Urdu. ${ }^{66}$

During the first half of the twentieth century, these seismic shifts in language use, literacy and the technology of the book had a considerable influence on the literature surrounding Awrangabad's saints. Reflecting the declining fortunes of Persian throughout India, the nineteenth-century tadbkira tradition experienced a certain discontinuity with the rise of Urdu prose. Contemporary with this was the spread of cheap lithographic printing in India, which affected the Awrangabad tradition in different ways. For while Persian was certainly declining in India, it did receive an important buttress through the printing of what were considered notable (and marketable) works of Persian literature. And several works related to the Awrangabad Sufis did make the transition into print from the great Persian publishing centres of 
Delhi, Lucknow and Kanpur in the north. Given the rise we have witnessed in the reputation of Nizām al-dīn in northern India throughout the nineteenth century, it is a matter of little surprise that these works were principally related to his tradition rather than that of any of the other Awrangabad saints. North Indian publishers printed lithographic editions of Nizām al-dīn's own Nizām al-qulūb and the collection of letters addressed to him by Shāh Kalīm Allāh. Several texts relating to the circle of his son Fakhr al-dinn were also published around this time. Since these were effectively all commercial editions, the appearance of these works is testament to the interest which North Indian Muslims maintained in the lineage of Kalīm Allāh in spite of the destruction of his shrine, and the manuscripts contained there, by the British in the aftermath of the Revolt. Awrangabad was also fortunate in seeing the works of some of its best known writers, such as Shāh Nawāz Khān and Bilgrāmī, finding their way into print relatively early, while the Anjoman published a great deal of the Urdu poetry produced during the city's early history. For the most part, however, the works describing the city's saints would either wait until the mid- or late twentieth century to be printed, with many works never being printed at all and only surviving as rare or in some cases unique manuscripts. The coming of the printing press, and the question of which works passed over into print, thus represented an important change in the worlds of Indo-Muslim memory and learning in Awrangabad. With so many of the texts related to the city and its saints forgotten or in some cases lost for good, much of what was remembered by the new generation of Urdu hagiographers in the twentieth century changed the character of the saints in subtle ways as the old texts and the world they represented were forgotten.

\section{Urdu hagiography in a changing environment}

The first half of the twentieth century saw a renewed albeit limited interest in Awrangabad's saints by a new generation of Deccan-based commemorative writers. Although their accounts retained the saints' by now patrimonial connections with $\bar{A}$ saf Jāh statehood, there was also room within them to redefine the identity of Muslim sainthood itself in accordance with the changing intellectual climate in India. It was mainly the development of this tradition of Urdu tadhkirāt that provided the means by which the memory of the saints was passed on to modern times after the collapse of literary participation in Persian. Sufi biographical writings formed part of this growth of Urdu prose writing and Awrangabad also saw the composition of Sufi texts in Urdu by residents of the city attached to the new Sufi tradition of Banē Miyān, as well as the featuring of its older Mughal saints in new Urdu Sufi biographical texts written elsewhere in the Deccan.

We have seen that the first half of the nineteenth century witnessed the production of numerous Sufi biographical writings in Persian as Indian Muslims became increasingly conscious of the fragility of their heritage. Amid these works, Nizām al-dīn stood out among the Awrangabad saints through his inclusion into what may be seen as the self-conscious production of a Chishtī historical tradition from the perspective of the colonial period. Nizām al-dīn's filial connections with Delhi and the last great 
phase of the Chishtiyya before $1274 / 1857$ had ensured his memorialization in texts often scarcely concerned with Awrangabad, the Deccan or even Sufism in general. As well as the Takmīla-ye-siyar al-awliyā of Gul Muhammad Ahmadpūrī and Sir Sayyid Ahmad Khān's Āthār al-sanād̄̄d, these also included Ghulām Sarwar Lāhawrī’s Khazīnat al-asfiyā. Beside Nizām al-dīn's proliferation into texts written in and about the cultural geography of North India, the saint also featured in the Deccan-based Urdu tadbkirāt of Imām al-dīn Naqwī and 'Abd al-Jabbār Khān Malkāpūrī along with the other Mughal saints of Awrangabad.

Just as the earlier literary commemoration of Awrangabad's saints by Bilgrāmī, Sabzawārī and 'Urūj sought to create a saintly heritage for the city in deference to the stately amour propre of the early Āsaf Jāh rulers, a similar process was underway in Haydarabad State during the first decades of the twentieth century. Fighting to re-assert its identity at the height of the colonial era, and having come to regard its mission as one of devotion to the protection of Islam in India, a new emphasis was given by a new generation of writers to the Muslim history of the Deccan in which the Sufis had played so large a part. The collective hagiographies of the Deccan's saints written at this time by Imām al-dīn Naqwī and 'Abd al-Jabbār Khān Malkāpūrī were thus part of the wider cultural programmes we have seen aimed at the preservation of either a pan-Islamic or specifically Deccani Muslim historical identity. Reflecting the wider struggle between localized and trans-regional expressions of Islam, these texts represented different visions of what it meant to be a Muslim in early twentieth-century India. While accepting Islam's presence in the Deccan without question, Naqwī and Malkāpūrī nonetheless differed in their sense of the religious importance granted to a specifically regional Muslim tradition, no less than to a more accommodating Islamicate tradition that could also incorporate Hindus within its fold. The two authors also differed in their understanding of the meaning and expression of Muslim sainthood. While Malkāpūrī was more amenable to repeating stories of the saints' miraculous deeds, Naqwī favoured an image of the saint primarily as instructor.

While reflecting wider cultural changes in Awrangabad at large, the Urdu tadhkirāt of the early twentieth century reveal much about the changing image of the city's saints and the changing fortunes of their shrines. This is seen most clearly with regard to the saints of Panchakkī, where the freshness of their early commemorative tradition in the writings of Shāh Mahmūd, Bilgrāmī and Sabzawārī was followed by a long silence unbroken until the early twentieth century with their description in Naqwì's Urdu Barakāt al-awliyā, devoted to a range of Sufis from all over the Deccan. Naqwī's description of Shāh Musāfir reveals how even the most standardized of literary images of the saints were subject to shifts over time, for in Naqwī's writing we see a reflection of the changing textual identity of Muslim sainthood en somme during the age of Islamic reform. Compared to the literary polish of Bilgrāmī's Persian, Naqwī's Urdu was purposeful and lacking in elegance. His text reflects a transformation of the tadbkira from what was often the pious belle-lettrism of a cultivated elite to a means of the dissemination of new ideas about Islam and its heritage formed for a readership with only functional literacy in Urdu. Placed within 
a new educationalist framework and targeting as wide an audience as possible, works such as Barakāt al-awliyā represented a distinctly twentieth-century form of hagiography. Shāh Musāfir's notice in the Barakāt al-awliyā thus begins with a formulaic description of the saint's most orthodox deeds, ever involved 'in divine remembrance, worship, dhikr and spiritual works'. The text then praises him as the founder of a centre of learning for shaykhs and 'ulama into which the image of his takiyya at Panchakkī had been transformed. ${ }^{67}$ Despite the shrine's varied history as the location of poetic inspiration, evening promenades and even the performance of dancing boys, Panchakkī here had its cultural functions narrowed to reflect the sober character of the madrasas we saw emerging at this time among North Indian Sufi groups in Chapter 3. The saint was here no longer the miracle-monger of Shāh Mahmūd's Malfüzāt-e-Naqshbandiyya, the possessor of terrifying and sometimes ambiguous powers. Gone were the militiamen and notables, the bhang and the bewilderment, of the saint's first literary incarnation to be replaced by an image of him as the headmaster of a seminary of bookish 'ulamā. Panchakkī was transformed into the very kind of environment to which Naqwī belonged.

Nonetheless, Naqwī placed great emphasis on the built presence of the shrine of Shāh Musāfir, quoting the chronogram written for the saint by Bilgrāmī and preserved on the tympanum of the saint's mausoleum. Standing out as the only distinguishing feature of Shāh Musāfir among the pious banalities of Naqwī’s text was the claim that Shāh Musāfir himself built the takiyya, mosque, khanaqah and pool at Awrangabad where he taught the city's shaykhs and 'ulamā. Naqwī showed no sign of having read the Malfüzāt-e-Naqshbandiyya. All that he knew about Shāh Musāfir - indeed the fact that he was known to Naqwī at all - was drawn from the presence of the saint's splendid shrine, whose existence he attributed to saintly rather than stately efforts. This impression is confirmed by Naqwī's appropriation without attribution of Bilgrāmī's chronogram of Shāh Musāfir's death, suggesting that Naqwī knew the verses from the inscription at the shrine without being aware of their noteworthy authorship. Here then was an interface between hagiography and the architecture of remembrance. For in the absence of a clear textual pedigree for the saint in earlier works known to Naqwī, Shāh Musāfir's inclusion in Barakāt al-awliyā seems to have come about solely due to the existence of his architectural legacy in Awrangabad, the description of which occupied more space and was more acutely observed than the references to the saint himself.

Insofar as Shāh Musāfir was remembered, it was due to the existence of his shrine of Panchakkī, which was in a sense the true entrant in Naqwì's text. Despite the remarkable individuality of Shāh Musāfir's life as described by Shāh Mahmūd, the saint found himself recast after the colonial and reformist image of the missionaryeducationalist. For by the early twentieth century, not only were individual saints being groomed for a new identity, but so was Muslim sainthood as a whole. This pattern of presenting the Sufis as teachers and preachers of Islam rather than as miracle workers would later be repeated in a variety of twentieth-century Indian works on the Sufis, most notably in those associated with the Sufi-inspired missionary organization, Tablīghī Jamā'‘at. ${ }^{68}$ 
The long literary silence in the tadbkira tradition of Shāh Nūr between the late eighteenth and early twentieth centuries mirrored the long chronological gap in the written memory of Shāh Musāfir. In the case of Shāh Nūr, the circumstances seem to be related to the long lapse in the cult's management by a sajjäda nashin in the nineteenth century prior to its early twentieth-century revival. In his Barakāt al-awliya , Naqwī also wrote a short notice on Shāh Nūr. Like that on the saints of Panchakkī, it heralded a new and less nuanced image of saintly identity than that seen in the earlier tadhkirāt of Sabzawārī and 'Urūj. In an expression of the unresolved struggle between Islamic and ethnic identity that has been so important in the social history of Islam in India, Naqwī was concerned more than anything else with Shāh Nūr's purportedly Arab genealogy. He thereby claimed that Shāh Nūr was born of the sayyids of the city of Hama in Syria and was also a descendant of the great early Sufi of Baghdad 'Abd al-Qādir Jīlān̄, here echoing if also strongly emphasizing certain tendencies in earlier tradition. ${ }^{69}$ Despite its brevity and simple prose, Naqwî̀s notice on Shāh Nūr encapsulated the distinct strands that would go on to define the identity of Shāh Nūr throughout the twentieth century and prove symptomatic of wider currents in Muslim saintly traditions right across India. For in Naqwī's presentation of Shāh Nūr as a generous hammām-owner who lived for more than three centuries, during which he was ever busy in prayer and learning, Shāh Nūr appears as a peculiar collage of remembered historical anecdote, cultic tradition and reformist veneer.

The account given of Shāh Nūr by Malkāpūrī is found in his exhaustive Tadbkira-ye-awliya-ye-dakan (1331/1912-13), a companion work to his parallel works on the poets and kings of the Deccan. ${ }^{70}$ Although Malkāpūrì’s account of Shāh Nūr diverged from that of 'Urūj over the matter of the saint's nickname and Sufi teacher, the greater part of the stories that he recounted drew upon 'Urūj as their main source. ${ }^{71}$ However, connections between the lives of the saints and the wider political and cultural life of the Deccan may also be seen in Malkāpūrī's text no less than in the works of Bilgrāmī a century and a half earlier. In his account of Shāh Nūr, Malkāpūrī was keen to explain the courtly connections of the saint's followers as well as to detail the literary achievements of Shāh Nūr and his successors. ${ }^{72}$ This literaryminded presentation of the circle around Shāh Nūr was cautiously aware of the reformist currents of the period, leading Malkāpūrī to present Shāh Nūr and his successors as teachers and scholars of the Quran and Hadīth as well as workers of extraordinary wonders. The allusions to the royal court in the text, and their concomitant of an Indo-Muslim social hierarchy within which the saints and their descendants mixed with notables and statesmen, reflected the social world to which Malkāpūrī belonged in Haydarabad. In such commemorative works, whether written in memory of the Deccan's saints, poets or kings, the connections between Āsaf Jāh Haydarabad and the old ways of the Mughals were never far beneath the surface. For if the Indo-Muslim tradition of kingship and the old social order it sustained had disappeared as a frame of reference in Muslim writings from North India, in the Deccan the survival of Haydarabad State allowed local patriots like Malkāpūrī the privilege of preserving a historical identity that remained unbroken from the glorious days of Islam in precolonial India. 
The bookish accomplishments attached to Shāh Nūr and his descendants were also important to Malkāpūrī and his audience. In his tadbkira a sense of mutual refinement was exchanged between author and reader, as seen in such tropes as his penchant for quoting direct speech and poetry in Persian and in his evocation of the imagery of the Urdu romance narrative in some of his colourful tales of the saints. Not only do these stylistic traits point towards the intended audience of his works - aimed no less than Bilgrāmı̄'s earlier tadbkirāt at an audience of learning and status - they are also suggestive of a specific vision of the Deccan's past. Perhaps unsurprisingly, Malkāpūrī chose not to recount the miracle of Shāh Nūr buried deep in an anthill far out in the jungle, despite its inclusion in the earlier text of 'Urūj, his main source. For Malkāpūrī's narrative presented a more mannered version of the Deccan's heritage as exclusively Persophone, lettered and, like Sir Walter Scott's medieval heroes, fashioned after the tastes of an emerging bookbuying bourgeoisie. Bilgrāmī's works had formed the written memory of a whole era's rulers, poets and saints, who sometimes featured alongside one another in the same texts. A century and a half later, Malkāpūrī strove to record the grandeur of a whole regional culture in his overlapping volumes on the Sufis, sultans and poets of the Deccan in his wider literary endeavour to create an encyclopedic written memorial of the Deccan's past.

Yet like earlier tadbkirāt, Malkāpūrìs narrative was also connected to a Deccani geography of shrines and the cult practices that brought them to life. A large part of his notice on Shāh Nūr discussed details of his shrine, including matters of its location, architectural features and income. The lavishness of the several death anniversaries regularly celebrated for Shāh Nūr and his sajjäda nashīns was also expressed as a matter of pride. ${ }^{73}$ In this respect, Malkāpūrìs work reflected the earlier saintly almanacs created in the city, serving as an erudite but nonetheless entertaining guidebook to the Sufi pilgrimage centres of the Āsaf Jāh realm. Yet echoes of the changing identity of the saints in an age of reform were no less present. For alongside his discussion of Shāh Nūr's shrine and its customary celebrations, Malkāpūrī was careful to present the first of Shāh Nūr's successors, Shihāb al-dīn, as the founder of a madrasa at the shrine. Not only a place of miracles, like Naqwī's image of Panchakkī the shrine of Shāh Nūr found new dimensions to its past as a source of instruction in Islamic law. ${ }^{74}$ In a case of a vision of the past outlining a programme in the present, the existence of this earlier madrasa also played a role in justifying the revival of the madrasa at the shrine by its reviver Shams al-dīn Chishtī in the period in which Malkāpūrī was writing. In this way, Malkāpūrī was able to eulogize the shrine's former days of learning under the benevolent guidance of its sajjäda nashinns. In doing so, he could praise the representatives of the old social order of the hierarchy of saintly representatives who - new committees notwithstanding - would continue to maintain the status of the saints and their shrines as long as Haydarabad State survived. However, amid the new tradition of Indo-British historiography, Shāh Nūr was also the only one of the Awrangabad saints to feature in T.W. Beale's mid-nineteenth century Oriental Biographical Dictionary, so finding a small measure of recognition outside the Indo-Islamic tradition. ${ }^{75}$ 


\section{Saints and kings in the Urdu hagiographies}

Given his rise in prestige during the nineteenth century, Nizām al-dīn featured more prominently than any of the other saints of Awrangabad in writings from this period. The championing of the claims to Nizām al-dīn of Delhi and other regions of northern India over those of Awrangabad was reflected again during this period in texts such as the Khazīnat al-asfiyā (c.1281/1864) of Ghulām Sarwar Lāhawrī. Again, it was Nizām al-dīn's position as broker between the great Chishtīs of Delhi, Kalīm Allāh and Fakhr al-dīn, that formed the focus of Ghulām Sarwar's account of Nizām al-dīn in a text that was primarily concerned with the saints of Punjab. ${ }^{76}$ The only other detail of interest in Khazinnat al-asfiya is a somewhat confused reification of the saint's relationship with Nizām al-Mulk. ${ }^{77}$ Despite its paucity of detail, the emphasis that Ghulām Sarwar's account gave to structured familial and initiatory relationships reflects an important pattern in the wider organization of Sufi thought and activity. Studies of the Muslim saints in other parts of the world, such as Aleppo, similarly show Muslim sainthood as socially embedded in prestigious state, family and initiatory relationships. Reflecting the success of Nizām al-dīn and the other saints of empire in Mughal Awrangabad, the major saints of modern Aleppo were drawn from elite families associated with Ottoman rule rather than with Aleppo's rich Muslim history prior to the Ottoman invasion. ${ }^{78}$

Echoing the fame that Nizām al-dīn had won in the north through the nineteenth century, in the century after the return of the saint's ancestors from Delhi to Awrangabad his status in the Deccan similarly increased. The association of Nizām al-dīn with Nizām al-Mulk that was mentioned in the Khazīnat al-asfīya and the earlier writings of Sabzawārī and 'Imād al-Mulk blossomed in the Deccan into a series of more fulsome narratives. Drawing probably on an oral tradition that had gradually developed since Nizām al-dīn's death, the name and person of Nizām al-dīn came to be seen as the supernatural founder of the royal house of the Āsaf Jāhs and so in turn of the territorial integrity of the Haydarabad Deccan. These developments are seen clearly in the notices on Nizām al-dīn in the tadhkirāt of Naqwī and Malkāpūrī.

Both memorialists referred to the saint as a descendant of the major early Sufi, Shihāb al-dīn Suhrawardī (d. 632/1234). Although this genealogy was not new, given the links being built up between saint and state it is difficult not to see Nizām al-dīn's pedigree as in some degree a reflection of the official genealogy of the Āsaf Jāh rulers, who likewise claimed family descent from Suhrawardī. ${ }^{79}$ This saintly genealogy may be seen as adding historical depth to the close links cultivated between the successors of Nizām al-dīn and the representatives of the Āsaf Jāh state, tying royal and saintly families together into the distant past in a similar way to 'Imād al-Mulk's earlier writings on Fakhr al-dīn. Yet like Shāh Nūr's prestigious hagiographical genealogy of Arabian birth and descent, that of the Indian-born Nizām al-dīn and his royal follower also testified to the continuum between sanctity, authority and (perceptions of) ethnicity in Indo-Muslim societies.

For his part, Naqwī spent the greater part of his description of Nizām al-dīn in recounting a series of minor but symbolic events relating to the saint's time in the 
khanaqah of Kalīm Allāh in Delhi. He carefully presented the source of Nizām al-dīn's authority as bearer of the mantle (khirqa) and teaching licence (ijāza) given to him by Kalīm Allāh, before describing how the latter then granted the Deccan to his student as his own zone of spiritual authority (walāyat). ${ }^{80}$ What is striking about this formulation is the manner in which it outlines Sufi authority after the form of its political counterpart. For just as it had been the emperor in Delhi who had granted control of the Deccan to his own subordinate Nizām al-Mulk, so was Nizām al-dīn granted control of the Deccan from his master in Delhi. Formulations of saintly and royal legitimacy in the Deccan were thus made to mirror one another, through being based in the older and more legitimate sources of authority of the emperors and saints of Delhi. Over two centuries after the original Mughal conquest of the Deccan and the cultural changes that accompanied it, we see in Naqwìs narrative a twentieth-century version of the same process of the re-writing of the Deccan's cultural and political geography seen during the era of Mughal colonization.

As in his other notices on the Awrangabad saints, Naqwī also emphasized the role of Nizām al-dīn as a teacher. A smaller dose of the reformist re-definition of Sufism was felt in Malkāpūrī's presentation of the saint. ${ }^{81}$ Although Malkāpūrī drew in places upon the Absan al-shamā'il of Kāmgār Khān, there was also a new emphasis on the conversion of Hindus that was quite alien to the spirit of the earlier work. ${ }^{82}$ While the Absan al-shama'il contained several references to the Yogi followers of Nizām al-dīn, there was no sense that the saint's task was to convert them. In one long narrative in which a Hindu devotee wished to become a Muslim, Nizām al-dīn made it quite clear that he did not see it as his role to convert people. Instead, the Yogi had to resort to the khatīb of the city's Friday mosque in order to fulfil what was clearly his own wish of accepting Islam. ${ }^{83}$ With admirable prescience, Nizām al-dīn remarked in the Absan al-shama'il that converting people would only make others afraid. It was also in a spirit of contrast to the Absan al-shamä'il that in an otherwise charming narrative drawing on the tradition of the Urdu romantic mathnaw $\bar{\imath}$, Malkāpūrī described how one of the followers of Nizām al-dīn fell in love with a beautiful female Yogi (jōgin), who spent her days on a swing surrounded by 500 followers. ${ }^{84}$ With the saint's help, the final outcome of this romantic entanglement was the mass conversion of the band of Yogi followers, followed by the happy marriage of the former $\bar{j} \bar{g}$ in to Nizām al-dīn's follower. This emphasis on conversion echoed the broader movement of Islamic revival that we have seen in Haydarabad State during this period, in which Muslim and Hindu groups competed for the religious loyalties of the people of the state. Nonetheless, Malkāpūrī was sensitive to the wider cultural traditions of the Deccan, and like other picturesque elements of his writings the joggin story also served to add an element of local colour. For his text was more truly a celebration of a specifically Deccani Muslim culture than of a deracinated universal Islam. As a native of the northern Deccan region of Berar, Malkāpūrī in such ways echoed the mulkī sentiments of the Haydarabadi nationalists.

Malkāpūrī also gave voice to a new bureaucratic dimension to sainthood that was emerging in this period of the modernizing of state and religious organizations. In a 
series of startling images, Malkāpūrī described how Nizām al-dīn enjoyed helping the poor through writing letters of recommendation to the rich, while dealing with the pleas of his clients through the use of paper warrants and an official seal (mubr) given to him by Nizām al-Mulk. ${ }^{85}$ So many people came to ask for their requests to be officially stamped that the saint decided to hang the seal outside the door of his cell, so allowing the poor to draw promissory notes on the state treasury at their own questionable discretion. ${ }^{86}$ Needless to say, the plan came to no good and Nizām al-Mulk begged the saint to discontinue the practice. These bureaucratic images fit into the wider narrative association of the saint with Nizām al-Mulk which plays a central part in Malkāpūrī's account. Alongside descriptions of the ruler's devotion to the saint, Malkāpūrī recounted the influential tradition of how Nizām al-dīn miraculously intervened to help Nizām al-Mulk defeat his rival Mubāriz Khān in battle at Shakar Khera in 1137/1724, an event generally regarded as having laid the foundation of Āsaf Jāh rule in the Deccan. ${ }^{87}$ As we have seen, an earlier version of this story had already been presented in the nineteenth-century Mishkat al-Nubuwwat of Ghulām 'Alī Qādirī of Haydarabad. According to Malkāpūrī's version, the saint was already present in the army of Nizām al-Mulk and promised the latter signs of victory after he came to beg the saint for help. Shortly afterwards, a series of sandalwood handprints mysteriously appeared on the tents of Nizām al-Mulk's soldiers, protecting their occupants and prophesying their victory. The symbolism of the sandal handprint acting as a protective talisman drew on the custom during the saints' death anniversaries of placing red handprints on the walls of the shrine after the sandalmali ritual of daubing the saint's tomb with crimson sandalwood paste. Once again the tales of the saints were connected to the ritual practices associated with their shrines. In Malkāpūrī's narrative, Nizām al-dīn is thus seen as the supernatural patron of Haydarabad's founder and in a sense as the state's secret and eponymous founder in reflection of a tradition probably well-known to many of Malkāpūrī's readers. Yet as in all such narrative associations of saints and kings, the ruler won legitimacy for the actions he carried out by saintly decree.

In the context of his other writings, Malkāpūrîs narrative of the saintly sponsorship of Haydarabad's foundation was predictable enough. He also recounted the same story at greater length in his history of the Deccan's kings. Here was a distinct form of regional nationalism that was engendered through a local historical tradition of a saint giving miraculous rise to an independent polity. By the time of the writing of Malkāpūrī's text, Nizām al-Mulk's successor state had lasted for almost two centuries while many of its early contemporaries - Awadh, Arkat, Maysur - had long since fallen to the British. Such narratives of the saintly patronage of kingdoms, though well attested in the premodern historiography of Muslim India, continued to be of importance in the early twentieth century. Despite the reformist image of the Sufi as missionary and teacher, in such cases the saints continued to control the destiny of whole nations.

More fortunate in hagiographical terms than any of the Awrangabad saints during this period were the earlier Sufi saints of nearby Khuldabad. For all of the evident revival of their cults, the Awrangabad saints had to satisfy themselves with a mention in the 
pan-Deccan hagiographies of Malkāpūrī and Naqwī, while the Khuldabad Sufis were celebrated in two new Urdu hagiographies devoted entirely to Khuldabad. These works were the Rawzat al-aqtāb of Mawlwī Rawnaq 'Alī and the Rawza-ye-sharîf of the Nizām's Hindu prime minister, Kishan Parshād. ${ }^{88}$ These two works originally appeared in the early 1930s. In contrast to the aristocratic background of Kishan Parshād, Rawnaq 'Alī was a local schoolteacher, whose book was clearly related to the ongoing popularity of Khuldabad as a pilgrimage destination. Indeed, with its wealth of architectural and historical detail, Rawzat al-aqtāb was in many ways a species of superior guidebook and as such a worthy heir to Sabzawārī's earlier Sawānih. The book was first published in 1349/1931 in Lucknow, where the author had family connections, but was later republished several times in Awrangabad.

Rawzat al-aqtāb is a lengthy work that is devoted not only to the saints of Khuldabad but also to the rulers, notables and poets buried there. Like Malkāpūrī a decade or two earlier, Rawnaq 'Alī drew on a large number of manuscript sources and his work is of historical no less than hagiographical value. In many ways, Rawzat al-aqtāb was a hybrid text, symptomatic of the evolution of the Islamic hagiography in new stylistic and intellectual directions. One the one hand, the work deliberately echoed the earlier structure (and title) of Bilgrāmī's Rawzat al-awliyā, while also reflecting such nineteenth-century works as the $\bar{A} t h \bar{a} r$ al-sanād $\bar{\imath} d$ of Sayyid Ahmad Khān in its cataloguing of the architecture no less than the personalities of a given urban habitat. But on the other hand it also resembled the more recent imperial genre of the gazetteer in its attention to the facts and figures of the town's population and number of residences. ${ }^{89}$ The numbers of the various kinds of servants (khuddām) at the shrines and their expenses were similarly presented in tabulated form. ${ }^{90}$ From this we learn that along with a whole host of more menial attendants, in the early 1930s there were still forty Quran and prayer recitors (bufāz wa salwāt kbwān) employed in Khuldabad. A range of other people devoted their working lives to further rituals associated with pilgrimage to the shrines. These included vendors of flowers, incense (agarbat $\bar{\imath})$ and candles, as well as prayer-makers $\left(d u^{\prime} \bar{a} g \bar{u}\right)$. Four mace-bearers ( $c h \bar{u} b d \bar{a} r$ ) were assigned to ceremonially guard the tomb of Awrangzeb, which in 1341/1922 had been partitioned by marble lattice screens through the joint efforts of Lord Curzon and Nizām 'Uthmān 'Alī Khān. A section on the clothing and manners (labās wa akhlāq) of Khuldabad's residents brought the earlier tradition of the urban encomium into line with more modern ethnographic interests. Its account of the jackets and turbans sported by the men of the holy town contained references to the new imperial geography of Bombay and Shimla. ${ }^{91}$ Space was also given in the text to the ancient Buddhist and Hindu monuments at the foot of the Khuldabad hillside and to a picturesque account of the Hindu customs associated with the water tank (kund) there. ${ }^{92}$

Nonetheless, Rawzat al-aqtāb was primarily a work devoted to upholding the memory of the saints and kings buried in Khuldabad, and as such the greater part of the text is devoted to the large number of Sufis and notables interred there. The author was careful to bring a certain academic rigour to his presentation of these figures, and his accounts of the saints are notable for their abundant use of the Sufis' 
early collections of 'recorded conversations' (malfūz $\bar{a} t$ ). Yet alongside the descriptions of the architecture of the saintly shrines and the rituals associated with them was a corresponding degree of attention to the burials of such notable figures as Nizām al-Mulk and his assassinated son, Nāsir Jang, now designated as a 'martyr' (shahīd). ${ }^{93}$ In the first half of the twentieth century the saints and kings of the Deccan thus seemed inseparable in the works of such writers as Malkāpūrī and Rawnaq 'Alī. Perhaps there was nothing remarkable about this, for despite the enormous social changes in evidence throughout British India, for many of its people the Haydarabad Deccan remained a feudal society that maintained many of the traditions of the Mughal age. Evident in the writings from this period is the survival - however tenuous - of a political and moral order that was still structured with reference to the Nizām and his saintly counterparts, the aqtāb or 'axes' of the cosmos summoned in the title of Rawnaq 'Alī's book. 


\section{THE AWRANGABAD SAINTS IN THE NEW INDIA}

His followers have special faith in him and he was very good in the knowledge of spiritual wayfaring and Sufism ('ilm-e-sulük wa tasawwuf), especially in the arts of Mathnawi-reading and Mathnawīknowing (mathnawīkbān̄̄ wa mathnawīdān̄ì). ${ }^{1}$

\section{From Haydarabad to Mother India}

From the era of Awrangabad's Mughal Sufis through the establishment of the Āsaf Jāh dynasty and the consequences of the Great Revolt, Haydarabad's independence rendered her Muslims able to partially avoid the colonial disenfranchisement of Islam in India. As in other princely states, British influence did gradually increase from the second half of the nineteenth century onwards. But Haydarabad was able to uphold Muslim prestige through an official maintenance of Muslims in positions of influence and a plethora of the individual acts of patronage that a Muslim landowning class made possible. For despite the nineteenth-century reforms of the prime minister Sālār Jang, Haydarabad effectively maintained a feudal system of vast aristocratic landholdings. While Muslims were not the sole landowners in the state, their strong presence among not only the landholding class but also the civil service and the army gave them undoubted privileges over the far larger Hindu population of the state, even if there were Hindus in the aristocracy and government. All this served to encourage the Muslims' dependence on the state, just as Hindu domination of Haydarabad's trade rendered certain caste communities more independent of it. When the swift dissolution of Haydarabad came about in 1367/1948, its consequences were therefore felt keenly by its Muslim population. ${ }^{2}$

None of this is to say that Haydarabadi Hindus did not identify with the state, or with the composite Islamicate culture of the Deccan within which Hindus had for centuries adapted elements of Islamic tradition for their own purposes. But the drive towards independence, and the emergence of the religious nationalisms that accompanied it, meant that much common ground between Muslims and Hindus was lost. As India's independence became increasingly likely during the 1930 s and 1940 s, the anomaly of Haydarabad's position became starkly apparent. Its very existence became a symbol for competing versions of India's identity and political 
destiny, with opposing rhetoric painting Haydarabad either as a symbol of Hindu oppression or a final bastion of Muslim independence.

During the 1920s and 1930s, religious approaches towards these questions of collective identity increasingly found political expression. The years leading up to India's independence witnessed the growing influence of religious nationalism among Hindus in the Central Provinces on Haydarabad's northern borders and among the Marathispeaking Hindus of the Bombay Presidency and the western part of Haydarabad State. Some Hindu revivalist organizations went as far as to adopt paramilitary methods for the supposed defence of their faith. Reflecting them, the very last years before India's independence saw a similar paramilitary wing emerge from Haydarabad's Council for Muslim Unity (Majlis-e-Ittihād al-Muslimīn) known as the razākārs or 'volunteers'. Devoted to 'protecting' Haydarabad's Muslims from the threat of Hindu domination, the razākārs soon fell into terrorizing considerable sections of Haydarabad's Hindu population, particularly in rural areas close to the state's borders that were suspected of complicity in smuggling Congress activists into Haydarabad. The region surrounding Awrangabad was one of several centres of razäkār activity.

The most contentious issue surrounding Haydarabad's surrender to rule by a united and independent India is that of the alleged massacres of Muslims that accompanied the 'police action' of Haydarabad's invasion by Nehru's new national army in $1367 / 1948 .{ }^{3}$ While it is difficult to assess the genuine scale of the disaster, it is clear that many Hindus did turn upon their Muslim neighbours in a series of local pogroms throughout the state. In some cases, Sufi shrines and mosques were demolished or turned into temples. The great Bahmani period mosque at Dawlatabad (itself possibly built from temple spolia) was the most famous place of Muslim worship to be turned into a Hindu temple. ${ }^{4}$ Still, as they had for centuries, the saints were resorted to for protection in this period of calamity. In Gulbarga, political observers claimed that up to nine thousand rural Muslims sought sanctuary in the shrine of Gēsū Darāz, before being sent back to their villages. ${ }^{5}$ Other enforced population movements were also in progress. While the Deccan had for centuries maintained close contact with the Arabian peninsular, thousands of Hadrāmī Arabs resident in Haydarabad who could not claim parental or marital links to India were deported en masse to Aden. ${ }^{6}$ The Arabian city in the centre of India of laden camels and women in burqas described by the British traveller Wilfrid Scawen Blunt in the early years of the twentieth century was rapidly transformed. And so the face of Haydarabad began to change within hours of the official surrender of its forces by the Nizām's Hadrāmī commander-in-chief. In a move celebrated by modernizers and bewailed by the old elite, in 1949 the Government of India passed the Jagirdari Abolition Act that heralded the final end of Haydarabad's old order. Here was the dismantling of the feudal landholding system that had maintained the Deccan's Muslim status quo in all manner of ways, from giving the direct income of properties to presenting rich offerings to the sajjäda nashīn families of Sufi shrines. ${ }^{7}$ The reform of the laws on Muslim charitable endowments (awqāf) had a comparable effect on the wealth and power of Sufi shrines to the earlier erosion of Muslim landholdings in regions under British control. ${ }^{8}$ 
In Awrangabad, as in other urban centres in the former dominions of the Nizām, the decades after 1948 also saw a tremendous growth in population. Migration was encouraged by possibilities of commercial investment, attracting members of certain communities (Marwaris and Punjabis in particular) associated with trade. With the shock of the swift impoverishment of scores of old families, Awrangabad's Muslims were slow or financially unable to capitalize on the industrialization of their city in the 1960s and 1970s, when industrial incentives were given for companies to relocate to Awrangabad as a result of the union of the city with Bombay into the new state of Maharashtra in 1956. In the decades after 1948, what had been the second city of an independent state dominated by Muslims thus witnessed the relative impoverishment of its Muslim citizens. But the expansion of educational opportunities offered by the new government and the possibility of work in the Persian Gulf meant that a Muslim middle class did slowly develop in the city in the decades after Haydarabad's dissolution. But the cultural changes that inevitably accompanied Haydarabad's transition meant that financial impoverishment seemed for many Muslims to be accompanied by a parallel cultural disenfranchisement. ${ }^{9}$ Awrangabad's detachment from the city of Haydarabad in 1956 with its absorption by the new state of Maharashtra seemed for many to symbolize this, with Urdu's loss of influence to Marathi felt keenly in a city that had played so central a role in the history of Urdu. Where economic and cultural change coincided in so short a period, religious change was quick to follow. As in other regions of India and Pakistan, the second half of the twentieth century saw the continued spread of Muslim reformist movements, whose stripped-down versions of the faith bear many of the hallmarks of the transition to modernity. From the 1970s such reformist approaches to Islam, shunning hope of the miraculous intercession of the Sufi saints and the veneration of their shrines, were bolstered by the influence of migrant workers travelling between their family homes in Awrangabad and their places of employment in Saudi Arabia and the Gulf States.

\section{The Awrangabad saints in the Indian nation}

\section{Shāh Nūr}

While the arrival of Shams al-dīn in Awrangabad at the turn of the twentieth century had caused a successful revival in the cult of Shāh Nūr, Shams al-dīn never enjoyed the financial independence of the city's other sajjäda nashinns. The earlier decline of Shāh Nūr's shrine had led to the gradual loss of the landholdings belonging to it and Shams al-dīn's solution had been to involve government officials in the shrine's administration. His follower Faz̄̄lat Jang, the Nizām's Minister for Religious Affairs (umūr-e-madhhabì), became responsible for overseeing the appointment of an administrator (mutawal $\bar{l})$ at the shrine. While the involvement of the state in the shrine's affairs still left Shams al-din to run the shrine on a day-to-day level, it also helped ease the financial situation by allowing the shrine to reclaim some of the income of its former landholdings. But when Shams al-dīn died during one of his regular pilgrimages to the shrine of $\mathrm{Mu}^{\prime} \mathbf{i} n$ al-dīn Chishtī at Ajmer in 1347/1928, a dispute 


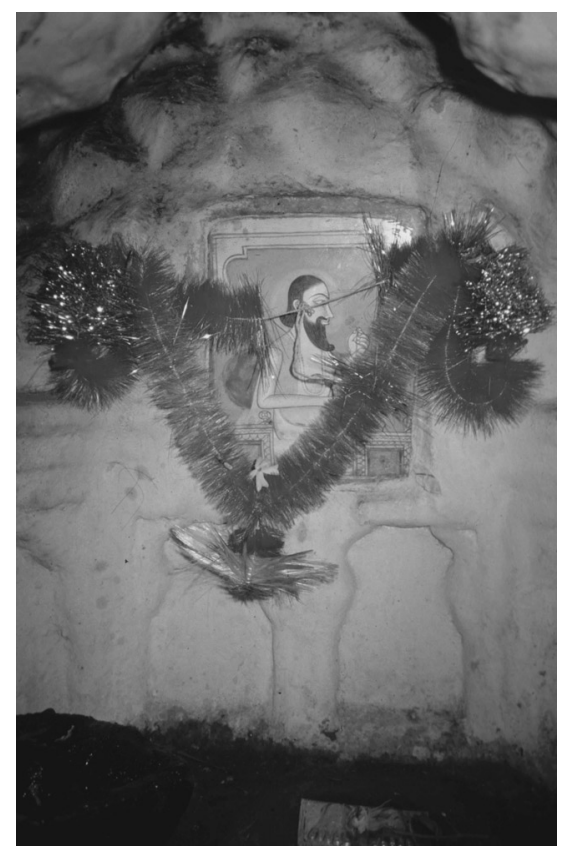

Figure 5.1 Miniature painting of Shāh Nūr at the math of Mānpūrī in Dawlatabad.

arose over the future management of the shrine that would continue for the remainder of the century. While there were personal dimensions to the dispute, including petty rivalries between a new Muslim middle class in Awrangabad and the respectable families of old, the dispute was in essence a structural one. As such, it reflected debates that had existed in the Sufi tradition for centuries about the right to inherit the charisma of a deceased master via ties of either blood or initiation. Modernizing trends in the administration of Haydarabad had meant that by the early twentieth century these old debates were being trumped by the emergence of rule by committee. Given the role of the government in the shrine's administration under Shams al-dīn, it was therefore only a small step to replace him after his death with an eight-member management committee. ${ }^{10}$

In the decades after Shams al-din's death, the day-to-day administration of the shrine remained in the hands of a series of management committees. The first of these committees came under the auspices of the Awrangabad Tehsil Office during the reign of the last Nizām, while after 1367/1948 its successor was appointed by the Muslim Waqf Board (later the Marathwada Waqf Board). Despite this, problems continued to arise in the shrine's administration, particularly with regard to the performance of the saint's death anniversary that was the most important but financially demanding event of the year. Though it is unclear what the precise problems with the early post-dissolution committees were, it seems likely that they underwent the 
same difficulties as other Muslim institutions in the former state after the removal of the support of the Nizām and his administration. As a consequence, a new management committee came into being in 1392/1972 that was composed solely of local residents of the quarter of the city now known as Othmanpura quarter in which the shrine was located. Drawn away from the hands of disinterested bureaucrats, the new committee was composed of local Muslim businessmen keen to make a mark on their community. Here was a new form of patronage of the saints. The local businessmen who now managed the committee were generous in their provision of funds for the 'urs and from the 1970s the shrine became noted for the abundance and quality of the feasts (langar) served freely to anyone who attended the week-long anniversary of the saint's death. The owner of a successful local betel nut business was prominent in the committee and oversaw the collection of funds for repairs to the shrine buildings. During the mid-1970s, these included the repair of the feasting hall (langarkhanna), the mosque roof and several more general programmes of embellishment. ${ }^{11}$ A library and an elementary school with links to the shrine were also established at this time. The rising influence of the merchant classes also brought with it symptoms of wider religious change and in 1393/1973 a new madrasa was established, funded by local donations administered by the committee. ${ }^{12}$ The religious teachers (mawlwiss) at this madrasa drew on the doctrines of the Barēwlī movement, which sought to find a place for elements of traditional Sufi devotionalism within a wider movement towards religious reform. But in practice its representatives in Awrangabad were far from sympathetic towards many of the beliefs and practices associated with the shrine of Shāh Nūr. ${ }^{13}$ Seeing their role as expressly one of the reform of a shrine attracting a large population of Hindu as well as Muslim pilgrims, by the 1980s the mawlwis came into competition with other versions of Shāh Nūr's heritage and with the persons who claimed to represent it.

Quietly competing with the representatives of the madrasa were several individuals claiming to be the sajjāda nashinns of Shāh Nūr. Divided among themselves, both of the sajjäda nashin lineages at the shrine traced themselves to Shams al-dīn. Through his marriage to a daughter of the sajjāda nashīn of Nizām al-dīn, Sayf al-dīn, Shams al-dīn had a son, who was later known as Banē Miyān. ${ }^{14}$ Born and brought up in Awrangabad, Banē Miyān was considered a religious teacher like his father and sought to widen his circle of followers by travelling widely throughout the Deccan. ${ }^{15}$ In reflection of his claim to have inherited his father's connection to Shāh Nūr, Banē Miyān continued to live at the shrine throughout his entire life. His family claim to the shrine was symbolically upheld by the burial of his father Shams al-dīn right next to the main mausoleum of Shāh Nūr. Cementing the claim that the shrine was now not only the sacred territory of Shāh Nūr but also that of the new saint, Shams al-dīn, during the 1960s a smaller domed mausoleum was constructed over Shams al-dinn's grave. Banē Miyān was therefore able to present himself as not only sajjäda nashīn of Shāh Nūr but also of Shams al-dīn. But while Banē Miyān continued to live at the shrine, his authority over it was disputed. In a reflection of the old Sufi rivalry between ties of blood and initiation, a Haydarabadi disciple of Shams al-dīn known to his own followers as Allāh kē Hukam also claimed to be Shams al-dīn's true 
successor. After Allāh kē Hukam's death in the early 1980s, a rival lineage based in Haydarabad emerged that was led by his own son, Sayyid Wāsil. Devotees from this line continued to regularly attend the conflated 'urs of Shāh Nūr and Shams al-dīn in Awrangabad, annually manifesting the claims of Allāh kē Hukam's lineage as the true spiritual heirs of Shāh Nūr.

However, as is the case at hundreds of Sufi shrines throughout India and Pakistan, still further claimants emerged to the saint's authority and the revenues of shrine custodian that came with it. Banē Miyān had married an Anglo-Indian (and so presumably Christian) woman, whose father had worked on the railways like so many other Anglo-Indians. Upon his death, Banē Miyān's own inheritance was disputed between his son and one of his disciples, Khwāja Muhȳi al-dīn Shamsī of Haydarabad. While Banē Miyān's son continued to live at the shrine, where he attended to the 'urs of his father and taught a small circle of followers, he was marginalized by many of the shrine's devotees. In the late 1980s, another disciple of Banē Miyān took over one of the old dervish chambers at the shrine. Free of the controversy surrounding the claimants to the position of sajjäda nashīn, for the remainder of the twentieth century Mīrzā Ibrāhīm spent his days in his retreat at the shrine receiving visitors anxious about exams, the sickness of loved ones or occasionally those concerned with more explicitly religious matters. In line with what he presented as the teachings of his master, Mīrzā Ibrāhīm promised only to pray for these supplicants for the mercy of God and his friend, Shāh Nūr.

Despite (or even because of) these different sources of spiritual authority and practical leadership, the shrine continued to flourish in the decades after Haydarabad's dissolution. As in the eighteenth century when Sabzawārī described the shrine as being visited by all classes and kinds of people, at the end of the twentieth century Shāh Nūr attracted far more regular visitors than any other Sufi saint in the city. As Sabzawārī had earlier described him, he was

a qalandar without equal, an enlightened (rüshan zamīr) dervish, a roc (sīmūrgh) on Mount Qāf, a holy hawk in the space of divine intimacy, who was always busy in the remembrance of the Truth and was among the faqiers and great ones of the Sufi path (tariqat). ${ }^{16}$

The visitors to the shrine also reflected the different notions of Shāh Nūr's identity that had developed over the centuries since his death. For many followers, both Hindu and Muslim, Shāh Nūr remained above all the gentle but powerful holy man summed up in the religiously non-denominational term of rabmān $\bar{\imath} b \bar{a} b \bar{a}$ or 'compassionate elder'. In oral tradition, this image took on local shape as Shāh Nūr was described in one famous legend as sitting for decades in meditation in the forests outside the city. Here he became covered with an anthill that gradually grew over him, an echo of the story of the Hindu sage Valmīki and local Hindu figures in Maharashtra. For other followers, however, particularly those influenced by reformist interpretations of the role of the Sufis, Shāh Nūr was believed to have come to India from Baghdad on a religious 'mission' (Urdu mishan) to convert local Hindus from 
idolatry to worship of the single God of Islam. Many devotees of the saint in the late twentieth century found themselves caught between these two conflicting interpretations of the purpose of the Sufis. When one of the students or mullahs (mawlwiss) from the neighbouring madrasa came into the shrine, devotees' behaviour would be subtly modified. Pilgrims would avoid kissing the tomb, while women would quickly cover their heads; the shrine attendants (khädims) would become less ceremonious in doffing the pilgrims' heads with the peacock feather fan (mōrchbal) kept beside the saint's tomb. During the performance of Shāh Nūr's death anniversary, the mawlwis regularly attempted to co-opt the rituals towards their own version of the purpose of popular Muslim piety, chanting loud praise songs (durūd) to the Prophet Muhammad throughout the parts of the ritual they found distasteful. At one such event in the 1990s, their yelling almost led devotees to abandon the ritual washing of Shāh Nūr's tomb in frustration. However, the close connections between the madrasa and the shrine committee meant that neither ordinary devotees nor the servants and sajjäda nashins dependent on the committee's goodwill dared criticize the mawlwīs or their students openly.

In the absence of these representatives of Barēlwi reform, the shrine continued many of its old traditions. Hindu and Muslim devotees were brought together in common devotion to the saint, many of them making a point of the love between Shāh Nūr and his Hindu companion, Mānpūrī. In the ritual etiquette of devotion at the shrine, the cult of Shāh Nūr managed to preserve much of the earlier composite culture that had developed in the Deccan during centuries of Muslim and Hindu co-existence. This legacy was also bolstered by the presence of two tombs at the shrine that were regarded as belonging to two of the saint's other Hindu followers. One of these tombs lay in a special courtyard of its own on the north side of the shrine and both were regularly garlanded with flowers. In 1424/2003, a special issue of the Urdu journal Awliyā Allāh was devoted to the tradition of Shāh Nūr. Compiled by the local literary historian Mīrzā Āghā Bēg and the local Sufi Muhammad Mazhar Nizāmī, the publication consisted mainly of photographic images of the sites associated with Shāh Nūr around Awrangabad, along with brief descriptions of their history. While handing on the memory of the Mughal associations of Shāh Nūr, the authors also took trouble to bring their readers' attention to the close connection between Shāh Nūr and Mānpūrī. ${ }^{17}$

Reflecting this tradition of friendship between Sufi and Sadhu, the shrine of Shāh Nūr maintained a particularly close connection with Hindus from the village of Satara outside Awrangabad. In the village oral traditions spoke of the saint's appearance on the surrounding hills at night, as though quietly protecting the village's population as they slept. The new connections established by Shams al-dinn with parties in Haydarabad earlier in the century continued to be important through the work there of his son Banē Miyān's disciple, Muhȳi al-dīn. As a result, scores of Haydarabadi pilgrims continued to attend the death anniversary of Shāh Nūr every year. With the fairground, trinket stalls and makeshift tea-shops that appeared outside the shrine during the week-long celebrations, the shrine had a joyful atmosphere during these festivities each year. Along with the musical sessions of qawwāt 


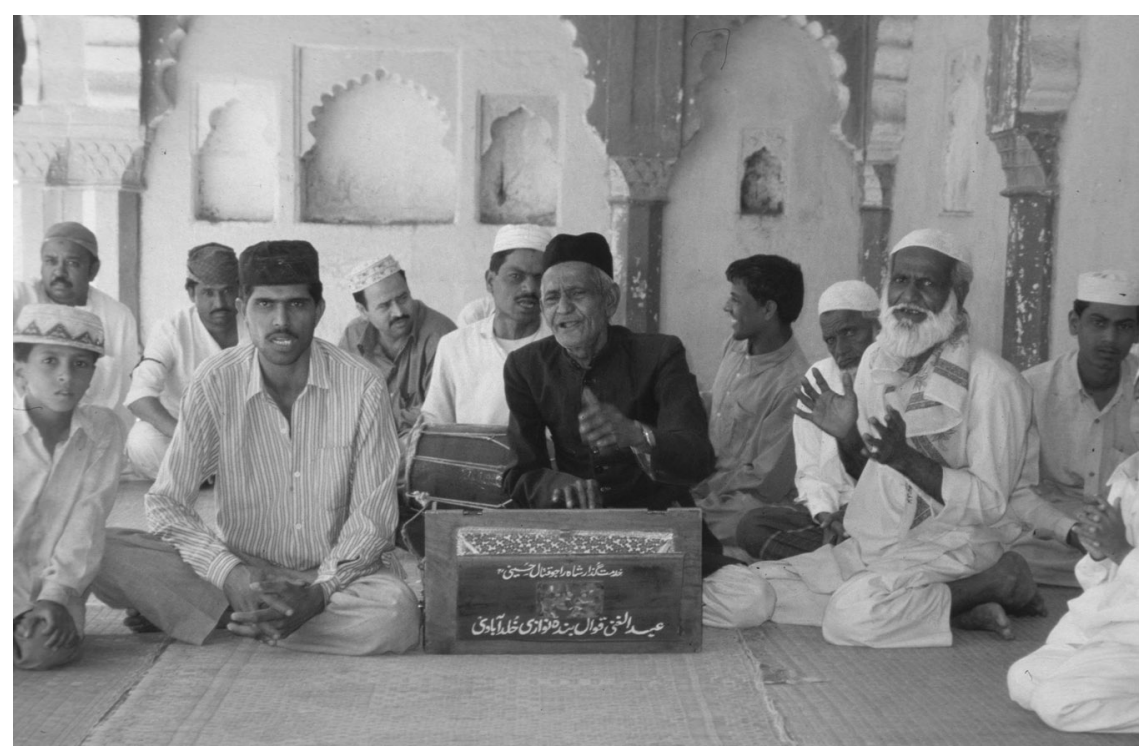

Figure 5.2 Sufi musicians singing qawwāl̄̄ at Khuldabad.

that Shams al-din had introduced at the beginning of the century, these attractions combined with the allure of the gentle rabmann $\bar{\imath} b \bar{a} b \bar{a}$ himself to call several thousand pilgrims to the festival each year. Reflecting the association of the sübedārs of Awrangabad with the shrine earlier in the century, in recent times as the chief local representative of the state, the city's commissioner, continued the custom of attending the opening ceremony of Shāh Nūr's death anniversary. Just as the saint's ties to the Mughal and Āsaf Jāh state had been a source of pride for earlier generations of devotees, Shāh Nūr's association with the representatives of the Indian government continued to be important for many of the saint's followers at the end of the twentieth century.

\section{The saints of Panchakki}

When Ghulām Mahmūd, the last direct descendant of Shāh Musāfir's first sajjāda nashīn Shāh Mahmūd, died without issue in 1339/1920 the property and landholdings of the shrine fell into the hands of Haydarabad's Department of Religious Endowments as his widows failed to maintain control over them. However, saintly traditions rarely die out overnight and the termination of Ghulām Mahmūd's lineage was disputed by other relatives. In the years after the death of Ghulām Mahmūd's two widows, an indirect descendant of Ghulām Mahmūd came forward to continue the tradition of the sajjāda nashīns. Ghulām Mahmūd's second wife Sāliha Bēgam had eventually appointed this nephew, Yūsuf al-dīn Maghribī, to act as sajjāda nashīn of the shrine when he 
reached adulthood. ${ }^{18}$ If this was by no means a conventional mode of appointment, it demonstrated the flexibility of tradition and the sometimes influential role women play in cult life. While Yūsuf al-dīn was never recognized by the state government and so never achieved the restoration of landholdings that would come with it (or, after Haydarabad's abolition, a stipend based upon them), he nonetheless remained resident at Panchakkī with his family until his death in 1414/1994. As a sajjāda nashīn with no absolute claim to legitimacy from either bloodline or state, his position was therefore similar to that of Banē Miyān at the shrine of Shāh Nūr.

Much of the shrine's land had been surrendered to the state and the shrine was no longer the great landowner it had been during its economic heyday in the eighteenth and nineteenth centuries. But Yūsuf al-dīn still managed to acquire a handsome income from the shrine, which was augmented by a number of shrewd local investments that paid off with the city's commercial development during the 1960s and 1970s. Subsequently, Yūsuf al-dīn was able to live out the leisured lifestyle that his ancestors had themselves been accustomed to as sajjäda nashins, devoting his time to such gentlemanly pursuits as maintaining the shrine's splendid gardens and aiding in the compilation of works on Awrangabad's history. He granted a number of scholars access to what remained of Panchakkî's library, aiding the local historians Shaykh Ramazān and Mubāriz al-dīn Raf'at. The latter compiled an Urdu history of the shrine entitled simply Panchakki-ye-Awrangāba $d$, largely based on the Malfüzāt-e-Naqshbandiyya but also including useful information on the more recent history of the shrine. ${ }^{19}$ Yùsuf al-dīn himself wrote and self-published a small work of his own in English, entitled Aurangabad's Old Water Supply System of Aqueducts. ${ }^{20}$ Reflecting the antiquarian interests of a local circle of Muslim scholars and dilettantes educated in both Urdu and English, Yūsuf al-dīn's work studied the underground irrigation channels (nehrs) which Awrangabad had possessed since the time of Malik 'Anbar. Special attention was given to the Panchakkī nehr, while the booklet as a whole was dedicated to Yūsuf al-dīn's ancestor Shāh Mahmūd, the author of the Malfüzāt-e-Naqshbandiyya.

Aside from his scholarly and horticultural interests, Yūsuf al-dīn was also known in the city for his grand lifestyle. He seems to have been one of the first people in Awrangabad to own a motor car, while also enjoying a certain renown for his conviviality. Nonetheless, Yūsuf al-dīn took his duties seriously as heir to the traditions of Shāh Musāfir and while few seem to have considered him as a religious teacher before he reached old age, he was always circumspect in the management of the official ceremonial life of the shrine. Printed programmes relating to the celebration of the death anniversary of the Panchakkī saints from Yūsuf al-dīn's lifetime detail a full and expansive programme of events, including a procession $(j \bar{a} l \bar{u} s)$ through the city carrying the sandalwood that would be rubbed into the saints' tombs at dawn. But despite Yūsuf al-dīn's attention to the rituals associated with the Sufi shrines of India, as the heir to a tradition of Naqshbandī Sufism he was careful never to permit the musical performances (mahfil-e-sam $\bar{a}^{\prime}$ ) that were popular at other shrines in the city.

However, throughout his tenure Yūsuf al-dīn was never to possess complete control over the shrine. Government claims to Panchakkī both before and after the 
fall of Haydarabad found an appropriately bureaucratic symbolism, for after $1368 / 1948$ the former khanaqah buildings in the central courtyard of the shrine yielded from dervish to clerk as they became the headquarters of the Marathwada Waqf Board. ${ }^{21}$ As at the shrine of Shāh Nūr, until around 1368/1948 there seem to have been a number of dervishes resident at the shrine, who were able to live without charge in the khanaqah cells as they had for the past two centuries. But from this point on, many of the shrine's visitors would arrive on official business, coming less in honour of the saints than to attend a government office dealing with a whole range of personal and institutional revenues drawing on earlier Muslim religious endowments (awqāf). As tourism to the city increased from the 1960s, principally attracted to Awrangabad as a stop-over on the way to the more famous cave temples at Ellora and Ajanta, Panchakkî̀s earlier role as a place of local promenades found a new national and international audience. A gate was set up at the entrance to the outer courtyard with a ticket booth, while a number of trinket shops appeared around the great pool built by the Mughal commander, Jamīl Bēg. The income from tickets and shop rents, however, went to the state, and the expansion of tourism gradually ostracized the sajjäda nashins through many of the visitors' ignorance or plain disinterest in the shrine's Islamic associations. The saints of Panchakkī had always been liable to be outshone by the attractions of the pools and gardens of their burial place and with the promotion of Panchakkī as a tourist centre this effacement was to reach its zenith.

Like aristocrats bypassed by history, Awrangabad's Naqshbandī saints now came to receive the majority of their visitors vicariously, through the attractions of their splendid home. Given the popularity of evening promenades among British and Indian visitors to the shrine prior to the twentieth century, in some ways the transition of the shrine into the secular geography of the tourist itinerary did not involve any fundamental shift in the shrine's functions. ${ }^{22}$ And tourism did certainly augment the shrine's fame, with many visitors at least taking the trouble to visit the mausoleum of the saints in the inner courtyard, where they could be doffed with the peacock feather wand of the saints' servants (khuddām), who came increasingly to rely on the handouts of the tourists. Yet since the scruples and prudence of the travel industry are not those of the historian, Shāh Musāfir's reputation blossomed in response to the flow of tourists to his shrine. For despite the lack of any explicit connection in the Malfüzăt-e-Naqshbandiyya between the saint and Awrangzeb, from the Lonely Planet Guide to scores of Indian travel brochures and eventually websites, India's blossoming tourist literature painted the saint as the spiritual mentor and confidant of the emperor. ${ }^{23}$ With the age of the Persian hagiography now over, here was an unexpected new genre in which the saints could contribute to the fame of their city as they had in the saintly urban encomia of Sabzawārī and Bilgrāmī two centuries earlier.

During this period a number of objects that had long been esteemed as relics of Shāh Musāfir were placed on display behind a grill in the corner of the shrine. These relics included a huge set of prayer beads, a number of fragments of Ottoman cloth and ceramic, and two quivers full of arrows. We may recall Shāh Palangpōsh's carrying of a bow, though it is unclear if these arrows belonged to him or one of his soldiering devotees. Appropriately, there was earlier a Persian manuscript stored in 
the Panchakkī library by Sayyid Mīr 'Alawī entitled Hidāyat al-rāmī that was devoted to the theory and practice of archery. ${ }^{24}$ An inventory of the shrine's possessions earlier in the twentieth century had also described a wooden-handled leather whip (durra) used to punish wine-drinkers as among the relics of the saint, an object that reflected Shāh Musāfir's furious scolding of those followers he found using alcohol and cannabis. ${ }^{25}$ Despite the importance of such cult objects in earlier times, the decline of the popularity of Shāh Musāfir and the rise of modernizing tendencies among Sufis and other Muslims meant that the relics no longer bore any function other than as dusty curiosities to be briefly gazed at by tourists. By the 1990s, little remained in situ of the once famous library of the shrine other than a few printed works, including the Malfüzāt-e-Naqshbandiyya and Malkāpūrī's Urdu tadbkira of the Deccan's saints. But while the once rich manuscript collection had disappeared, tales continued to linger around the shrine that spoke of a secret library hidden in a locked room underneath the shrine and containing thousands of books; it was so secret that even the British never learned of its existence. Amid the literary destruction we have seen at Kalīm Allāh's shrine in Delhi and the wider cultural impoverishment of other Sufi shrines in colonial and post-colonial India, these stories were a poignant metaphor for a lost local patrimony.

After the death of Yūsuf al-dīn Maghribī in 1414/1994, he was succeeded by his grandson, Qāzī Taq̄ī Naqshbandī. Despite the family claim that Yūsuf al-dīn had nominated his grandson as his successor, the succession was disputed, not least because Yūsuf al-dīn had no sons of his own and his grandson was the son of his daughter. There soon emerged a rival sajjäda nashīn from Yūsuf al-dīn's family. This other (and elder) claimant asserted himself to be the closest male relative of Yùsuf al-dīn, though as in so many similar cases in India, this came to involve a variety of claims and counterclaims to kinship that were further complicated by the onset of litigation. If there was some ill will as a result, the rival claimant and his immediate family nonetheless remained in residence in the old residential quarter (zanana) of the shrine with other members of Yūsuf al-dīn's family.

Since Taqī Naqshbandī was still a child upon his succession during the 1990s, his mother took over many of the affairs of the shrine and some visitors to the shrine even referred to her as the sajjäda nashin. She claimed only to be the administrator (mutawaliyya) of the shrine, for according to tradition she could never be considered as sajjāda nashīn, not least because of the religious duties of the sajjäda nashīn to lead rituals among male pilgrims. Her role did, however, reflect that of Ghulām Mahmūd's two widows earlier in the century, acting as regent before passing on her position to a male successor whose interests she guarded. Partly as a result of the young age of the new sajjäda nashinn, by the 1990s the leadership of most of the religious activities of the shrine fell into the hands of Muhammad 'Abd al-Rashìd Wahdatī, a charismatic Sufi from Bidar to the north of Haydarabad. 'Abd al-Rashīd's moral authority grew further with the bifurcation of the official leadership at the shrine and the squabbling between its claimants. While legal wrangling with the state continued over the right to claim income from the shrine's landholdings, the ceremonial life of the shrine continued in a quiet way. With the tourists focussing on 
the pools and shady trees in the outer courtyard, and the bureaucrats and visitors to the Waqf Board milling between the offices of the inner court, the shrine acquired a divided life in which its chief religious function came to be as a place of daily prayer for Muslims living or working nearby. In a late nod to Naqshbandī sensibilities, the shrine's mosque finally outbid its adjacent mausoleum as the focus of Muslim devotion.

Since the 1970s, daily prayers at the mosque came to be led by the Sufi from Bidar, Muhammad 'Abd al-Rashīd. He also came to act in the place of the sajjäda nashinn as master of ceremonies during the performance of the death anniversary of the saints. But by the late 1990s, the death anniversaries of Shāh Musāfir and Shāh Palangpōsh were minor affairs. The processional element of the celebrations had been abandoned entirely and no more than thirty to forty adult males attended the gathering, with a still smaller number partaking in the ritual washing of the tombs in the mausoleum itself. Given the small circle that attended these rituals and the prominence of the Maghribì family as their hosts the atmosphere had much of the intimacy of a family gathering. Despite the small numbers, the stern Naqshbandī emphasis on the religious quality of the rituals gave the atmosphere an air of sincerity and piety that is sometimes lost at bigger celebrations of the saintly 'marriage' signified by the term 'urs. The Naqshbandī shrine of Shāh 'Ināyat Allāh at Balapur usually sent a representative at this time, while a small local band of dervishes were also assiduous attendants. Describing themselves as Naqshbandī-Shādhilī Sufis, they nonetheless comported themselves with the clamorous air of the old antinomian qalandars of the Deccan. All the same, the best attended element of these occasions remained the provision of a feast (langar) of mutton biriyani, the classic rice dish forever associated with Haydarabad and its Persianate culinary traditions. At other shrines in the city, the serving of the repast of mutton stew and bread known as nān-qaliya provided a symbolic culinary link with the past, for this was a dish held to have been introduced to the region during the original Muslim conquest of the Deccan in the late thirteenth century.

As the effective religious leader of Panchakkī, 'Abd al-Rashīd Wahdatī continued to pass on the traditions of the Sufis where others were unable to do so. Born in Bidar around 1333/1915, as a young man 'Abd al-Rashīd travelled to Haydarabad, where he received his first Sufi initiation. Like many Indian Sufis in recent centuries, he received a multiple initiation (bay'at) into the Chishtī and Qādirī orders, while his early initiation also placed him within a lineage of 'Aydarusī Sufis. These 'Aydarusī religious teachers migrated to the Deccan from southern Arabia from the medieval period to the reign of the last Nizām, and in this sense 'Abd al-Rashīd stood at the end of an important tradition of spiritual linkages between the Deccan and the Hadramawt. However, he also reflected a more local pattern among the Sufis of Awrangabad, namely the tendency from the late nineteenth century for the city's Sufi masters to be migrants from the capital of the Deccan at Haydarabad. Although 'Abd al-Rashīd did not leave Haydarabad until 1377/1957, almost a decade after the abolition of Haydarabad State, his move still reflected the old connections between the first and second cities of the former state played out during the previous two centuries. At the end of the twentieth century, these connections were still remembered by Awrangabad's Muslims, who continued to regard Haydarabad as having close 
religious and cultural links to their city. While the practical reasons for 'Abd al-Rashīd's relocation to Awrangabad lay in his assignment to the city as part of his work in the civil service, on moving to Awrangabad his Sufi inclinations led him to develop a close relationship with the shrine of Shāh Musāfir and its then sajjāda nashīn Yūsuf al-dīn Maghrabī, from whom he unusually undertook a second initiation into the Naqshbandiyya. This initiation later allowed some to see him as the true (if undeclared) heir to the spiritual legacy of the Panchakkī saints.

In many senses this was true, for 'Abd al-Rashīd not only led the formal ceremonies of the shrine but also convened regular weekly gatherings on the platform before the saints' mausoleum for the ritual performance of the remembrance of God (dhikr). Early on Sunday mornings, around a dozen of 'Abd al-Rashīd's followers regularly joined the servants of the shrine to sit cross-legged in a closed rectangle before the mausoleum. The first half of the Muslim profession of faith ('There is no god other than God') was repeated a number of times over with growing intensity, before the second half ('And Muhammad is His prophet') was brought in with a rhythmic change that re-established the master's control of the gathering and tempered its inclination towards ecstasy. In reflection of the classic Naqshbandī tradition of loud chanting (dbikr-e-bìl$j a b r)$, the voices of the participants took on a rasping tone, as though in reflection of the wearing away of the self that is at the heart of the ritual. Before the sound of rikshaws began to fill the air, the only accompaniment to the chanting were the songs of the many parrots in the surrounding trees. At such moments the scene seemed to resemble that described there by Sabzawārī more than two centuries earlier, where the master of Panchakkī was pictured leading a group of followers in chanting the same dhikr of the Central Asian masters of the Naqshbandiyya.

\section{Nizām al-d̄̄n}

The return to Awrangabad of Nizām al-dīn's ancestors from Delhi after the Great Revolt had brought a new line of sajjäda nashins to the shrine that ended with Mu'in al-dīn Qaysar Miyān. Given the historic ties between Nizām al-dīn and the Āsaf Jāh dynasty, the dissolution of Haydarabad must have been an special loss to Qaysar Miyān. Moreover, during the looting that accompanied the end of Āsaf Jāh rule almost all of the shrine's books and the family documents of Qaysar Miyān were destroyed by fire. Nonetheless, Qaysar Miyān's position as representative of a reputed saint and his own unorthodox but sincere spirituality did encourage a number of locals to seek initiation as his disciples, despite his reputation as something of a viveur. To them, he tried to pass on the traditions of not only the Chishtiyya but also of the mulki legacy of Haydarabad's rich cultural synthesis. ${ }^{26}$ As such, the reading of Urdu poetry and the enjoyment of classical Indian music seem to have formed a more important part of his spiritual teachings than the formalities of the religious law. Qaysar Miyān acted as sajjāda nashīn at the shrine until his death in 1385/1965. However, like Ghulām Mahmūd at Panchakkī a few decades earlier, Qaysar Miyān died without any children from his wife. While the landholdings of the shrine had lapsed to the state two decades earlier, after Qaysar Miyān's death the living quarters 
of the shrine became the residence of a previously unacknowledged daughter and her North Indian husband, known throughout the city as Muhammad Miyān. ${ }^{27}$ Over time, through his scrupulous attendance to the duties expected of a sajjäda nashin and the humble attention to the traditional etiquette (adab) of the Sufi with which he performed them, Muhammad Miyān was accepted by many of the shrine's clients as the rightful heir of Nizām al-dīn. By the 1980s, he had taken on the duties of sajjäda nashīn and remained in this position at the century's end.

Muhammad Miyān's work at the shrine during the last two decades of the twentieth century is illustrative of the ways in which the traditions of the Sufis have been able to transmit themselves through time. For his public behaviour in the role of sajjäda nashīn demonstrated the ways in which hagiographic traditions of saintly morals and decorum translate themselves into practical models for imitation in everyday life. Muhammad Miyān treated the shrine that was under his care as an open house, regularly coming from his own quarters to greet visitors and offer them tea and cigarettes. With money brought in through the partial success of a court case to claim an income from the state, during the 1990s Muhammad Miyān made efforts to restore the shrine and render it more comfortable for devotees. Two guest rooms were built in the main courtyard, and a new concrete roof was added over part of the main courtyard to shelter devotees from the sun and rain, particularly during the musical concerts (mabfil-e-sama $\bar{a}^{\prime}$ ) that accompany the saint's death anniversary. Similar effort was put into attempts to restore the shrine's traditions of learning through the acquisition of photocopies of manuscripts or printed works pertaining to Nizām al-dīn for the creation of a small library to replace the one destroyed earlier. A considerable sum of money was expended in the translation into Urdu and subsequent publication of Kāmgār Khān's Absan al-shamā'il on the teachings of Nizām al-dīn, while efforts were also underway for an Urdu translation of Nizām al-dīn's Nizām al-qulūb. ${ }^{28}$ These activities formed important contributions to the transmission of a local tradition of Sufi learning, for the Absan al-shama' $i l$ had never previously been published and existed only in rare manuscript copies. Under Muhammad Miyān's administration, the shrine also won local renown for the quality of the praise-singers (qawwāls) brought from Haydarabad and even from as far as Delhi at the time of Nizām al-dīn's death anniversary.

In these ways, Muhammad Miyān endeavoured to revive the shrine as the centre of a specifically Chishtī tradition of Sufism. In this, he was helped by a local college teacher, Sayyid Hasan. Placing emphasis on not only the Chishtī tradition of musical performances but also on its tradition of 'peace to all' (subl-e-kul), Sayyid Hasan sought to present a tolerant vision of Sufism as the answer to India's problems of communal violence and Islam's own problems of violent expression. As a religious teacher, Sayyid Hasan had his own clear vision of Sufism's role in the twenty-first century and of the timelessness and adaptability of the Sufi message, which he has presented as open to all, regardless of religion, race or class. He has also composed an Urdu hagiography of Nizām al-dīn, which is made freely available to visitors to the shrine and which emphasizes the importance of musical audition $(\operatorname{sam} \bar{a})$ in the teachings of Nizām al-dīn. ${ }^{29}$ In the last years of the twentieth century, Muhammad Miyān and Sayyid Hasan - the institutional representative of the saint and the inspired 
reviver of his teachings - hosted hundreds of visitors during the death anniversaries of Nizām al-dīn, to which people continued to travel from throughout the former territories of the Nizām's State, and from Haydarabad in particular.

As a result of his earlier growth in fame, in the last decades of the twentieth century Nizām al-dīn remained the most famous of the city's saints beyond its own borders and was the only one of the Awrangabad saints to attract pilgrims in any number from beyond the city. Although Haydarabad State had disappeared in 1948, the memory of the saint's association with its foundation continued to be of importance and this lent Nizām al-dīn a special role in the self-history of the Deccan Muslims. This role continued to be emphasized in the Urdu accounts of his life written throughout the twentieth century, and legends circulated describing Nizām al-dīn as the true founder of the state for at least a century prior to the end of Haydarabad. The oral tradition of the shrine as transmitted by Muhammad Miyan claimed that all of the Nizāms came to the shrine upon their coronation to be invested with a sword (talwar) at the hands of the sajjäda nashinns of Nizām al-dīn. While the historicity of these claims is hard to verify in view of the loss of the shrine's archives, they seem to have been widely believed and Nizām al-dīn's reputation as the patron saint of the Nizāms was known throughout Haydarabad. While the shrine and its keepers looked to the future in their promotion of a spirituality compatible with secularism and religious pluralism, the shrine also continued to act as a locus of historical memory. It was partly in reflection of the shrine's older reputation as patron of the Âsaf Jāh state that large numbers of pilgrims continued to attend Nizām al-dīn's 'urs from throughout the Deccan. Intimately tied with the memory of the disappeared Nizām's State, the name of the saint acted as a symbol for the history of the Deccan's Muslims more generally. Among its many other functions, the shrine of Nizām al-dīn became a place for its clients to encounter their community past, where royal and saintly glory were brought together beneath a single yellow cupola. In one act of homage to that past, Mukarram Jah, the son of the last Nizām, was said to have paid an unannounced pilgrimage in reflection of the visits paid to the saint by his ancestor, Nizām al-Mulk.

\section{The literary tradition}

\section{An overview}

As we have seen, in the middle of the twentieth century Awrangabad experienced the latest of several major shifts in its political identity, finding itself subsumed into the vast territory of the Indian Union. This period of social and political re-definitions formed the background for the writing of a number of new individual hagiographies of the Awrangabad saints that were often distributed from the shrines of the saints. Although such chapbooks have received little scholarly attention, they form the most widespread modern literary means of disseminating traditions of Muslim sainthood throughout the Islamic world. In modern times, most shrines of local importance in India and Pakistan have made use of this inexpensive form of printed pamphlet biography. Rarely more than forty pages in length, they are often composed in Urdu 
from the Tamil south to the Pashto north and as such are testament to the steady transformation of Urdu into the sacred language of the Muslims of South Asia. However, their meagre stylistic merits, often connected to an intended readership possessing only basic literacy in Urdu, have meant that they have received little attention from the arbiters of Urdu letters. But as the heirs of an earlier tradition of saintly literature, such biographies prove a valuable resource in charting further changes in saintly identities as well as in demonstrating the continued embeddedness of Sufism in wider cultural developments.

Nonetheless, the popularity of the hagiographical chapbook did not mean that longer works were no longer written. Writing in the late 1980s from Pakistan, to which many Haydarabadi Muslims had migrated after the end of the Nizāms' rule, the female poet Wahīda Nasīm composed a new work on the saints of Khuldabad, entitled

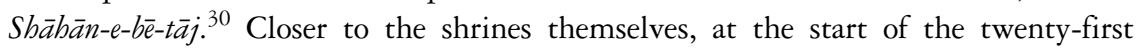
century another fulsome collective work was published on Khuldabad's saints and kings. This work, Gulistān-e-Khuldābād was written by Muhammad 'Abd al-Hayy, a senior servant (khādim) of the Khuldabad shrines. ${ }^{31}$ Though often derivative, in places drawing heavily on Rawnaq 'Alī's Rawzat al-aqtāb of seventy years earlier, Gulistān-eKhuldābād still contained new material on the Khuldabad Sufis. A great deal of detailed material was presented in the work on a whole series of Sufis connected with Khuldabad, in this way creating a book like that of Rawnaq 'Alī which was both academic and hagiographical. Yet with the passing of time, the relationship of the saints with the Muslim rulers of the area moved still closer to centre stage, and the work contained lengthy sections on the family of Awrangzeb and Nizām al-Mulk. However, here was no merely nostalgic account of a bygone age, and particular attention was given to the cultural achievements of such figures, through presenting the poetry of Nizām al-Mulk's son Nāsir Jang and other figures to a new audience. Similarly, a section of the text was devoted to the evocation of Awrangzeb in the poetry of Muhammad Iqbāl (d. 1357/1938), who had visited the emperor's tomb earlier in the century. ${ }^{32}$ But despite the detailed accounts of the earlier history of the saints, kings and the architecture they shared in Khuldabad, evidence of the association of its shrines with more recent prestige figures remained as much a feature of this as of earlier hagiographical works. Now, however, the Muslim kings and poets of old had been replaced by the representatives of a newer world order, including India's first Sikh President, Giani Zail Singh, and foreign scholars such as the late Annemarie Schimmel. Photographs of the visits of these and several similar figures are included in the book, so lending a new technological apparatus for proving the status of the saints.

\section{Panchakkī and the disappearing past}

We have seen how by the early nineteenth century Panchakkī became the focus of a local tradition of promenades that (in the eyes of foreign visitors at least) had come to take precedence over the shrine as a destination for purely pious visitation. ${ }^{33}$ In the twentieth-century textual tradition of the saints no less than in the practice of pilgrimage, the shrine itself caught the attention of memorialists more than the 
deeds of the Sufis buried there. This had been no less the case with history-writing in Awrangabad, for in the Tāri $k h-e-K h \bar{u} r s h \bar{\imath} d J \bar{a} h \bar{\imath}$, a late nineteenth-century Urdu history of Awrangabad, it was again the shrine and its builders that elicited description rather than its saintly inhabitants. ${ }^{34}$ This emphasis on a tangible architectural legacy rather than a supernatural one was also reflected in a history of the shrine that was probably written during the 1950 s by Mubāriz al-dīn Raf'at, whom we have seen was a friend of the shrine's sajjāda nashīn, Yūsuf al-dīn. Entitled Panchakkī-yeAwrangāba $\bar{a}$, Raf'at's book echoed the transformation of Panchakki from purveyor of miraculous aid to symbol of the historical patrimony of Awrangabad's Muslims. ${ }^{35}$ Architectural commemoration had become more important to the memory of Shāh Palangpōsh and Shāh Musāfir than accounts of their deeds. Insofar as they were remembered it was due almost entirely to the architectural legacy of their early patronage by the Central Asian elite of the early eighteenth century.

It is perhaps ironic that while Muslim saints are commonly eulogized as the glory of their age, in the case of the saints of Panchakkī the saints' glory came to be perceived conversely as owed in large part to that of their age. This formulation of saintly memory as based on an association with cultural and political halcyon days similarly underwrote the fame of many other of the great saints of India, as seen in the association of the circle of Nizām al-dīn Awliyā with the Delhi Sultanate, of the Chishtīs of Khuldabad with the coming of Islam to the Deccan under 'Alā' al-dīn Khaljī and of Gēsū Darāz with the glory of the early Bahmani rulers. Such an association of shrine and court showed itself clearly in the architectural style of Panchakkī, its architectural parts mirroring the magnificent garden-tomb of the wife of Awrangzeb just across the city. The shrine of the Naqshbandī shaykhs had come to symbolize the city's history no less than the mausoleum of the emperor's wife.

The saintly association of architecture, books and memory continued at Panchakkī after the end of Āsaf Jāh rule. Attracted by the lingering air of a bygone age, the shrine's new touristic visitors were still taking part in a modern transformation of an earlier tradition of shrine visitation. For we have seen the popularity of the shrine's gardens with earlier generations of Britons and local people in Awrangabad. In a strange way, the diverse new bands of visitors represented a new clientele of the shrine, many of them receiving blessings from the graves of the saints at the insistence of their servants (khuddām). Continuing an earlier (albeit more local) tradition of recreational visitations to Panchakkī, like earlier generations of clients they also contributed to the income of the shrine. It was for these visitors, mainly from Bombay and elsewhere in Maharashtra but sometimes from abroad, that the last document of the lives of the Panchakkī saints was composed. Written in English in the early 1980s, this ten-page pamphlet completed the process of the saints' eclipse by their architectural legacy, a moment of penumbra caught in its title of Glimpses of Panchakee.

As the libraries disappeared and the city's Muslims, in their changed circumstances, became more conscious of the fragility of their heritage, M.A. Jabbar's Glimpses of Panchakee achieved a brief respite from this wider sense of loss. Although written for a new touristic readership, Jabbar's booklet drew on the Malfüzāt-eNaqshbandiyya for its descriptions of the construction of Panchakkī and short 
accounts of the lives of the saints buried there. Intended for a readership interested primarily in the delightful pools and fountains of the shrine, Jabbar's pamphlet nonetheless reminded its readers of the distinguished local past to which the shrine belonged. But despite Jabbar's use of the Malfüzāt-e-Naqshbandiyya, there was no mention of the more unusual activities of the saints and their followers, of partisan miracles and feral transformations. The saints had lost the individuality of their identities and become before all else philanthropists and teachers. But with the end of the twentieth century, there came a new possibility for local people to re-connect with the stranger heritage of the city's Naqshbandis when copies of the first Urdu translation of the Malfüzät-e-Naqshbandiyya went on sale in the shops at the shrine.

\section{Change and renewal in the Life of Shäb Nūr}

Some years after the dissolution of Haydarabad, a new Urdu biography was written by a local follower of Shāh Nūr. Entitled Âftāb-e-dakan, it was written by Tārā Sāhib Qurēshī, a successful local betel nut trader and member of the committee established to govern Shāh Nūr's shrine after the death of its reviver, Shams al-dīn. ${ }^{36}$ Compared with the historical and tourist literature associated with Panchakkī, this chapbook hagiography of Shāh Nūr was written for a more conventional readership of Muslim pilgrims. Being composed in Urdu, Âftāb-e-dakan targeted but also considerably narrowed its intended audience in a region in which Marathi had become far more widely understood and at a shrine that counted many local and village Hindus among its clientele. Compared to the Persian lingua franca of the texts of the Mughal and $\bar{A}$ saf Jāh periods, $\bar{A} f t \bar{a} b-e-d a k a n$ thus reflected a foreclosure of the reception of Sufi biographical literature. Aftāb-e-dakan's contents drew in large part on the earlier accounts of 'Urūj (as preserved in a modern Urdu translation) and Malkāpūrī, as well as on miraculous narratives known only in oral tradition, and in doing so the work presented a pious but nonetheless miraculous Muslim figure. Nonetheless, the image of Shāh Nūr as miracle-working holy man underwent a compromise with the doctrinal formulations of the Barēlwi school. In the introductory section of the text,

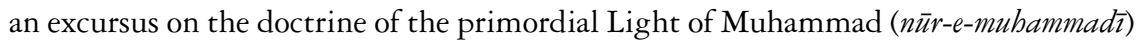
bears the hallmarks of the Barēlwī theological underpinnings of devotional Islam which we have seen become attached to the shrine through the foundation of an associated madrasa there. ${ }^{37}$ In line with the Barēlwī emphasis on devotion to the Prophet Muhammad, Shāh Nūr now appeared in their doctrinal guise. Following all of the prescribed duties of the religious law, in the manner of a proper product of the seminary at Bareilly Shāh Nūr showed his elevated devotion to the Prophet by regularly reciting the Arabic Qasīda Burda Sharîf written in his honour by al-Būsīrî (d. c.694/1294). ${ }^{38}$ Such Barēlwī elements jarred somewhat with the miraculous stories lifted from the earlier Urdu tradition of 'Urūj and Malkāpūrī. However unwittingly, this textual collage echoed the wider tensions at the shrine between the reformists and the followers of an older miraculous ideal of sainthood. But reflecting the role of saintly biography in the broader preservation of historical memory, $\bar{A}$ ta $\bar{a}$ e-dakan also included a long section on the life of the courtly disciple of Shāh Nūr, 
Diyānat Khān, that drew on Khāfī Khān's early history of Awrangzeb. Despite the input of reformist influences, the shrine's links with an older Muslim social world thus lingered until the end of the century. By this time Diyānat Khān had acquired a reverence of his own as the 'pious vizier' whose tomb in a separate courtyard at the shrine became incorporated into the ritual life of Shāh Nūr's devotees.

$\bar{A} f t a \bar{b}-e-d a k a n$ presented a renewed image of the saint that tailored certain aspects of his cultic identity to the shifting cultural circumstances of the new 'Indian' Awrangabad. Although the text did not alter the version of Shāh Nūr's sayyid parentage given by Malkāpūrī, his place of birth was shifted, this time to the town of Hamat in Khurasan. This may have been the result of a confused association of Shāh Nūr's earlier connection in the earlier hagiographical tradition to the sayyids of the Syrian Hama with the celebrated Khurasani homeland of many major Sufis. The text also added elements of the reformist vision of sainthood seen earlier in Naqwis's Barakāt al-awliya $\bar{a}$. Reflecting the powerful influence of the missionary model in colonial India, Shāh Nūr's purpose in leaving his homeland was expressly described as having been to spread the teachings of the Prophet Muhammad. ${ }^{39}$ The spirit of Indian nationalism also managed to seep into the text through attempts to identify the saint more closely with the new nation. We have seen in Chapter 4 how the revival of the shrine in the early twentieth century heralded the introduction of a Chishtī affiliation in the cult through the association of the reviver Shams al-dīn with Ajmer. In $\bar{A} f t \bar{a} b-e-d a k a n$, we see the transformation of a saint earlier connected to the towns of Syria and Iraq into a figure more in tune with modern ideas of national identity linked to the Chishtiyya. Shāh Nūr's extensive travels en route to Awrangabad were thus amended, adding a stronger Indian and particularly Chishtī dimension to the saint's Wanderjabren. Though not abandoned, his earlier prestigious associations with Egypt, Baghdad, Balkh and the Hijaz were eclipsed by the introduction of the Chishti centres of Gulbarga and Ajmer to his itinerary. The text also described how the saint spent a long period of residence in both cities learning from the masters of the Chishtiyya, while his visits to Delhi and Agra were given renewed emphasis. ${ }^{40}$ This was not only a reflection of shifting religious and cultural alignments in an age of nationalism, but also a vision of the Sufi past itself conceived in terms of a latter-day geography of pilgrimage. This was only appropriate, for Urdu chapbook hagiographies like $\bar{A} f t a \bar{b}-e-d a k a n$ were deeply connected with the practice of shrine visitation, generally being composed for a readership of pilgrims unfamiliar with the oral narratives known to local devotees. Such a concern with cult practice is seen in Aftāb-e-dakan itself, where, reflecting Malkāpūrī, the distinctive custom of Wednesday pilgrimage to the shrine of Shāh Nūr was explained and reified with reference to the life of the saint.

Like the earlier textual tradition, the vision of sainthood given in $\bar{A} f t a b$-e-dakan was one embedded in wider discourses of social and class identity. This was seen in the emphasis Aftāb-e-dakan placed on the high social class of Shāh Nūr's followers, ${ }^{41}$ with the disciple Diyānat Khān - now regarded as having been the vizier (waž̄ir) of Awrangzeb - receiving a considerable separate section to himself as a kind of courtly counter-biography within the saintly text. ${ }^{42}$ Despite the continuing narrative association of Shāh Nūr with Awrangabad's Muslim elite, the new chapter in the history of the 
shrine of Shāh Nūr heralded by the end of Haydarabad's independence had seen a considerable change in the status of its patrons. This was witnessed in the compositional history of Âftāb-e-dakan, for while Shāh Nūr's earlier biographer 'Urūj was better known as a writer of the poetic anthologies that flourished during the reign of Nizām 'Alī Khān, and the later Malkāpūrī was one of the best known Deccan historians of his day, Shāh Nūr's final biographer owed his fame rather to a flourishing business in betel nuts.

The fall of Haydarabad State had robbed the shrine of all but the last traces of the courtly patronage that had continued into the earlier part of the century in the association of the Nizām's Minister for Religious Affairs and his Hindu prime minister Kishan Parshād. The committee that was subsequently formed to administer the shrine's activities became dominated by Awrangabad's merchant middle class. ${ }^{43}$ Exemplifying the consolidation of the position of this new class of patrons, a generation later the committee was being governed by the son of Shāh Nūr's biographer, Tārā Sāhib Qurēshī. Here there was a kind of parallel life at the shrine, in which textual no less than oral tradition continued to associate the shrine with a clientele of courtly elites, while the shrine in actual fact experienced a sharp narrowing of its zone of patronage to the surrounding Othmanpura quarter. But just as this locality possessed a social hierarchy of its own, dominated by local businessmen, the continued narrative emphasis upon a circle of high-class Muslim patrons and devotees structurally reflected the existing social facts of a shrine frequented by predominantly lower-class Muslims and Hindus but governed and patronized by the new Muslim elite of the Othmanpura quarter. Composed by the major figure of this new generation of patrons, the tales of the saint and his noble early patrons in A ftāb-e-dakan provided a mantle of prestige that could be shared equally between the shrine and its new patrons.

\section{Nizām al-dìn and the lingering image of the Nizāms}

Nizām al-dīn was late in receiving a new Urdu biography. While this may have reflected management and financial problems at the shrine after the death of its sajjāda nashīn Qaysar Miyān in 1385/1965, it may also have been a reflection of a decline in the popularity of a saint closely connected with a state so ignominiously swept away by the forces of history. Although short accounts of Nizām al-dīn's life continued to crop up in Urdu publications throughout India and Pakistan, it was not until the late 1990s that a new hagiography was written for him in Awrangabad, entitled Zindag $\bar{\imath} \bar{u}$ Hălāt-e-Nizām al-dīn Awliyā Awrangābād $\bar{a}$. The author of this chapbook was Sayyid Hasan, the local college teacher and devotee of Nizām al-dīn whom we have seen connected to the shrine in the last decade of the twentieth century. The paucity of the surviving textual heritage of Nizām al-dīn in Awrangabad was reflected in the composition of this biography, which had to be written without resort to the Absan al-shamä'il and other early sources. Apart from the inclusion of a few anecdotes drawn from Malkāpūrī and the adoption of the grandiose image of the saint in oral tradition, large portions of the text were based without attribution on the account of Nizām al-dīn given by the modern Indian 
scholar of Sufism, Khāliq Ahmad Nizāmī (d. 1997) in his Tārìkh-e-mashä'ikh-e-Chisht ('History of the Shaykhs of Chisht'). ${ }^{44}$ Though of great influence in modern scholarly attempts to reconstruct Indian Sufi history, this work in itself served to highlight one Chishtī lineage at the expense of many others. Although perhaps an unusual diversion for a hagiography to take, Sayyid Hasan's usage of Nizāmī’s work is nonetheless suggestive of the discontinuities of transmission that have at times lain behind the creation of Sufi hagiography.

Like other examples of its genre, the Zindagi $\bar{u} H \bar{a} l \bar{a} t$ was concerned with the maintenance of saintly prestige vis-à-vis local sources of competition. Most important in this respect was its repetition of the tradition of the spiritual jurisdiction (wiläyat) granted to Nizām al-dīn by his master Kalīm Allāh over the entire Deccan. This claim, made through an appeal to what was now a suitably sanctified 300-year tradition, portrayed Nizām al-dīn as the senior saint of the Deccan and as the successor to the earlier Chishtī saints of Khuldabad and Gulbarga. ${ }^{45}$ We have seen the political subtext of this Delhi-centred configuration of northern authority over the Deccan, but here the claim was pointed more directly at competing shrines in Awrangabad and the Deccan. These cult rivalries were borne out in the contexts of the text's composition and during the late 1990s it was held by some of the associates of the shrine that the great Chishtī shrine of Gēsū Darāz at Gulbarga concealed written evidence in its celebrated library of the association of Nizām al-dīn with Nizām al-Mulk out of fear that this information would challenge Gēsū Darāz's pre-eminence in the Deccan. But despite the influence of these rivalries, the hagiography did preserve elements of the earliest written account of Nizām al-dīn in the Absan al-shamä'il as transmitted via the work of Nizāmī. For amid the familiar hagiographical apparatus of saintly origins and pedigree and the ever-growing shadow of royal associations was included a picture of Nizām al-dīn as a great defender of the practice of listening to music and as a holy man accessible to devotees of all religious creeds. ${ }^{46}$ However influenced by modern nationalist ideology, this was also a picture that was quite in keeping with the image of the Sufi as the friend of Hindus first described in the Absan al-sham $\bar{a}^{\prime} i l^{47}$

Reflecting the prominence of Diyānat Khān's biography in the Affāab-e-dakan, the career of Nizām al-dīn's stately associate Nizām al-Mulk was recounted in Sayyid Hasan's text in considerable detail. ${ }^{48}$ Although drawing on Malkāpūrī or oral tradition in repeating the narrative of the sandalwood handprints at the battle of Shakar Kera, the text went much further in its descriptions of saintly influence than its predecessor. Drawing on widespread oral tradition, it stated in no uncertain terms that the title nizām ('orderer [lit. "good order"]') of the Nizāms of Haydarabad was chosen in honour of the saint, whose favourite yellow colour also became the official emblem of Haydarabad. ${ }^{49}$ In resorting to historical narrative as the keystone of saintly identity, the text demonstrated how remembrance of the past continued to be a key constituent of the phenomenon of sainthood. This was all the more striking in a hagiography written half a century after the collapse of the state with whose historical genesis the saint was concerned. Yet Awrangabad's Muslim past remained important and the same narratives of royal association were emphasized in a biography of Nizām al-dīn printed in a local Urdu newspaper in honour of his death anniversary in 1421/2000. ${ }^{50}$ 
Four decades after the formation of the state of Maharashtra - the cradle of renewed Hindu no less than Maratha nationalism - for many of the Muslims in its second city of Awrangabad the memory of their lost state was far from forgotten. This did not represent a spirit of disloyalty to India, but an upholding of a distinct community memory that was no doubt reinforced by the promotion of an 'official' history of Maharashtra dominated by the Maratha leader Shìvājī and his antagonism towards Awrangzeb and his Muslim followers. From its beginnings, the textual tradition of the Awrangabad saints had been entwined with a broader raft of community memory. Two and a half centuries later that relationship remained unbroken.

\section{Oral hagiography and bistorical memory}

As in many Indian cities, an earlier townscape still defined much of the character of Awrangabad at the end of the twentieth century, connecting the daily lives of its inhabitants in however feeble a way to those of their predecessors. The past needs always to be mediated and handed on and for many of the residents of Awrangabad this mediation has been achieved in part through the combination of the oral tradition of the saints and the surviving architectural signs of the past. For the past is primarily known to the city's inhabitants in the form of its surviving architectural presence, amid which its Sufi shrines loomed large as among the few living architectural spaces connecting Awrangabad's past with its present. Other remnants, including walls, gateways and royal funerary and residential buildings, were also significant in clearly belonging to the same historical and cultural epoch. Yet these monumental pointers to the past required a narrative framework in order to be understood. Amid this wider process of configuring historical memory, the narrative figure of the saint gave structure to the wide plains of the past through descriptions of the saint's miraculous life-story which connect past and present experience in meaningful ways. With the saint forming a common point of reference, the legends that have gathered around him embrace the kings, courtiers and other notable figures from the city's past, as well as the imperial city itself as their setting. The oral tradition surrounding the city's saints has not merely provided the distinctly religious biographies of a local pantheon of Muslim saints, but has also formed a history of the city and its Muslim community. It has presented a past (and so by implication a present) in which God's presence in the world is made manifest through the actions of his saintly representatives and has in this sense formed a historical tradition that might be seen as combining local and wider Indo-Islamic features.

The architectural presence of a shrine presents the power of a saint in a concrete symbolic expression of sacred space. But though forming the geographical centre of a saintly cult, the physical existence of a shrine is not in itself sufficient to maintain or disseminate a tradition. For this, each shrine has had to rely upon narrative traditions advertising and demonstrating the miraculous powers of its saint in specific forms, a narrative process that in turn required such sponsors as a faction of supporters, sajjäda nashins or literary commemorators. The interconnectedness of shrines with the narrative traditions of their saints was seen in the ways in which narratives were deliberately 
connected to, and at times even modelled upon, the spaces and architectural forms of the shrines themselves. ${ }^{51}$ For shrines often provided a narrative framework forming a concrete mise en scène for spoken and written narratives concerning the saint's miraculous interaction with his devotees. This experiential reality of the shrine evoked the vividness with which hagiographical narratives were received in their living contexts. This anchoring of the stories of the saint onto the shrine cast a kind of narrative spell on the built environment of the saintly tombs. At any point in a shrine's history, this process formed the final and narrative factor in the creation and maintenance of a saintly tradition. Narrative traditions were always in this sense the lifeblood of the saints.

The most basic form of the process of drawing the shrine into the supernatural world of the saints was through stories concerning the actual building of shrines. The refinement of the architectural presence of each of the Awrangabad shrines was both the starting point and proof of oral traditions ascribing royal associations to their saints beyond the scope of historical fact. The building of Panchakkī was thus attributed in oral tradition to Awrangzeb himself, who was painted as a devoted follower of Shāh Musāfir, while Nizām al-Mulk at times became similarly regarded in oral tradition as the builder of the shrine of Shāh Nūr. However, the process is best seen with reference to a tradition associated with the building of the mosque at the site of Shāh Nūr's first residence in the Moti Karanjar quarter. One oral tradition describes how Shāh Nūr's devotee, Diyānat Khān, offered to build this mosque for him, but Shāh Nūr was at first unwilling to give his permission. ${ }^{52}$ After much persuasion, Shāh Nūr finally allowed the construction to go ahead on the condition that the mosque could be built between the hours of the evening and dawn prayers. Through the saint's miraculous goodwill, this apparently impossible task was achieved. As itself the result of a saintly miracle, architecture here provided material testimony to a saint's power. The story reflected a more famous tradition concerning the building of the Arhāì-din-kā-Jhōnprā ('two-and-a-half-day mosque') in Ajmer.

A similarly close mirroring of architecture and narrative could be seen at the actual shrine of Shāh Nūr. A story of Shāh Nūr competing for the attentions of a devotee with a flying Sadhu became rooted into the sacred space of the saint through the narrative absorption of the shrine's architectural features. The seating platform (chabūtra) on which the tradition described Shāh Nūr as sitting during this encounter was identified with that beside his shrine. The stream in which this platform was positioned was in turn drawn into the narrative, its name of Shirapuri being regarded as given in honour of the sweetmeat (shīrapiurì) with which Shāh Nūr commanded it to flow in the legend. This narrative focus on platforms and streams was also reflected at the Sadhu lodge of Shāh Nūr's Hindu companion, Mānpūrī. In the lodge there stands a stone seat (nashist) identified as the site of the anthill that was built around Shāh Nūr as he sat in long years of breath control. Such platforms and meditation seats also formed part of the tradition of devotion to Sadhus in India and had no less a role in their narrative cycles. The stream that ran beside Mānpūrī's lodge took on similar narrative form as having miraculously appeared on the very spot of Shāh Nūr's meeting with Mānpūrī. A miraculously moving wall which Mānpūrī was said to have ridden to meet Shāh Nūr was identified with a length of wall 
standing incongruously in the middle of the lodge's courtyard. ${ }^{53}$ This echoed wider legendary Sufi motifs, with walls of other wall-riding saints similarly displayed as the proof of oral tradition at Sufi shrines in Multan and Uchch in Pakistan, as well as at a number of sites in Anatolia. The collective imagery of site and tale also shows how Muslim saints shared much of their symbolic vocabulary with their wider Indian environment. The popular Indian cultic associations of seats, springs and walking-walls were reflected in traditions associating the saints with large old trees in the shrines; the huge banyans in the outer courtyards of Panchakkī and Shāh Nūr were regarded as the sites of the saints' meditation. The construction of shrine and legend mirrored one another in this overlapping between the places of narrative and lived experience.

Decoration formed a similar means of tying the narratives and shrines of the saints together. In modern times at least, this was most evident in the use of colour at the shrine of Nizām al-dīn, where the saint's mausoleum was entirely painted in a bright and beaming yellow. ${ }^{54}$ This colour served as a visual reflection of oral traditions that held that Nizām al-dīn always dressed in yellow and had a particular affection for that colour. In a ritual reflection of architecture and narrative, yellow turbans and skullcaps were worn during the saint's annual death anniversary. Here lay a rich set of references, for with its strong associations with marriage and the coming of spring, yellow was widely regarded in the Deccan as the colour of life itself. Long associated with beauty, yellow played an important part in the Hindu festivals of spring, while at Hindu and Muslim weddings in the Deccan turmeric was often employed in place of henna both as a beautifier and to protect the bride from the evil eye. Yet the yellow colour of Nizām al-dīn's shrine also bore political associations, for it was the official colour of Haydarabad State. The Āsaf Jāh flag, postboxes and other official insignia were all yellow in colour. ${ }^{55}$ The circle in the centre of the flag was regarded as signifying the piece of bread ( $r \bar{o} t \bar{i}, k u l c h a)$ that the saint gave to Nizām al-Mulk to miraculously bestow upon him rule over the Deccan. ${ }^{56}$ In this way, the decoration of the shrine served to ratify the association of Nizām al-dīn with the family and state of the Haydarabad Nizāms, as celebrated in the most famous stories concerning the saint. In a local context of competition between rival saintly geographies, the shrine's bearing the official colour of the (former) state acted as a powerful declaration of Nizām al-dīn's claim to the status of first saint of a city that had once ruled over the whole Deccan.

In the mirrored worlds of the architecture and narratives of sainthood, the shrines formed a living environment in which the miraculous lives of the Sufis could be traced by their devotees. As an interface between past and present time, the charged narrative presence of the shrines was capable of uniting miraculous narratives and the spaces of pilgrimage into a single experiential whole. Through this continuum of place and meaning, Islam became local and indigenous, while maintaining its connections with older sacred geographies through narratives of the saint's birth, initiation or travels in such cities as Mecca, Baghdad or Bukhara. Here was the creation of new Muslim territory through the infusion of the built environment with historical and spiritual meaning. For what was visible in the architecture of the shrines was not a Sufism of abstract theories and metaphysical refinement, but a means of writing the epiphanies of local history into the urban fabric of everyday life. 


\section{CONCLUSIONS}

In the previous chapters we have seen how the practice of Sufism was concerned not only with the states of the soul and the eschatology of the hereafter, but also with the physical conditions of life on earth. Although in their later Urdu biographies the Awrangabad Sufis were eventually re-cast as high-minded teachers of scripture and pioneers of social welfare, however anachronous, their reformist biographers were correct to emphasize the importance of the Sufis' relationship with life in the world. During their lifetimes, the Sufis of late Mughal Awrangabad turned their powers towards curing the sick, retrieving stolen property or protecting favoured followers during a period of great socio-political upheaval. For as well as a path to a transcendent personal salvation, Sufism was also a means of amplifying human volition in an uncertain and often hostile world. This was the Sufism of miracle and wonder that was probably altogether its most familiar public aspect, in past and present. Like their partial equivalents in other milieux - sabios, shamans, cunning men - such Sufi men of power fulfilled an essential social function in providing the hope and possibility of protection against sickness, drought, violence or any of the other manifold insecurities of life. While the promise of mystical gnosis always pervaded Sufi activity to a greater or lesser degree, it was these more mundane capacities that bore the greater responsibility for the extraordinary success that the Sufis and their cults achieved. Nonetheless, as we have seen in the preceding chapters, these miraculous dimensions of Sufism can never be fully separated from the 'closeness' (qurbat) of the Sufis to God that rendered both mystical enlightenment (ma'rifat) and miracles (karāmāt) equally possible. While some modern commentators may prefer a Sufism of certain knowledge to one also comprising the working of wonders, the fact remains that the roots of Sufism lie as far beyond the historical limits of modernity as they do beyond the philosophical boundaries of modernism. This conflict between modern and premodern mentalities was manifested in twentieth-century Muslim representations of Sufi history no less than in Western scholarly accounts from the same period. But as we have seen in the various ways in which Awrangabad's Sufi legacy was passed on, whatever attempts are made to colonize or integrate it, the past truly is another country whose contours can never be clearly mapped in the present.

The miracles of the past nevertheless left a concrete legacy in their wake. For the result of the widespread belief that as God's special saintly 'friends' (awliyā) powerful 
Sufis possessed the ability to work miracles and so change the ordinary course of history was their increasing social status and material wealth. As Shāh Palangpōsh was fond of pointing out, divine intervention came at a price to its recipients, a cost that was expressed as nadbr, the Islamic articulation of the primordial gift to the gods. If Western scholarship once fought shy of this entanglement of Sufism with the riches of the world, our understanding of it need no longer be formulated in terms of decline or even simple regret. On the contrary, it was only in the meeting of the worlds of the shaykh and the sultan that Sufism was able to gain the patronage necessary to survive and flourish. While this did introduce a spiritualized aristocracy to the world of Islam (in India and elsewhere) in the form of the powerful class of sajjäda nashins represented in Awrangabad by the successors of its Mughal Sufis, it also provided the shrine institutions that long upheld Sufi traditions of instruction, literary composition and pilgrimage. This interdependence of Sufi and shrine reflected the economic realities of pre-industrial life; we have seen some of the troubles faced by Awrangabad's shrines as the old feudal structure of Haydarabad disappeared. Like other cultural and religious institutions associated with landownership and other pre-industrial modes of production, these links with an older economic and social system have played a large part in the difficulties which Sufism has experienced in adjusting to the modern world. Other forms of Islam born as the offspring of modernity have been more successful.

A major theme of our study has been an attempt to bring together what has often been seen as a dichotomy of 'popular' and 'elite' Sufism into an integrated picture of a cultural world that, despite its many discontinuities, was ultimately shared between different social, ethnic and intellectual groups. Despite their many other differences, men of the pen and men of the sword, rulers and peasants, shared a common dependence upon the Sufi saints and their shrines. Shrine and narrative, text and territory, were mutually dependent expressions of a broadly acknowledged Islamic cultural system. Despite more than a century of the intense cultural reformulation of both Islam and Hinduism in South Asia, it was also an enduring one. For from the seventeenth century to the present day, the royal and Sufi figures of Awrangabad's hagiographical tradition were as persistent in its architecture of the sacred as in the oral and literary traditions that as its narrative genii locii were able to quicken the city's past to life. The same patterns may be found throughout the Sufi traditions of India, tying together the memory of the region's Muslim saints, poets and kings for their mutual preservation.

Yet the relationship of the past to the present is never an automatic or unmediated one. As the modern hagiographies of Awrangabad's saints demonstrate, it is also at times a precarious transmission. Two and a half centuries of literary remembrance of the Awrangabad saints witnessed the process of memory in all its ebb and flow. For despite the perennial themes of saintly power and royal prestige in the Sufi hagiographies of Awrangabad's saints, the literary tradition that commemorated them was typified by interruptions and renewed departures as much as by simple continuity. Notwithstanding the many ruptures Awrangabad experienced with its past, the memory of the saints - sustained by their grand architectural presence - sought 
textual reification time and again. And saintly memory was forever intertwined with the remembrance of Muslim rulers. The built presence of the shrines thus provided an institutionalized aide-mémoire, ensuring that the saints would always from time to time catch the attention of regional antiquarians or literary-minded devotees, as well as that of the ordinary residents of the city. But despite the eventual recognition of Nizām al-dīn's pre-eminence both by Awrangabad's residents and by saintly memorialists from other parts of India, it was Shāh Nūr who remained closer to the hearts of the city's pilgrims. As in Sabzawārī's description from the late eighteenth century, in practice at the end of the twentieth century it was Shāh Nūr's shrine and annual festival that remained the most popular.

Although subsequently transformed into saints in reflection of the establishment of Awrangabad as the capital city of a new regional power under Nizām al-Mulk, the destiny of the Sufis' posthumous cults was forever linked with the constituencies that had been established during and shortly after their own lifetimes. The flourishing of a Sufi cult was often a partisan affair and the saints required the constant support of a body of followers over time, the more influential, lettered and wealthy the better. As the differing success of the cults of Nizām al-dīn and Shāh Musāfir shows, connections to prominent and literate Sufi circles in other cities were also of crucial importance in tying local memory into the wider cultural ecumene of Indian Islam. This cultic requirement for recognition and the patronage and validation that came with it was reflected in the associations that were made on both a factual and imaginative level between Awrangabad's saints and kings. In the end it was only the dual memory of the city's two 'Nizāms' - the sobriquets of both its premier royal and saintly citizens - that would afford Awrangabad any measure of enduring fame beyond its walls, along with the verses of the poets who in the eighteenth century gathered at the rival 'courts' (dargābs) of the city's Sufis and princes. Given the roles that saints and kings have played as the axes lending structure to the historical memory of Indian Islam, the names of Awrangabad's two great citizens provide an appropriate insight into the cultural world they inhabited, with the saint bearing the title of 'order of the faith' (Nizām al-dīn) and the prince that of 'order of the kingdom' (Nizām al-Mulk). Supporting both of these pillars of memory, however, were the shrines, books and spoken tales that we have examined in the previous chapters.

As the tangible imprint of the past, the shrines of the Sufi saints formed a means of bridging the gap between past and present time. But whether communicated through pilgrimage manuals and legends or through the more opaque language of architecture and ritual, the past that was transmitted at Awrangabad's shrines was often a disjointed one, a clamour of different histories: royal and proletarian, local and cosmopolitan, individual and collective, Muslim and Hindu. It was through this entanglement of different pasts that the shrines were able to achieve their role as repositories of history that has contributed in great measure to their sacredness. The collective act of veneration that we know as sainthood may itself be seen as a strategy of cultural memory. Rendered permanent through their transformation from flesh into stone, the Sufis of late Mughal Awrangabad created a new sacred geography in the Deccan. While for a few brief decades there hung the possibility that individually 


\section{CONCLUSIONS}

(as in Gulbarga) or collectively (as in Khuldabad) their shrines might rise to challenge the Deccan's pre-existing sacred Muslim geography, in the end their ascent was to falter, and as Awrangabad's own fortunes declined so did their own. To this extent, the change in fortunes of the Awrangabad saints was as much an expression of urban expansion and decline as it was an expression of their own individual spiritual eminence; once again the pattern is typical. But as the fortunes of the shrines were tied to that of their city, so in turn were the fortunes of scores of dervishes, poets and devotees tied to the destiny of the shrines. From hosting friends and lovers in their pleasure gardens or the carnivals that accompanied the saints' spiritual weddings to blessing the city's new-born or receiving the bodies of its dead in their cemeteries, the shrines of Awrangabad's Sufi saints accommodated the full spectrum of human activity. It is here that the traditions of the Sufis find their proper humanity, and their home in the cultural history of Islam. 


\section{GLOSSARY}

\begin{tabular}{|c|c|}
\hline Barakat & 'blessing, abundance', the sacred power of the saints \\
\hline Dhikr & $\begin{array}{l}\text { 'remembrance [of God]', the ritual chanting of the } \\
\text { Sufis }\end{array}$ \\
\hline Faqū $r$ & 'poor man', a mendicant, a Sufi \\
\hline Khalīfa & $\begin{array}{l}\text { 'successor, lieutenant', one of the deputies appointed by } \\
\text { a Sufi master }\end{array}$ \\
\hline Khānaqāh (also khānagāh) & a residence of Sufis, a Sufi lodge \\
\hline Mahfil-e-samā' & a Sufi musical gathering \\
\hline Malfīzāt & $\begin{array}{l}\text { 'speeches', a literary genre claiming to present the } \\
\text { spoken words of a saint }\end{array}$ \\
\hline Mathnawi & a poem in rhyming couplets \\
\hline Murīd & 'aspirant', a Sufi disciple \\
\hline Mursbid & 'rightful guide', a Sufi master \\
\hline$N a d h r$ & $\begin{array}{l}\text { an offering or gift in cash or kind given to a saint or } \\
\text { shrine and dedicated to God }\end{array}$ \\
\hline Panchakkī & $\begin{array}{l}\text { 'water-mill', name of the shrine of Shāh Musāfir and Shāh } \\
\text { Palangpōsh in Awrangabad }\end{array}$ \\
\hline Qalandar & $\begin{array}{l}\text { an antinomian Sufi mendicant; member of the Qalandar } \\
\text { Sufi order }\end{array}$ \\
\hline Razākār & $\begin{array}{l}\text { name of a short-lived Muslim paramilitary group in } \\
\text { Haydarabad }\end{array}$ \\
\hline Sajjäda nashīn & $\begin{array}{l}\text { 'one who sits on the prayer rug', the spiritual (and often } \\
\text { also biological) heir of a Sufi saint }\end{array}$ \\
\hline Sayyid & a descendant of the Prophet Muhammad \\
\hline Silsila & 'chain, line of succession', a Sufi lineage or royal dynasty \\
\hline Tadbkira (pl. tadbkirāt) & $\begin{array}{l}\text { 'memory, remembrance', biographical memoir, } \\
\text { hagiography }\end{array}$ \\
\hline Takiyya & 'pillow, place of repose', a Sufi lodge \\
\hline Tariqqat (pl. turuq) & 'way, path', the Sufi path, a particular Sufi order \\
\hline Tasawwuf & $\begin{array}{l}\text { 'to wear wool', Sufism, one of the learned sciences of } \\
\text { Islam }\end{array}$ \\
\hline
\end{tabular}


'Ulam $\bar{a}$

'Urs (pl. 'arās)

Wazīr
'Learned Ones', representatives of Shari' $a$ and other normative traditions of Islam

'wedding', death anniversary of saint celebrated as his wedding with God

'one who bears the burden [of government]', a vizier 


\title{
NOTES
}

\author{
PREFACE
}

1 Khāksār Sabzawārī, Sawānih (henceforth Saw) (Asiatic Society of Bengal, Curzon Collection, ms 85), f. 37r. The description is of the Awrangabad Sufi, Shāh Nūr.

2 See L. Massignon, 'Les Saints musulmans enterrés à Baghdad', Révue de l'Histoire des Religions, 58, 2 (1908) and C. Robinson, 'Prophecy and holy men in early Islam', in J. Howard-Johnston and P.A. Hayward (eds), The Cult of the Saints in Late Antiquity and the Middle Ages (Oxford: Oxford University Press, 1999). The disassociation of Sufism from saintly practices was most influentially expressed by A.J. Arberry, Sufism: An Account of the Mystics of Islam (London: George Allen and Unwin, 1950) and J.S. Trimingham, The Sufi Orders in Islam (Oxford: Clarendon Press, 1971).

3 See the classic early work on Muslim saints of I. Goldziher, 'Veneration of Saints in Islam', in S.M. Stern (ed.), Muslim Studies, vol. 2 (London: George Allen \& Unwin, 1966 (1901)). For recent critiques of older approaches, see J.J. Elias, 'Sufi Saints and Shrines in Muslim Society', Muslim World, 90, 3 and 4 (2000) and N.S. Green, 'Emerging Approaches to the Sufi Traditions of South Asia: Between Texts, Territories and the Transcendent', South Asia Research, 24, 2 (2004).

4 On Tirmidhî's formative text on sainthood, see B. Radtke and J. O'Kane, The Concept of Sainthood in Early Islamic Mysticism (London: Curzon, 1996).

5 For recent studies of the Islamic transformation of this earlier saintly landscape, see Y. Frenkel, 'Baybars and the Sacred Geography of Bilād al-Shām: A Chapter in the Islamization of Syria's Landscape', Jerusalem Studies in Arabic and Islam, 25 (2001) and E.S. Wolper, 'Khidr, Elwan Celebi and the Conversion of Sacred Sanctuaries in Anatolia', Muslim World, 90, 3 and 4 (2000).

6 See J.A. Pitt-Rivers, The People of the Sierra (Chicago, IL: University of Chicago Press, 1971), pp. 189-201. Cf. Peter Brown's classic article, 'The Rise and Function of the Holy Man in Late Antiquity', Journal of Roman Studies, 61 (1971).

\section{MUSLIM MYSTICS IN AN AGE OF EMPIRE: THE SUFIS OF AWRANGABAD}

1 Saw, f. 26r.

2 On Malik 'Anbar, see D.R. Seth, 'Life and Times of Malik Ambar', Islamic Culture, 31 (1957). On Awrangabad's history, see D.R. Amladi and P.N. Narkhede, Aurangabad: Queen of the Deccan (Bombay: Government of Maharashtra, n.d.) and S. Ramzan, Medieval Aurangabad: A Cultural Study (unpubl. PhD dissertation, Marathwada University, 1982).

3 On the Mughal conquest of the Deccan, see S. Chandra, 'The Deccan Policy of the Mughals (1) - Up to Shah Jahan' and 'The Deccan Policy of the Mughals (2) - Under Aurangzeb', in S. Chandra, Essays on Medieval Indian History (Delhi: Oxford University Press, 2003). 
4 One poignant insight into a lost world of now silent defiance is provided by the English ambassador Norris, staying in Masulipatam in 1700-1, who heard jubilant rumours of the escape of the imprisoned king of Golkonda Abü'l Hasan, noting the distress of the king's former subjects. See H. Das, The Norris Embassy to Aurangzib (Calcutta: Firma K.L. Mukhupadhyay, 1959), pp. 160-1. The Italian traveller Manucci recorded how the Marathas urged revolt by spreading rumours of Abū'l Hasan's escape from Dawlatabad. See N. Manucci, Storia do Mogor or Mogul India, 1653-1708, trans. W. Irvine (London: John Murray, 1907-8), vol. 3, p. 192.

5 Sādik Isfahānī, The Geographical Works of Sādik Isfahāni, ed. and trans. Sir William Ouseley (London: John Murray, 1832), p. 47. Modern scholars generally conclude that this early name referred rather to the hard ground of the region.

6 S.N. Sen (ed.), Indian Travels of Thevenot and Careri (Delhi: National Archives of India, 1949), pp. 103-4.

7 See Shīr 'Alī (Afsūs), Araish-i-mahfil; or, The Ornament of the Assembly, trans. H. Court (Allahabad: Pioneer Press, 1871), p. 102. Afūs seems to have copied this description from an earlier historical work by Munshī Sujān Rāī of Patiala, though he may also have visited the city on his way to Haydarabad.

8 S.H. Bilgrami and C. Willmott, Historical and Descriptive Sketch of His Highness the Nizam's Dominions, 2 vols (Bombay: Times of India Steam Press, 1883-4), pp. 312 and 315. By comparison, the population of Delhi a few decades earlier has been estimated at some 375,000-400,000. See S.P. Blake, Shabjahanabad: The Sovereign City in Mughal India 1639-1739 (Delhi: Cambridge University Press, 1993), p. 67.

9 S. Digby, 'The Naqshbandīs in the Deccan in the Late Seventeenth and Early Eighteenth Century A.D.: Bābā Palangposh, Bābā Musāfir and Their Adherents', in M. Gaborieau, A. Popover and T. Zarcone (eds), Naqshbandīs: Cheminements et situation actuelle d'un ordre mystique musulman (Istanbul: Isis Press, 1990), pp. 175-6. Other suburbs included Begampūrā, Qutbpūrā, Bājīpūrā and Jingapūrā.

10 Das (1959), p. 244.

11 On North Indian economic and political decline, see M. Alam, The Crisis of Empire in Mughal North India: Awadh \& the Punjab 1707-1748 (Delhi: Oxford University Press, 1997).

12 On the career of Nizām al-Mulk, see Y. Husain, The First Nizam: The Life and Times of Nizāmu'l-Mulk Āsaf Jāh I (London: Asia Publishing, 1963) and M.A. Nayeem, Mughal Administration of Deccan Under Nizamul Mulk Asaf Jah (1720-48 AD) (Delhi: Jaico Publishing, 1985); and of Walī, see J.A. Haywood, 'Wali Dakhani and the Development of Dakhani-Urdu Sufi Poetry', Acta Orientalia, 28, 1-2 (1964).

13 On Sufism in the Deccan, see K.A. Nizami, 'Sufi Movement in the Deccan', in Sherwani and Joshi (eds) (1973-4) and M.S. Siddiqi, The Babmani Sufis (Delhi: Idarah-i Adabiyat-i Delli, 1989).

14 C.W. Ernst, Eternal Garden: Mysticism, History, and Politics at a South Asian Sufi Center (Albany, NY: State University of New York Press, 1992).

15 Shāh Mahmūd Awrangābādī, Malfūzāt-e-Naqshbandiyya: Hālāt-e-Hazrat Bābā Shāh Musāfir Sāhib (Haydarabad: Nizāmat-e-'Umūr-e-Madhhabī-e-Sarkār-e-'Ālī, 1358/1939-40), henceforth MN. The text has been translated by Simon Digby as Sufis and Soldiers in Aurangzeb's Deccan (Delhi: Oxford University Press, 2001). However, all page references refer to the Persian edition.

16 For example, $M N$, pp. 22, 24, 35, 41-3. Mughal sources show the levels of continued immigration into the Mughal realm during the reign of Awrangzeb. See Kewal Ram, Tazkiratul-Umara of Kewal Ram, trans. S.M. Azizuddin Husain (Delhi: Munshiram Manoharlal, 1985) and M. Athar Ali, The Mughal Nobility Under Aurangzeb (London: Asian Publishing House, 1966). As Digby points out, immigration apparently increased during the seventeenth century as the decline of the Üzbek kingdoms was pitched into ever starker contrast with the expanding Mughal imperium to the south. See S. Digby, Before 
the Bābās Came to India: A Reconstruction of the Earlier Lives of Bābā Sa'īd Palangpōsh and Bābā Muhammad Musāfir in "Wilāyat"', Iran, 36 (1998), pp. 152-3.

17 For example, $M N$, pp. 17, 22, 31, 74 .

$18 M N$, pp. 34-5 and 24 respectively. Such episodes form a large proportion of the text.

19 Kāmgār Khān, Ashān al-shamā'il (Malfüzāt-e-Shāh Nizām al-dīn Awliyā Awrangāāād̄̄) (henceforth AS) (ms, Tawnsa Shrine Library, Tawnsa Sharif, Pakistan), p. 70.

20 See Nizām al-dīn Awliyā Awrangābādī, Nizām al-qulūb (henceforth Nizam) (Delhi: Matba'a-ye-Mujtabā'ī, 1309/1891-2) and Shāh Kalīm Allāh Jahānābādī, Kashkūl, ms, Salar Jung Library, Hyderabad, Tas. 130 (henceforth Kashkül), f. 9v, 27r, 37v.

21 Shah Nawaz Khan, Ma'āthir al-umarā (henceforth $M U$ ), trans. H. Beveridge, revised by B. Prashad (Calcutta: Asiatic Society of Bengal, 1911-52), pp. 476-7. On this family relationship, which contributes considerably to the credibility of Shāh Nawāz's account of Shāh Nūr, see T.W. Beale, The Oriental Biographical Dictionary (Calcutta: Asiatic Society of Bengal, 1881), pp. 247-8.

22 Nür al-anwār (henceforth NA), an Urdu translation of the parts of Khizān $\bar{u} b a b \bar{a} r$ of Bāhā' al-dīn Hasan 'Urūj related to Shāh Nūr, by Zahūr Khān Zahūr (ms, Collection of Mohammad Abd al-Hayy, Awrangabad), p. 1 and $M U$, p. 476.

$23 N A$, p. 1.

24 NA, p. 6. Both hujra and mosque survive today.

25 Qutbpūra maintained its association with the administrative and officer classes of the city under Āsaf Jāh rule well into the twentieth century.

$26 N A$, pp. 2 and 13-16. An earlier date of 1102/1690 is also given in the same document (p. 30), leading to confusion by Shāh Nūr's later Urdu biographers, though the eighteenth-century memorialist Sabzawārī confirms the later date. See Saw f. 38r.

27 MN, p. 17. The date of Shāh Musāfir's arrival is based on the chronology established by Digby (1998).

28 Kewal Rām referred to this Diyānat Khān in his Tadhkirat al-Umarāa (Kewal Ram, 1985, p. 67), while he was also described by the main chronicler of Awrangzeb's reign, Khāfí Khān, and the English ambassador Norris. The history of his family is dealt with at length in $M U$, pp. 12-14, 475-83.

$29 M U$, pp. 475-83; NA, pp. 3, 15.

$30 M U$, p. 476.

$31 M N$, p. 164. I am grateful to the biographical notes in Digby (2001, pp. 251-71) for clarifying these identifications.

32 NA, pp. 9, 14. Muhammad Ikrām is mentioned several times in the Ma'āthir-e-'A $\operatorname{l}$ lamgì $\bar{\imath}$. See Saqi Must'ad Khan, Mā̄sir-i-'Ālamgīrī, trans. J.N. Sarkar (Calcutta: Asiatic Society of Bengal, 1990), pp. 146, 239, 241. The later Deccan historian and tadhkira-writer Malkāpūrī, whose scholarship was generally reliable, confirms these names and titles, detailing their own and their descendants' careers in the Āsaf Jāh state administration. See 'Abd al-Jabbār Khān Malkāpūrī, Mahbūb-e-Dh̄̄'l-minan: Tadhkira-ye-Awliyā-yeDakan (henceforth Tadh) (Hyderabad: Hasan Press, 1331/1912), pp. 1104-6.

33 NA, p. 15. The name of this wife was given as Nawāba Baìjīi.

$34 N A$, p. 1. There is a Shi ${ }^{i} \mathrm{i}$ air throughout the $N A$, not least in a number of Shi $\mathrm{i}$ expressions put into the mouth of Shāh Nūr himself.

35 N.S. Green, 'Shi' ism, Sufism and Sacred Space in the Deccan: Counter-Narratives of Saintly Identity in the Cult of Shah Nur', in A. Monsutti, S. Naef and F. Sabahi (eds), The Other Shi' ites (London: I.B. Tauris, forthcoming).

$36 M U$, p. 476. The same name was given in the $M N$ (p. 91), whose author was a younger contemporary of Shāh Nūr and may have known him as a child, as well as the Makbzan al-a'rās (c.1155/1742-3, drawing on an earlier version written in Awrangabad before $1142 / 1729$, p. 59) and Saw (c.1188/1774, f. 37r-38r).

37 Saw, f. 37 r. 
38 K.K. Muhammad, 'The Houses of the Nobility in Mughal India', Islamic Culture, 60 (1986), p. 101.

39 A. Schimmel, 'A Dervish in the Guise of a Prince: Khān-i Khānān 'Abdur Rahīm as a Patron', in B. Stoler-Miller (ed.), The Powers of Art: Patronage in Indian Culture (Oxford: Oxford University Press, 1992), p. 209.

40 With regard to the architecture of Mughal sub-imperial palaces, the political symbolism of several prominent hammāms, which were sometimes larger than neighbouring mosques, has been discussed by C.B. Asher, 'Sub-Imperial Palaces: Power and Authority in Mughal India', Ars Orientalis, 23 (1993), pp. 284-7.

41 NA, pp. 5, 1. This text was written $c .1183-4 / 1770$.

$42 M U$, p. 476.

$43 N A$, p. 5. The same text also mentions another initiation in Madina by Sayyid Shihāb al-dīn Qibla (p. 2), though such multiple initiations were common at this time.

44 Muhammad Najīb Qādirī Nagawrī, Kitāb-e-a'rās (Makbzan-e-a'rās) (henceforth A'rās) (Agra: n.p., 1300/1883), p. 59.

$45 M U$, p. 476.

$46 M U$, p. 476.

47 AS, p. 97.

48 Tadbkira-ye-Riyāz Husayñ̄: Mardān-e-Āftāb 'Ālamtāb-e-Man (henceforth RH), trans. into Urdu by A.M. Beg (Awrangabad: Mahāvīr Pīr, 1994), pp. 26-7 (Urdu).

49 The math survives today and preserved there are two early miniatures of Shāh Nūr and Mānpūrī.

$50 R H$, pp. 26-7. A wider selection was also published (in Devanagiri script) some years ago in Awrangabad. These bhajans are still regularly performed at Mānpūrìs math at Dawlatabad.

51 N. Manucci, A Pepys of Mughal India (1653-1708) (Delhi: Srishti Publications, 1999), pp. 81-2.

52 For earlier studies of Shāh Palangpōsh and Shāh Musāfir to which I am much indebted, see Digby $(1990,1998)$.

53 The shrine of "Abd al-Khalīq (d. 575/1179-80) at Ghijdawan at times rivalled even that of Bahā' al-dīn Naqshband in importance, while the $M N$ (p. 3) adds that the shrine of Bābā Qul Farīd, the murshid of Shāh Palangpōsh, was also located in Ghijdawan and resorted to by the city's inhabitants.

54 The chronology of their pre-Awrangabad lives has been ingeniously reconstructed by Digby (1998).

55 On other contemporary Central Asian travellers in India and their accounts of their own often picaresque adventures, see R. Foltz, Mughal India and Central Asia (Karachi: Oxford University Press, 2001), pp. 106-26.

56 Mawlānā Qamar al-dīn, Nūr al-Karīmatayn (Kanpur: Matba'a-ye-Nizāmīi, 1307/1889) and Hādī Naqshbandī, Rūh al-'Ināyat (Burhanpur: Rashīd Buk Dīpō, 1417/1996) (Urdu).

57 Digby (1998), pp. 150-2. On the relative fortunes of the Naqshbandī and Kubrāwī orders in Shāh Musāfir's homeland, see D. DeWeese, 'The Eclipse of the Kubraviyah in Central Asia', Iranian Studies, 21 (1988).

$58 M N$, p. 10. In his short account of Shāh Musāfir in his Ma'āthir al-kirām, Āzād Bilgrāmī (d. 1200/1786) claimed that this period of teaching lasted some twelve years. See Ghulām 'Alī Āzād Bilgrāmī, Ma'āthir al-kirām (henceforth $M K$ ) (Agra: Matba'a-ye-Mufīd-e-'Ām, 1328/1910), p. 174.

59 Digby (1998), pp. 159-60.

$60 M N$, p. 17. The site of this takiyya, described as 'near to Qutbpūrā', was certainly close to and may well have been identical with the site of the shrine of Shāh Nūr.

$61 M N$, pp. 21-3. Shāh Musāfir later made a pilgrimage to the shrine of Shāh Nūr, who had died in $1104 / 1692(M N$, p. 91$)$.

$62 M N$, p. 109. 
63 Cf. the description of the 'military pīr' elsewhere in the Deccan in R.M. Eaton, Sufis of Bijapur, 1300-1700: Social Roles of Sufis in Medieval India (Princeton, NJ: Princeton University Press, 1978).

64 See C. Walter, The Warrior Saints in Byzantine Art and Tradition (Oxford: Oxford University Press, 2003) and D.N. Lorenzen, 'Warrior Ascetics in Indian History', Journal of the American Oriental Society, 97 (1978).

65 For example, $M N$, pp. 8, 25-6, 40-1, 102.

$66 M N$, pp. 15-16. It is also claimed that Shāh Palangpōsh later saved the life of Awrangzeb himself during such a campaign when crossing a river in flood with his army ( $M N$, p. 7).

67 MN, pp. 40-1

$68 M N$, p. 35-6.

69 MN, p. 28.

70 Such a sartorial pelt was known as a palangina or babr bayān. An illustration from a Shābnamah painted at Tabriz around 911/1505 shows the ancient Persian ruler Rustam wearing both a tiger and leopard skin into battle. The animal-skin, preferably the pelt of a big cat, was long to remain the favoured garment of antinomian dervishes, and travellers reported the existence of shops in Persia selling these and other dervish accoutrements to would-be Sufi mendicants well into the nineteenth century.

71 Bhimsen, Tarikh-i-dilkasha (Memoirs of Bhimsen Relating to Aurangzib's Deccan Campaigns), trans. J. Sarkar (Bombay: Dept. of Archives, Govt. of Maharashtra, 1972), p. 159.

72 Saqi Must'ad Khan (1990), pp. 196-7.

73 Saqi Must'ad Khan (1990), pp. 196 and 287.

$74 M N$, p. 37.

$75 M N$, p.26. On Shāh Palangpōsh's earlier martial career, see $M N$, pp. 5-6, 15-16. On the similar military roles of shamans and Sufis in Central Asia, see J. Baldick, Animal and Shaman: Ancient Religions of Central Asia (London: I.B. Tauris, 2000).

76 MN, p. 37.

77 On Shāh Palangpōsh's meeting with Khizr and hunting of the leopard (also referred to as a lion), see $M N$, p. 4. DeWeese has noted similar narratives associated in sixteenth and seventeenth-century accounts of the great Central Asian saint Ahmad Yasawī. See D. DeWeese, "Sacred Places and "Public" Narratives: The Shrine of Ahmad Yasavī in Hagiographical Traditions of the Yasavī Sufi Order, 16th to 17th Centuries', Muslim World, 90, 3 and 4 (2000). The title palangpōsh also possessed a less serious (and doubtless unintended) side as the name of a popular variety of colourful bedding-cloth produced in the Deccan and elsewhere.

$78 M N$, pp. 112, 136.

$79 M N$, pp. 20-1. It is hard not to sense a residue of hard feeling and rivalry in this description of the behaviour of the follower of one master by the successor of another.

$80 M N$, p. 101.

81 For example, $M N$, pp. 35-6.

82 MN, pp. 88-9. See also Digby (1990).

$83 M N$, pp. 22, 74-5, 114. This seems to prefigure the role of many shrines as centres for the cure of mental illness.

$84 M N$, p. 113. There was competition in this business, however, for Nizām al-dīn was to grant a similar miraculous request during a drought in the Deccan city of Sholapur (AS, p. 47).

85 MN, pp. 68-9.

86 MN, pp.34-5. Cf J. Gross, 'Multiple Roles and Perceptions of a Sufi Shaikh: Symbolic Statements of Political and Religious Authority', in Gaborieau et al (1990).

87 MN, pp. 105-6.

$88 M N$, pp. 104-5.

89 For example, $M N$, pp. 22, 62-3, 120. Often these followers held high positions in the state, including apparently the post of sübedār of Delhi (MN, p. 129), while other 
followers may have been involved in the politics of imperial succession after the death of Awrangzeb (MN, pp. 116-17).

90 See A. Schimmel, Islam in India and Pakistan (Iconography of Religions XXII, 9) (Leiden: E.J. Brill, 1982), p. 32 and plate XLIIIb.

$91 M N$, p. 115.

$92 M N$, pp. 4, 26, 28.

$93 M N$, p. 72.

$94 M N$, p. 105.

$95 M N$, pp. 86-8. Similar oral traditions regarding the other Awrangabad saints are described in Chapter 5.

96 S. Digby, 'Anecdotes of a Provincial Sufi of the Delhi Sultanate, Khwāja Gurg of Kara', Iran, 32 (1994), p.105.

$97 M N$, p. 73.

$98 M N$, p. 107. This was perhaps small change compared to the broader income of the takiyya, and one of its residents alone is described as being the recipient of an imperial pension of some 7,000 rupees ( $M N$, p. 115).

$99 M N$, pp. 129 and 81 respectively.

100 For example, $M N$, pp. 53, 73-4, 89, 107, 117, 121.

101 For example $M N$, pp. 47, 52-3, 130-1.

$102 M N$, pp. 43-4, 71-3, 143 and 37 respectively.

$103 M N$, p. 60.

104 Bilgrami and Willmott (1883-4), p. 318 and K.G. Schwerin, Indirekte Herrschaft und Reformpolitik im indischen Fürstenstaat Hyderabad, 1853-1911 (Wiesbaden: Steiner, 1980), p. 51.

105 For example, $M N$, pp. 17, 31, 38-9, 41-2, 46-7.

$106 M N$, p. 58.

$107 M N$, p. 60. On the influence of such theories of Ibn 'Arabī in India, see W.C. Chittick, 'Notes on Ibn 'Arabî's Influence in the Indian Sub-Continent', Muslim World, 82 (1992).

108 MN, p.118. On tawajjuh and other Naqshbandī techniques, see M. Chodkiewicz, 'Quelques aspects des techniques spirituelles dans la tarīqa naqshbandiyya', in Gaborieau et al. (1990). On Indian Sufi rules of etiquette, see D. Matringe, 'Ādāb al-Sūfìya: les règles de vie dans les couvents soufis de l'Inde medievale', Journal Asiatique, 289, 1 (2001).

109 Y. Friedmann, Shaykh Abmad Sirhind̄̄ (Montreal: McGill-Queen's University Press, 1971).

110 Ironically it was Shāh Kalīm Allāh, the master of Nizām al-dīn, who remarked on the presence of these Sirhindis in one of his letters to his disciple in Awrangabad (cited in Digby, 2001, p. 37). Kalīm Allāh's involvement in such sectarian disputes is also seen in his composition of a book against the Shi'a entitled Radd al-rawäfiz.

111 See also Digby (1990). On Sirhindî’s posthumous influence in Delhi, see W. Fusfeld, 'The Shaping of Sufi Leadership in Delhi: The Naqshbandiyya-Mujaddidiyya, 1750-1920' (unpubl. PhD dissertation, University of Pennsylvania, 1981).

112 Friedmann (1971), pp. 94-5. The original text of this decree, preserved in the Ma'arij al-wilāya (1094/1683) of 'Abd Allāh Khwēshgī Qasūrī, has been published by Friedmann as Appendix B (p. 118).

113 Ibid., pp. 95-101.

114 Ibid., pp. 7-8.

115 Ibid., p. 8.

116 For brief earlier appraisals of Nizām al-dīn, see S.A.A. Rizvi, A History of Sufism in India, 2 vols (Delhi: Munshiram, 1978-83), vol. 2, pp. 304-5 and M.Z. Siddiqui, art. 'Awrangābādī, Shah Nezām-al-dīn', in Encyclopaedia Iranica (henceforth EIr).

117 On dates, see Siddiqui in EIr. The earlier date sometimes quoted of 1060/1650 draws on the late Khātim-e-Sulaymāñ $(1325 / 1907)$ of Mawlānā Allāh Bakhsh. 
118 For example, Sir Sayyid Ahmad Khān, Āthār al-Sanādìd (henceforth Āthār) (Delhi: Matba'a Sayyid al-Akhbār, 1263/1846) and Tadh.

119 On Shāh Kalīm Allāh, see Rizvi (1978-83), vol. 2, pp. 296-304 and M. Umar, Islam in Northern India During the Eighteenth Century (Delhi: Munshiram Manoharlal, 1993), pp. 50-69, and on Yahyā Madan̄ see Rizvi (1978-83), vol. 2, pp. 296-8 and 345-6. The former, perhaps the most influential Chishtī figure of his day, left several important texts, including a Kashkül-e-Kalīmī and a collection of letters (Maktübāt). Chittick (1992) has described him as one of the most important transmitters of the thought of Ibn 'Arabi in India.

120 This order is recorded in a letter to Nizām al-dīn preserved in Kalīm Allāh's maktūbāt. See Shāh Kalīm Allāh Jahānābādī, Maktūbāt-e-Katīmī (henceforth Maktūbāt) (Delhi: Matba'a-e-Yūsufī, 1301/1884), p. 26.

121 D. Prasad, Saints of Telangana (Hyderabad: Abul Kalam Azad Oriental Research Institute, 1969), pp. 8-12.

$122 A S$, p. 70.

123 Maktūbāt, pp. 53, 58.

124 AS, p. 59.

125 Sabzawāīi (Saw, f. 35r), writing a few decades after Nizām al-dīn's death, provided the earliest surviving textual evidence for this association.

126 The book must now be presumed lost, since neither the searches of the present writer nor those of S.A.A. Rizvi and K.A. Nizami have succeeded in tracing a copy. No reference is made to it in M. Fathullah Khan, 'The Nizams as Men of Letters', Islamic Culture, 12, 4 (1938). However, when Mawlawī Rahīm Bakhsh was writing his Shajārat al-anwār, he reportedly saw the book in the house of Hajī Wāsil, the deputy (khalīfa) of Nizām al-dīn's son, Fakhr al-dīn. See K.A. Nizāmī, Tārīkh-e-Mashā'ikh-e-Chisht (Delhi: Idāra-yeAdabiyyat-e-Dillī, 1980-5), p.453.

127 P.S.M. Rao, Eighteenth Century Deccan (Bombay: Popular Prakashan, 1963), pp. 81, 85-6, 95, 112-13, 120-1. At the centre of many currents of eighteenth-century Sufism, Nizām al-Mulk also exchanged letters with Shāh Walī Allāh. See R. Kumar, 'Political Letters of Shah Wali Ullah', in R. Kumar (ed.), Survey of Medieval India, vol. 9, Nadir Shab and Anarchy India (Delhi: Ammol Publications, 1999).

128 'Imād al-Mulk Ghāzī al-dīn Khān, Mathnawī-ye-fakhriyyat al-nizām, ms, 92-3 and 136-7. I have consulted a copy held at the shrine of Nizām al-dīn in Aurangabad. C.A. Storey, Persian Literature: A Bio-bibliographical Survey, 2 vols. (London: Luzac \& Co., 1927-71), p. 1030 notes that no manuscripts of this work are known in public collections. Awrangzeb also at times interfered in such matters, as when he dismissed the sajjāda nashīn of Gīsū Darāz at Gulbarga during an early visit to the shrine. The conditions of the custodian families at the shrine in Gulbarga immediately after the conquest were described by the chronicler Bhimsen. See Bhimsen, English Translation of Tarikh-iDilkasha, trans. J. Sarkar (Bombay: Government of Maharashtra, 1972), pp. 115-16.

129 AS, pp. 68-9, 76-8, 86.

130 RH, p. 111.

131 Afzal Bēg Qāqshāl Awrangābādī, Tuhfat al-Shu'arā, ms, Salar Jung Library, Hyderabad, Tad. 8 (henceforth Tuhfa), f. 99r-102v. Qāqshāl clearly valued Wāsil's poetry highly and preserved a considerable number of his couplets.

132 The relevant sections from these anthologies are found in 'Abd al-Qādir Sarwarîs Urdu introduction to his edition of Sirāj’s poems. See Sirāj Awrangābādī, Kulliyāt-e-Sirāj, ed. 'Abd al-Qādir Sarwarī (repr. Delhi: Qawmī Kawnsil barāye Furūgh-e-Urdū Zabān, 1998).

133 See N. Hadi, Dictionary of Indo-Persian Literature (Delhi: Indira Gandhi National Centre for the Arts, 1995), p. 23.

134 Also $A S$, pp. 62, 82, 90 and $M N$, pp. 73, 124.

135 C.W. Ernst, 'An Indo-Persian Guide to Sufi Shrine Pilgrimage', in G.M. Smith and C.W. Ernst (eds), Manifestations of Sainthood in Islam (Istanbul: Isis Press, 1993), 
p. 48. This text survives, and has been consulted, in its later expanded form as the Makbzan-e-a'rās.

136 MN, pp. 72-3.

137 Nizāmī (1980-5), p. 445.

138 See B.B. Lawrence, 'The Early Chishtī approach to Samā”, in M. Israel and N.K. Wagle (eds), Islamic Society and Culture (Delhi: Munshiram, 1983).

139 AS, pp. 64, 74, 79-81, 84, 93-7, 113-14, 116-18.

140 See Nizām. For a discussion of this text, see C.W. Ernst, 'Chishtī Meditation Practices of the Later Mughal Period', in L. Lewisohn and D. Morgan (eds), The Heritage of Sufism, vol. 3, Late Classical Persianate Sufism (1501-1750) (Oxford: Oneworld, 1999).

141 Kashkül, f. 35r and 35v.

142 AS, p. 97.

143 'Imād al-Mulk Ghāzī al-dīn Khān Fīrōz Jang III, Manāqib-e-Fakhriyya, ms, Salar Jung Library, Hyderabad, T-S. 31, f. 6r.

144 This relies on the usually well-informed late source Malkāpūrī (Tadh, p. 1100), who detailed all of these marriages. A more recent biography also recounts a tradition that one of Nizām al-dīn's sons migrated to Calcutta where his descendants still reside, a detail summing in all its brevity the poignancy of Indian history in the eighteenth century. See Sayyid Hasan, Hālāt $\bar{u}$ Zindagì-ye-Nizām al-dīn Awliyā Awrangābād $\bar{\imath}$ (henceforth Hasan) (Awrangabad: n.p., n.d.), p. 19.

145 Kalīm Allāh's grandfather Mawlawī Ahmad (known as Nādir al-'Asr) was one of the greatest architects of the reign of Shah Jahan, while his father Hajī Nūr Allāh designed the calligraphy on the front of Shah Jahan's Friday Mosque in Delhi.

146 The emperor Humayun's wife Hamida came from the family of the great Khurasani saint Ahmad-e-Jām (d. 536/1141), while members of the Safawi royal house of Iran had made strategic marriages with the Ni'mat Allāhī Sufi family; the family of the Durrani rulers of Afghanistan similarly intermarried with the Naqshbandī Sufis of Kabul.

147 Z. Malik, The Reign of Muhammad Shah, 1719-1748 (Bombay: Asia Publishing House, 1977), p. 393, drawing on the Takmila of Gul Muhammad Ahmadpūrī. It is impossible to resist recounting a Deccani tradition describing how a Sufi might put such knowledge of the arts of war to good use. For it is said that like Fakhr al-dinn, the famous Haydarabadi saint Husayn Shāh Walī of Golkonda (d. 1068/1658) had also studied the arts of war and was an expert archer and marksman. Thus it was that one day, in procession with the ruler of Golkonda, a kite suddenly shat upon the king from a tremendous height, to which lèse majesté the Sufi promptly replied by instantaneously shooting the bird down from the high heavens with his musket (Prasad, 1969, p. 16, drawing on oral tradition). A version in which the saint kills the offensive kite merely through his glance (nazr-e-jalāl) was recorded in the nineteenth century in Ghulām 'Alī Qādirī, Mishkat al-Nubuwwat (Haydarabad: A'jāz Printing Press, 1982), vol. 6, p. 155.

148 'Imād al-Mulk, Manāqib-e-Fakhriyya, f. 7v-10r.

149 Ibid., f. 14v-15r. S.A.A. Rizvi, Shāh Wal̄ Allāh and his Times (Canberra: Ma rifat Publishing House, 1980, p. 373) claims that Fakhr al-dinn went to Delhi in order to fill the gulf in Chishtī leadership created by the death of Kalīm Allāh, while Umar (1993, p. 137) has argued that the dangers caused by the Marathas in the Deccan were the most probable reason for his departure. Given the chronology of the departure around seventeen years after Kalīm Allāh's death, the deteriorating security of Awrangabad seems likely to have been the more pressing factor.

$150 A S$, pp. 47-9, 85, 90 and pp.105-6 respectively.

151 AS, pp. 62, 82, 90. See also Ernst (1992) on the Khuldabad malfüzāt.

152 The date of the composition of the $M N$ seems to have been over a period of years up to around $1162 / 1750$, since a poem by Bilgrāmī written in praise of the completion of the tank around this time is included (MN, p. 112). Much of the text, however, seems to have been written earlier, its first sections not even by the main author Shāh Mahmūd but by an earlier 
biographer several decades earlier. It seems likely therefore that the text was composed periodically over an extended period. I am grateful to Simon Digby for helping clarify this chronology. The dating of the Absan al-shama'il to 1156/1743 is based on the information contained in the colophon, recording its composition by Kāmgār Khān in that year.

$153 M N$, pp. 31-2. On Central Asians and falconry in India, see Foltz (2001), pp. 63 and 86.

$154 M N$, passim, especially pp. 22, 40-1, 86-8. The association of the Naqshbandiyya and the followers of the Mughals is also attested in a letter to Nizām al-dīn from his master Kalīm Allāh, where the latter writes that the Tūrānīs are exclusively attached to the Naqshbandiyya. See Maktūbāt, pp. 67, 90.

155 Tuhfa, f. 110r-110v.

156 Salar Jung Catalogue of Persian Manuscripts (Hyderabad: Salar Jung Museum, 1965), vol. 13, pp. 216-17.

157 The Manāqib-e-Chishtiyya is referred to in AS, pp. 47 and 90, while stories of Mu'inn al-dīn (e.g. p. 97), Nasīr al-dīn Mahmūd (e.g. p. 47), Qutb al-dīn Bakhtiyār Kākī (e.g. pp. 48, 85, 90), Farīd al-dīn Ganj-e-Shakar (e.g. p. 85) and Mīr Sayyid Qanawjī (e.g. pp. 65-70, 86, 90), for whom Nizām al-dīn seems to have had a special respect, recur throughout the text.

158 Digby (1990), p. 170. The Rashahāt-e-'ayn al-bayāt of Kāshifī (d. 939/1532) on the great Naqshbandī shaykhs of Central Asia, especially Khwāja Ahrār, was completed in 909/1503, while the Nafahāt al-uns of Jāmī was completed some time before the author's death in 898/1492. For a study of the latter, see J. Mojaddedi, The Biographical Tradition in Sufism: The Tabaqat Genre from al-Sulami to Jami (London: Curzon, 2001), pp. 151-76.

159 O.F. Akimushkin, 'A Rare Seventeenth Century Hagiography of the NaqshbandiyyaMujaddidiyya Shaykhs', Manuscripta Orientalia, 7, 1 (2001), p. 63.

160 On the transformation of the shrine of Mu'min 'Ârif at Dawlatabad outside Awrangabad from Shi' ism to Sunnism, see Ernst (1992), p. 234.

161 Cf. S.S. Alvi, 'Qāzī Sanā’ Allāh Pānpatī, An Eighteenth Century Indian Sūīi-'Ālim: A Study of his Writings in their Sociopolitical Context', in W.B. Hallaq and D.P. Little (eds), Islamic Studies Presented to Charles J. Adams (Leiden: E.J. Brill, 1991).

162 For example, $M N$, pp. 22, 40-1, 62-3, 70-1, 76, 78, 86-8, 102, 104-6, 116-17, 120, $122,128$.

163 An example from Akbar's court shares its generic title of majālis with Kāmgār Khān's account of Kalīm Allāh, though the arrangement of both such Sufi and courtly texts into such 'sittings' was a primary structural motif that far outweighed the value of such titular similarities. See D.N. MacLean, 'Real Men and False Men at the Court of Akbar: The Majalis of Shaykh Mustafa Gujarati', in D. Gilmartin and B.B. Lawrence (eds), Beyond Turk and Hindu: Rethinking Religious Identities in Islamicate South Asia (Gainsville, FL: University of Florida Press, 2000).

164 This section of Mansāāām's text is translated in Rao (1963), pp. 105-77.

$165 M N$, pp. 72-3. I am grateful for the notes provided in Digby (2001) for confirming the identification of the Shāh Nizām al-dīn Darwīsh of this passage with Nizām al-dīn Awrangābādī.

166 On this question of Tūrānī ethnicity, see also Digby (1990) and Foltz (2001), pp. 12-51.

167 On the discourse of travel among the Awrangabad Naqshbandīs and other Indian Sufis, see N.S. Green, 'Migrant Sufis and Sacred Space in South Asian Islam', Contemporary South Asia, 12, 4 (2003).

168 A. Husain, 'The Family of Shaikh Salim Chishti during the Reign of Jehangir', in K.A. Nizami (ed.), Medieval India - A Miscellany, vol. 2 (Delhi: Asia Publishing House, 1972) and B.B. Lawrence, 'Veiled Opposition to Sufis in Muslim South Asia: Dynastic Manipulation of Mystical Brotherhoods by the Great Mughal', in F. De Jong and B. Radtke (eds), Islamic Mysticism Contested: 13 Centuries of Controversies and Polemics (Leiden: E.J. Brill, 1999).

169 See P.M. Currie, The Shrine and Cult of Mu'in al-Dīn Chishtī of Ajmer (Delhi: Oxford University Press, 1989) and S.A.I. Tirmizi, 'Mughal Documents Relating to the Dargah of Khwaja Mu'inuddin Chishti', in Troll (1989). 
170 Khafi Khan, Muntakhab al-Lubāb: Khafi Khan's History of 'Alamgir, trans. S. Moinul Haq (Karachi: Pakistan Historical Society, 1975), pp. 78-9 and 337 and Sāqi Must'ad Khan (1990), pp. 69, 78, 98, 118, 123, 175-6. For his part, Dārā had unsuccessfully sought supernatural assistance from the shrine of Bahā' al-dīn Zakariyā at Multan. See Manucci (1999), pp. 81-2.

171 Maktūbāt, pp. 10-12.

172 AS, pp. 65-70, 102-5.

173 AS, pp. 66-70.

174 AS, pp. 62, 82, 90 .

175 On the symbolic importance of Delhi to the Chishtiyya, see S. Digby, 'Early Pilgrimages to the Graves of Mu'in al-Din and other Chishti Shaikhs', in M. Israel and N.K. Wagle (eds), Islamic Society and Culture (Delhi: Manohar, 1983).

176 Maktūbāt, p. 26.

177 Details of his life are found in the Urdu introduction to his Persian divan. See Ghulām Chishtīi, Dīwān-e-Gbulām Chishtī Illichpūrì (Ellichpur: n.p., 1420/1999). A few of the poems mention Nizām al-dīn and his master Kalīm Allāh.

178 On comparable processes in medieval Europe, see M.C. Ross, 'Land-Taking and TextMaking in Medieval Iceland', in S. Tomasch and S. Gilles (eds), Text and Territory: Geographical Imagination in the European Middle Ages (Philadelphia, PA: University of Pennsylvania Press, 1998).

179 See Y. Frenkel, 'Baybars and the Sacred Geography of Bilād al-Shām: A Chapter in the Islamization of Syria's Landscape', Jerusalem Studies in Arabic and Islam, 25 (2001) and J. Gonnella, Islamische Heiligenverehrung im urbanen Kontext am Beispiel von Aleppo (Syrien) (Berlin: Klaus Schwarz, 1995).

180 On this community, see M. Shafi'i, 'An Afghan Colony at Qusur', Islamic Culture, 3, 3 (1929).

181 The account of the Awrangabad Naqshbandīs is found in $M K$, pp. 171-4.

182 AS, p. 202.

183 See A.M. Guenther, 'Hanafi Fiqh in Mughal India: The Fatawa-i 'Alamgiri', in R.M. Eaton (ed.), India's Islamic Traditions, 711-1750 (Delhi: Oxford University Press, 2003). The main sources of this text were Hanafī textbooks composed in Central Asia. In similar vein, Awrangzeb also commissioned a copy of the Bahr al-Asrār of the Central Asian historian Mahmūd ibn Amīr Wal̄̄ (fl. 1034/1624-5).

184 Storey (1927-71), p. 856.

185 On Delhi as a rival cultural centre during this period, see S. Chandra, 'Cultural and Political Role of Delhi, 1675-1725', in R.E. Frykenberg (ed.), Delhi Through the Ages (Delhi: Oxford University Press, 1986).

186 See M. Rahman, art. 'Faq̄īr Dehlavī', in Encyclopedia Iranica.

187 On overlapping linguistic and literary change in Mughal Awrangabad, see S.R. Faruqi, Early Urdu Literary History and Culture (Delhi: Oxford University Press, 2001), pp. 138-40.

188 Bhimsen (1972), pp. 156-8.

189 These biographical details are taken from Nasīr al-dīn Hāshimī, Kitābkhāna-ye-Nawāb Sālār Jang Marbūm kī Urd̄̄ Qalamī Kitābōn kī Fibrist (Hyderabad: Salar Jung Museum, 1376/1957), pp. 216-17 (Urdu).

190 Mahmūd Bahrī, 'Arūs-e-'Irfān, ms, Salar Jung Library, Hyderabad, Tas. 114.

191 Ibid., f. 21v, 130r-130v.

192 Umar (1993), p. 67. Later better known as the Delhi College, this madrasa, in whose learned atmosphere Fīrōz Jang himself lay buried, continued to be of great importance to the Muslims of Delhi throughout the next century.

193 MN, pp. 131-2, 174.

194 Lest obvious contradictions seem to challenge this, it is well to bear in mind the fact that almost all of the great Chishtī shrines outside of Delhi, whether in the Deccan, Punjab or the 
Tamil south, viewed themselves as transmissions of the mystical authority of the Delhi masters and were often, as with Nizām al-dīn himself, founded by actual immigrants from Delhi.

$195 M N$, pp. 112-76.

196 AS, pp. 62, 82, 90-1.

197 AS, p. 82.

198 Kashkül f. 26v-27r.

199 Maktūbāt, pp. 7-8.

$200 M N$, p. 91.

201 AS pp. 62, 82, 90.

202 C.W. Ernst, 'Royal Policy and Patronage of Sufi Shrines in Mughal Revenue Documents from Khuldabad', in A.R. Kulkarni, M.A. Nayeem and T.R. de Souza (eds), Medieval Deccan History: Commemoration Volume in Honour of P.M. Joshi (Bombay: Popular Prakashan, 1996).

203 Ghulām 'Al̄̄ Āzād Bilgrāmī, Rawzat al-Awliyā (Delhi: Libartī Ārt Prēs, 1416/1996) and Saw.

$204 A S$, pp. 75, 48, 65-9 respectively.

205 See Bhimsen (1972), p. 159 and Sāqi Must'ad Khan (1990), pp. 175-6 and 188.

206 Aurangzeb, Ruka'at-i-Alamgiri, or, Letters of Aurungzebe, trans. J.H. Bilimoria (London: Luzac \& Co., 1908), pp. 163-4.

207 Maktübāt, pp. 45 and 55.

208 On the Mughal and Naqshbandī sense of shared origins, see R. Foltz, 'The Central Asian Naqshbandiyya Connections of the Mughal Emperors', Journal of Islamic Studies, 7, 2 (1996).

$209 M N$, p. 9 and pp. 47-50.

$210 M N$, p. 84 and $A S$, pp. 53, 89, 117.

$211 M N$, p. 117.

$212 A S$, p. 60.

213 AS, p. 81.

214 For example, $M N$, pp. 52, 84, 121.

215 M. Hamidullah, 'Literary Treasures of Aurangabad', Islamic Culture, 16 (1942).

$216 M N$, pp. 67 and 118.

217 MN, p. 107.

$218 M N$, pp. 73-4.

$219 M N$, pp. 81, 102, 143.

220 This text survives in its later expansion as the Urdu Kitāb-e-a'rās (Makhzan-e-a'rās) of Muhammad Najīb Qādirī Nagawrī.

221 Umar (1993), p. 133.

222 AS, pp. 55-6.

223 Kashkül and Kalimullah Jahanabadi, Tasnim ul Toubeed, or Unity of God (Madras: Hue \& Co., 1909).

224 Hadi (1995), pp. 429-30.

\section{THE POETRY AND POLITICS OF SAINTHOOD IN A MUGHAL SUCCESSOR STATE}

1 Saw, f. 371. The description is of the death anniversary ('urs) of Shāh Nūr during the second half of the eighteenth century.

2 See C.W. Ernst, 'India as a Sacred Islamic Land', in D.S. Lopez (ed.), Religions of India in Practice (Princeton, NJ: University of Princeton Press, 1995).

3 On these mathnawīs, see A. Suvorova, Masnavi: A Study of Urdu Romance (Karachi: Oxford University Press, 2000), pp.1-43.

4 See S. Bayly, Saints, Goddesses and Kings: Muslims and Christians in South Indian Society, 1700-1900 (Cambridge: Cambridge University Press, 1989) on similar shrine patronage in the Mughal successor state of Arkat (Arcot). 
5 Such urban and regional rivalry could lead saintly burials to take interesting forms, although without resorting to European customs of saintly exhumation and body-snatching. While Awrangabad's response was to develop shrines of its own, competition between royal capital and provincial hometown for the possession of the remains of the founder of the North African Rahmāniyya order, Sīdī 'Abd al-Rahmān, led in nineteenth-century Algeria to the construction of two rival tombs for the saint and a subsequent tradition of the miraculous duplication of the saint's cadaver. See J. Clancy-Smith, 'The Man With Two Tombs: Muhammad Ibn 'Abd Al-Rahman, Founder of the Algerian Rahmaniyya, c.1715-1798', in G.M. Smith and C.W. Ernst (eds), Manifestations of Sainthood in Islam (Istanbul: Isis Press, 1993), pp. 167-8.

6 Cf. R.M. Eaton, The Rise of Islam and the Bengal Frontier, 1204-1760 (Berkeley, CA: University of California Press, 1993) and B.B. Lawrence, 'Islam in India: The Function of Institutional Sufism in the Islamization of Rajasthan, Gujarat and Kashmir', Contributions to Asian Studies, 17 (1982).

7 'amira, p. 38.

8 See respectively R.M. Eaton, 'The Court and the Dargāh in the Seventeenth Century Deccan', Indian Economic and Social History Review, 10 (1973) and Eaton (1993).

9 See S.S. Blair, 'Sufi Saints and Shrine Architecture in the Early Fourteenth Century', Muqarnas, 7 (1990), L. Fernandes, The Evolution of a Sufi Institution in Mamluk Egypt: The Khanqah (Berlin: Klaus Schwarz, 1988) and L. Golembek, 'The Cult of Saints and Shrine Architecture in the Fourteenth Century', in D.K. Kouymjian (ed.), Near Eastern Numismatics, Iconography, Epigraphy and History: Studies in Honour of George C. Miles (Beirut: American University of Beirut, 1974).

$10 M N$, pp. 34-5.

11 Fernandes (1988).

12 J. Gross, 'The Economic Status of a Timurid Sufi Shaykh: A Matter of Conflict or Perception?', Iranian Studies, 21 (1988).

13 J.R.I. Cole, Roots of North Indian Sh'̈'ism in Iran and Iraq: Religion and State in Awadh, 1722-1859 (Berkeley, CA: University of California Press, 1988).

14 On such patterns of inheritance among the early Chishtīs, see S. Digby, 'Tabarrukat and Succession among the Great Chishti Shaykhs', in R.E. Frykenberg (ed.), Delhi Through the Ages: Essays in Urban History, Culture and Society (Delhi: Oxford University Press, 1986).

15 MN, p. 71.

$16 M N$, pp. 60 and 37 respectively.

17 Tadh, vol. 2, pp. 567-9.

18 NA, pp. 16-19, Âftäb, pp. 15-16, Tadh, pp. 1107-13.

$19 M U$, pp. 476-7.

20 This is also reported in Tadh, p. 1109.

21 Nur, p. 9. Muhammad Ikrām was also a follower of Shāh Nūr himself. He is mentioned as $q \bar{a} \bar{z} \bar{\imath}$ of Awrangabad in the Ma'àthir-e-'Ālamgīiñ. See Saqi Must'ad Khan (1990), pp. 146, 239, 241. The career of Muhammad Ikrām's sons, who served in North India with the Bārhā Sayyids before entering the service of Nizām al-Mulk, is also described in connection with Malkāpūrîs account of Shāh Nūr (Tadh, pp. 1105-6).

22 In recent years, many of the original buildings have been demolished to make way for a new mosque, though the small retreat (bujra) of Shāh Nūr remains.

$23 M U$, p. 477.

24 Tadh, p. 1112.

25 Nur, p. 19.

26 Saw, f. 371.

27 Tadh, p. 1113.

28 Saw, f. 371-38r.

29 NA, pp. 15, 10-11, 9-10. 
$30 N A$, p. 2. This composite imagery is far from unusual in India and was mirrored in that of a saint from another 'frontier' region in the rise of the pre-eminent saint of Bengal, Satyā Pīr.

31 For example, Makhzan, p. 59, Saw f. 37r.

32 G. Asanova and M. Dow, 'The Sarrāfān Baths in Bukhara', Iran, 39 (2001) and J. Gonnella, Islamische Heiligenverehrung im urbanen Kontext am Beispiel von Aleppo (Syrien) (Berlin: Klaus Schwarz, 1995), pp. 136-7.

33 Trimmingham The Sufi Orders in Islam (Oxford: Clarendon Press, 1971), pp. 34-5.

34 M. Kiyānī, Tārīkh-e-khānaqāh dar İrān (Tehran: Tahūrī, 1369/1990), pp. 132-3.

35 K.G. Schwerin Indirekte Herrschaft and Reformpolitik in indischen Fürstenstaat-Hyderabad 1853-1911 (Weisbaden: Steiner, 1980) p. 55. The current sajjāda nashīn of Shāh Nūr is the source for the tombs' identification, while Tadh (p. 1106) confirms the close association of Qūlī Khān Sālār Jang with one of Shāh Nūr's eighteenth-century followers.

36 G.S. Sardesai (ed.), Selections from the Peshwa Daftar, vol. 25 (Bombay: Government Central Press, 1932), documents 116-19 (Marathi) (cited in Ramzan 1982).

37 Shafīq Awrangābādī, Gul-e-Ra'nāa, ms, Salar Jung Library, Hyderabad, Tad. 38, f. 209v.

38 The poem is quoted in M. Raf'at, Panchakki-ye-Awrangābād (Haydarabad: Matba'a-yeIbrāhīmiyya, n.d.), p. 25.

39 On Shāh Mahmūd's successors, see Raf'at (n.d.), pp. 24-26. On an early twentiethcentury shajaranama his name is also given as Muhammad Sayyid.

40 Saw, f. 331-34r.

41 Saw, f. 33r, 34r.

42 'A mira, p. 455.

43 Saw, f. 34 r.

44 Ramzan (1982), Appendix, document 25.

45 'Āmira, p. 454.

46 Ramzan (1982), Appendix, document 10.

47 Ramzan (1982), Appendix, documents 13, 15, 53.

48 Ramzan (1982), p. 298 and Appendix, documents 90, 91, 92.

49 See Ernst (1996), S. Gordon, 'Maratha Patronage of Muslim Institutions in Burhanpur and Khandesh', in Gilmartin and (eds), Lawrence Beyond Turk and Hindu: Retbinking Religious Identities in Islamicate South Asia (Gainsville, FL: University of Florida Press, 2000) and N.S. Green 'Auspicious Foundations: The Patronage of Sufi Institutions in the Late Mughal and Early Asaf Jah Deccan', South Asian Studies, 20 (2004).

50 Panchakkī Collection, document $\mathrm{K}$.

51 C.A. Storey, Persian Literature: A Bio-bibliographical Survey, 2 vols (London: Luzac \& Co, 1927-71), p. 856.

52 Shafīq Awrangābādī, Gul-e-Ra'nā, ms, Salar Jung Library, Hyderabad, Tad. 38, f. $374 \mathrm{r}-377 \mathrm{v}$.

53 Ibid., f. 163r-65v.

54 Ramzan (1982), p. 263.

55 Saw, f. 331-34r.

56 Saw, f. 33r-331.

57 Saw, f. 33 r.

58 S. Faroqhi, 'Agricultural Crisis and the Art of Flute-Playing: The Worldly Affairs of the Mevlevi Dervishes', Turcica, 20 (1988), p. 62.

59 Cf. the prominent role played in the nineteenth century by the sajjäda nashin of the Chishtī shrine at Tawnsa in Punjab in the development of local trade and industry, helping transform Tawnsa from village to town in a remarkably short time. This is described in D.C. Phillot, 'Note on the Shrine at Taunsa', Journal of the Asiatic Society of Bengal, 4, 1 (1908).

60 Saw, f. 331.

61 Saw, f. 34l-5l. 
62 'Imād al-Mulk Ghāzī al-dīn Khān, Manāqib-e-Fakbriyya, ms, Salar Jung Library, Hyderabad, T-S. 31, f. 7v.

63 Saw, f. 34l-34r.

64 T.W. Beale The Oriental Biographical Dictionary (Calcutta: Asiatic Society of Bengal, 1881), p. 96.

65 K.A. Nizāmī Tārīkh-e-Mashä’’kh-e-Chisht (Delhi: Idarah-e-Adabiyyal-e-Dilli, 1980-5) (Urdu), pp. 530-60.

66 The court diary is quoted in P. Spear, Twilight of the Mughals: Studies in Late Mughal Delhi (Cambridge: Cambridge University Press, 1951), p. 78.

67 On various aspects of Awrangabad's literary scene during this period, see $R H$, pp. 50-109.

68 'Abd al-Jabbār Khān Malkāpūrī, Mabbūb al-Zamān: Tadbkira-ye-Shu'arā-ye-Dakan (henceforth Tadh 2), (Hyderabad: Hasan Press, 1327/1909), p. 524.

69 Tadh 2, p. 392.

70 Tadh 2, p. 562.

71 See S. Bayly Saints, Goddesses and Kings: Muslims and Christians in South Indian Society, 1700-1900 (Cambridge: Cambridge University Press, 1989) and J.J.L. Gommans, The Rise of the Indo-Afghan Empire, c. 1710-1780 (Delhi: Oxford University Press, 1999).

72 P.S.M. Rao, Eighteenth Century Deccan (Bombay: Popular Prakashan, 1963), pp. 81, 85-6, 95, 112-13, 120-1.

73 Nizām al-Mulk Āsaf Jāh, Wasiyatnāma-ye-Āsaf Jāh, ms, Salar Jung Library, Hyderabad, Hist. 454. The reference to the arbāb-e-allāb is found on $\mathrm{f}$. 3v. Although supposedly dictated by Nizām al-Mulk himself from his deathbed in 1161/1748, there is some doubt about the authenticity of this document.

74 Muhammad Haydar, Anwār-e-Tajalliyāt, ms, Salar Jung Library, Hyderabad, Tas. 18. The dedication to Nizām al-Mulk is on f. $2 \mathrm{v}$.

75 Ibid., f. 10v.

76 Ibid., f. $11 \mathrm{v}-12 \mathrm{r}$.

77 Ibid., f. $12 \mathrm{v}-13 \mathrm{r}, 15 \mathrm{v}$.

78 Ibid., f. $18 \mathrm{r}$.

79 Abū'l Hasan ibn Sayyid Muhyī al-dīn Bukhārī, Risāla-ye-'Aynak-e-Būqalmūn, ms, Salar Jung Library, Hyderabad, Tas. 261. References to Farīd al-dīn Shakar Ganj and Gēsū Darāz are found on f. 9v and f. $24 \mathrm{r}$ respectively.

80 Ibid., f. $11 \mathrm{v}-17 \mathrm{v}$.

81 Ibid., f. $24 \mathrm{v}-25 \mathrm{v}$.

82 Tadh 2, pp. 607-18, Chittick (1992).

83 Subhat (1976-80), 1, p. 288. I am grateful to Carl Ernst for this reference.

84 Tadh, vol. 2, pp. 724 and 903.

85 Shafīq Awrangābādī, Gul-e-Ra'nā, ms, Salar Jung Library, Hyderabad, Tad. 38, f. 209v-210r and Tadh, vol. 2, pp. 562-3.

86 Rao (1963), pp. 62, 66-7.

87 Cf. M.E. Subtelny, 'The Cult of 'Abdullāh Ansārī under the Timurids', in C. Bürgel and A. Giese (eds), God is Beautiful and He Loves Beauty (Festschrift for Annemarie Schimmel) (Bern: Peter Lang, 1994) and C.S. Taylor, In the Vieinity of the Righteous: Ziyara and the Veneration of Muslim saints in Late Medieval Egypt (Leiden: E.J. Brill, 1999). The creation of urban networks of patron saints and shrines seems also to have been one of the basic means of the settling, Islamization and 'Mughalization' of Bengal. See Eaton (1993).

88 Cf. S. Bayly (1989) and D. DeWeese, 'Sacred History for a Central Asian Town. Saints, Shrines and Legends of Origin in Histories of Sayrām, 18th to 19th Centuries', Révue des Mondes Musulmans et de la Méditerranée, 89-90 (2000).

89 Shafīq Awrangābādī, Untitled ('A Description of the City of Hyderabad and Aurangabad'), ms, British Library, Add. 26, 263.

90 Tadh, vol. 2, pp. 576-7. 
91 Tadh, vol. 2, p. 905.

92 See M. Hermansen, 'Religious Literature and the Inscription of Identity: The Sufi Tazkira Tradition in Muslim South Asia', Muslim World, 87, 3-4 (1997) and J.A. Mojaddedi, The Biographical Tradition in Sufism: The Tabaqat Genre from al-Sulami to Jami (London: Curzon, 2001).

93 See $A^{\prime}$ rass and Ernst (1993). The genealogy of such pilgrimage manuals as an elite literary product reached back to Arabian models from earlier centuries. However, as with similar ritual forms, the actual practice involved - here, shrine pilgrimage - cut across barriers of class.

$94 N A$, p. 15.

95 Rao (1963), pp. 220-21, M. Siddiqi, art. 'Āzād Belgrāmī', in Encyclopaedia Iranica (n.d.) and Storey (1927-71), pp. 855-66. On other historical writers of the period, see Z. Malik, 'Social Origins of the Late Eighteenth Century Indo-Persian Historiographers: Perspectives and Responses' in N. Ahmad and I.H. Siddiqui (eds), Islamic Heritage in South Asian Subcontinent, vol. 1 (Jaipur: Publication Scheme, 1998).

96 'Āmira, pp. 35-8, 74-6.

97 'Āmira, pp. 39-49.

98 'Āmira, p. 35.

99 'Āmira, p. 38.

100 Storey (1927-71), p. 856.

101 T.W. Haig, Historic Landmarks of the Deccan (Allahabad: n.p., 1907), p. 58.

$102 M K$, pp. 171-5.

103 MN, p. 112.

104 Tadh 2, p. 837.

105 Despite this, Bilgrāmī’s account has been shown by S. Digby 'Before the Bābās came to India: A Reconstruction of the Earlier Lives of Bābā Sa'ìd and Bābā Muhammad Musafir in "Wilāyat"', Iran, 36 (1998) to possess important sections of historical authenticity shedding light on lacunae in the Malfüzāt-e-Naqshbandiyya.

106 Digby (1998), pp. 144-5.

$107 R A$, pp. 111-12.

$108 M U$, pp. 476-7.

109 MN, p. 91.

$110 N A$, pp. 1, 5.

$111 N A$, p. 1 and $M K$, p. 172.

$112 N A$, p. 2.

113 NA, p. 2.

114 NA, pp. 11-12. Cf. the appearance of Khizr to Shāh Palangpōsh in MN, p. 4.

$115 N A$, pp. 2, 5-6.

116 NA, p. 12.

117 NA, p. 5.

$118 N A$, pp. 6-8.

$119 N A$, pp. 2, 13-15 and 15 respectively.

$120 N A$, pp. 9-10 and 3-4 and 16-19 respectively.

121 Saw, f. 10l-11r.

122 Saw, f. $19 \mathrm{r}-191$.

123 Saw, f. 37r-38r.

\section{THE SUFIS IN THE SHADOW OF A NEW EMPIRE}

1 Saw, f. 35r. Ranginn, 'colourful', also suggestive of the metaphorical and transient.

2 On this period, see K. Sajun Lal, Studies in Deccan History (Madras: Business Week Press, 1951).

3 W. Dalrymple, The White Mughals: Love and Betrayal in Eighteenth-Century India (London: HarperCollins, 2002). 
4 J. Grant, 'Political Survey of the Deccan' (1782), British Library (OIOC), Hastings Collection, Add. Mss. 29, 209, 411r.

5 Grant (1782), 441v-442r.

6 Grant (1782), 439r-439v.

7 B.N. Ramusack, The Indian Princes and Their States (New Cambridge History of India, III 6) (Cambridge: Cambridge University Press, 2004).

8 On this period, see S. Chander, 'From a Pre-Colonial Order to a Princely State: Hyderabad in Transition c.1748-1865', (Unpubl. Phd thesis, Cambridge University, 1987) and P. Wood, 'Vassal State in the Shadow of Empire: Palmer's Hyderabad, 1799-1867' (unpubl. PhD thesis, University of Wisconsin-Madison, 1981).

9 J.B. Seely, The Wonders of Ellora (London: G. and W.B. Whittaker, 1824), pp. 333-421.

10 G. Sydenham (1811), 'Gulbarga', British Library (OIOC), Mackenzie Collection: General, vol. XLIII.

11 Nehrī Collection, document $4 \mathrm{r}$.

12 Jaffur Shureef, Qanoon-e-Islam, or the Customs of the Mussulmans of India, trans. G.A. Herklots (Delhi: Asian Educational Services, 1991 (1863)), pp. 155-7 and 175.

13 See J.M.S. Baljon, 'Shah Waliullah and the Dargah', in C.W. Troll (ed.), Muslim Shrines in India: Their Character, History and Significance (Delhi: Oxford University Press, 1989).

14 Seely (1824), p. 371.

15 Taylor (1837), n.p. 'Of course', Taylor added dryly, 'no one presumes to interrupt him [the tiger] in his meritorious employment.'

16 J.R.I Cole, Roots of North Indian Shi'ism in Iran and Iraq: Religion and State in Awadh, 1722-1859 (Berkeley, CA: University of California Press, 1988), pp. 145-59.

17 Mubārizal-din Raf'at, Panchakkī-ye-Awrangābād (Haydarabad: Matba'a-ye-Ibrāhīmiyya, n.d.), p. 25.

18 Ramzan (1982), Appendix, documents 12, 90, 91, 92.

19 Document Panchakkī L (copy in author's possession).

20 On the rise of the Mujaddidiyya in India, see A. Buehler, Sufi Heirs of the Prophet: The Indian Naqshbandi Brotherhood and the Rise of the Mediating Sufi Shaykh (Columbia, NC: University of South Carolina Press, 1998).

21 Anon., 'The Durgahs and Mahomedan Saints of Hindostan', Asiatic Journal, 19 (1836) and Seely (1824).

22 K. Rizvi, "Its Mortar Mixed with the Sweetness of Life": Architecture and Ceremonial at the Shrine of Safī al-dīn Ishāq Ardabīlī During the Reign of Shāh Tahmāsb I', Muslim World, 90, 3 and 4 (2000), p. 345.

23 Seely (1824), pp. 380-91.

24 Appropriately, Sir Richard Burton used the same quotation from Milton a few decades later, in the second appendix of his Pilgrimage to al-Madinah and Meccah, when describing the interior of the Ka'ba at Mecca.

25 M. Hamidullah 'Literary Treasures of Aurangabad (Two Important Collections of Rare MSS)', Islamic Culture, 16 (1942).

$26 \bar{A} t h \bar{a} r$, bk. 4, pp. 34-5.

27 P. Spear, Twilight of the Mughals: Studies in Late Mughal Delhi (Cambridge: Cambridge University Press, 1957), pp. 78-9.

$28 \bar{A} t h \bar{a} r$, bk. 4, pp. 34-5.

29 T.W. Beale, The Oriental Biographical Dictionary (Calcutta: Asiatic Society of Bengal, 1881), p. 140.

30 Altāf Husayn Hālī, Yādgār-e-Ghālib (Delhi: Maktaba Jāma'a'l-Mutīd, 1971), vol. 1 (Hissa Urdū), p. 42.

31 R. Russell and K. Islam (ed. \& trans.), Ghalib 1797-1869, vol. 1, Life and Letters (London: George Allen and Unwin, 1969), pp. 71, 116.

32 Russell and Islam (1969), p. 73. 
33 D.C. Phillot, 'Note on the Shrine at Taunsa', Journal of the Asiatic Society of Bengal, 4, 1 (1908).

34 Ghulām 'Alī Qādirī, Mishkat al-nubuwwat, trans. Abū'l Fazl Sayyid Mahmūd Qādirī (Haydarabad: A‘jāz Printing Press, 1982), vol. 7 (mishkat 31), pp. 113-15 (Urdu).

35 'Imād al-Mulk Ghāzī al-dīn Khān Fīrōz Jang III, Manāqib-e-Fakbriyya, ms, Salar Jung Library, Hyderabad, T-S. 31, f. 4r-7r (Persian).

36 Ibid., f. 5v.

37 Ibid., f. 7v, 10r-11v.

38 'Imād al-Mulk Ghāzī al-dīn Khān, Fakbriyyat al-Nizām (henceforth Fakbriyyat) (ms, shrine library of Nizām al-dīn Awrangābādī, Awrangabad), pp. 92-3.

39 Ibid., pp. 136-8.

40 Mansārām described the resident faqūrs at the shrine of Qādir Awliyā complaining that there was not enough money for celebrating the saint's death anniversary or for feeding the poor, and that as a result many of the faqìrs had become addicted to smoking the water-pipe. Nizām al-Mulk subsequently issued a command to appoint one Sayyid Muhammad Mugnī to manage the shrine, but also scolded the faqiers for appreciating the glow of the tobacco pipe more than the inner fire of devotion. See translation in P.S.M. Rao, Eighteenth Century Deccan (Bombay: Popular Prakashan, 1963), p. 81.

41 A comparable mode of tadhkira analysis is found in C.W. Ernst and B.B. Lawrence, Sufi Martyrs of Love: The Chishti Order in South Asia and Beyond (London: Palgrave Macmillan, 2003), pp. 47-64.

42 Gul Muhammad Ahmadpūrī, Takmila-ye-Siyar al-Awliyā (henceforth Takmila) (ms, K.A. Nizami Collection), f. 83r, 881, 89r.

43 Takmila, f. 881-901.

44 Takmila, f. 841.

45 Àthār, 4, pp. 30-3.

46 Cf. Nizāmī (1980-5), pp. 427-59.

\section{SAINTS, REBELS AND REVIVALISTS}

1 Saw, f. 33r. The description is of the shrine of Shāh Musāfir and Shāh Palangpōsh.

2 S. Regani, Nizam-British Relations, 1724-1857 (Hyderabad: Booklovers Private Ltd, 1963), pp. 214-36. On this period, see also K.G. Schwerin, Indirekte Herrschaft und Reformpolitik im indischen Fürstenstaat Hyderabad 1853-1911 (Wiesbaden: Steiner, 1980) and Y. Vaikuntham, 'Oriental Culture and the Raj (A Study of Hyderabad between 1858-1911)', Proceedings of the Indian Historical Congress, 51st Session (Calcutta University) (1990).

3 S.H. Bilgrami and C. Willmott, Historical and Descriptive Sketch of His Highness the Nizam's Dominions, 2 vols (Bombay: Times of India Steam Press, 1883-84), pp. 331-2.

4 Bilgrami and Willmott (1883-84), p. 614.

5 Anon., The Freedom Struggle in Hyderabad, vol. 2 (Hyderabad: Hyderabad State Committee, 1956), pp. 24-43 and Bilgrami and Willmott (1883), pp. 334-41.

6 R. Jayaram, Administrative System under the Nizams, 1853-1935 (Bangalore: Ultra Publications, 1998), pp. 130-5.

7 Jayaram (1998), pp. 133-4.

8 See P.N. Furbank, E.M. Forster: A Life (Oxford: Oxford University Press, 1979), pp. 202, $252-3$.

9 However, between 1872 and 1874 its chaplain was a Parsi convert from Ahmadnagar, Rattanji Nowrozji (d. 1910). I am grateful to Robert Johnson, James Robert Natkar and Rev. John Shrisunder for showing me the parish records and providing other information on the history of Awrangabad's colonial churches.

10 P.V. Kate, Marathwada under the Nizams, 1724-1948 (Delhi: Mittal, 1978), pp. 244-6. 
11 W.W. Hunter et al., Imperial Gazetteer of India (Oxford: Clarendon Press, 1908-31), vol. 6, p. 148.

12 Awrangabad Urdu Mission Annual Report (1913). Copy filed in Lane-Smith (1901-38), Z2.

13 On Sufi and wider Muslim religious life in North India during this period, see F.A. Nizami, 'Madrasahs, Scholars and Saints: Muslim Response to the British Presence in Delhi and the Upper Doab, 1803-1857' (unpubl. DPhil Thesis, University of Oxford, 1983).

14 See Mīrzā Ghālib, Khutūt-e-Ghālib, Ghulām Rasūl Mehr (ed.) (Lahore: Kitāb Manzil, n.d.), p. 71.

15 Ibid., p. 422. Author's translation.

16 I have been unable to identify this figure with certainty. It seems possible that this was Mīrān Shāh Muhammad, the son of Bahadur Shah, who was known as a Sufi in the lineage of Fakhr al-dīn. See K.A. Nizāmī, Tārīkh-e-Mashā'ikh-e-Chisht (Delhi: Idāra-yeAdabiyyat-e-Dillī, 1980-5), p. 525.

17 Mīrzā Muhammad Akhtar Dihlawī, Tadbkira-ye-Awliyā-ye-Hind (Delhi: Mīwar Prēs, 1906), vol. 2, pp. 133-5. The account is found in the notice on Mawlānā Fakhr al-dīn (pp. 126-37).

18 Ibid., p. 134.

19 See M. Hasan, 'Bahadur Shah II, His Relations with the British and the Mutiny', Islamic Culture, 33 (1959), pp. 110-11. The story was recorded by the contemporary Delhi historian, Zakā Allāh.

20 Mīrzā Muhammad Akhtar Dihlawī (1906), p. 135.

21 This Nizām al-dīn later returned to Delhi and was eventually buried beside his father Nasīr al-dīn and his ancestor Fakhr al-dīn at the shrine of Qutb al-dīn Bakhtiyār Kākī at Mihrawli on the outskirts of Delhi. See M. Umar, Islam in Northern India During the Eighteenth Century (Delhi: Manoharlal Munshiram, 1993), pp. 138-9.

22 See W. Fusfeld, 'The Boundaries of Islam and Infidelity', in K. Ewing (ed.), Shari' at and A mbiguity in South Asian Islam (Berkeley, CA: University of California Press, 1988), pp. 206-7.

23 This account draws on the family history of Mīrzā 'Abd Allāh's descendants in Haydarabad, as reported in The Hindu, 12 September 2002.

24 The dates of the deaths of these figures are all inscribed on their tombs in Nizām al-dīn's shrine.

25 This farmān is referred to in a later legal document from 1967 relating to claims made after Qaysar Miyān's death (Regular Civil Suit No. 16 of 1966, Aurangabad), a copy of which is in the author's possession.

26 D.C. Phillott, 'Note on the Shrine at Taunsa', Journal of the Asiatic Society of Bengal, 4, 1 (1908).

27 Phillott (1908), p. 28.

28 Tadh, pp. 1097-9.

29 Hab̄̄b 'Alī Shāh, Yār Khān Bahādur, Hab̄̄b al-tālibìn, ms, Salar Jung Library, Hyderabad, Tas. 50, f. 57r, 107-108r.

30 Habīb 'Alī Shāh, Yār Khān Bahādur, Habīb al-Barāzikh, ms, Salar Jung Library, Hyderabad, Tas. 49, pp. 5, 8-9, 65.

31 On Hāfiz 'Alī Shāh, see K.A. Nizāmī, Tārīkh-e-Mashā'ikh-e-Chisht (Delhi: Idāraye-Adabiyyat-e-Dillī, 1980-5), pp. 667-84 (Urdu).

32 Banē Miyān Collection, document A (copy in author's possession).

33 S.V.R. Nasr, Mawdudi and the Making of Islamic Revivalism (Oxford: Oxford University Press, 1996), pp. 9-12. Investigations have failed to further clarify the identity of Muhyi al-dīn. It is possible that he was the same Chishtī Sufi of this name who authored the Urdu hagiography Afzal al-karāmāt on the life of Afzal Shāh Biyābānī (d. 1273/1856). Though mainly a resident of Haydarabad, this Muhyī al-dīn visited Awrangabad on numerous occasions during the period in question. He died in Haydarabad in 1943. (I am grateful to Syed Shujathullah of Warangal for information on this figure.)

$34 \bar{A} f t \bar{a} b$, pp. 16-17. 
$35 \bar{A} f t a \bar{a}$, pp. $16-17$.

36 N.S. Green, 'Mystical Missionaries in Hyderabad State: Mu'īn Allāh Shāh and his Sufi Reform Movement', Indian Economic and Social History Review, 41, 2 (2005).

$37 \bar{A} f t a \bar{b}$, pp. 16-17 and 21-6.

38 Interview with Baba Pir, grandson of Shams al-dīn, Awrangabad, 3.9.2000.

$39 \bar{A} f t \bar{a} b$, p. 17.

40 See Zahūr's introduction to his Urdu translation of 'Urūj. NA (p. i).

41 Ibid. On the claim to Banē Miyān’s British following, see Muhammad Ismā‘̄il Shāh Qādirī, A'zam al-Karāmāt (henceforth $A K$ ) (Awrangabad: Mu'in Press, c.1340/1921), p. 12.

42 M. Warren, Unravelling the Enigma: Shirdi Sai Baba in the Light of Sufism (Delhi: Sterling Publishers, 1999), p. 118.

43 Tadh, p. 1102. Older devotees remember the presence of resident dervishes there until the 1940s.

44 Nehrī Collection, document 3 (copy in author's possession).

45 The date is given in the Faslī calendar as 1338. See $\bar{A} f t \bar{a} b$, p. 17.

$46 \bar{A} f t \bar{a} b$, pp. 16-17.

47 Mubāriz al-dīn Raf'at, Panchakkī-ye-Awrangāāād (Haydarabad: Matba'a-ye-Ibrāhīmiyya, n.d., c.1957), p. 25.

48 Cf. R.M. Eaton, 'The Court and the Dargāh in the Seventeenth Century Deccan', Indian Economic and Social History Review, 10 (1973).

49 AK, pp. 70-1.

50 Raf'at (n.d.), p. 25. Mubāriz al-dīn Raf'at seems to have known Ghulām Mahmūd personally and, writing four decades after the latter's death, recounted the respect with which his memory was still greeted.

51 In the 1990s many older residents of Awrangabad could remember dervishes resident at the shrine earlier in the century.

52 M. Hamidullah, 'Literary Treasures of Aurangabad (Two Important Collections of Rare MSS)', Islamic Culture, 16 (1942).

53 D.G. Qureshi, Tourism Potential in Aurangabad (Delhi: Bharatiya Kala Prakashan), pp. 60-1.

54 M. Gill and J. Fergusson, One Hundred Stereoscopic Illustrations of Architecture and Natural History in Western India (London: Cundall, Downes and Company, 1864), p. 73.

55 Furbank (1979), p. 252.

56 Two of Raja Deen Dayal's photographs of the shrine are in the photographic collections of the India Office Library (OIOC, photo 430/6/55 \& 430/6/56).

57 M.A. Jabbar, Glimpses of Panchakee (Bombay: Bhal Malji, n.d.), pp. 8-9 and Raf at (n.d.), p. 25.

58 This sequence of events is described in Raf at (n.d.), pp. 25-6.

59 This fact is mentioned in 'Alī al-dīn Ahmad's brief Urdu foreword to the Persian printed edition of the Malfüzāt-e-Naqsbbandiyya.

60 S. Ramzan, 'Medieval Aurangabad: A Cultural Study', unpubl. PhD dissertation, Marathwada University (1982), p. 276.

61 For Ghālib’s letters to Sayyāh, see Mīrzā Ghālib (n.d.), pp. 428-51.

62 Anonymous, The Freedom Struggle in Hyderabad, 4 vols (Hyderabad: Hyderabad State Committee, 1956), vol. 4, pp. 278-84.

63 K. Leonard, 'Hyderabad: The Mulki-Non-Mulki Conflict', in R. Jeffrey (ed.), People, Princes and Paramount Power: Society and Politics in the Indian Princely States (Delhi: Oxford University Press, 1978), p. 88.

64 Amjad Husayn, Tārīkh-e-Dakan mulaqab ba Riyāz al-rabmān al-ma'rüf ba Tārīkh-eAmjadiyya (Haydarabad: Matba'a-ye-Khūrshīdiyya, 1293/1876) and Ghulām Imām Khān, Tārìkh-e-Khūrshīd Jāhī wa Tārīkh-e-Khujista Bunyād (Awrangabad: n.p, c.1318/1900).

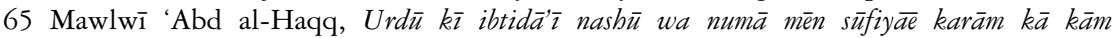
(Awrangabad: Matba'a-ye Anjoman-e-Taraqī-ye-Urdū, 1933).

66 S. Ramar Char, 'Education in Hyderabad', Modern Review 66 (1939). 
67 Sayyid Imām al-dīn Naqwī Hanafī Gulshanābādī, Tadhkira-ye-buzurgān-e-Dakan Barakāt al-awliya $\bar{a}$ (henceforth Barakāt) (n.p., 1321/1903-4), pp. 136-7.

68 See, for example, Sayyid Abū'l Hasan 'Alī Nadwīi, Tärīkh-e-Da'wat wa 'Azīmat, vol. 3 (Lucknow: Lucknow Publishing House, 1398/1978) (Urdu).

69 Barakāt, p. 128.

70 'Abd al-Jabbār Khān Malkāpūrī, Mabbūb al-watan: Tadhkira-ye-salātīn-e-dakan, 3 vols (Haydarabad: Matba'a-ye-Fakhr-e-Nizāmī, n.d.) and Mabbūb al-zamān: Tadhkira-yeshu'arā-ye-dakan, 2 vols (Haydarabad: Matba'a-ye-Fakhr-e-Nizāmīi, 1329/1911).

71 Malkāpūrī also clearly stated this (Tadh, p. 1112).

72 Tadh, pp. 1101-13.

73 Tadh, pp. 1102, 1108, 1111.

74 Tadh, pp. 1109-12.

75 T.W. Beale, The Oriental Biographical Dictionary (Calcutta: Asiatic Society of Bengal, 1881), p. 248.

76 Ghulām Sarwar Lāhawrī, Khazīnat al-Asfiy à (henceforth Khaz), 2 vols (Lucknow: Matba'a Munshī Nawal Kishawr, 1312/1894), vol. 1, pp. 495-7.

77 Khaz, pp. 496-7.

$78 \mathrm{~J}$. Gonnella, Islamische Heiligenverehrung in urbanen Kontext am Beispiel von Aleppo (Syrien) (Berlin: Klaus Schwarz, 1995).

79 Barakāt, p. 144, Tadh, p. 1093. On the genealogy of the Āsaf Jāhs, see Y. Husain, The First Nizam: The Life and Times of Nizāmu'l-Mulk Āsaf Jāh I (London: Asia Publishing, 1963), pp.1-66.

80 Barakāt, p. 144. There was in fact an historical dimension to this, for Kalīm Allāh's stately bequest was made in a letter preserved in his letters. See Maktūbāt, p. 26.

81 Barakāt, p. 144, Tadh, pp. 1093-100.

82 For example, Tadh (p. 1094) reworks the story of the drought given in AS (p. 48).

83 AS, pp. 97-8.

84 Tadh, pp. 1094-6.

85 BK, p. 15, Tadh, pp. 1098-9.

86 Tadh, p. 1099. Cf. Eaton (1973) on the earlier bureaucratizing of shrines elsewhere in the Deccan.

87 Tadh, pp. 1097-8. Around the same time, in 1915 Muhammad Iqbāl included an allusion to the legend of a similar battlefield meeting between Shah Jahan and the North Indian Sufi Miyān Mīr Walī (d. 1045/1635) in his Persian poem Asrār-e-khūd̄̄ (lines 1340-70).

88 Ernst (1992), p. 92. I have been unable to trace a copy of Kishan Parshād's hagiographical work.

89 Rawnaq 'Alī, Rawzat al-aqtāb (Awrangabad: Sawira Offset, 1420/2000), henceforth Aqtāb, pp. 22-3.

90 Aqtāb, pp. 34-6.

91 Aqtāb, pp. 40-1.

92 Aqtāb, pp. 132-4.

93 Aqtāb, pp. 182-9.

\section{THE AWRANGABAD SAINTS IN THE NEW INDIA}

1 Saw, f. 35r. The description is of the now forgotten Sufi of Mughal Awrangabad, Sayyid Abū'l Qāsim.

2 W. Cantwell Smith, 'Hyderabad: Muslim Tragedy', Middle East Journal, 4 (1950) and O. Khalidi (ed.), Hyderabad: After the Fall (Wichita: Hyderabad Historical Society, 1988).

3 Some alleged claims run as high as 200,000 dead. See Khalidi (1988), p. 99.

4 See Pandit Sundarlal and Qazi Muhammad Abdulghaffar, 'A Report on the Post-Operation Polo Massacres, Rape, and Destruction or Seizure of Property in Hyderabad State', in Khalidi (1988), pp. 103-11.

5 Ibid., p. 106. 
6 O. Khalidi, 'The Hadhrami Role in the Politics and Society of Colonial India, 1750s-1950s', in U. Freitag and W.G. Clarence-Smith (eds), Hadhrami Traders, Scholars, and Statesmen in the Indian Ocean, 1750s-1960s (Leiden: Brill, 1997), pp. 80-1. Nonetheless, a Hadrāmī community survived in the Deccan and at the end of the twentieth century continued to form one of several endogamous sub-communities among Awrangabad's Muslims.

7 A.M. Khusro, Economic and Social Effects of Jagirdari Abolition and Land Reforms in Hyderabad (Hyderabad: Osmania University Press, 1958).

8 G.C. Kozlowski, Muslim Endowments and Society in British India (Cambridge: Cambridge University Press, 1985).

9 On the Muslims of Awrangabad during this period, see M.A. Khan, 'Intergenerational Mobility among Muslims in Aurangabad: a South Indian City', Journal of the Institute of Muslim Minority Affairs, 8 (1987) and M.A. Khan, 'Social Change among the Muslims of Awrangabad City', in A.A. Engineer (ed.), Problems of Muslim Women in India (Hyderabad: Orient Longman, 1995).

10 Aftab, p. 17. Written by an influential member of Shāh Nūr's management committee, this document supports the role of the committee itself at the shrine after Shams al-dinn's death and does not make any mention of Shams al-dīn's spiritual heirs.

11 Aftab, pp. 24-5.

12 Aftab, p. 26. This section is also based on interviews with Mohammed Sharafuddin Siddiqui, head of the shrine committee, during 1999 and 2000.

13 On this movement, see U. Sanyal, Devotional Islam and Politics in British India: Abmad Riza khan Barelwi and His Movement, 1870-1920 (Delhi: Oxford University Press, 1996).

$14 \mathrm{He}$ is not to be confused with the contemporary local saint, Muhammad A'zam Khan Banē Miyān (d. 1339/1921).

15 Interviews with Bābā Pīr, son of Banē Miyān, and Mīrzā Ibrāhīm Bēg, disciple of Banē Miyān, September 2000.

16 Saw, f. 37r.

17 Mìrzā Āghā Bēg and Sūfī Muhammad Mazhar Nizāmī Chishtī Qādirī, Awliyā Allāh: Gulshan-e-Hamawī (Awrangabad: Sun Rays Offset Printers, 2003).

18 Much of this information draws on interviews with Ghulām Mahmūd's relative, Rizwana Maghrebi, and older residents of Awrangabad.

$19 \mathrm{Raf}^{\prime}$ at (n.d.).

20 Syed Shah Yousufuddin Magrabi, Awrangabad's Old Water Supply System of Aqueducts (Awrangabad: Syed Shah Yousufuddin Magrabi, 1981). See also Raf'at (n.d.) and Ramzan (1982).

21 M.A. Jabbar, Glimpses of Panchakee (Bombay: Bhal Malji, n.d.), p. 9.

22 Cf. Z. Bauman, 'From Pilgrim to Tourist - Or, a Short History of Identity', in S. Hall (ed.), Questions of Cultural Identity (London: Sage, 1996).

23 The local historian Mubāriz al-dīn Ra'fat (Ra'fat, n.d., p. 22) also discussed the legends of Shāh Musāfir's association with Awrangzeb in his Urdu history of Panchakkī, similarly concluding that had any such connection really existed it would surely have received mention in the Malfüzät-e-Naqshbandiyya.

24 M. Hamidullah 'Literary Treasures of Aurangabad (Two Important Collections of Rare Mss)', Islamic Culture, 16 (1942).

25 A diagram and description of this object appears in Hamidullah (1942), p. 451.

26 This is based on conversations with Syed Yaqub Ali, Qaysar Miyān's last surviving disciple, during 1999 and 2000.

27 Details of this are found in an official letter pertaining to Regular Civil Suit No. 16 (1966), Aurangabad. A copy is in the author's possession.

28 Hazrat Khwāja Kāmgār Khān Husayn̄̄, Majālis-e-Kalīmē wa absan al-shamāàil, trans. Muhȳī al-dīn Ahmad Sidīqī (Awrangābād: Super Offset Printers, 2003).

29 Sayyid Hasan, Hālāt $\bar{u}$ Zindagì-ye-Nizām al-dīn Awliya Awrangābād $\bar{\imath}$ (henceforth Hasan) (Awrangabad: n.p., n.d. (c.1995)) (Urdu). 
30 Wahīda Nasīm, Shāhān-e-bē-tāj (Karachi: Maktaba-ye-Āsafiyya, 1988). A translation of Wahīda's ghazal on the Khuldabad saints appears in Ernst (1992), pp. 246-7.

31 Al-Hāj Muhammad 'Abd al-Hayy, Gulistān-e-Khuldābād (Awrangabad: Sawira Offset Printers, 1422/2001) (Urdu).

32 Ibid., pp. 315-17.

33 Anon. (1836), Seely (1824).

34 Ghulām Imām Khān, Tārīkh-e- Khürshìd Jāhī/Tārīkh-e-Khujista Bunyād (Awrangabad: n.p, n.d.), p. 6.

35 Raf'at (n.d.).

36 Internal evidence in the text suggests an original composition date during the 1950s, with details of recent building activities at the shrine added for a second edition published during the 1980s.

$37 \bar{A} f t \bar{a} b$, pp. 4-5.

$38 \bar{A} f t a \bar{b}$, pp. $7-8$.

$39 \bar{A} f t a \bar{b}$, p. 5.

$40 \bar{A} f t a \bar{b}$, p. 8.

$41 \bar{A} f t a \bar{b}$, pp. 8-10.

$42 \bar{A} f t a \bar{b}$, pp. 18-21. It is in fact fairly common for Urdu pamphlet biographies of the saints to maintain the memory of notables and royalty. In the shrine of Zayn al-dīn Shīrāzì at Khuldabad, biographies of the saint and the adjacently interred Awrangzeb are sold side by side.

$43 \bar{A} f t \bar{a} b$, pp. 17 and 24.

44 Nizāmī (1980-5), pp. 427-59.

45 Hasan, p. 8.

46 Hasan, pp. 15-16 and 2 respectively.

47 Cf. $A S$, pp. 58 and $97-8$ on meetings with yogis and pp. 64, 79-81, 84, 86, 94-6, $113-14,116-18$ on discussions of samás.

48 Hasan, pp. 20-4.

49 Hasan, pp. 23-4.

50 Awrangabad Times Urdu Daily (15 February 2000).

51 This mirroring of narrative and architecture was present at the shrines of many other Muslim saints and Devin DeWeese has described a similar process with regard to the Central Asian shrine of Ahmad Yasawī. See D. DeWeese, "Sacred Places and "Public" Narratives: The Shrine of Ahmed Yasavi in Hagiographical Traditions of the Yasavī Sufī Order, 16th to 17th Centuries', Muslim World, 90, 3 and 4 (2000).

52 Abdul Hamid Khan, interview, 20.2.00.

53 Cf. W. Crooke, Religion and Folklore of Northern India (Oxford: Oxford University Press, 1926), p. 168, S. Digby, 'To Ride a Tiger or a Wall? Strategies of Prestige in Indian Sufi Legend', in W.M. Callewaert and R. Snell (eds), According to Tradition: Hagiographical Writing in India (Wiesbaden: Harrassowitz, 1984) and M. van Bruinessen, 'Haji Bektash, Sultan Sahak, Shah Mina Sahib and Various Avatars of a Running Wall', Turcica, 21-3 (1991), p. 59.

54 According to the sajjäda nashin of the shrine, in earlier times permission was given by state officials for the shrine to be painted in the official yellow colour of the Āsaf Jāh state. However, this would appear to be a classic case of the invention of tradition, since prior to the relatively recent availability of oil-based paints, shrines were invariably only whitewashed. Many other Sufi shrines in India have also adopted bright-coloured paint in recent years, similarly adapting particular colours to elements of local or more widespread saintly traditions; after whitewash green and yellow are in fact the most widespread paints.

55 M.A. Nayeem, The Splendour of Hyderabad: Last Phase of an Oriental Culture (1591-1948 $A D)$ (Bombay: Jaico, 1987).

56 On these legends, see N.S. Green, 'Stories of Saints and Sultans: Re-membering History at the Sufi Shrines of Aurangabad', Modern Asian Studies, 38, 2 (2004). 


\section{BIBLIOGRAPHY}

\section{Primary sources in Islamic languages}

'Abd al-Jabbār Khān Malkāpūrī, Mabbūb al-Zamān: Tadbkira-ye-Shu'arā-ye-Dakan, Hyderabad, Hasan Press, 1327/1909. (Urdu)

'Abd al-Jabbār Khān Malkāpūrī, Mabbūb-e-Dhī'l-minan: Tadbkira-ye-Awliyā-ye-Dakan, Hyderabad, Hasan Press, 1331/1912. (Urdu)

Abū'l Hasan ibn Sayyid Muhȳ̄ al-dīn Bukhārī, Risāla-ye-'Aynak-e-Būqalmūn, ms, Salar Jung Library, Hyderabad, Tas. 261. (Persian)

Afzal Bēg Qāqshāl Awrangābādī, Tuhfat al-Shu'arā, ms, Salar Jung Library, Hyderabad, Tad. 8. (Persian)

Al-Hāj Muhammad 'Abd al-Hayy, Gulistān-e-Khuldābād, Awrangabad, Sawira Offset Printers, 1422/2001. (Urdu)

Altāf Husayn Hālīi, Yādgāar-e-Ghālib, 2 vols, Delhi, Maktaba Jāmi'at al-Mutīd, 1971. (Urdu, Persian)

'Amjad Husayn, Tārìkh-e-Dakan, mulaqab ba Riyāz al-rahmān, al-ma'rūf ba Tārīkh-e-'Amjadiyya, Haydarabad, Matba'a-ye-Khūrshīdiyya, 1293/1876. (Urdu)

Ghulām 'Al̄̄ Āzād Bilgrāmīe, Khazāna-ye-'Āmira, Lucknow, Matba'a-ye-Munshī Nawal Kishawr, 1287/1871. (Persian)

Ghulām 'Alī Āzād Bilgrāmī, Ma'āthir al-Kirām, Agra, Matba'a-ye-Mufīd-e-'Ām, 1328/1910. (Persian)

Ghulām 'Al̄̄ Āzād Bilgrāmī, Rawzat al-Awliȳā, Delhi, Liberty Art Press, 1996. (Persian)

Ghulām 'Alī Āzād Bilgrāmī, Subhat al-Marjān fī Āthār Hindūstān, 2 vols, Muhammad al-Nadw̄ī al-Sīwānī (ed.), Aligarh, Jāmi‘at 'Alīgarh al-Islāmiyya, 1976-80. (Arabic)

Ghulām 'Alī Qādirī, Mishkat al-Nubuwwat, 8 vols, trans. Abū’l Fazl Sayyid Mahmūd Qādirī, Haydarabad, A'jāz Printing Press, 1982. (Urdu)

Ghulām Chishtī, Dīwān-e-Ghulām Chisht̄̄ Ilīchpūurù, Elichpur, n.p., 1420/1999. (Persian/ Urdu)

Ghulām Imām Khān, Tārīkh-e-Khūrshīd Jāhī wa Tārīkh-e-Khujista Bunyād, Awrangabad, n.p., c.1318/1900. (Urdu/Persian)

Ghulām Sarwar Lāhawrī̄, Khazīnat al-Asfiȳa, 2 vols, Lucknow, Matba'a-ye-Munshī Nawal Kishawr, 1312/1894. (Urdu)

Gul Muhammad Ahmadpūrī, Takmila-ye-Siyar al-Awliyā, ms, K.A. Nizami Collection. (Persian)

Habīb 'Alī Shāh, Yār Khān Bahādur, Hab̄̄b al-Barāzikh, ms, Salar Jung Library, Hyderabad, Tas. 49. (Persian) 
Habīb 'Alī Shāh, Yār Khān Bahādur, Habīb al-Tālibìn, ms, Salar Jung Library, Hyderabad, Tas. 50. (Persian)

'Imād al-Mulk Ghāzī al-dīn Khān Fīrōz Jang III, Fakbriyyat al-Nizām, ms, shrine library of Nizām al-dīn Awrangābādī, Aurangabad. (Persian)

'Imād al-Mulk Ghāzī al-dīn Khān Fīrōz Jang III, Manāqib-e-Fakbriyya, ms, Salar Jung Library, Hyderabad, T-S. 31. (Persian)

'Ināyat Allāh Khān Awrangābādī, Tadbkira-ye-Riyāz Husayñ̄: Mardān-e-Āftāb 'Ālamtāb-e-Man, translated into Urdu by Āghā Mīrzā Bēg, Aurangabad, Mahāwīr P̄̄r, 1994. (Urdu)

Kāmgār Khān, Absān al-shamā'il, ms, Tawnsa Shrine Library, Tawnsa Sharif, Pakistan. (Persian) Translated into Urdu as Majālis-e-Kalīmī wa ahsan al-shamä'il, trans. Muhȳ̄ al-dīn Ahmad Sidīīì, Aurangabad, Super Offset Printers, 2003.

Kāmgār Khān, Malfüzāt-e-Shāh Nizām al-d̄̄n Awliyā Awrangābād̄̄, ms, Salar Jung Library, Hyderabad, Tas. 156/2. (Persian)

Khāksār Sabzawārī, Sawānih, ms, Asiatic Society of Bengal, Calcutta, Curzon Collection, ms 85. (Persian)

Mahmūd Bahrī, 'Arūse-e'Irfān, ms, Salar Jung Library, Hyderabad, Tas. 114. (Persian)

Mawlānā Qamar al-dīn (Awrangābādī), Nūr al-Karīmatayn, Kanpur, Matba'a-ye-Nizāmī, 1307/1889. (Persian)

Mīrzā Āghā Bēg and Sūfī Muhammad Mazhar Nizāmī Chishtī Qādirī, Awliyā Allāh: Gulshane-Hamawī, Aurangabad, Sun Rays Offset Printers, 2003.

Mīrzā Ghālib, Khutūte-e-Ghālib, Ghulām Rasūl Mehr (ed.), Lahore, Kitāb Manzil, n.d.

Mīrzā Muhammad Akhtar Dihlawī, Tadbkira-ye-Awliyāa-ye-Hind, 3 vols, Delhi, Mīwar Prēs, 1906. (Urdu)

Muhammad Haydar, Anwār-e-Tajalliyāt, ms, Salar Jung Library, Hyderabad, Tas. 18. (Persian)

Muhammad Ismā'īl Shāh Qādirī, A'zam al-Karāmāt, Aurangabad, Mu'īn Press, c.1340/1921. (Urdu)

Muhammad Kāzim ibn-i Muhammad Amīn Munshī, 'Ālamgīrnāma, Mawlw̄ī Khādim Husayn and Mawlawī 'Abd al-Hay (eds), Calcutta, Asiatic Society of Bengal, 1868. (Persian)

Muhammad Najīb Qādirī Nagawrī, Kitāb-e-A'rās (Makbzan-e-a'rās), Agra, n.p., 1300/1883. (Urdu)

Nizām al-dīn Awliyā Awrangābādī, Nizām al-qulūb, Delhi, Matba'a-ye-Mujtabā'̄î, 1309/1891-2. (Persian)

Nizām al-Mulk Āsaf Jāh, Wasiyat nāma-ye-Āsaf Jāh, ms, Salar Jung Library, Hyderabad, Hist. 454. (Persian)

Rawnaq 'Alī, Rawzat al-Aqtāb, Aurangabad, Sawira Offset, 1420/2000. (Urdu)

Sayyid Abū'l Hasan 'Ali Nadwīe, Tārīkh-e-Da'wat wa 'Azīmat, vol. 3, Lucknow, Lucknow Publishing House, 1398/1978. (Urdu)

Sayyid Ahmad Khan, Āthār al-Sanād̄̄e, Delhi, Matba'a-ye-Sayyid al-Akhbār, 1263/1846. (Urdu)

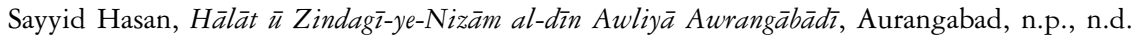
(Urdu)

Sayyid Imām al-dīn Naqwī Hanafī Gulshanābādī, Tadhkira-ye-Buzurgān-e-Dakan: Barakāt al-Awliyā, n.p., 1321/1903-4. (Urdu)

Shafī Awrangābādī (Lakshmī Narā' in), Untitled ('A Description of the City of Hyderabad and Aurangabad'), ms, British Library, Add. 26, 263. (Persian)

Shafīq Awrangābādī (Lakshmī Narā'in), Gul-e-Ra'nā, ms, Salar Jung Library, Hyderabad, Tad. 38. (Persian)

Shāh Kalīm Allāh Jahānābādī, Kashkūl, ms, Salar Jung Library, Hyderabad, Tas. 130. (Persian) 
Shāh Kalīm Allāh Jahānābādī, Maktūbāt-e-Kalīmī, Delhi, Matba'a-ye-Yūsufī, 1301/1884. (Persian)

Shāh Mahmūd Awrangābādī, Malfūzāt-e-Naqshbandiyya: Hālāt-e-Hazrat Bābā Shāh Musāfir Sāhib, Hyderabad, Nizāmat-e-'Umūr-e-Madhhabī-e-Sarkār-e-'Ālīi, 1358/1939-40. (Persian) Translated by Simon Digby as Sufis and Soldiers in Aurangzeb's Deccan, Delhi, Oxford University Press, 2001.

Sirāj Awrangābādī, Kulliyāt-e-Sirāj, 'Abd al-Qādir Sarwarī (ed.), repr. Delhi, Qawmī Kawnsil barāye Furūgh-e-Urdū Zabān, 1998. (Urdu)

Tārā Sāhib Qurēshī, Âftāb-e-Dakan, Aurangabad, n.p., c.1985. (Urdu)

Zahūr Khān Zahūr, Nūr al-Anwār, an Urdu translation of the parts of Khizān ū Babār of Bāhā' al-dīn Hasan 'Urūj related to Shāh Nūr, ms, Collection of Mohammad Abd al-Hayy, Aurangabad. (Urdu)

\section{Translations of primary sources into European languages}

Aurangzeb, 1908, Ruka'at-i-Alamgiri, or, Letters of Aurungzebe, trans. J.H. Bilimoria, London, Luzac \& Co.

Bhimsen, 1972, Tarikh-i-dilkasha (Memoirs of Bbimsen Relating to Aurangzib's Deccan Campaigns), trans. J. Sarkar, Bombay, Dept. of Archives, Govt. of Maharashtra.

Kalimullah Jahanabadi, 1909, Tasnim ul Touheed, or Unity of God, Madras, Hue \& Co.

Kalimullah Jahanabadi, 1910, The Scallop Shell, Madras, Ananda Press.

Kewal Ram, 1985, Tazkiratul-Umara of Kewal Ram, trans. S.M. Azizuddin Husain, Delhi, Munshiram Manoharlal.

Khafi Khan, 1975, Muntakhab al-Lubāb: Khafi Khan's History of 'Alamgir, trans. S. Moinul Haq, Karachi, Pakistan Historical Society.

Ni'mat Khan 'Ali, 1975, Chronicles of the Siege of Golkonda Fort (An Abridged Translation of the Wāqa'ī of Ni'mat Khan 'Ali', Delhi, Idarah-i Adabiyat-i Delli.

Nizam ad-din Awliya, 1992, Morals for the Heart, trans. B.B. Lawrence, New York, Paulist Press.

Sadik Isfahani, 1832, The Geographical Works of Sādik Isfahāni, trans. Sir William Ouseley, London, John Murray.

Saqi Must'ad Khan, 1990, Mā̄sir-i-'Ālamgīrī, trans. J.N. Sarkar, Calcutta, Asiatic Society of Bengal.

Shah Nawaz Khan, 1911-52, Ma'āthir al-umarāa, trans. H. Beveridge, revised by B. Prashad, Calcutta, Asiatic Society of Bengal.

Shir 'Ali (Afsus), 1871, Araish-i-mabfil; or, The Ornament of the Assembly, trans. H. Court, Allahabad, Pioneer Press.

\section{Archival documents and official publications}

Anonymous, 1783, 'Memoir Illustrative of the History, Geography and Statistics of the Deckan', British Library (OIOC), Mackenzie Collection: General, vol. XLIII.

Anonymous, 1798, 'Anecdotes of the Southern Courts of Hindostan or the Dekan by a Musulman in 1781-2, Communicated by the Resident at Hydrabad [sic] 1798', British Library (OIOC), Mackenzie Collection: General, vol. XLIII.

Anonymous, 1969, Bhir District Gazetteer, Bombay, Government of Maharashtra. 
Anonymous, 1977, Aurangabad District Gazetteer, Bombay, Government of Maharashtra.

Grant, J., 1782, 'Political Survey of the Deccan', British Library (OIOC), Hastings Collection, Add. Mss. 29, 209 (f. 385r-f. 451v).

Hunter, W.W., Cotton, J.S., Burn, R. and Meyer, W.S., 1908-31, Imperial Gazetteer of India, Oxford, Clarendon Press.

Lane-Smith, H., 1901-38, Papers of Rev. Henry Lane-Smith, CMS Collection, Unofficial Papers, Acc. 33, Special Collections Department, Birmingham University Library.

Sydenham, G., 1811, 'Gulbarga', British Library (OIOC), Mackenzie Collection: General, vol. XLIII.

\section{Secondary sources}

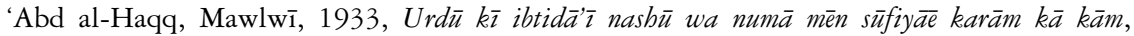
Aurangabad, Matba'a-ye Anjoman-e-Taraqī-ye-Urdū.

Akimushkin, O.F., 2001, 'A Rare Seventeenth Century Hagiography of the NaqshbandiyyaMujaddidiyya Shaykhs', Manuscripta Orientalia, 7, 1.

Alam, M., 1997, The Crisis of Empire in Mughal North India: Awadh \& the Punjab 1707-1748, Delhi, Oxford University Press.

Algar, H., 1990, 'A Brief History of the Naqshbandī Order', in M. Gaborieau, A. Popovic and T. Zarcone (eds), Naqshbandīs: Cheminements et situation actuelle d'un ordre mystique musulman, Istanbul, Isis Press.

Algar, H., 1990, 'Political Aspects of Naqshbandī History', in M. Gaborieau, A. Popovic and T. Zarcone (eds), Naqshbandīs: Cheminements et situation actuelle d'un ordre mystique musulman, Istanbul, Isis Press.

Ali, M., 1963, 'Ahmad Shāh Bābā: Father of the Nation', Afghanistan, 18.

Alvi, S.S., 1991, 'Qāzī Sanā’ Allāh Pānpatī, An Eighteenth Century Indian Sūfī-'Ālim: A Study of his Writings in their Sociopolitical Context', in W.B. Hallaq and D.P. Little (eds), Islamic Studies Presented to Charles J. Adams, Leiden, E.J. Brill.

Amladi, D.R. and Narkhede, P.N., n.d., Aurangabad: Queen of the Deccan, Bombay, Government of Maharashtra.

Anonymous, 1836, 'The Durgahs and Mahomedan Saints of Hindostan', Asiatic Journal, 19.

Anonymous, 1883, H.H. the Nizam's Tour in the Aurangabad District by the Special Correspondent of The Times of India, Bombay, Times of India Steam Press.

Anonymous, 1956, The Freedom Struggle in Hyderabad, 2 vols, Hyderabad, Hyderabad State Committee.

Ansari, S.F.D., 1992, Sufi Saints and State Power: The Pirs of Sind, 1843-1947, Cambridge, Cambridge University Press.

Arberry, A.J., 1950, Sufism: An Account of the Mystics of Islam, London, Allen and Unwin.

Asanova, G. and Dow, M., 2001, 'The Sarrāfān Baths in Bukhara', Iran, 39.

Asher, C.B., 1993, 'Sub-Imperial Palaces: Power and Authority in Mughal India', Ars Orientalis, 23.

Askari, S.H., 1976, Maktub and Malfuz Literature as a Source of Socio-political History, Patna, Mahboob Husain for Khuda Bakhsh Library.

Athar Ali, M., 1966, The Mughal Nobility Under Aurangzeb, London, Asia Publishing House.

Babs Mala, S., 1977, 'The Sufi Convent and its Social Significance in the Medieval Period of Islam', Islamic Culture, 51, 1.

Baldick, J., 2000, Animal and Shaman: Ancient Religions of Central Asia, London, I.B. Tauris. 
Balfour, E., 1885 (1858), The Cyclopaedia of India, London, Bernard Quaritch.

Baljon, J.M.S., 1989, 'Shah Waliullah and the Dargah', in C.W. Troll (ed.), Muslim Shrines in India: Their Character, History and Significance, Delhi, Oxford University Press.

Bauman, Z., 1996, 'From Pilgrim to Tourist - Or, a Short History of Identity', in S. Hall (ed.), Questions of Cultural Identity, London, Sage.

Bawa, V.K., 1996, Hyderabad under Salar Jang I, Delhi, S. Chand.

Bayly, C.A., 1997, Empire and Information: Intelligence Gathering and Social Communication in India, 1780-1870, Cambridge, Cambridge University Press.

Bayly, S., 1989, Saints, Goddesses and Kings: Muslims and Christians in South Indian Society, 1700-1900, Cambridge, Cambridge University Press.

Bayly, S., 2000, 'Cult Saints, Heroes, and Warrior Kings: South Asian Islam in the Making', in K.E. Yandell and J.J. Paul (eds), Religion and Public Culture, London, Curzon.

Beale, T.W., 1881, The Oriental Biographical Dictionary, Calcutta, Asiatic Society of Bengal.

Bilgrami, S.A.A., 1927, Landmarks of the Deccan: A Comprehensive Guide to the Archaeological Remains of the City and Suburbs of Hyderabad, Hyderabad, Government Central Press.

Bilgrami, S.H. and Willmott, C., 1883-4, Historical and Descriptive Sketch of His Highness the Nizam's Dominions, 2 vols, Bombay, Times of India Steam Press.

Blair, S.S., 1990, 'Sufi Saints and Shrine Architecture in the Early Fourteenth Century', Muqarnas, 7.

Blake, S.P., 1993, Shahjahanabad: The Sovereign City in Mughal India 1639-1739, Delhi, Cambridge University Press.

Brittlebank, K., 1997, Tipu Sultan's Search for Legitimacy: Islam and Kingship in a Hindu Domain, Delhi, Oxford University Press.

Brown, P., 1971, 'The Rise and Function of the Holy Man in Late Antiquity', Journal of Roman Studies, 61.

Buehler, A., 1996, 'The Naqshbandiyya in Timurid India: The Central Asian Legacy', Journal of Islamic Studies, 7, 2.

Buehler, A., 1997, 'Currents of Sufism in Nineteenth and Twentieth-Century Indo-Pakistan: An Overview', Muslim World, 87, 3-4.

Buehler, A., 1998, Sufi Heirs of the Prophet: The Indian Naqshbandi Brotherhood and the Rise of the Mediating Sufi Shaykh, Columbia, SC, University of South Carolina Press.

Campbell, C.A., 1898, Glimpses of Nizam's Dominions, Philadelphia, PA, n.p.

Cantwell Smith, W., 1950, 'Hyderabad: Muslim Tragedy', Middle East Journal, 4.

Carruthers, M., 1990, The Book of Memory: A Study in Medieval Culture, Cambridge, Cambridge University Press.

Chambert Loir, H. and Guillot, C. (eds), 1995, Le Culte des saints dans le monde musulman, Paris, Ecole Francaise d'Extrême-Orient.

Chander, S., 1987, 'From a Pre-Colonial Order to a Princely State: Hyderabad in Transition c. 1748-1865', unpubl. PhD thesis, Cambridge University.

Chandra, S., 1986, 'Cultural and Political Role of Delhi, 1675-1725', in R.E. Frykenberg (ed.), Delhi Through the Ages, Delhi, Oxford University Press.

Chandra, S., 1993, 'Some Religious Grants of Aurangzeb to Maths, in the State of Marwar', in S. Chandra, Mughal Religious Policies, the Rajputs and the Deccan, Delhi, Vikas Publishing House.

Chandra, S., 2003, Essays on Medieval Indian History, Delhi, Oxford University Press.

Chittick, W., 1992, 'Notes on Ibn 'Arabī's Influence in the Indian Sub-Continent', Muslim World, 82. 
Chodkiewicz, M., 1990, Quelques aspects des techniques spirituelles dans la tarīqa naqshbandiyya', in M. Gaborieau, A. Popovic and T. Zarcone (eds), Naqshband̄̄s: Cheminements et situation actuelle d'un ordre mystique musulman, Istanbul, Isis Press.

Chodkiewicz, M., 1993, Seal of the Saints: Prophethood and Sainthood in the Doctrine of Ibn 'A rabi, Cambridge, Islamic Texts Society.

Clancy-Smith, J., 1993, 'The Man With Two Tombs: Muhammad Ibn 'Abd Al-Rahman, Founder of the Algerian Rahmaniyya, c.1715-1798', in G.M. Smith and C.W. Ernst (eds), Manifestations of Sainthood in Islam, Istanbul, Isis Press.

Cole, J.R.I., 1988, Roots of North Indian Shī'ism in Iran and Iraq: Religion and State in Awadh, 1722-1859, Berkeley, CA, University of California Press.

Cornell, V., 1999, The Dominion of the Saint: Power and Authority in Moroccan Mysticism, Austin, TX, University of Texas Press.

Crooke, W., 1926, Religion and Folklore of Northern India, Oxford, Oxford University Press.

Currie, P.M., 1989, The Shrine and Cult of Mu'īn al-Dīn Chishtī of Ajmer, Delhi, Oxford University Press.

Dalrymple, W., 2002, The White Mughals: Love and Betrayal in Eighteenth-Century India, London, HarperCollins.

Das, H., 1959, The Norris Embassy to Aurangzib, Calcutta, Firma K.L. Mukhupadhyay.

David, M.D., 2001, Missions: Cross-Cultural Encounter and Change in Western India, Delhi, ISPCK.

Denny, F.M., 1988, 'God's Friends: The Sanctity of Persons in Islam', in R. Kieckhefer and G.D. Bond (eds), Sainthood, Berkeley and Los Angeles, CA, University of California Press.

Desai, Z.A., 1973-4, 'Mughal Architecture of the Deccan', in H.K Sherwani and P.M. Joshi (eds), History of Medieval Deccan (1295-1724), 2 vols, Hyderabad, Govt. of Andhra Pradesh.

Desai, Z.A., 1989, 'The Major Dargahs of Ahmadabad', in Troll (ed.), Muslim Shrines in India: Their Character, History and Significance, Delhi, Oxford University Press.

De Tassy, G., 1997, Muslim Festivals in India and Other Essays, trans. M. Waseem, Delhi, Oxford University Press.

DeWeese, D., 1988, 'The Eclipse of the Kubraviyah in Central Asia', Iranian Studies, 21.

DeWeese, D., 1999, 'The Yasavī Order in Persian Hagiography in Seventeenth-Century Central Asia: 'Ālim Shaykh of 'Alīyābād and his Lamahāt min nafahāt al-quds', in L. Lewisohn and D. Morgan (eds), The Heritage of Sufism, vol. 3, Late Classical Persianate Sufism (1501-1750), The Safavid and Mughal Period, Oxford, Oneworld Publications.

DeWeese, D., 2000, 'Sacred History for a Central Asian Town. Saints, Shrines and Legends of Origin in Histories of Sayrām, 18th to 19th Centuries', Révue des Mondes Musulmans et de la Méditteranée, 89-90.

DeWeese, D., 2000, 'Sacred Places and "Public" Narratives: The Shrine of Ahmad Yasavī in Hagiographical Traditions of the Yasavī Sufi Order, 16th to 17th Centuries', Muslim World, 90,3 and 4 .

Dickie, J., 1985, 'The Mughal Garden: Gateway to Paradise', Muqarnas, 3.

Digby, S., 1983, 'Early Pilgrimages to the Graves of Mu'in al-Din and other Chishti Shaikhs', in M. Israel and N.K. Wagle (eds), Islamic Society and Culture, Delhi, Manohar.

Digby, S., 1986, 'Tabarrukat and Succession Among the Great Chishti Shaykhs', in R.E. Frykenberg (ed.), Delhi Through the Ages: Essays in Urban History, Culture and Society, Delhi, Oxford University Press.

Digby, S., 1990, 'The Naqshbandīs in the Deccan in the Late Seventeenth and Early Eighteenth Century A.D.: Bābā Palangpōsh, Bābā Musāfir and Their Adherents', in M. Gaborieau, A. Popovic and T. Zarcone (eds), Naqshbandīs: Cheminements et situation actuelle d'un ordre mystique musulman, Istanbul, Isis Press. 
Digby, S., 1994, 'To Ride a Tiger or a Wall? Strategies of Prestige in Indian Sufi Legend', in W.M. Callewaert and R. Snell (eds), According to Tradition: Hagiographical Writing in India, Wiesbaden, Harrassowitz.

Digby, S., 1994, 'Anecdotes of a Provincial Sufi of the Delhi Sultanate, Khwāja Gurg of Kara', Iran, 32 .

Digby, S., 1998, 'Before the Bābās Came to India: A Reconstruction of the Earlier Lives of Bābā Sa'īd Palangpōsh and Bābā Muhammad Musāfir in "Wilāyat" ', Iran, 36.

Eaton, R.M., 1973, 'The Court and the Dargāh in the Seventeenth Century Deccan', Indian Economic and Social History Review, 10.

Eaton, R.M., 1978, Sufis of Bijapur, 1300-1700: Social Roles of Sufis in Medieval India, Princeton, NJ, Princeton University Press.

Eaton, R.M., 1984, 'The Political and Religious Authority of the Shrine of Bābā Fārid', in B.D. Metcalf (ed.), Moral Conduct and Authority: The Place of Adab in South Asian Islam, Berkeley, CA, University of California Press.

Eaton, R.M., 1993, The Rise of Islam and the Bengal Frontier, 1204-1760, Berkeley, CA, University of California Press.

Eaton, R.M., 2000, 'The Articulation of Islamic Space in the Medieval Deccan', in I.A. Bierman (ed.), Islam on the Margins, Los Angeles, CA, Center for Near Eastern Studies UCLA.

Ebeling, K., 1973, Ragmala Painting, Basel, Ravi Kumar.

Elias, J.J., 2000, 'Sufi Saints and Shrines in Muslim Society', Muslim World, 90, 3 and 4.

Ernst, C.W., 1992, Eternal Garden: Mysticism, History, and Politics at a South Asian Sufi Center, Albany, NY, State University of New York Press.

Ernst, C.W., 1993, 'An Indo-Persian Guide to Sufi Shrine Pilgrimage', in G.M. Smith and C.W. Ernst (eds), Manifestations of Sainthood in Islam, Istanbul, Isis Press.

Ernst, C.W., 1995, 'India as a Sacred Islamic Land', in D.S. Lopez (ed.), Religions of India in Practice, Princeton, NJ, University of Princeton Press.

Ernst, C.W., 1996, 'Royal Policy and Patronage of Sufi Shrines in Mughal Revenue Documents from Khuldabad', in A.R. Kulkarni, M.A. Nayeem and T.R. de Souza (eds), Medieval Deccan History: Commemoration Volume in Honour of P.M. Joshi, Bombay, Popular Prakashan.

Ernst, C.W., 1999, 'Chishtī Meditation Practices of the Later Mughal Period', in Lewisohn and Morgan.

Ernst, C.W. and Lawrence, B.B., 2003, Sufi Martyrs of Love: The Chishti Order in South Asia and Beyond, London, Palgrave Macmillan.

Ewing, K.P., 1983, 'The Politics of Sufism: Redefining the Saints of Pakistan', Journal of Asian Studies, 42.

Faroqhi, S., 1986, 'Agricultural Activities in a Bektashi Center: the Tekke of Kizil Deli 1750-1830', in S. Faroqhi, Peasants, Dervishes and Traders in the Ottoman Empire, London, Variorum Reprints.

Faroqhi, S., 1988, 'Agricultural Crisis and the Art of Flute-Playing: The Worldly Affairs of the Mevlevi Dervishes', Turcica, 20.

Faroqhi, S., 1993, 'Sainthood as a Means of Self-defense in Seventeenth-Century Ottoman Anatolia', in Smith and Ernst.

Faruqi, S.R., 2001, Early Urdu Literary History and Culture, Delhi, Oxford University Press.

Fathulla Khan, M., 1938, 'The Nizams as Men of Letters', Islamic Culture, 12, 4.

Fernandes, L., 1988, The Evolution of a Sufi Institution in Mamluk Egypt: The Khanqah, Berlin, Klaus Schwarz. 
Foltz, R., 1996, 'The Central Asian Naqshbandiyya Connections of the Mughal Emperors', Journal of Islamic Studies, 7, 2.

Foltz, R., 2001, Mughal India and Central Asia, Karachi, Oxford University Press.

Frenkel, Y., 2001, 'Baybars and the Sacred Geography of Bilād al-Shām: A Chapter in the Islamization of Syria's Landscape', Jerusalem Studies in Arabic and Islam, 25.

Friedmann, Y., 1971, Shaykh Ahmad Sirbind̄̄, Montreal, McGill-Queen's University Press.

Friedmann, Y., 1990, 'The Naqshbandīs and Awrangzēb: A Reconsideration', in M. Gaborieau

A. Popovic and T. Zarcone (eds), Naqsbbandīs: Cheminements et situation actuelle d'un ordre mystique musulman, Istanbul, Isis Press.

Furbank, P.N., 1979, E.M. Forster: A Life, Oxford, Oxford University Press.

Fusfeld, W., 1981, 'The Shaping of Sufi Leadership in Delhi: The Naqshbandiyya-Mujaddidiyya, 1750-1920', unpubl. PhD dissertation, University of Pennsylvania.

Fusfeld, W., 1988, 'The Boundaries of Islam and Infidelity', in K. Ewing (ed.), Shari' at and Ambiguity in South Asian Islam, Berkeley, CA, University of California Press.

Gaborieau, M., 1989, 'A Nineteenth-Century Indian "Wahabi” Tract Against the Cult of Muslim Saints: Al-Balagh al-Mubin', in Troll.

Gaborieau, M., 1996, 'Les Saints, les eaux et les récoltes en Inde’, in M.A. Amir-Moezzi (ed.), Lieux d'islam, Paris, Éditions Autrement.

Gaborieau, M., Popovic, A. and Zarcone, T. (eds), 1990, Naqshbandīs: Cheminements et situation actuelle d'un ordre mystique musulman, Istanbul, Isis Press.

Gellner, E., 1969, Saints of the Atlas, London, Weidenfeld and Nicolson.

Geoffroy, E., 1995, Le Soufisme en Egypte et en Syrie, Damascus, Institut Français de Damas.

Gill, M. and Fergusson, J., 1864, One Hundred Stereoscopic Illustrations of Architecture and Natural History in Western India, London, Cundall, Downes and Company.

Gilmartin, D., 1984, 'Shrines, Succession and Sources of Moral Authority', in B.D. Metcalf (ed.), Moral Conduct and Authority: The Place of Adāb in South Asian Islam, Berkeley, CA, University of California Press.

Gilmartin, D. and Lawrence, B.B. (eds), 2000, Beyond Turk and Hindu: Rethinking Religious Identities in Islamicate South Asia, Gainesville, FL, University of Florida Press.

Gokhale, B.G., 1984, 'Hindu Responses to the Muslim Presence in Maharashtra', in Y. Friedmann (ed.), Islam in Asia, vol. 1, South Asia, Boulder, CO/Jerusalem, Magnes Press/Hebrew University.

Goldziher, I., 1966, 'Veneration of Saints in Islam', in S.M. Stern (ed.), Muslim Studies, vol. 2, London, George Allen and Unwin.

Golombek, L., 1974, 'The Cult of Saints and Shrine Architecture in the Fourteenth Century', in D.K. Kouymjian (ed.), Near Eastern Numismatics, Iconography, Epigraphy and History: Studies in Honour of George C. Miles, Beirut, American University of Beirut.

Gommans, J.J.L., 1999, The Rise of the Indo-Afghan Empire, c.1710-1780, Delhi, Oxford University Press.

Gonnella, J., 1995, Islamische Heiligenverehrung im urbanen Kontext am Beispiel von Aleppo (Syrien), Berlin, Klaus Schwarz.

Gordon, S., 1993, The Marathas (New Cambridge History of India, II. 4), Cambridge, Cambridge University Press.

Gordon, S., 1994, 'Burhanpur: Entrepot and Hinterland, 1650-1750', in Gordon, S., Marathas, Marauders, and State Formation in Eighteenth Century India, Delhi, Oxford University Press.

Gordon, S., 2000, 'Maratha Patronage of Muslim Institutions in Burhanpur and Khandesh', in Gilmartin and Lawrence. 
Green, N.S., 2003, 'Migrant Sufis and Sacred Space in South Asian Islam', Contemporary South Asia, 12, 4 .

Green, N.S., 2004, 'A Persian Sufi in British India: The Travels of Mīrzā Hasan Safí 'Alī Shāh (1251/1835-1316/1899)', Iran, 42.

Green, N.S., 2004, 'Emerging Approaches to the Sufi Traditions of South Asia: Between Texts, Territories and the Transcendent', South Asia Research, 24, 2.

Green, N.S., 2004, 'Geography, Empire and Sainthood in the Eighteenth Century Muslim Deccan', Bulletin of the School of Oriental and African Studies, 67, 2.

Green, N.S., 2004, 'Auspicious Foundations: The Patronage of Sufi Institutions in the Late Mughal and Early Asaf Jah Deccan', South Asian Studies, 20.

Green, N.S., 2004, 'Oral Competition Narratives of Muslim and Hindu Saints in the Deccan', Asian Folklore Studies, 63, 2.

Green, N.S., 2004, 'Stories of Saints and Sultans: Re-membering History at the Sufi Shrines of Aurangabad', Modern Asian Studies, 38, 2.

Green, N.S., 2005, 'Mystical Missionaries in Hyderabad State: Mu'īn Allāh Shāh and his Sufi Reform Movement', Indian Economic and Social History Review, 41, 2.

Green, N.S. (forthcoming), 'Shi' ism, Sufism and Sacred Space in the Deccan: CounterNarratives of Saintly Identity in the Cult of Shah Nur', in A. Monsutti, S. Naef and F. Sabahi (eds), The Other Shi'ites, London, I.B. Tauris.

Gross, J., 1988, 'The Economic Status of a Timurid Sufi Shaykh: A Matter of Conflict or Perception?' Iranian Studies, 21.

Gross, J., 1990, 'Multiple Roles and Perceptions of a Sufi Shaikh: Symbolic Statements of Political and Religious Authority', in M. Gaborieau A. Popovic and T. Zarcone (eds), Naqshbandīs: Cheminements of situation actuelle d'un ordre mystique musulman, Istanbul, Isis Press.

Gross, J., 1992, 'Authority and Miraculous Behavior: Reflections on Karāmāt Stories of Khwāja 'Ubaydullāh Ahrār', in L. Lewisohn (ed.), The Legacy of Medieval Persian Sufism, London, Khaniqahi Nimatullahi Publications.

Guenther, A.M., 2003, 'Hanafi Fiqh in Mughal India: The Fatawa-i 'Alamgiri', in R.M. Eaton (ed.), India's Islamic Traditions, 711-1750, Delhi, Oxford University Press.

Hadi, N., 1995, Dictionary of Indo-Persian Literature, Delhi, Indira Gandhi National Centre for the Arts.

Haig, T.W., 1907, Historic Landmarks of the Deccan, Allahabad, n.p.

Hamidullah, M., 1942, 'Literary Treasures of Aurangabad (Two Important Collections of Rare MSS)', Islamic Culture, 16.

Hasan, M., 1959, 'Bahadur Shah II, his Relations with the British and the Mutiny', Islamic Culture, 33 .

Haywood, J.A., 1964, 'Wali Dakhani and the Development of Dakhani-Urdu Sufi Poetry', Acta Orientalia, 28, 1-2.

Hermansen, M.K., 1997, 'Religious Literature and the Inscription of Identity: The Sufi Tazkira Tradition in Muslim South Asia', Muslim World, 87, 3-4.

Hermansen, M.K., 1999, 'Contemplating Sacred History in Late Mughal Sufism: The Case of Shāh Walī Allāh of Delhi', in Lewisohn and Morgan.

Hermansen, M.K. and Lawrence, B.B., 2000, 'Indo-Persian Tazkiras as Memorative Communications', in D. Gilmartin and B.B. Lawrence (ed.), Beyond Turk and Hindu: Rethinking Religious Identities in Islamicate South Asia, Gainsville, FL, University of Florida Press.

Husain, A., 1972, 'The Family of Shaikh Salim Chishti during the Reign of Jehangir', in K.A. Nizami (ed.), Medieval India - A Miscellany, vol. 2, Delhi, Asia Publishing House. 
Husain, A.A., 2000, A Scent in the Islamic Garden: A Study of Deccani Urdu Literary Sources, Karachi, Oxford University Press.

Husain, Y., 1963, The First Nizam: The Life and Times of Nizāmu'l-Mulk Āsaf Jāh I, London, Asia Publishing House.

Islam, R., 2002, Sufism in South Asia: Impact on Fourteenth Century Muslim Society, Karachi, Oxford University Press.

Ivanow, W., 1924, Concise Descriptive Catalogue of the Persian Manuscripts in the Curzon Collection, Asiatic Society of Bengal, Calcutta, Asiatic Society of Bengal.

Jabbar, M.A., n.d., Glimpses of Panchakee, Bombay, Bhal Malji.

Jayaram, R., 1998, Administrative System under the Nizams, 1853-1935, Bangalore, Ultra Publications.

Kate, P.V., 1987, Marathwada Under the Nizams, 1724-1948, Delhi, Mittal.

Khalidi, O., 1985, Hyderabad State under the Nizams, 1724-1948, Wichita, KS, Hyderabad Historical Society.

Khalidi, O., 1987, Dakan under the Sultans, 1296-1724: A Bibliography of Monographic and Periodical Literature, Wichita, KS, Hyderabad Historical Society.

Khalidi, O. (ed.), 1988, Hyderabad: After the Fall, Wichita, KS, Hyderabad Historical Society.

Khalidi, O., 1997, 'The Hadhrami Role in the Politics and Society of Colonial India, 1750s-1950s', in U. Freitag and W.G. Clarence-Smith (eds), Hadhrami Traders, Scholars, and Statesmen in the Indian Ocean, 1750-1960, Leiden, E.J. Brill.

Khan, B.M., 1997, Tārīkh-e-Awliyā-ye-Kirām-e-Burhānpūr, Burhanpur, Hakim al-din Khan. (Urdu)

Khan, K., 1928, 'Sufi Orders of the Deccan', Muslim World, 18.

Khan, M.A., 1987, 'Intergenerational Mobility among Muslims in Aurangabad: a South Indian City', Journal of the Institute of Muslim Minority Affairs, 8.

Khan, M.A., 1995, 'Social Change among the Muslims of Awrangabad City', in A.A. Engineer (ed.), Problems of Muslim Women in India, Hyderabad, Orient Longman.

Khan, Y.H., 1963, The First Nizam: the Life and Times of Nizamu'l Mulk Asaf Jah I, London, Asia Publishing House.

Khusro, A.M., 1958, Economic and Social Effects of Jagirdari Abolition and Land Reforms in Hyderabad, Hyderabad, Osmania University.

Kiyān̄̄, M., 1369/1990, Tārīkh-e-khānqāh dar İ̃ān, Tehran, Tahūrī. [Persian]

Kozlowski, G.C., 1985, Muslim Endowments and Society in British India, Cambridge, Cambridge University Press.

Kumar, R., 1999, 'Political Letters of Shah Wali Ullah', in R. Kumar (ed.), Survey of Medieval India, vol. 9, Nadir Shah and Anarchy India, Delhi, Anmol Publications.

Lang, H., 1992, Der Heiligenkult in Marokko: Formen und Funktionen der Wallfahrten, Passau, Passavia Universitätsverlag.

Lawrence, B.B., 1978, Notes from a Distant Flute: The Extant Literature of Pre-Mughal Indian Sufism, Tehran, Imperial Iranian Academy of Philosophy.

Lawrence, B.B., 1982, 'Islam in India: The Function of Institutional Sufism in the Islamization of Rajasthan, Gujarat and Kashmir', Contributions to Asian Studies, 17.

Lawrence, B.B., 1983, 'The Early Chishtī approach to Samā", in M. Israel and N.K. Wagle (eds), Islamic Society and Culture, Delhi, Munshiram.

Lawrence, B.B., 1999, 'Veiled Opposition to Sufis in Muslim South Asia: Dynastic Manipulation of Mystical Brotherhoods by the Great Mughal', in F. De Jong and B. Radtke (eds), Islamic Mysticism Contested: 13 Centuries of Controversies and Polemics, Leiden, E.J. Brill. 
Leonard, K., 1978, 'Hyderabad: The Mulki-Non-Mulki Conflict', in R. Jeffrey (ed.), People, Princes and Paramount Power: Society and Politics in the Indian Princely States, Delhi, Oxford University Press.

Lewisohn, L. (ed.), 1992, The Legacy of Medieval Persian Sufism, London, Khanaqahi Nimatullahi Publications.

Lewisohn, L. (ed.), 1993, Classical Persian Sufism: From its Origins to Rumi, London, Khanaqahi Nimatullahi Publications.

Lewisohn, L. and Morgan, D. (eds), 1999, The Heritage of Sufism, vol. 3, Late Classical Persianate Sufism (1501-1750), Oxford, Oneworld.

Liebeskind, C., 1998, Piety on its Knees: Three Sufi Traditions in South Asia in Modern Times, Delhi, Oxford University Press.

Lorenzen, D.N., 1978, 'Warrior Ascetics in Indian History', Journal of the American Oriental Society, 97.

Luther, N., 1997, Hyderabad, Delhi, Government of India Publications Division.

Lynton, H.R. and Rajan, M., 1974, The Days of the Beloved, Berkeley, CA, University of California Press.

Magrabi, S.S.Y., 1981, Aurangabad's Old Water Supply System of Aqueducts, Aurangabad, Yousufuddin Magrabi.

Malik, Z., 1977, The Reign of Muhammad Shah, 1719-1748, Bombay, Asia Publishing House.

Malik, Z., 1998, 'Social Origins of the Late Eighteenth Century Indo-Persian Historiographers: Perspectives and Responses', in N. Ahmad and I.H. Siddiqui (eds), Islamic Heritage in South Asian Subcontinent, vol. 1, Jaipur, Publication Scheme.

Manucci, N., 1907-8, Storia do Mogor or Mogul India, 1653-1708, trans. W. Irvine, London, John Murray.

Manucci, N., 1999, A Pepys of Mughal India (1653-1708), Delhi, Srishti Publications.

Martin, F., 1983, India in the 17th Century (Social, Economic and Political) - Memoirs of Francois Martin (1670-1694), vol.1, pt 2 (1674-81), trans. and edited by L. Varadarajan, Delhi, Munshiram.

Massignon, L., 1908, 'Les Saints musulmans enterrés à Baghdad', Révue de l'Histoire des Religions, 58, 2.

Matringe, D., 2001, 'Ādāb al-Sūfìya: les règles de vie dans les couvents soufis de l'Inde medievale', Journal Asiatique, 289, 1.

Mayaram, S., 1997, Resisting Regimes: Myth, Memory and the Shaping of a Muslim Identity, Delhi, Oxford University Press.

Metcalf, B.D., 1982, Islamic Revival in British India: Deoband, 1860-1900, Princeton, NJ, Princeton University Press.

Michell, G. (ed.), 1986, Islamic Heritage of the Deccan, Bombay, Marg.

Michell, G. and Zebrowski, M., 1999, Architecture and Art of the Deccan Sultanates (New Cambridge History of India, 1:7), Cambridge, Cambridge University Press.

Mojaddedi, J.A., 2001, The Biographical Tradition in Sufism: The Tabaqat Genre from al-Sulami to Jami, London, Curzon.

Muhammad, K.K., 1986, 'The Houses of the Nobility in Mughal India', Islamic Culture, 60.

Nakash, Y., 1995, 'The Visitation of the Shrines of the Imams and the Shi' 1 Mujtahids in the Early Twentieth Century', Studia Islamica, 81.

Naqshbandī, H., 1417/1996, Rūh al-'Ināyat, Balapur, Rashid Book Depot. (Urdu)

Nasīm, Wahīda, 1992, Shāhān-e-be-taj, Karachi, Maktaba-ye-Āsafiyya, 1988.

Nasr, S.V.R., 1996, Mawdudi and the Making of Islamic Revivalism, Oxford, Oxford University Press. 
Nayeem, M.A., 1985, Mughal Administration of Deccan Under Nizamul Mulk Asaf Jah (1720-48 AD), Delhi, Jaico Publishing.

Nayeem, M.A., 1987, The Splendour of Hyderabad: Last Phase of an Oriental Culture (1591-1948 AD), Bombay, Jaico Publishing.

Nayeem, M.A., 1997, 'Political Status of Nizamu'l Mulk Asaf Jah-I in the Deccan (1713-1748 AD)', in M. Taher (ed.), Encyclopaedic Survey of Islamic Culture, vol. 6, Muslim Rule in Deccan, Delhi, Anmol Publications.

Nizami, F.A., 1983, 'Madrasahs, Scholars and Saints: Muslim Response to the British Presence in Delhi and the Upper Doab, 1803-1857', unpubl. DPhil. thesis, University of Oxford.

Nizami, K.A., n.d., art. 'Ahmadpūrī, Gol Mohammad', in Encyclopaedia Iranica.

Nizami, K.A., 1973-4, 'Sufi Movement in the Deccan', in H.K. Sherwani and P.M. Joshi (eds), History of Medieval Deccan (1295-1724), 2 vols, Hyderabad, Govt. of Andhra Pradesh.

Nizami, K.A., 1979, Review of R.M. Eaton, Sufis of Bijapur, Islamic Culture, 53, 4.

Nizāmī, K.A., 1980-5, Tārākkh-e-Mashā’ikh-e-Chisht, Delhi, Idāra-ye-Adabiyyat-e-Dillī (Urdu).

Parodi, L.E., 1998, 'The Bibi-ka Maqbara in Aurangabad: A Landmark of Mughal Power in the Deccan', East and West, 48, 3-4.

Phillott, D.C., 1908, 'Note on the Shrine at Taunsa', Journal of the Asiatic Society of Bengal, 4, 1.

Pitt-Rivers, J.A., 1971, The People of the Sierra, Chicago, IL, University of Chicago Press.

Pourjavady, N. and Lamborn Wilson, P., 1974, 'The Descendants of Shāh Ni'matullāh Walī', Islamic Culture, 48, 1.

Prasad, D., 1969, Saints of Telangana, Hyderabad, Abul Kalam Azad Oriental Research Institute.

Quraishi, S. (ed.), 1997, Cry for Freedom: Proclamations of Muslim Revolutionaries of 1857, Lahore, Sang-e-Meel Publications.

Qureshi, D.G., 1999, Tourism Potential in Aurangabad, Delhi, Bharatiya Kala Prakashan.

Radtke, B., 1993, 'The Concept of wilaya in Early Sufism', in Lewisohn.

Radtke, B., 1996, 'Sufism in the Eighteenth Century: An Attempt at a Provisional Appraisal', Die Welt des Islams, 36, 3.

Radtke, B. and O'Kane, J., 1996, The Concept of Sainthood in Early Islamic Mysticism, London, Curzon.

Raf'at, Mubāriz al-dīn, n.d. (c.1957), Panchakkī-ye-Awrangābād, Hyderabad, Matba'a-yeIbrāhīmiyya. (Urdu)

Ramar Char, S., 1939, 'Education in Hyderabad', Modern Review, 66.

Ramusack, B.N., 2004, The Indian Princes and Their States (New Cambridge History of India, III 6), Cambridge, Cambridge University Press.

Ramzan, S., 1982, 'Medieval Aurangabad: A Cultural Study', unpubl. PhD dissertation, Marathwada University.

Rao, P.S.M., 1963, Eighteenth Century Deccan, Bombay, Popular Prakashan.

Reeves, E.B., 1990, The Hidden Government: Ritual, Clientelism and Legitimation in Northern Egypt, Salt Lake City, UT, University of Utah Press.

Regani, S., 1963, Nizam-British Relations, 1724-1857, Hyderabad, Booklovers Private Ltd.

Rizvi, K., 2000, “'Its Mortar Mixed with the Sweetness of Life”: Architecture and Ceremonial at the Shrine of Safī al-dīn Ishāq Ardabīlī During the Reign of Shāh Tahmāsb I', Muslim World, 90, 3 and 4.

Rizvi, S.A.A., 1978-83, A History of Sufism in India, 2 vols, Delhi, Munshiram.

Rizvi, S.A.A., 1980, Shāh Wal̄̄ Allāh and his Times, Canberra, Ma'rifat Publishing House. 
Robinson, C., 1999, 'Prophecy and holy men in early Islam', in J. Howard-Johnston and P.A. Hayward (eds), The Cult of the Saints in Late Antiquity and the Middle Ages, Oxford, Oxford University Press.

Ross, M.C., 1998, 'Land-Taking and Text-Making in Medieval Iceland', in S. Tomasch and S. Gilles (eds), Text and Territory: Geographical Imagination in the European Middle Ages, Philadelphia, PA, University of Pennsylvania Press.

Royce, W.R., 1979, 'Mir Ma'sum 'Ali Shah and the Ni'mat Allāhi Revival, 1776-77 to 1796-97', unpubl. PhD dissertation, Princeton University.

Russell, R. and Islam, K. (ed. and trans.), 1969, Ghalib 1797-1869, vol. 1, Life and Letters, London, George Allen and Unwin.

Sajun Lal, K., 1951, Studies in Deccan History, Madras, Business Week Press.

Sanyal, U., 1996, Devotional Islam and Politics in British India: Ahmad Riza Khan Barelwi and His Movement, 1870-1920, Delhi, Oxford University Press.

Sardesai, G.S. (ed.), 1932, Selections from the Peshwa Daftar, vol. 25, Bombay, Government Central Press.

Sardesai, G.S., 1933 (1932), Handbook to the Records in the Alienation Office, Poona (Selections from the Peshwa Daftar, No. 25), Bombay, Government Central Press.

Schimmel, A., 1982, Islam in India and Pakistan (Iconography of Religions XXII, 9), Leiden, E.J. Brill.

Schimmel, A., 1992, 'A dervish in the guise of a prince: Khān-i Khānān 'Abdur Rahīm as a Patron', in B. Stoler-Miller (ed.), The Powers of Art: Patronage in Indian Culture, Oxford, Oxford University Press.

Schimmel, A., 2000, Im Reich der Grossmoguln, Munich, Beck.

Schwerin, K.G., 1980, Indirekte Herrschaft und Reformpolitik im indischen Fürstenstaat Hyderabad, 1853-1911, Wiesbaden, Steiner.

Schwerin, K.G., 1984, 'Saint Worship in Indian Islam: The Legend of Martyr Salar Masud Ghazi', in I. Ahmad (ed.), Ritual and Religion Among Muslims in India, Delhi, Manohar.

Seely, J.B., 1824, The Wonders of Ellora, London, G. Whittaker and W.B. Whittaker.

Ser, S.N. (ed.), 1949, Indian Travels of Thevenot and Careri: being the third part of the travels of M. de Thevenot into the Levant and the third part of a voyage round the world by Dr. John Francis Gemelli Careri, Delhi, National Archives of India.

Seth, D.R., 1957, 'Life and Times of Malik Ambar', Islamic Culture, 31.

Shackle, C., 2005, 'Urdu Poetry as a Vehicle for Islamic Re-Expression', in H. Kilpatrick and G. Abramson (eds), Religion and Religiosity in Modern Muslim and Jewish Literatures, London, RoutledgeCurzon.

Shackle, C., 2005, art. 'Walī', in Encyclopaedia of Islam, 2nd edition, Leiden, E.J. Brill.

Shafi i, M., 1929, 'An Afghan Colony at Qusur', Islamic Culture, 3, 3.

Shakeb, M.Z.A., 1999, 'The Role of the Sufis in the Changing Society of the Deccan, $1500-1750$ ', in Lewisohn and Morgan.

Sherwani, H.K and Joshi, P.M. (eds), 1973-4, History of Medieval Deccan (1295-1724), 2 vols, Hyderabad, Govt. of Andhra Pradesh.

Sherwani, H.K., 1974, History of Qutb Shabi Dynasty, Delhi, Munshiram.

Shurreef, J., 1991 (1863), Qanoon-e-Islam, or the Customs of the Mussulmans of India, trans. G.A. Herklots, Delhi, Asian Educational Services.

Siddiqi, M., n.d., art. 'Āzad Belgrāmī', in Encyclopaedia Iranica.

Siddiqi, M.S., 1989, The Bahmani Sufis, Delhi, Idarah-i Adabiyat-i Delli.

Siddiqui, M.H., 1979, The Memoirs of Sufis Written in India, Baroda, University of Baroda Publications. 


\section{BIBLIOGRAPHY}

Siddiqui, M.Z., n.d., art. 'Awrangābādī, Shah Nezām-al-dīn', in Encyclopaedia Iranica.

Siddiqui, M.Z., 1971, 'The Resurgence of the Chishti Silsilah in the Punjab during the Eighteenth Century', in Proceedings of the Indian History Congress 1970, Delhi.

Smith, G.M. and Ernst, C.W. (eds), 1993, Manifestations of Sainthood in Islam, Istanbul, Isis Press.

Spear, P., 1951, Twilight of the Mughals: Studies in Late Mughal Delhi, Cambridge, Cambridge University Press.

Storey, C.A., 1927-71, Persian Literature: A Bio-bibliographical Survey, 2 vols, London, Luzac \& Co. Subtelny, M.E., 1994, 'The Cult of 'Abdullāh Ansārī Under the Timurids', in C. Bürgel and A. Giese (eds), God is Beautiful and He Loves Beauty (Festschrift for Annemarie Schimmel), Bern, Peter Lang.

Suvorova, A., 2000, Masnavi: A Study of Urdu Romance, Karachi, Oxford University Press.

Taylor, C.S., 1990, 'Sacred History and the Cult of Muslim Saints in Late Medieval Egypt', Muslim World, 80, 2.

Taylor, C.S., 1999, In the Vicinity of the Righteous: Ziyara and the Veneration of Muslim Saints in Late Medieval Egypt, Leiden, E.J. Brill.

Taylor, P.M., 1837, Sketches in the Deccan, London, Charles Tilt.

Tirmizi, S.A.I., 1989, 'Mughal Documents Relating to the Dargah of Khwaja Mu'inuddin Chishti', in Troll.

Trimingham, J.S., 1971, The Sufi Orders in Islam, Oxford, Clarendon Press.

Troll, C.W. (ed.), 1989, Muslim Shrines in India: Their Character, History and Significance, Delhi, Oxford University Press.

Umar, M., 1993, Islam in Northern India During the Eighteenth Century, Delhi, Manoharlal Munshiram.

Vaikuntham, Y., 1990, 'Oriental Culture and the Raj (A Study of Hyderabad between 1858-1911)', in Proceedings of the Indian Historical Congress, 51st Session (Calcutta University), Delhi.

Van Bruinessen, M., 1991, 'Haji Bektash, Sultan Sahak, Shah Mina Sahib and Various Avatars of a Running Wall', Turcica, 21-3.

Vaudeville, C., 1992, 'Govardhan, the Eater Hill', in R.S. McGregor (ed.), Devotional Literature in South Asia, Cambridge, Cambridge University Press.

Walter, C., 2003, The Warrior Saints in Byzantine Art and Tradition, Oxford, Oxford University Press.

Warren, M. 1999, Unravelling the Enigma: Shirdi Sai Baba in the Light of Sufism, Delhi, Sterling Publishers.

Wolper, E.S., 2000, 'Khidr, Elwan Celebi and the Conversion of Sacred Sanctuaries in Anatolia', Muslim World, 90, 3 and 4.

Wood, P., 1981, 'Vassal State in the Shadow of Empire: Palmer's Hyderabad, 1799-1867', unpubl. PhD thesis, University of Wisconsin-Madison. 


\section{INDEX}

'Abd Allāh Khwēshgī Qasūrī 19, 32, 70, 71, 169 n.112

'Abd al-Hakīm Lāhawrī 66

'Abd al-Hamīd Ma'sūm 'Alī Shāh 74

'Abd al-Jabbār Khān Malkāpūrī see Malkāpūrī

'Abd al-Latîf Shushtārī in his Tuhfat al-'álam 83

'Abd al-Qādir Jīlānī 87, 127

'Abd al-Qādir Sarwari 170 n.132

'Abd al-Rahmān ibn 'Abd al-Rahīm 21

'Abd al-Rahman Jāmī 29

'Abd al-Rahmān Sulamī 53

Abū 'Alā' Mawdūdī 115

Abū'l Fazl Sayyid Mahmūd Qādirī 180 n.34

Abū'l Hasan ibn Sayyid Muhyī al-dīn Bukhārī 69, 177 nn.79-81

Abū Sa 'ìd Mìrzā 106

Afghan/s: defeat of Marathas at Panipat 49; saints of Qasur in Punjab, lives of 32

Afghanistan 104

Āftäb-e-dakan 151, 152, 153, 154; Āftāb 181 n. 34, 182 nn.35, 37, 39, 45-6, 185 nn. 37-44, 194 nn.10-12

Afzal Bēg Qāqshāl Awrangābādī 21, 25, 66, 170 n.131; anthology of 24

Ahmad Khattū in Ahmadabad 73

Ahmad Shāh Abdālī's occupation of Delhi 49

Ahmad Sirhind $\overline{1}$ see Sirhind $\overline{1}$

Ahmad Yasawī 185 n.51

Ahrār, Khwāja 11, 53

Absan al-shamā'il of Kāmgār Khān 19, 20, $22,24,29,32,35,36,40,42,43,44$, 72, 153, 154, 166 n.19, 167 n.47, 170 nn.122, 124, 129, 134, 171 nn.139, 142, 150, 151, 152, 173 nn.172-4,182,
174 nn.196-7, 201, 204, 212-213, 222, 183 n.83, 185 n.47; audience of 44-5; circumstances of composition of 43; glimpses of Sufi life revealed in 42; group reading sessions in 39; warnings against converse with kings 38; see also Kāmgār Khān

Akbar Shah II 64

Akbbār al-Awliyā 32

'Alā al-dīn Ahmad Khān 109

'Alā' al-dīn Khiljīi (Khaljī) 16, 51, 75, 150

Allāh Bakhsh, Khwāja 95, 113

Allāh kē Hukam 138, 139

Altāf Husayn Hālī 94, 179 n.30

Amīn Allāh 89

Amjad Husayn 122, 182 n.64

anti-British propagandizing 104-5

antinomian dervishes see qalandar

Anwār-e-tajalliyāt of Muhammad Haydar 68-70

Arabic scholarship 122; in Awrangabad 71; and Islamic scholarship, promotion of 121

Arberry, A.J. 164 n.2

architecture/architectural: and narrative of sainthood, mirrored worlds of 156-7; presence of a shrine 155; of sainthood, creation of specialized 51

'Ārif al-dīn Balkhī 61

'Arūs-e-'irfān 33

Asad 'Alī Khān Tamannā 66

Āsaf Jāh dynasty 26; administration under Sālār Jang, reform of 107; autonomy in Deccan under Nizām al-Mulk 21; Awrangabad, literary scene in early 64-8; domains 49; governing class 59; Haydarabad, mulki ('local') versus ghayr-mulkī ('immigrant') controversy 87; 
Nizams of the Deccan 48; rule in the Deccan 131

$\bar{A}$ safnāma 82

Aslah al-dīn 112, 113

Aslāb-ye-akblāq $\bar{u}$ dīn ('The Improving of

Morals and Religion') 21

$\bar{A}$ thār al-sanādīd of Sayyid Ahmad Khān 93,

101, 132, 178 nn.26, 28, 180 n.45

Awadh 53; Shi'a Muslim state of 88

Awliyā Allāh, Urdu journal 140

Awrangabad: as centre of literary production in Persian and Urdu 4; city's elites 6; construction of two churches in 106; disintegration of 86 ; economia of city and its saints $77-81$; growth in population 136; Hindus 105; imperial Mughal elites 27; imperial patronage in 32; independence from British India 95; İrānī community 9; khanaqahs of city's Mughal Sufis 47; literary migrants 35; loss of former eminence, nineteenth century 85; migrant Central Asian community 43; modern industrialization in 107; Muslims, historical patrimony of 150; Naqshbandīs 18, 24, 29, 31, 34, $78,89,96$; poetic tradition 67; primary sacred tradition 54; productivity of writers in 32 ; re-foundation in 1092/1681 47; as regional capital under Āsaf Jāh rule 66; saints and British Empire 109; saints in the New India 134; shrines 159; suburbs 4; Sufi legacy 158; Sufis under early Āsaf Jāh rulers 53-5; Sufis, literary tradition of 23-45; texts, reading and writing in 39 ; texts, shrine architecture 36-7; Urdu learning 123

Awrangzeb 1, 35, 174 n.206; death 48; decree against Sirhindī's followers 18; imperial pride 38 ; mausoleum of wife of $1,2,88,90,150$; reaffirming status of Khuldabad shrines 37

'Aydarusī Sufis 145

Azizuddin Husain, S.M. 165 n.16

Baba Pir 182 n.38, 184 n.15

Babur 9, 38

Ba'd Bā’l-dīn 59

Bādshāh Sāhib 96

Bāhā' al-dīn Hasan 'Urūj see 'Urūj

Bahā' al-dīn Zakariyā 11

Bahadur Shah 16, 64, 94, 108
Bahmani rulers 135, 150

Bal Gangadhar Tilak 105

Banē Miyān 115, 116, 119, 124, 138, 139, 184 n.14

Banē Miyān Collection 181 n.32

Barakāt al-awliyā see Tadhkira-ye-buzurgān-eDakan Barakāt al-awliyā

Barēwlī movement 138, 140

Barkhwurdār, Khwājā 12

Beale, Thomas W. 94, 128, 166 n.21, 177 n.64, 179 n.29, 183 n.75

Beg, A.M. 167 nn. 48,50

Bhimsen 66, 168 n.71, 170 n.128, 173 n.188, 174 n.205

Bidar 5, 38, 50

Bijapur 5, 33, 50

Bilgrāmī 32, 35, 37, 46, 51, 59, 60, 61, $67,74,77,124,143,167$ n. 58, 60-2, 169 n.104, 171 n.152, 174 n.203, 178 n.105, 180 nn. 3-5; account, Shāh Palangpōsh in 78; career 77; Rawzat al-awliya 79,132 ; on rise of Marathas 76; works 75

Bilgrami, S.H. 165 n.8

Blunt, Wilfrid Scawen 135

British: armies of 48 ; community in Awrangabad 106; defeat of Nawwābs of Bengal at Plassey 49; destruction in Shahjahanabad 109; power, rise of 101 ; Resident in Haydarabad 83; strengthening presence in Haydarabad State 105

Bukhara 32

Burhān al-dīn Gharīb 36, 37, 91

Burton, Richard, Sir 90, 179 n.24

al-Būsīrī 151

Bustān-e-khayāl 67

Byzantium, warrior saints of 12

Cairo 28

Central Asian/s: lineage 18; military elites of the city 15; Panchakkī shrine's resident dervishes 62; patrons of Mughal and $\bar{A}$ saf Jāh power in Deccan 89

Central Provinces 135

Chamanistān-e-Shu'arā of Shafīq Awrangābādī 34

Chāndū Lāl 85

Chishtī 32, 173 n.177; circles in Delhi 28, 39; circles in North India 93; Nizām al-dīn 5; saints of Delhi 39, 98; saints of Gulbarga 39; saints at Khuldabad 47; 
Chishtī (Continued)

shrine of Gēsū Darāz at Gulbarga 30, 154; shrine of Qutb al-dīn in Delhi 30; shrines of Awrangabad 47; shrines, location of major 113; Sufism 22; Sufism, relocation of tradition of 50 ; tradition at Khuldabad 30; tradition of Sufism 147

Chishtiyya 5, 34; history of 29

Christian Armenian traders 2

commemorative texts (tadbkirāt) 7, 74 'concentration' (tawajjub), practice of 18 contraction ( $q a b z$ ) and expansion (bast), contrasting mystical states of 18

Court, H. 165 n.7

Crooke, W. 185 n.53

cult rivalries 154

Dakhani literature 123

Dakhani poetry 33, 46

Dārā Shikūh 10, 30; safīnat al-Awliyā 28

Dargāh Qulī Khān Sālār Jang 34, 59, 65, 66

Das, H. 166 nn. 4,10

Dawlatabad 50,118

Deccan: Chishtīs 23; multi-layered Islamic tradition 104; kingdoms at Bijapur or Golkonda 47; Mughal colonists and their $\bar{A}$ saf Jāh successors 47; Muslim culture 50; Muslim sultanate of Golkonda 20; pre-existing sacred Muslim geography 161

Delhi: as centre of literary patronage and production 4, 32-3, 64; center of northern authority over the Deccan 154; Chishtīs see Chishtīs; Khānum Bāzār 53

dervish/es 143, 161; antinomian or qalandar 14, 168 n.70; Central Asian and Hindustani 3; texts read by 41 ; sheltering and feeding of 118 ; warrior 12,13

Dhakā 68

Dhikr 162

dhikr-e-jabr 59

Diyānat Khān 8, 54, 55, 80, 98, 152,154

Fakhr al-dīn 20, 22, 23, 34, 43, 62, 63, 64, 92, 94, 96, 98, 111, 181 nn.17-18

Fakhr al-hasan 64

Fakhr al-tālibīn 64, 97
Fakbriyyat al-nizām 20, 64, 97, 170 n.128

Faq̄ir 162

Farīd al-dīn Ganj-e-shankar 172 n.157

Fatāwā-ye-'Álamgīrì 32, 65

Fatehpur Sikri 9

Fazīlat Jang 136

Fazl al-dīn 60

Fazlī 67

Fergusson, J. 182 n.54

Forster, E.M. 106, 120

French, armies of 48

George, V., King-Emperor 108

Gēsū Darāz of Gulbarga 22, 23, 53, 91, 150 ; book by 32; Chishtī shrine of 13,51

Ghālib 109, 110, 111, 112, 181 nn.14, 15, 182 n.61; relationship with Nasīr al-dān 95

Ghawth al-samdān̄ 66

al-Ghazālī 26

Ghāzì al-dīn Khān Firōz, Jang 5, 12, 15, 24, 26, 46, 73

Ghijdawan, Naqshbandī shrine-centre of 11

Ghulām Ahmad Kambal Pōsh 54

Ghulām 'Alī Qādirī 96, 97, 131, 171 n. 147,173 n. 177,180 n.34

Ghulām Chisht̄i 31

Ghulām Hasan 73

Ghulām Husayn Khān Jawhar 82

Ghulām Imām Khān 122, 182 n.64, 185 n.34

Ghulām Mahmūd 120, 141, 146

Ghulām Nasīr al-dīn 94, 109, 110

Ghulām Nūr 56

Ghulām Qutb al-dīn 92, 93, 94

Ghulām Rasūl Mehr 181 nn.14,15

Ghulām Sarwar Lāhawrī 129, 183 n.76; account of Nizām al-dīn 129; Khazīnat al-asfiyā 125

Gill, Robert, Major 120; on Panchakkī 120

Golkonda 50; escape of king Abū'l Hasan 165 n.4; Husayn Shāh Walī of 171 n.147; Mughal conquest of 20, 38, 47, 82; Qutb Shāh rulers of 82, 123

Gommans, J.J.L. 177 n.71

Gonnella, J. 173 n.179, 176 n.32, 183 n.78

Gordon, S. 176 n.49

Grant, James, Captain 83, 179 nn.4-6

Great Revolt of $1273 / 1857$ 84, 94, 96, 103, 104, 109, 112; effect on Bahadur 
Shah II and Nizām al-dīn's descendants in Delhi 110

Gulbarga 50; shrines of earlier Chishtī saints 16

Gul-e-'ajā'ib 66

Gul-e-Ra'nā 59, 66

Gulistān-e-Khuldābād 149

Gul Muhammad Ahmadpūrī 98, 100, 101, 171 n.147, 180 n.42; account of Nizām al-dīn 98, 100; Takmila 99, 101

Gulshan-e-'Ajāib 66

Gurg, Khwāja 16

Gwalior 48

Habīb al-Barāzikh 114

Habīb 'Ali Shāh Yār Khāh

Bahādur 114, 181 n.28

Habìb al-Tälibìn 114

Hādī Naqshbandi 167 n.56

Hadramawt 104

Hadrāmī Arabs 135

Hāfiz 'Alī Shāh 114

Hāfiz Shāh Muhammad Ibrāhīm 69

hagiographies: collective, of Deccan's saints

125; modern, of Awrangabad's saints 159

Al-Hāj Muhammad 'Abd al-Hayy

$185 \mathrm{nn} .31-2$

Hālāt-e-Hazrat Bābā Shāh Musāfir Sāhib, M.V. 165 n.15

Halläj's utterances 40

Hamīd Allāh 89

Hammāmī, bathhouse 9, 56

Hasan Abdal 11

Haydarabad/State 2, 49; administration 105; anti-British sentiments 104; coinage 108; council for Muslim Unity (Majlis-e-Ittibād al-Muslimīn) 135;

Dakhani Urdu 123; Department of Religious Affairs 116; Department of Religious Endowments 141; dissolution in 1367/1948 134; fall of 153 ; famine in 107; feudal system 134, 159; Hindus 134; history of 73 ; independence 134 ; independence from direct British rule 103; Islamic character of 106; literary primacy of 4; Muslim notables 105; Muslims 135; nationalists, mulk $\bar{\imath}$ sentiments of 130; North Indian administrators 108 ; surrender to rule by united and independent India 135; transfer of Āsaf Jāh capital to $67,73,82$ Haydar 'Alī, rise of 83
Herat 25, 29

Hidāyat al-rāmī 144

Hindu/s: domination of Haydarabad's trade 134; festivals of spring 157 ; kingdom of the Marathas 48; and Muslim devotees 140; revivalist organizations 135

Holland, John 83

Humayun's wife Hamīda 171 n.146

Husayn Shāh Walī of Golkonda 171 n. 147

Ibn 'Arabī 10, 57, 68; doctrines of 69

Ibn Maymūn 57

Ibrāhīm bin Adham 79

'Imād al-dīn Nehrī 86

'Imād al-Mulk Ghāzī al-dīn Khān Fīrōz Jang III 20, 64, 97, 98, 129, 170 n.128, $171 \mathrm{nn} .143,148,149176$ n.62, 179 nn.35-9; account of Nizām al-dīn 98; in Fakbriyyat al-nizām 101

Imām al-dīn Naqwī 125

Imāmbhāī Chōtā Khān 117

imperial geographies 27-35

'Ināyat Allāh, Naqshbandī 11, 12, 31, 54, 70,89 ; shrine of 145 ; lineage of 54

'Ināyat Allāh Khān Awrangābādī 10, 14

'Ināyat Darwīsh 8

India as sacred Islamic land 46

Indian Sufism: network 89; and precolonial social order 110; see also Sufism

India's independence 134, 135

Indo-Muslim societies: court life 108; cultural life, centres of 87 ; ethnicity in 129; history 100

Indore 48

Inshā-e-jur'at 66

Iran 104; revival of Sufism in 74

Islamic Culture 122

Islamic revival 130

Islamic Western Asia 31

Islam, K. 179 nn.31-2

Islam, localization of 46

Jabbar, M.A. 150, 182 n.57, 184 n.21

Ja'far Sharīf ('Jaffur Shurreef') 87, 179 n.12

Jahānārā, princess 33, 65; burial of 57

Jahangir 35

Jalalabad 12

Jalāl Khān Dāūdzā̄i 32 
Jalwa-e-d̄̄dār of Hazwar Muhammad 'Āqil 81

Jama'at-e-islāmī 115

Jamāl al-dīn 'al-Afghānī' 122

Jāmī 91, 172 n.158; Nafahāt al-uns 91

Jamīl Bēg Khān 66, 143

Jān Allāh Shāh 116

Jayaram, R. 180 nn.6, 7

Jaysinghpura 4

Jur'at Khān Mu'iz al-Dawla 66

Kabul 11

Kalīm Allāh Jahānābādī, Chishtī shaykh 6, 19, 20, 22, 25, 30, 38, 42, 53, 64, 109, 166 n.20, 169 n.110, 170 nn.119, 120, 171 n.145; khanaqah 109; work 22; see also Kashkūl-e-Kalīmī

Kamāl al-dīn 112

Kāmgār Khān 20, 22, 23, 24, 25, 32, 36, $38,40,43,54,63,65,66,113,130$, 166 n.19, 184 n.28; account of Nizām al-dīn 30, 42, 100, 147; close connection with Mughal state 25; journey to Delhi 25-6; literary efforts 42; see also Absan al-shama'il

Karshi 11

Kashkūl-e-kalīm $\bar{\imath}$ 22, 42

Kedar 82

Kewal Rām 166 n.28

Khāfī Khān 29, 166 n.28, 173 n.170; early history of Awrangzeb 152; Muntakhab al-Lubāb 27

Khāksār-e-Sabzawārī see Sabzawārī

khānaqāh (khānagāh) 8, 52, 162; complexes 51 ; details of life in 39; foundation of 52 ; reliance on aristocratic patronage 52

Khān-e-Khānān 'Abd al-Rahīm 9

Khātim-e-Sulaymāñ̄ of Mawlānā Allāh Bakhsh 169 n.117

Khazāna-ye-'ämira 51, 60, 75, 175 n.7, 176 nn.42, 45, $178 \mathrm{nn} .86-9$

Khazinnat al-asfiya 129,183 n.77

Khirki 1, 8

Khizān ü babār 56, 77

Khujista Bunyād 1

Khuldabad 5, 47, 50; Chishtī tradition at 30; shrine of Burhān al-dīn Gharīb at 61; shrines at 16,37, 54

Kìmiyā-ye-sa'ädat of al-Ghazālī 26, 42

Kirkpatrick, James Achilles 83

Kishan Parshād 116, 183 n.88
Kitāb hikmat al-ishrāq of Shihāb al-dīn Suhrawardī 70

Kubrāwiyya 12

Kurnul (Kurnool) 48

Lakshmī Narā'in Shafīq Awrangābādī 59, 66, 73, 82, $176 \mathrm{nn} .37,52-3,177 \mathrm{nn} .85$, 89; Gul-e-Ra'nā 71

Lālā Mansārām 28, 66, 68; account of Nizām al-Mulk 98

Lane-Smith, Henry, Rev. 108, 118 , $181 \mathrm{n} .12$

Light of Muhammad

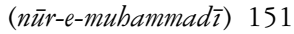

literary tradition: in age of empire 23-45; in early Āsaf Jāh Awrangabad 64-81; in new empire 96-102; in nineteenth century 121-33; in twentieth century Awrangabad 148-57 literature/literary: activity in Awrangabad, nineteenth century 121; celebrations of saints of Awrangabad 73; circles of Delhi 96; commemorations of Awrangabad's saints by Bilgrāmī Sabzawārī and 'Urūj 125; discrete traces of Deccan's political history 34; means of disseminating traditions of Muslim sainthood 148; scene in Awrangabad 34; separation of religous and political 27

Lucknow, literary primacy of 4

Ma'äthir al-kirām 32, 76, 78, 167 n.58, 60-2, 173 n.181, 178 n.102

Ma'àthir al-Umarā of Shāh Nawāz Khān 7, 9, 10, 34, 66, 166 nn.21, 29, 30, 36, 167 n. $4.42,45,46,175$ n.29, 176 n.108

Ma'āthir-e-Āsafì 82

Ma'āthire-e-'Álamgīin 13, 27, $166 \mathrm{n} .32$

Ma'āthir-e-Nizāmī 28, 68

Mackenzie, Colin, Major 85; survey of Deccan 85

madrasa 34, 118, 138

Maharashtra 136; formation of state of 155

Mahbūb 'Alī Khān 94, 106

Mahfil-e-samā' 162

Mahmūd Bahrī 173 nn.190, 191

Mahmūd ibn Amīr Walī 173 n.183

Mahrām 67 
Majālis-e-Kalīmō 25

Makbzan al-a'rās 10, 166 n.36, 176 n.31

Maktūbāt-e-mujaddid-e-alf-e-thān̄ $\bar{\imath}$ 91, 170 n.123, 173 nn.171, 176,

174 nn.199, 207

malfüzāt: genre of 23, 41; of Nizām al-dīn 24; and textual contemporaries in Awrangabad 28

Malfüzät-e-Naqshbandiyya 11, 13, 14, 15 , $17,21,23,32,36,59,65,72,73,78$, $120,142,143,144,150,151,162$, $165 \mathrm{nn} .15,16,166 \mathrm{nn} .17,18,27,31$, 36, 167 n. 58, 60-2, 168 nn.65-9, 74-6, 78-89, 171 n.136, 152, 172 nn.153, 154, 162, 165, 173 n.193, 174 nn.195, 200, 209-11, 216-19, 175 nn.10, 15, 16, 176 nn.103, 104; Central Asian character of the original fellowship of Awrangabad Naqshbandīs 24; composition of 19; description of reading group at Panchakki 40; great wealth of circumstantial details of khanaqah life 39; local readership in Awrangabad envisaged for 43-5; Persian as mother tongue of Central Asian subjects in 26; theory of Unity of Being (wabdat al-wujūd) 18

Malik 'Anbar 1, 8, 142, 163 n.2

Malik, Z. 171 n.147, 178 n.95

Malkāpūrī 116, 125, 133, 152, 153, 166 n.32, 171 n.144, 177 n. 68,183 n.7; account of Shāh Nūr by 127; narrative 128; on saintly sponsorship of Haydarabad's foundation 131; tadhkira of Deccan saints 114,144

Manāqib-e-Chishtiyya 26, $172 \mathrm{n} .157$

Manāqib-e-fakbiryya 64, 97

Man Lagan 33

Mānpūrī Parshād, Sadhu 10, 118, 156; religious songs (bhājānns) 118

Manucci, Niccolo 10, 165 n.4, 167 n.51, 173 n. 170

Marathas 82, 135; nationalism 105-6, 155; patronage of Sufi shrine 61; Pēshwā Bālàjī 48; rulers and notables, grants from 61; wars 3

Marathwada Waqf Board 137, 143

Mardum dīda 66

Massignon, L. 164 n.2

Mathnawī of Rūmī 39, 41, 71, 162

Mawlawī Ahmad 171 n.145
Mawlwī 'Abd al-Haqq 119, 123 , 182 n.65

Mawlwī Muhyī al-dīn 115

Maysur (Mysore) 48

Mazhar al-nūr of Qamar al-dīn 70

Miftāh al-ma'arif ('Key to the Ways of

Knowledge') 62

Mīr 'Abd al-Qādir 16

Mīr Fakhr al-dīn Tirmidhī 61

Mīr Muhammad Yūsuf 41

Mīr Sayyid Muhammad Qanawjī 13, 30, 172 n. 157

Mīr Shams al-dīn Faqīr Dihlawī 33

Mishkat al-anwār 70

Mishkat al-Nubuwwat 96, 97, 131

Miyān Dād Khān Sayyāh 121

Miyān Mīr Walī 183 n.87

Mīrzā 'Abd Allāh 112

Mìrzā Āghā Bēg 184 n.17

Mīr Zāhid Mullā Jalāl 56

Mīrzā Ibrāhīm 139

Mīrzā Mazhar Jā-e-Jānān 112

Mīrzā Muhammad Akhtar Dihlawī 110, $181 \mathrm{nn} .17-18,20$; work of 111

Mìrzā Turk 'Alī Bēg, with pen name Wāsil 21

Moti Karanjar 55

Mubāriz al-dīn Raf'at 142, 150, 179 n.17, $182 \mathrm{nn} .47,50,58,184$ n.23

Mubāriz Khān 96, 131

Mughalpura ('Mughal quarter') 4, 6

Mughals: Awrangabad 4, 31, 34, 47, 65; colonization 46, 47; conquest of Deccan and cultural changes 34, 130; conquest of independent Muslim sultanates of Deccan 46; dynasty, final dissolution of 103; elite of Delhi 93; in Herat and Central Asia, imperial origins of 29; royal house, biographies of Sufi saints 28; society, Central Asian (tūrān $\bar{\imath})$ and Iranian ( $\bar{r} r \bar{a} n \bar{\imath})$ factions in 24; Sufis 134; Sufi texts 38; Timurid world 29

Muhammad 'Abd al-Hayy 149

Muhammad Mazhar Nizāmī Chishtī Qādirī 184 n. 37

Muhammad 'Abd al-Rashīd Wahdatī 144,145

Muhammad 'Alī Khān 62

Muhammad 'Āqil 98

Muhammad A'zam Khan Banē Miyān see Banē Miyān

Muhammad Haydar 68-70, 177 nn.74-8 
Muhammad ibn 'Abd al-Rasūl al-Barzanj̄̄ 19

Muhammad Ikrām 8, 55, 166 n.32, 175 n.21

Muhammad Iqbāl 149

Muhammad Ismā̄ōl Shāh Qādrī, A'zam al-Karāmāt 182 nn.41, 49

Muhammad Kambakhsh 16

Muhammad Ma'sūm Naqshband̄̄ 73

Muhammad Miyān 147, 148

Muhammad Najīb Qādirī Nagawrī 167 n. 44,174 n.220

Muhammad Nūr al-dīn Husaynī 25

Muhammad Sulaymān 95; 'House of Learning' (dār al-'ulūm) 95

Muhȳ̄ al-dīn 140

Muhȳ̄ al-dīn Shamsī, of Haydarabad 139

Mu'īn al-dīn Chishtī 28, 30, 172 n.157; at Ajmer 136

Mu'iz al-dawla Jur'at 61

Mu'nis al-Arwāh 28

Mukarram Jah 148

Mukhtasar ma'ārij al-wilāya 19, 70, 169 n. 112

Muminabad, revolt in 84

Munshī Rām Singh 66

Munshī Sujān Rāī of Patiala 165 n.7

Muntajib al-dīn Zar Bakhsh 36

Muraqqa'-e-Diblī 59

Murīd wa murīdī 21

Murshid 162

Muslims/Muslim: anti-colonial movement 122; architecture in Deccan 46; architecture of memory 102; aristocracy of Delhi 64; authors in political service of Nizām al-Mulk 66; businessmen, local 138; citizens, relative impoverishment of 136; dependence on state 134; genesis of history in Deccan 50; Hindu groups competed for religious loyalties of people of state 130; of India and Islamic credentials of Indian homeland 46; literary rate 123 ; local pantheon of saints 155 ; massacres of 135 ; official character of state 106; population, overall proportion of 104; profession of faith 146; reformist movements 136; rulers in India, courts of 28; saints in other parts of world 129; territory, creation of new 157; upper classes of Awrangabad 43; Waqf Board 137

Must'ad Khān 13

Muzaffar Jang 48, 49
Nafahāt al-uns 29, 41, 75; see also Jāmī

Najīb Qādirī Nāgawrī Ajmērī 74

Naqshband, Khwāja 24

Naqshbandī/s: centre at Panchakkī 53; and Chishtī Sufis and Mughals, connections between 31; in Herat and Central Asia 39; khanaqah in Balapur 70; masters of Rai Bareli 14; meditation (khatm) 16; meditational chants (dhikr) 6;

Naqshbandiyya 5, saints of 28; practices, Central Asian character 18; saints 23; saints of Bukhara 39; Shāh Palangpōsh and Shāh Musāfir 5; shaykhs 7; Sufis 11-19; Sufism in Deccan, spread of 11; Sufism, vocabulary and practices of 18; tradition of loud chanting

(dbikr-e-bìl-jabr) 146

Naqshband̄̄-shādhilī Sufis 145

Naqwī 126, 129; on Nizām al-dīn 130; Urdu Barakāt al-awliyā 125

Nāsir al-Dawla Āsaf Jāh IV 84

Nasīr al-dīn Chirāgh-e-Dihlī 98

Nas̄ir al-dīn Hāshimī 173 n.189

Nasīr al-dīn Mahmūd 172 n.157

Nasīr al-dīn Nehrī 86

Nāsir Jang 23, 48, 71, 133, 149; death of 49

Nawāba Baìjī 166 n.33

Nawkhanda palace 17, 108

Nawwāb Mīr Ghulām Bābā Khān 121

Nehru's new national army in $1367 / 1948135$

Ni'mat Allahī brotherhood 5, 38, 74

Nizām al-'aqā'id 64

Nizām 'Alī Khān Āsaf Jāh 49, 54, 57, 60, $72,82,153,171$ n.140; treaty with the East India Company 84

Nizām al-dīn Awrangābādī 7, 19, 22, 23, 36, 37, 38, 46, 92-6, 98, 146, 147, 150, 166 n.20; architectural legacy of 54; biographer Kāmgār Khān 22, 59;

Chishtī heritage 37; connections with Delhi-centred tradition 97; in Delhi 30, 50 ; discourses on subject of mabfile-e-samā 22; dual heritage malf $\bar{u} z \bar{a} t$ 23; fame and spiritual power of 102; filial connections with Delhi 124; heirs 92; khalīfas 23; khanaqah 20-1; and lingering image of Nizāms 153-5; local preeminence 63 ; malf $\bar{u} z \bar{a} t$ of 24 ; musical sessions 40; as patron saint of Nizāms 148; origins in Awadh 30; 
pilgrimages 37 ; private-life 22; 'recorded conversations' (malfüzāt) 6, 20; relationship with Nizām al-Mulk 98, 101, 154; reputation 113; saint 93, 109, 148; sajjäda nashīns of 114; shrine in Awrangabad 62-4, 113; see also Nizām al-qulūb

Nizām al-qulüb 22, 41, 99, 100, 124, 165 n.2.

Nizām al-Mulk Āsaf Jāh, Nawwāb 4, 12 , $20,28,46,48,59,63,82,93,108,113$, $148,149,156,177$ n.73; death of 48 , 72 ; during reign of 51 ; formal Sufi initiation (bay'at) 20; governor (sübedār) of the Deccan 47; pen name of Khwāja 67 ; successors 48; successor state 131 ; territories 48

Nizāms 82; armies 104; British 'protection' 84; Minister for Religious Affairs

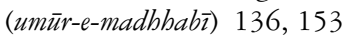

Nizām Shāh rulers of Ahmadnagar 1

Norris, William, Sir 3, 4, 165 n.4, 165 n.28

North Indian Muslims 108

Nür al-anwār 7, 166 nn.22-4, 26, 32, $167 \mathrm{nn} .41,43,175 \mathrm{nn} .18,23,29$, 175 nn.21, 25, 176 n.30, 178 nn.94, $110-20$

Nūr al-Hudā 71

Nür al-Karimatayn 70

Nūr Muhammad Mahārawī 64, 95, 98

oral hagiography and historical memory $155-7$

Oriental Biographical Dictionary 94, 128

Ouseley, William, Sir 165 n.5

Palmer, William 84, 85

Panchakkī 24, 36, 149-51, 162; building of 156; eighteenth-century 62; eponymous watermill 62; government claims to 142; income or 'gifts' (nadbrāna) to 61; landholdings, scale of 121; library 91, 144; saints of 58-62, 89, 119-21, 141-6; sajjäda nashīns of 92, 119; shaykhs 26; spiritual legacy of saints 146; wealth of 60

Panchakkī-ye-Awrangābād 142, 150

pan-Islamism 122; ideology 108

Pathan rulers of Kurnul 48
Persian: in Absan al-shamä'il 26; historians of Deccan 83; historiographical tradition in India 27; immigrants 6; learning 122; literature 27, 123; Sufi works 68

Pickthall, Marmaduke, translation of the Quran 122

pilgrimage guide to shrines of Awrangabad region 56

Political Survey of the Deccan 83

politics and patronage of praise 74-7

Poona 48

Prophetic Being (wujūd-e-nabī) 69

Punjabis 136

Qadh al-zand 19

Qādir Khān Munshī Bīdarī 73

Qalandar 14, 162

Qamar al-dīn 70, 71, 72, 167 n.56

Qanoon-e-Islam 87

Qasīda Burda Sharīf 151

Qaysar Miyān 113, 153

Qāzī Mahmūd Bahrī 33

Qāzī Muhammad Mas'ūd 8

Qāzī Tāqī Naqshbandī 144

Qillīch Khān see Nizām al-Mulk Āsaf Jāh, Nawwāb

Qizilbāsh Khān 33

Qutb al-dīn 55, 56, 109, 111

Qutb al-dīn Bakhtiyār Kākī 65, 172 n.157; medieval shrine of 111

Qutb Shāh rulers: in Haydarabad 49; of Golkonda 82

Rābi’a Dawrān̄̄, Awrangzeb's wife 90

Rahīm Bakhsh Fakhrī 64

Rājā Musāwir Jang 120

Rashabāt-e-'ayn al-hayāt of Kāshifi 172 n. 158

Rashk-e-Gulistān-e-Ibrām 20

Rawnaq 'Alī, Rawzat al-aqtāh 132, 133, 149, $183 \mathrm{nn} .89-93$

Rawzat al-Awliyā of Āzād Bilgrāmī 37, 75, 76, 178 n.107

Rawza-ye-sharī of Kishan Parshād 132

Raymond, Michel 83

razākārs or 'volunteers' 135, 162

religious nationalism among Hindus 135

Resident in Haydarabad 103

Revolt of 1273/1857 see Great Revolt

Revolt in $1268 / 185295$ 


\author{
Risāla-e-wālidiyya 11 \\ Risāla-ye-'aynak-e-Būqalmūn 69 \\ Risāla-ye-Sālār Jang (Muraqqa'-e-Dilhī ) \\ 34, 65 \\ Rohila Afghans 104
}

Sabzawārī, Khāksār 37, 54, 56, 60, 74, 77, 78, 139, 143, 164 n.1, 166 n.26, 169 n.125; account of Nizām al-dīn 63; accounts of Chishtī saints of Khuldabad 81; account of Shāh Nūr 81

Sa'd Allāh 55, 89, 91

Sādiq Isfahān̄̄ 1, 165 n.5

Sāi Bābā of Shirdi 117

saintly geographies 35-9

saint/s: of Awrangabad, texts praising 72; in Indian nation 136-48; and kings in

Urdu hagiographies 129; of

Naqshbandiyya 25; new form of patronage of 138; of Panchakkī 58-62, 89, 119-21, 141-6

sajjāda nashīns 52, 53, 89, 119, 162;

lineages 51, 54; role as professional mystics 59

Salābat Jang 48, 49, 69, 72

Sālār Jang 84, 134; family 57; reforms of 105

Salīm Chishtī in Fatehpur Sikri 73

Samarqand 32

Sambhājī, capture of 13

Sāqī Must'ad Khān 13, 27, 30, 166 n.32, 168 n.72-3, 174 n.205

Sawānih of Sabzawārī 37, 54, 78, 81, 166 n.36, 165 n.37, 170 n.125, 174 n.11, 175 nn.26, 28, 31, 176 nn.40-4, 43, 55-7, 60-1, 177 n.63, 178 nn.1, 121-3, 180 n.1, 183 n.1, 184 n.16

Sayf al-dīn 112, 138

Sayyid 'Abd Allāh ibn Abū 'Alā Hamadān̄̄ 9, 79

Sayyid 'Abd al-Qādir Mihrbān 61

Sayyid Abū'l Hasan 'Alī Nadw̄̄ 183 n.68

Sayyid Ahmad Khān, Sir 93, 101, 132, 170 n.118; and Aligarh Movement 122; $\bar{A}$ thār al-sanādīd 125

Sayyid 'Alī Sultān 12

Sayyid Hasan 147, 154, 171 n.144, 184 n.29, 185 nn.45-6, 48-9

Sayyid Imām al-dīn Naqwī Hanafī Gulshanābādī 183 nn.67, 69, 79-81

Sayyid M̄̄r 'Alawī 144
Sayyid Sharaf al-dīn Khān 66

Sayyid Shihāb al-dīn Qibla 167 n.43

Sayyid Wāsil 139

Seely, J.B. 85, 90, 179 nn.9, 14, 21, 23;

on Panchakkī 90, 91

sepoys' revolt see Great Revolt

Shafi'i, M. 173 n.180

Shafīq Awrangābād̄̄ see Lakshmī Narā'in

Shāh 'Abd al-Az̄̄z 64

Shābān-e-bè-tāj 149

Shah 'Alam 3, 64

Shāh 'Al̄̄ Nehrī 66, 118

Shāh Dawla 96

Shāh Ganj Market 20

Shāh Ghulām 'Al̄̄ Chisht̄̄ 77

Shāh Ghulām Husayn 67, 71; Naqshbandī lineage of 54

Shāh Hāfiz Allāh 91

Shāh Hamīd Allāh 119

Shahīd Mullā Bāqir 32, 61

Shāh Imām al-dīn 118

Shāh Ismāî̀l 31, 77

Shah Jahan 1; Friday Mosque in Delhi 171 n.145; reaffirming status of Khuldabad shrines 37

Shāh Khākī 34

Shāh Mahmūd Awrangābādī 17, 25, 27, 32, 35, 36, 38, 43, 54, 58, 59, 66, 165 n.15; author of Malfüzāt-e-

Naqsbbandiyya 24; hagiography of Shāh Musāfir and Shāh Pālangpōsh 19; see also Malfūzāt-e-Naqshbandiyya

Shāh Munīb Allāh 70

Shāh Musāfir 6, 7, 11-19, 23, 24, 39, 46, $58,121,156$; barakat of 59; education of 41; first sajjāda nashīn Shāh Mahmūd 141; mausoleum 60; pilgrimages 37; popularity of 144 ; relics of 143 ; as reliever of illness and misery 15 ; reputation 143; shrine of Panchakkī 126; see also Shāh Palangpōsh

Shāh Nawāz Khān 7, 57, 66, 74, 124, 166 n.21

Shāh Nūr 7-11, 19, 37, 55-8, 136-41; change and renewal in life of 151 ; cult of 115; emergence into saintly tadbkira tradition 78; as 'bammām saint' 56; identity, notions of 139; kin-name (nisba) 9; life by Bahā' al-dīn Hasan 'Urūj 7; literary silence in tadbkira tradition of 127; miracles 80; primary source of prestige 79; saint 115-18; shrine 54, 
88, 136, 156; tradition of friendship between Sufi and Sadhu, 140; twentieth century 139

Shāh Palangpōsh 7, 11-19, 23, 27, 39, 58, 73; education of 41; grave of 53; name as 'the wearer of leopard-skin' 13, 14; pilgrimages 37; and Shāh Musāfir, cult of 120; and Shāh Musāfir, embeddedness in social affairs of clientele 16; Shāh Musāfir's principal spiritual director (murshid) 12; see also Shāh Musāfir, Shāh Qutb al-dīn Qutb Hamawī 9 Shāh Sharīf al-dīn Qādirī 20, 63

Shāh Shīdā 34

Shāh Sulaymān Tawnsawī 94

Shāh Tajallī 'Alī 82

Shāh Walī Allāh 64, 87

Shāh Yūsuf al-dīn Qādirī 20

Shajarat al-anwar 64

Shakar Khera, battle at 131

Shams al-dīn Chishtī 115, 116, 152; death 137; family connections in Haydarabad 116; reputation 117; working in service of Shāh Nūr 116

Shams al-dīn Rafi' al-Darajāt 91

Shattārī 5

Shawq 57

Shihāb al-dīn Suhrawardī 55, 70, $102,128,129$

Shīh Kalīm Allāh 30

Shi ism/Shi' ite: clerics rise of 53; decline of official 27; in Persia 29

Shīr 'Alī Afsūs 3

Shīvājī and his antagonism towards Awrangzeb 155

shrine/s: of 'Abd al-Khalīq 167 n.53; of Bābā Qul Farīd 167 n.53; of Gēsū Darāz 135 ; income provided by land grants 51 ; of Khuldabad 21; of local importance in India and Pakistan 148; of Multānī Bādshāh 49; in Multan and Uchch in Pakistan 157; and pilgrimage in texts 35-9; of Qādir Awliyā 98; of Shāh Khāksār 78; of Shāh Nūr 55, 72, 104, 153; Sirāj al-dīn Husaynī 67; of Sirāj Junaydī 51; as store-houses of historical memory 87

Sikandar 'Alī Shāh 33

Sikandar Jāh 8

Sikandar Khān 33

Sirāj Awrangābādī 21, 65, 67, 169 n.132; biography 21
Sirhindī, Ahmad 11, 69, 70, 89, 91; banning of letters in Mughal domains 18; collected letters (maktūbāt) 18; doctrines, disavowal of 19; opponents 18

Society for the Promotion of Urdu

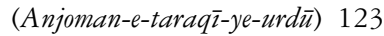

Subhat al-marjān 46, 177 n.83

Sufis: of Awrangabad 1, 51; of Delhi 98; of Khurasan 68; of late Mughal Awrangabad 6, 158, 160; of the north, spiritual conquests of 32

Sufism: in age of empire 4-7; biographical writing 100; and their books 39; and changing cultural landscape of the Deccan 49-53; circles of Delhi 95, 111; in Delhi 34; dichotomy of 'popular' and 'elite' 159; formulation on knowledge 40; foundations for new royal city 46-64; groups in Mughal Awrangabad 31; hagiographical tradition 38; hagiographies of Awrangabad's saints 159; holy men migrant from other regions of Islamic world 50; ideal of personal poverty (faqr) 16; initiations, multiple 6; initiate (murīd) 5; Khwānd Shāh Mu'īn al-dīn 42; lineage (silsila) 5; meditation (dhikr, murāqaba) 59; migrants in Awrangabad 31; milieux, textual authority 40; 'orders' (turuq) 5, 27; posthumous cults 160; reading circles in two Awrangabad malfüzāt 74; relationship with life in the world 158; risāla of theory 41; saints of Khuldabad 131; in shadow of a new empire 82 ; in social role 14; structures of hierarchy 40; tasawwuf 5; teaching, function of written material in premodern 39; teaching institutions across North India 95; texts in Urdu, composition of 124; tradition at work in Awrangabad 19; traditions of Haydarabad Deccan 117; travellers 65; works 91; writers of eighteenth century 68-74

Sydenham, G. 85, 179 n.10; report on shrine of Gēsū Darāz 85

Tabaqāt al-süfiyya of Sulamī 74

Tablīghī Jamā’at, Sufi-inspired missionary organization 126

Tadhkira-ye-Riyāz Husayn̄̄ 167 nn.48, 50, 170 n.130, 177 n.67 
Tadhkirat al-awliyā of 'Attār 40, 41

Tadhkirat al-shu'arā 77

Tadbkira-ye-awliyā-ye-dakan 127, 175 nn.17, 20, 24, 27, 177 nn.69-70, 82, 84-5, 90, 178 nn.91, 104, 181 n.28, 182 n. 43, 183 nn.72-4, 84-7

Tadbkira-ye-Awliyā-ye-Hind 110

Tadhikiral Tadbkirāt: 162; collections, typical 78 ; first generation of 74 ; reflection of specific affairs of social world 75; writers 34

Tadbkira-ye-buzurgān-e-Dakan Barakāt al-awliyā 126, 152, 162, 183 nn.67, 69, 79-81

Takmila-ye-siyar al-awliyā of Gul Muhammad Ahmadpūrī 93, 97, 125, $180 \mathrm{n} .43$

Tārikhb-e-dil afrüz 82

Tārìkh-e-Dilkūshā 66

Tārīkh-e-Khūrshīd Jāhī 150

Târikkh-e-mashä'ikh-e-Chisht ('History of the Shaykhs of Chisht') of K.A. Nizāmī 154

Tasnīm al-tawhīd 42

Tawāikh-e-farkbunda 73

Taylor, Meadows 88

Thevenot, J. de 2

Tīpū Sultān of Maysur 74, 83

Trimingham, J.S. 164 n.2, 176 n.33

Tubfat al-shu'arā 24, 25, 66

underground irrigation channels (nehrs) of Awrangabad 142

Unity of Being (wabdat al-wujüd), doctrine of the 68

Unity of Witnessing (wabdat al-shubüd) 69,70

Urdu 34; hagiography in changing environment 124-8; in Delhi and Lucknow, historic centres of 122 ; literary history 65; literature, foundation of 65; loss of influence to Marathi 136; rise in status of rēkbta 65; tadhkirāt 124, 125; transformation into sacred language of Muslims of South Asia 149

Urdū-e-mu'allā or 'Red Fort' 109

'Urs (pl. 'arās) 15, 21, 28, 37, 46, 56, 60, 81, 138, 139, 145, 148, 163, 174 n.1

'Urūj 9, 55, 56, 74, 75, 77, 153, 165 n.22; Babār u Khizān 78; emphasis on Shāh Nūr, arrival in Awrangabad 79; hagiography 80 ; tadhkira of Shāh Nūr 79

Usūl-e-naghmat-e-Āsafī of Ghulām Razā Khān 82

'Uthmān ‘Alī Khān, Nizam 108, 113

Valmīki 139

Wahābī Muslim propagandists in the state 105

Wahīda Nasīm 149, 185 n.30

Wā’ iz Kāshifī 29

Wal̄̄ Awrangābādī 4, 33, 65

warrior dervishes 12

Willmott, C. 165 n.8, 169 n.104, $180 \mathrm{nn} .3-5$

Yā Fatāh 121

Yahyā Madanī 19, 170 n.119

Yoga (baythak-e-jōg), benefits of postures of 22

Zahūr Khān Zahūr 166 n.22, $182 \mathrm{nn} .40-1$

Zakā Allāh 181 n.19

Zayn al-dīn Shīrāzī 28; shrine of 22

Zindaḡ̄ $\bar{u}$ Hālāt-e-Nizām al-dīn Awliyā Awrangābādì 153, 154 
eBooks - at www.eBookstore.tandf.co.uk

\section{A library at your fingertips!}

eBooks are electronic versions of printed books. You can store them on your PC/laptop or browse them online.

They have advantages for anyone needing rapid access to a wide variety of published, copyright information.

eBooks can help your research by enabling you to bookmark chapters, annotate text and use instant searches to find specific words or phrases. Several eBook files would fit on even a small laptop or PDA.

NEW: Save money by eSubscribing: cheap, online access to any eBook for as long as you need it.

\section{Annual subscription packages}

We now offer special low-cost bulk subscriptions to packages of eBooks in certain subject areas. These are available to libraries or to individuals.

For more information please contact webmaster.ebooks@tandf.co.uk

We're continually developing the eBook concept, so keep up to date by visiting the website. 


